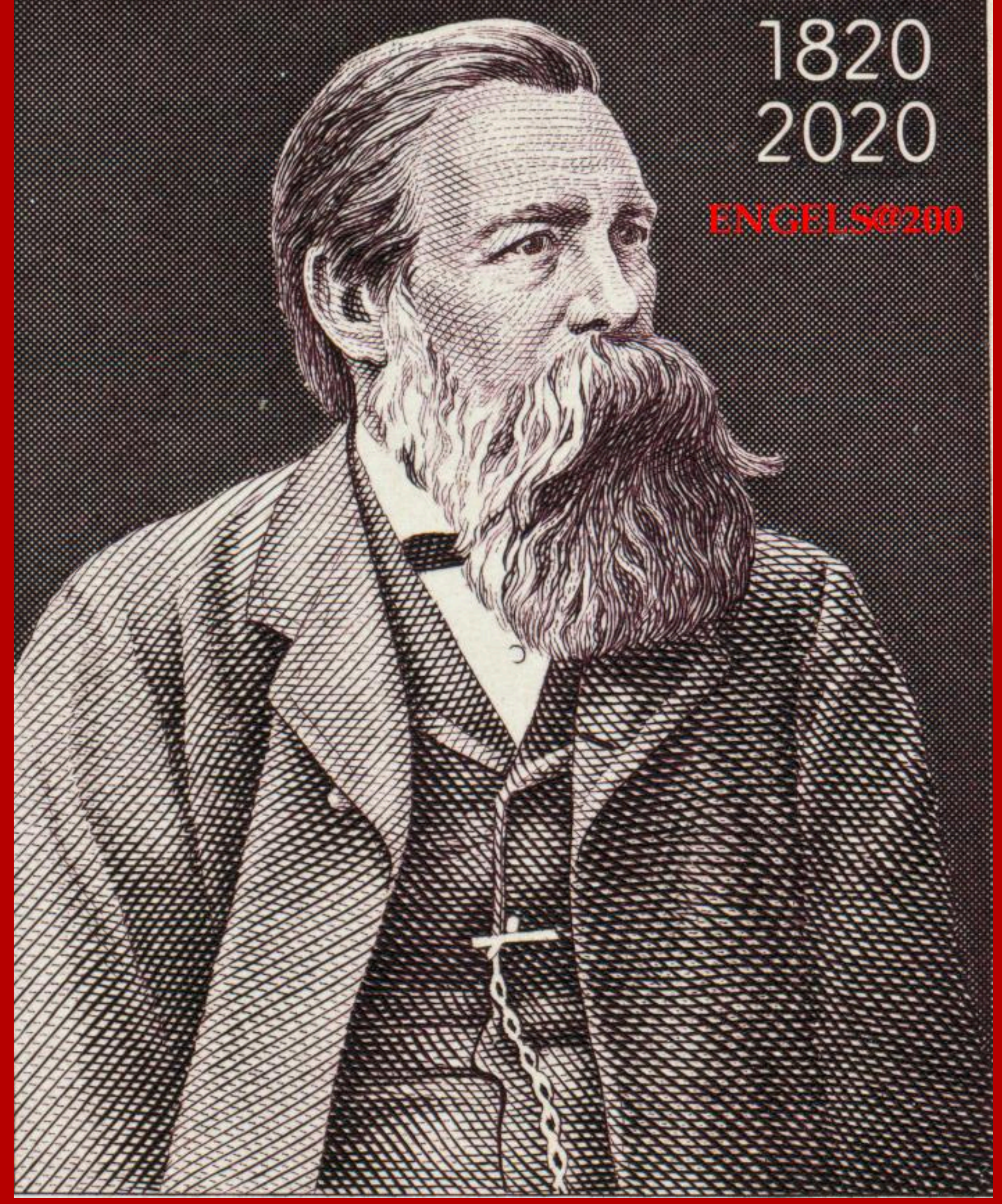

ENGELS@200: FRIEDRICH ENGELS IN THE

AGE OF DIGITAL CAPITALISM

Edited by Christian Fuchs 
Engels@200: Friedrich Engels in the Age of Digital Capitalism. Introduction. pp. 1-14 Christian Fuchs

Engels@200: Friedrich Engels and Digital Capitalism. How Relevant Are Engels's Works 200 Years After His Birth? pp. 15-51.

Christian Fuchs

Engels's Theory of Social Murder and the Spectacle of Fascism: A Critical

Enquiry into Digital Labour and its Alienation. pp. 52-67

Aishik Saha

Digital Capitalism and Coal Mine Workers. pp. 68-77

Akın Bakioğlu

Revisiting Friedrich Engels's Dialectics of Nature in an Age of Digital Idealism. pp. 78-96

Christopher Leslie

Break or Continuity? Friedrich Engels and the Critique of Digital Surveillance. pp. 97-112

Dimitrios Kivotidis

The Digital Economy of the Sourdough: Housewifisation and Exploitation as Self-Exploitation. pp. 113-124 Julianna Faludi and Michelle Crosby

On the Categories of Possibility, Limiting Conditions and the Qualitative Development Stages of Matter in the Thought of Friedrich Engels. pp. 125-139

Klaus Fuchs-Kittowski

Freedom, Distribution and Work from Home: Rereading Engels in the Time of the COVID-19-Pandemic. pp. 140-153

Saayan Chattopadhyay and Sushmita Pandit

The Conditions of the Global Digital Working Class: The Continuing Relevance of

Friedrich Engels to Theorising Platform Labour. pp. 154-170

Shahram Azhar

The Political Economy of Working-Class Social Media Commerce: Digital Capitalism and the Engelsian Concept of Working-Class "Property". pp. 171-194

Suddhabrata Deb Roy 


\section{triple C}

\section{Engels@200: Friedrich Engels in the Age of Digital Capitalism. Introduction.}

\section{Christian Fuchs}

University of Westminster, christian.fuchs@uti.at, http:/ / fuchs.uti.at, @fuchschristian

Abstract: This piece is the introduction to the special issue "Engels@200: Friedrich Engels in the Age of Digital Capitalism" that the journal tripleC: Communication, Capitalism \& Critique published on the occasion of Friedrich Engels's 200 th birthday on 28 November 2020. The introduction introduces Engels's life and works and gives an overview of the special issue's contributions.

Keywords: Friedrich Engels, $200^{\text {th }}$ birthday, anniversary, digital capitalism, Karl Marx

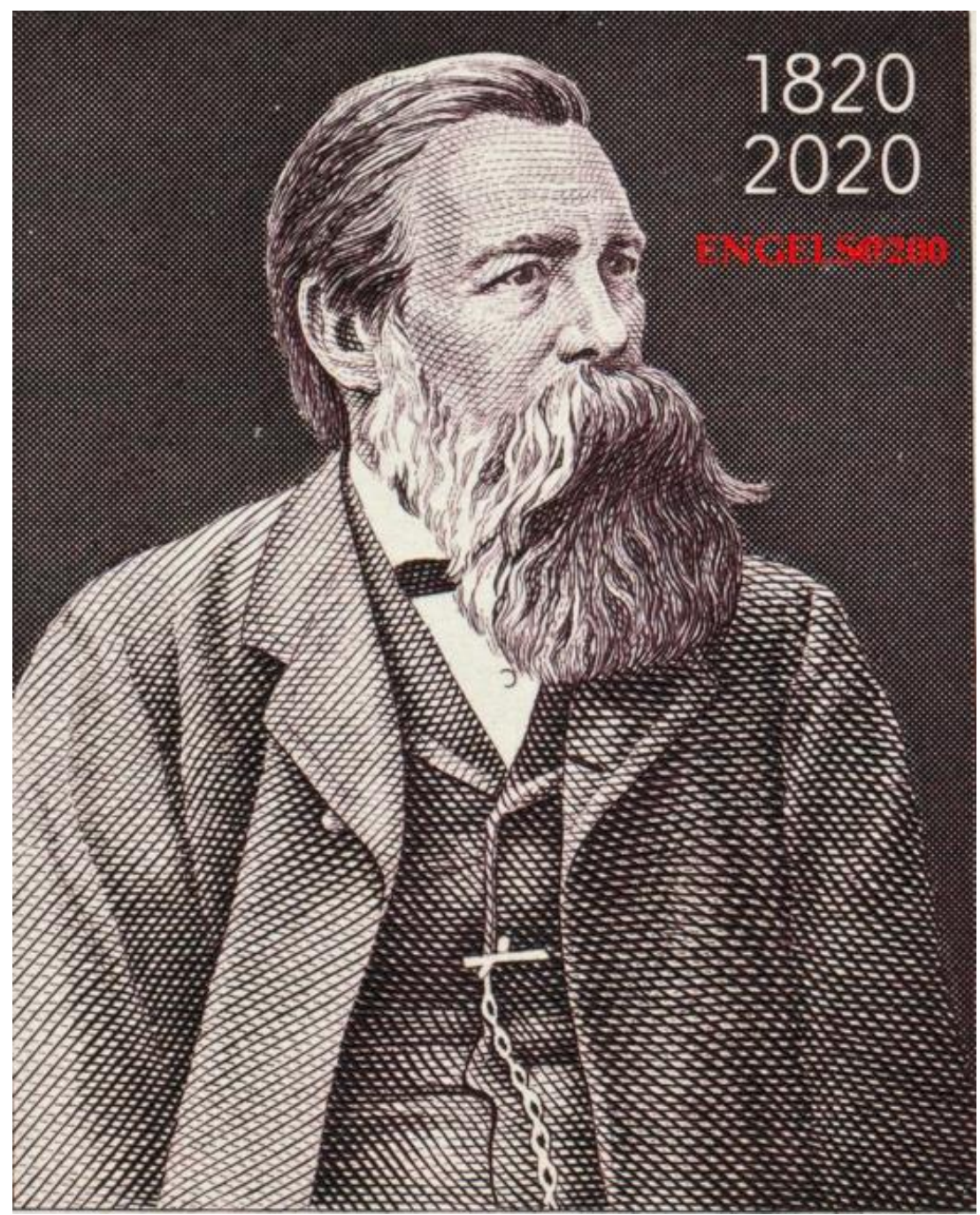




\section{Friedrich Engels's Life}

Friedrich Engels was born on 28 November 1820 in Barmen, a city in North RhineWestphalia, Germany, that has since 1929 formed a district of the city Wuppertal. In the early $19^{\text {th }}$ century, Barmen was one of the most important manufacturing centres in the German-speaking world. He was the child of Elisabeth Franziska Mauritia Engels (1797-1873) and Friedrich Engels senior (1796-1860). The Engels family was part of the capitalist class and operated a business in the cotton manufacturing industry, which was one of the most important industries. In 1837, Engels senior created a business partnership with Peter Ermen called Ermen \& Engels. The company operated cotton mills in Manchester (Great Britain) and Engelskirchen (Germany).

Other than Marx, Engels did not attend university because his father wanted him to join the family business so that Engels junior already at the age of 16 started an apprenticeship in commerce.

Starting in September 1841, Friedrich Engels for one year served as a one-year volunteer soldier in the Prussian Army in Berlin. During this time, he attended lectures by Schelling, who held Hegel's philosophy chair. Like Marx, Engels became a "Young Hegelian", which was the name used for the followers of Hegel's philosophy who provided a left-wing interpretation of this approach.

From late 1842 until summer 1844 he stayed in Manchester in order to work in his father's business. During this stay, Engels conducted research for his book The Condition of the Working Class in England (Engels 1845b), built contacts to the League of the Just and the Chartist Movement, and met the Irish worker Mary Burns. Mary Burns (1821-1863) was Engels's partner until her death in 1863. After Mary's death, Friedrich Engels lived together in a partnership with her younger sister Lydia ("Lizzy", 18271878), whom he married one day before her death.

Marx and Engels first met in 1842. They became life-long friends, comrades, and collaborators when they again met for a ten-day period in Paris in August 1844. In 1847, Marx and Engels joined the League of the Just that was renamed to Communist League that commissioned the two thinkers to write the Manifesto of the Communist Party.

During the revolutionary times of $1848 / 1849$, Engels contributed as journalist to the Neue Rheinische Zeitung, a radical democratic newspaper opposed to the monarchy and feudalism that was edited by Marx in Cologne. Engels actively participated in the revolutionary uprising against the Prussian regime in Elberfeld and Baden. After the defeat of the democratic revolution, Marx and Engels fled to England, where Engels started working for his father's company in 1850. He took over his father's management role in 1864. Engels junior hated work for the company because he did not share the capitalist worldview of the bourgeoisie. He saw the role as a strategic opportunity that allowed him to earn enough money for being able to fund Marx's research time and the socialist movement. In 1869, Engels left the company and the payout he received from selling his company share allowed him to fund his and Marx's work and the socialist movement until his death. He from then on dedicated his time to the socialist cause and socialist research.

In 1870, Engels moved to London so that he lived closer to Marx. Also in 1870, he became a member of the council of the First International (International Workingmen's Association). After Marx's death in 1883, Engels became the intellectual leader of the international communist movement. Given that Engels and Marx's daughters Eleanor and Laura were after Marx' deaths the only people alive who were able to read Marx's terrible handwriting, Engels devoted the majority of his time to editing volumes 2 and 
3 of Capital. Volume 2 was first published in 1885 and in a second edition in 1893. Volume. 3 was first published in 1894. Capital's first volume had been published in 1867 and its second edition in 1872/1873. The French translation that contained many important editorial changes made by Marx had been published in 1875 . Engels edited and published Volume 1's third (1883) and fourth (1890) German editions as well as the first English translation that was published in 1886/1887. Marxist and non-Marxist critics of Engels often point out that Engels' editorial work vulgarised and distorted the meaning of Marx's Capital. But there is little evidence that Engels' additions and changes resulted in substantial changes of the meaning of what Marx wrote down in the manuscripts of Capital (see Fülberth 2020; Hecker 2018, 52-66, especially 64-66; Kopf 2017, 106-107). Without Engels's editorial work, there would be no second and third volume of Capital. Engels improved the readability of Capital Volume 2 and 3 but did not change the theoretical meanings at the semantic level.

If Engels [...] had committed forgeries, for example in the third volume of 'Capital', then the first publication in 1992 of Marx's main manuscript from the third rough draft of the 'Critique of Political Economy' in MEGA2 Volume II/4.2 should have triggered a great flood of new, better solutions or presentations. But they do not exist, although more than two decades have passed. [...] Without Engels' great theoretical and methodological abilities, Marx would be a forgotten among other writers of the 19th century. Thanks to Engels, Marx's 'Capital' lives on in human memory throughout the centuries! (Kopf 2017, 106-107, 109, translation from German).

Suffering from cancer of the throat, Friedrich Engels died aged at the age of 74 on 5 August 1895.

\section{Friedrich Engels's Work and Works}

Engels on the one hand was the organiser and "manager" of Marx's intellectual works. On the other hand, he himself made important intellectual contributions to socialist theory. Engels together with Marx wrote the Manifesto of the Communist Party, The German Ideology, and The Holy Family. Engels also helped out Marx with writing newspaper articles that appeared under Marx's name. And he made a genuine contribution to critical theory with works such as Anti-Schelling (Schelling and Revelation), Outlines of a Critique of Political Economy, The Condition of the Working Class in England, The Housing Question, Anti-Dühring, Socialism: Utopian and Scientific, Dialectics of Nature; The Origin of the Family, Private Property and the State; Ludwig Feuerbach and the End of Classical German Philosophy.

At the age of 19, Engels (1839) published Letters from Wuppertal that documented the conditions the working class in Germany. Attending Schelling's lectures in Berlin, Engels published a series of three philosophical works that criticised Schelling's approach and defended Hegel against Schelling: Schelling on Hegel (Engels 1841), Schelling and Revelation: Critique of the Latest Attempt of Reaction against the Free Philosophy (Engels 1842a), Schelling, Philosopher in Christ (Engels 1842b). In 1843, Engels (1843) published the essay Outlines of a Critique of Political Economy, a foundational text of Marx's and Engels's approach to and critique of political economy, in which he formulated a critique of classical political economy. Marx $(1859,264)$ characterised the Outlines as "brilliant essay on the critique of economic categories" and directly referred to it several times in Capital Volume I (Marx 1867, 168 [footnote 30], 253 [footnote 5], 266-267 [footnote 20], 788 [footnote 15]). Michael Roberts $(2020,29)$ 
characterises the Outlines as "the first pioneering work of what we now call Marxian economics", where for the first time foundations of a Maxist theory of value were formulated.

Marx and Engels first joint works were The Holy Family, or Critique of Critical Criticism. Against Bruno Bauer and Company (Marx and Engels 1845) and The German Ideology. Critique of Modern German Philosophy According to Its Representatives Feuerbach, B. Bauer and Stirner, and of German Socialism According to Its Various Prophets (Marx and Engels 1845/1846). They wrote these manuscripts as a clarification of their own position towards contemporary German philosophy. Marx wrote the vast part of The Holy Family, but the book just like The German Ideology emerged from the joint thinking and discussions of Marx and Engels. The overall goal of both works was a critique of the contemporary left-wing thought of the 1840s as too much focused on the critique of ideas and religion. Marx and Engels argued for developing leftist critique towards a critique of capitalism and in doing so created foundations of a critical theory of ideology, capitalism, and communism. They focused their critique on the approaches of Carl Reichardt, Jules Faucher, Ernst Jungnitz, Edgar Bauer, Franz Zychlin von Zychlinski ("Szeliga”), Bruno Bauer, Ludwig Feuerbach, Max Stirner, Karl Grün, and Georg Kuhlmann. Holy Family was published as book in 1845. Marx and Engels did not find a publisher for German Ideology. The entire book was first published in 1932 as part of the first German Marx-Engels-Gesamtausgabe (MEGA ${ }^{1}$ ).

In February 1845, Engels (1845a) gave two speeches in Elberfeld as part of communist gatherings led by Moses Hess, who was Germany's leading communist in the 1830 s and 1840s and had major influence on Marx and Engels. Engels spoke about how communism differs from capitalism.

Engels conducted the research for his book The Condition of the Working Class in England $(C W C E=$ Engels 1845b) during his stay in Manchester from 1842 until 1844, where he was supposed to learn his father's trade. Engels directly experienced the working class' conditions in England and got in touch with workers, from whom he learned about their everyday life and the problems they faced. In CWCE, Engels analyses the rise, early development and consequences of capitalism in England. The decisive features he mentions are a) the working class, b) industrial technologies such as the steam-engine as moving technology and manufacturing machinery as working technology that replaced handicraft, c) the capitalist class, and d) the division of labour.

In CWCE, Engels analyses the terrible conditions that the working class had to endure in industrial England, including long working hours, low wages, poverty, overcrowded and dirty slums and dwellings, poisonous and uneatable food, overwork, starvation, death by hunger, lack of sleep, air pollution, untreated illnesses, egotism and moral indifference, crime, alcoholism, bad clothes, unemployment, rape, homelessness, lack of clean water, drainage and sanitation, illiteracy, child labour, military drill in factories, overseers' flogging and maltreatment of workers, deadly work accidents, fines, etc.

Using factory inspectors' reports, parliamentary reports, observation, and the analysis of news reports, The Condition of the Working Class in England shows that Engels already in the 1840s practiced and pioneered empirical social research (Kurz 2020, 67; Krätke 2020, 29-34; Zimmermann 2020). In Capital Volume 1, Marx (1867) uses the same empirical method as Engels in CWCE, which shows that Engels's work had large influence on Marx. Marx (1867, 349 (footnote 15), 573, 755) explicitly refers positively to Engels's book several times. Working on Capital, Marx re-read Engels's Condition and wrote to him about the book: "With what zest and passion, what boldness of 
vision and absence of all learned or scientific reservations, the subject is still attacked in these pages!" (Marx 1863, 469).

Marx and Engels' (1848) Manifesto of the Communist Party has been their most influential work. Published on the eve of the 1848 revolutions, the Manifesto outlines the critique of class society and capitalism, introduces different forms of socialism and introduces foundations of communism. Draft of a Communist Confession of Faith (Engels 1847a) and Principles of Communism (Engels 1847b) were pre-works and drafts written by Engels that Marx used as foundations for writing the text of the Manifesto (Marx and Engels 1848). Eric Hobsbawm (2011) writes that the Manifesto "was almost certainly by far the most influential single piece of political writing since the French Revolutionary Declaration of the Rights of Man and Citizen" (102) and that it "still has plenty to say to the world in the twenty-first century" (107).

Engels specialised on and over the course of his life again and again wrote about wars and military strategy. Examples are his works The Peasant War in Germany (Engels 1850), Po and Rhine (Engels 1859), Notes on the War (Engels 1870/1871), or Can Europe Disarm? (Engels 1893). At the end of his life, Engels anticipated the First World War and stressed the need for general disarmament as potential way out. "For the past twenty-five years all Europe has been arming on a hitherto unprecedented scale. Every major power is seeking to surpass another in military might and readiness for war. [...] Is there no way out of this blind alley except through a war of destruction such as the world has never seen? I maintain: disarmament and thus a guarantee of peace is possible" (Engels 1893, 372).

In The Housing Question, Engels (1872) criticised Pierre-Joseph Proudhon's approach to social policy and pointed out that the housing problem that the working-class faces is inherent to capitalism. Almost 150 years later, housing remains a key problem of capitalism as the financialisation of housing and its role in the 2008 capitalist crisis showed.

In 1878, Engels (1878) published Anti-Dühring. Herr Eugen Dühring's Revolution in Science. Eugen Dühring (1833-1921) was a German theorist who was influential in the Social Democratic Workers' Party of Germany, critical of Marx, and embraced positivism, anti-Semitism, and racism. In Anti-Dühring, Engels outlines foundations of dialectical-materialist philosophy, the critique of political economy, and socialism. Marx wrote the tenth chapter of the books' part on political economy. Parts of Anti-Dühring that focused on utopian socialism, dialectics, and historical materialism were first published (in French) in 1880 under the title Socialism: Utopian and Scientific (Engels $1880)$. In the 1870s and 1880s, Engels worked on materials about the dialectics of nature. The work remained unfinished and was first published in 1925 under the title Dialectics of Nature (Engels 1925). In 1886, Engels (1888) published Ludwig Feuerbach and the End of Classical German Philosophy in the socialist journal Die Neue Zeit. In 1888, the work was published as a separate book.

Lenin $(1913,24)$ characterised Engels's Ludwig Feuerbach and Anti-Dühring as "handbooks for every class-conscious worker". In the Soviet Union and in orthodox communist parties and movements, reading these works by Engels often was a substitute for engaging with Marx's writings and the entire oeuvre of Marx and Engels. Stalinism eulogised elements from some of Engels's works. In his essay "Dialectical and Historical Materialism" published in the History of the Communist Party of the Soviet Union Bolsheviks: Short Course - the ideological bible of Stalinism -, Stalin (1945) references and quotes from Engels's Anti-Dühring, Dialectics of Nature, and Feuerbach and the End of Classical German Philosophy. 
For Stalin, socialism as science does not mean a science of society that is different from the natural sciences, but deterministic and mechanical social laws of nature operating in society. The implication is for Stalin that history develops in a linear manner, it is for him a "process of development from the lower to the higher" (Stalin 1939, 109). Stalin argues that the Soviet Union followed capitalism and therefore was a socialist system: "[T]he U.S.S.R. has already done away with capitalism and has set up a Socialist system" (Stalin 1945, 119). His implication was that anyone critical of him was bourgeois and anti-socialist. The mechanical interpretation of the dialectic legitimated Stalin's terror against his opponents.

The concepts of Aufhebung (sublation) and the negation of the negation are missing in Stalinist dialectics. They are however key features of Engels's dialectics. Stalin referred to Engels, but Engels's interpretation of dialectics was other than Stalin's not based on mechanical and deterministic concepts. Engels is not be blamed for Stalinism (see Liedman 2018 , 467-525). For Engels, dialectics operates in nature, consciousness, and society. These dialectics are connected but not the same. In society, there are conscious human actors who act and struggle based on intentions and interests that cannot always be realised as planned because society is complex and dynamic. For Engels just like for Marx, history is the history of class struggles. "In modern history at least it is, therefore, proved that all political struggles are class struggles, and all class struggles for emancipation, despite their necessarily political form - for every class struggle is a political struggle - turn ultimately on the question of economic emancipation“ (Engels 1888, 387-388, 391). Scientific socialism does not mean for Engels that society develops based on natural laws and mechanical determinism. Rather, society has its own dialectical logic. It is one of the laws of society that change happens through human practices and that in class society, class struggle is the decisive practice of transformation.

The operation of dialectics in nature means that nature has the capacity to produce itself - nature is a complex, dynamic, self-producing system (Fuchs 2003). In society, the dynamic character of production is based on conscious, social actions of human beings who are producing, social, conscious, thinking, creative, moral, anticipatoryimaginative (i.e. capable of imagining the future and acting based on such anticipations) beings. Society is based on a dialectic of human practices and structures, in which human processes of social production play a key role. The dialectic of production and communication is another dialectic through which humans shape society (Fuchs 2020). Humans engage in a metabolism with nature, which means that there is a nature-society-dialectic (Fuchs 2006), where humans live based on nature and shape and transform nature. The specific dialectics that are at play in society include the dialectic of human practices and social structures, the dialectic of production and communication, the dialectic of nature and society, and the dialectic of human freedom and structural necessity/conditioning. Society and humanity are a particular form of the existence of matter that have their own, specific manifestation of dialectical principles with emergent qualities. Society and human beings cannot be reduced to nature. They are part of nature and have emergent qualities. Society is a sublation (Aufhebung) of nature (Fuchs 2006).

Elmar Altvater $(2015 ; 2016,150)$ argues that Engels' dialectical approach to nature and society anticipated red-green socialist thought. What Altvater and others term the Capitalocene, the subsumption of nature under capital, Engels (1925) reminds us, only appears as "human victories over nature" (460) in the first place, but in the "second and third places [...] has quite different, unforeseen effects which only too often cancel 
the first" (461). The climate crisis is such an unforeseen, negative effect of the Capitalocene that reminds us of the circumstance that humans "by no means rule over nature like a conqueror over a foreign people, like someone standing outside nature - but that we, with flesh, blood and brain, belong to nature, and exist in its midst " (Engels 1925, 461).

Engels also conducted multiple historical studies. We can just mention two of them. In On the History of Early Christianity, Engels (1894) analysed early Christianity as a movement of the oppressed, including slaves and the poor, and draws parallels to the modern working-class movement. In his book The Origin of the Family, Private Property and the State that was first published in 1884, Engels (1891) analyses the history and historical origins of the family, class, and the state. He based his analysis on the studies of the American anthropologist Lewis H. Morgan. Engels $(1891,131)$ argues that according "to the materialist conception, the determining factor in history is, in the last resort, the production and reproduction of immediate life", that reproduction such as housework is an important aspect of the economy and material life, and that patriarchy was history's first class relation:

In an old unpublished manuscript, the work of Marx and myself in 1846, I find the following: 'The first division of labour is that between man and woman for child breeding'. And today I can add: The first class antithesis which appears in history coincides with the development of the antagonism between man and woman in monogamian marriage, and the first class oppression with that of the female sex by the male" (Engels 1891, 173).

\begin{tabular}{|c|c|c|}
\hline Language & Marx's original manuscript & Engels' 1894 edition \\
\hline German original & $\begin{array}{l}\text { "[ [...] Dieser Proceß würde } \\
\text { bald die capitalistische } \\
\text { Production zum Klappen } \\
\text { bringen, wenn nicht } \\
\text { widerstrebende Tendenzen } \\
\text { beständig } \\
\text { wieder decentralisirend neben } \\
\text { der centripetalen Kraft } \\
\text { wirkten.)" (Marx 1863-1865a, } \\
\text { 315). }\end{array}$ & $\begin{array}{l}\text { "Dieser Prozeß würde bald die } \\
\text { kapitalistische Produktion zum } \\
\text { Zusammenbruch bringen, } \\
\text { wenn nicht widerstrebende } \\
\text { Tendenzen beständig wieder } \\
\text { dezentralisierend neben der } \\
\text { zentripetalen Kraft wirkten” } \\
\text { (Marx 1894a, 256). }\end{array}$ \\
\hline English translation & $\begin{array}{l}\text { "This process of divorce of the } \\
\text { conditions of labour from the } \\
\text { producers (which would soon } \\
\text { shake capitalist production if } \\
\text { counteracting tendencies were } \\
\text { not constantly at work along- } \\
\text { side this centripetal force, in } \\
\text { the direction of decentralisa- } \\
\text { tion)" (Marx 1863-1865b, 350) }\end{array}$ & $\begin{array}{l}\text { "This process would soon bring } \\
\text { about the collapse of capitalist } \\
\text { production if it were not for } \\
\text { counteracting tendencies, } \\
\text { which have a continuous de- } \\
\text { centralising effect alongside the } \\
\text { centripetal one". (Marx 1894b, } \\
\text { 245). } \\
\text { "This process would entail the } \\
\text { rapid breakdown of capitalist } \\
\text { production, if counter acting } \\
\text { tendencies were not constantly } \\
\text { at work alongside this centripe- } \\
\text { tal force, in the direction of de- } \\
\text { centralization (Marx 1894c, } \\
355 \text { ). }\end{array}$ \\
\hline
\end{tabular}

Table 1: A passage from Capital Volume 3 about the tendential fall in the rate of profit 
Engels's analysis of patriarchy has been influential on and led to discussions in Marxist and socialist feminism (e.g. Barrett 1980, 48-49, 131-132; Eisenstein 1979; Federici 2012, 1; Fraser and Jaeggi 2018, 32; Gimenez 1987; Haug 2015; Leacock 2008, 13 29; Notz 2020; Rowbotham 1973, 47; Sayers, Evans and Redclift 1987; Vogel 1996).

Without Engels' editorial work there would be no second and third volume of Capital. Engels was one of the few people who was able to read Marx's terrible handwriting. After Marx's death in 1883, Engels spent the last twelve years of his own life on editing Marx's manuscripts, which resulted in volumes two and three of Capital.

Some observers and analysts claim that Engels vulgarised Marx's works and distorted the content of Marx's original manuscripts. Two examples follow that refer to a passage in chapter 15 of Capital Volume 3, where we find a discussion of the internal contradictions of the tendency of the rate of profit to fall. Table 1 shows the German and English versions of this passage and both what Marx's wrote in the original German manuscript and Engels's version of it. The passage focuses on the impacts of the tendency of the rate of profit to fall on capitalist production and the role of the countervailing tendencies that are discussed in chapter 14.

Michael Heinrich's analysis of this passage is the first example. Carl-Erich Vollgraf's and Jürgen Jungnickel's analysis is the second example. Heinrich is a representative of the Neue Marx-Lektüre approach (New Marx Reading) that goes back to the works of Helmut Reichelt and Hans-Georg Backhaus, Vollgraf and Jungnickel are two of the editors of the second Marx/Engels Gesamtausgabe $\left(M E G A^{2}\right)$.

Authors such as Backhaus (1997) argue that Engels in his preface to and materials accompanying the third volume of Capital argues incorrectly that Marx in the chapter 1.3's value form analysis describe a historical development from simple commodity production to capitalism (for this discussion, see also Hecker 2018, 189-206). In reality, Marx would have provided an analysis of the logic of capital. Engels' misunderstanding would have grounded an evolutionary and mechanistic interpretation of Marx typical for Soviet Marxism, in which the identity of the historical and the logical moment of capital(ism) implies that the crisis-ridden nature of capitalism that is part of its antagonistic logic results in its natural law-like historical breakdown and the rise of communism. Marx certainly provides an analysis of capital(ism)'s dialectical logic, but he sees capital as historical system whose development is shaped by praxis, many historical examples form part of the analysis (see also Haug 2003). Engels's interpretation in prefaces and accompanying materials do not imply that he is the inventor of Stalinist and revisionist evolutionism.

Heinrich (2006, 360, footnote 55), argues that Engels' substitution of the term „Klappen” (folding) by „Zusammenbruch” (breakdown, collapse) enabled Henryk Grossman and others to claim that Marx saw "immanent breakdown tendencies" (translation from German) of capitalism. Heinrich (2006, 359 [translation from German]) writes that Engels "exacerbated” (,verschärft”) Marx's formulations. Vollgraf and Jungnickel (2002, 62), in a manner comparable to Heinrich, claim:

One word correction by Engels had a big effect on the reception. In discussing the tendency of the rate of profit to fall, Marx had stated in parentheses that centralization would cause capitalist production to 'shake,' if there were no countervailing effects. Engels, who as mentioned broke Marx's continuous exposition into subsections, removed these parentheses, made the idea the final sentence of the introductory subpoint he titled '1. General,' and replaced 'shake' with 'collapse,' with an eye to his own purposes. By just this one editorial intervention, 
Engels probably gave sustenance (e.g., with Bebel) to the breakdown expectations widespread in the Second International (as in Kautsky), and also gave a boost to the debate over whether Marx had a breakdown theory.

The English translations are somewhat imprecise. In fact, the only changes that Engels made are that he removed the parenthesis and substituted the German term "Klappen” by "Zusammenbruch”. The English translation of „Klappen” as "shake” is imprecise. According to the Oxford English Dictionary German/English, the precise translation is "to fold"1. Marx probably had the English term "folding" or "collapse" in mind when writing the sentence in question and translated it as „Klappen”. But in German to speak of "Klappen” of a system is very uncommon, which is why Engels seems to have used the more common term „Zusammenbruch”. "Engels thus replaced a rather colloquial expression from oral language ('Klappen') - which even today would seem strange e.g. in a scientific text - by a more term ('Zusammenbruch') that is more common in written form" (Fülberth 2018, 107, translation from German).

In the English language, according to the Oxford Dictionary one of the meanings of the verb "to fold" is that something economic is ceasing "trading or operating as a result of financial problems"2. Engels's editorial change is feasible and does not change the meaning of the sentence. Neither Engels's edition of the passage nor Marx's original wording imply that capitalism automatically collapses because the key point is that Marx says that there are counteracting tendencies so that there is a dialectic of the tendency of breakdown and the tendency of stabilisation in the capitalist economy. This dialectic results in crises, from which capitalism can recover if the capitalist class manages to succeed in class struggles against the proletariat by various measures (that Marx calls "countervailing tendencies”, „entgegenwirkende Ursachen”) such as lowering wages, increasing the rate of exploitation, cheapening constant capital, etc.

Authors such as Heinrich, Vollgraf, and Jungnickel, who follow particular interpretations of Marx and Engels, blame Engels for having introduced a breakdown theory to Marx, while in reality Engels did not change the meaning of Marx's writing, but he simply used a German term that is more common and better understandable, but expresses the same meaning. „klappen” and „zusammenbrechen” have quite similar German meanings in respect to an economic system. Engels was a thorough, organised, and systematic intellectual worker, who made an important original contribution to socialist theory. Without his support of Marx and his editorial work, there would be no Capital at all.

Functionalist Marxists such as Henryk Grossmann, who assumed that capitalism would automatically break down, interpreted the passage in question from Capital Volume 3 as breakdown law of capitalism (Grossmann 1979, 79). Even if Engels had left the term „klappen” instead of "Zusammenbruch”, Grossmann and others would have made the same interpretation. The absolute breakdown is an (incorrect) interpretation of Marx and Engels that can neither be found in Marx's original manuscripts nor in Engels' edition.

Marx and Engels stress the importance of the structural conditions of class struggles in society, capitalism, and history. Capitalism's antagonisms again and again result in crises, but the results of these crises are relatively open because class struggle is an element of conditioned and relative chance whose results are not determined in

\footnotetext{
${ }^{1}$ https://www.linguee.com/english-german/search?source=auto\&query=klappen+, accessed on 4 August 2020.

${ }^{2}$ https://www.lexico.com/definition/fold, accessed on 4 August 2020.
} 
advance. In editing Capital Volumes 2 and 3, Engels "did a solid job of interpreting Marx's drafts and there was no real distortion" (Roberts 2020, 110).

\section{The tripleC-Special Issue "Engels@200: Friedrich Engels in the Age of Digital Capitalism"}

November 28, 2020, marks the $200^{\text {th }}$ birthday of Friedrich Engels. tripleC: Communication, Capitalism \& Critique celebrates Engels' birthday with a special issue, in which critical theorists reflect on the relevance of Engels' works for the analysis of digital and communicative capitalism. The special issue's contributions provide perspectives that address the question: How do Friedrich Engels' works matter for the critical analysis of digital and communicative capitalism?

The contributions deal with questions such as:

- How do the digital conditions of the working class look like today?

- What are digital working class struggles and how do they operate?

- What is the role of reproductive labour, including digital housework and digital housewifisation, in digital capitalism?

- What are Engels' contributions to a Marxist-humanist critique of digital capitalism?

- What is digital scientific socialism? What are the roles of theory, empirical research, and the critique of positivism in digital scientific socialism?

- What is digital dialectics? How does digital dialectics matter for critical digital social research? How does digital dialectics differ from the dialectics of nature?

- How do Engels' critiques of Schelling and/or Feuerbach and/or Bruno Bauer matter for the analysis of digital capitalism?

- What principles of digital commons are there and how do they matter today?

- How can we make sense of digital utopias today?

Christian Fuchs's article holds the title “Engels@200: Friedrich Engels and Digital Capitalism. How Relevant Are Engels's Works 200 Years After His Birth?". He discusses the relevance of Engels' works for the critique of the political economy of digital capitalism. The paper discusses how to think of scientific socialism as critical social science today, presents a critique of computational social science as digital positivism, engages with foundations of digital labour analysis, the analysis of the international division of digital labour, updates Engels's Condition of the Working Class in England in the age of digital capitalism in order to analyse the digital conditions of the working class today, analyses the role of trade unions and digital class struggles in digital age, analyses the social murder of workers in the COVID-19 crisis, engages with platform co-operatives, digital commons projects and public service Internet platforms are concrete digital utopias that point beyond digital capital(ism).

In the paper "Engels's Theory of Social Murder and the Spectacle of Fascism: A Critical Enquiry into Digital Labour and its Alienation", Aishik Saha argues that criticism of Christian Fuchs's critical theory of digital labour are short-sighted. The author utilises Engels's concept of social murder in order to make this point and to analyse how digital capitalism has supported the emergence of new forms and platforms of fascism. Saha stresses the fascist potentials of capitalism and argues that in the age of digital capitalism, social murder takes on the form of the interaction of violence and the spectacle that underpin the emergence of fascism.

In the article "Digital Capitalism and Coal Mine Workers", Akın Bakioğlu re-visits Engels's The Condition of the Working Class in England for the analysis of the working conditions of miners in digital capitalism. The author stresses that physical resources such as coal remain of crucial importance in digital capitalism. The analysis shows the 
specific characteristics of mine labour such as labour-intensity, a low degree of mechanisation, and highly dangerous, high-risk labour. The author shows how the profits of digital corporation is built on the blood, sweat and tears of mine workers and stresses the importance of strikes as means of resistance.

In the article "Revisiting Friedrich Engels's Dialectics of Nature in an Age of Digital Idealism", Christopher Leslie rereads and renews Engels's Dialectics of Nature in the context of contemporary science and technology, especially STEM research. He argues that the dominant approach in STEM research is idealist in character. The article reminds us that Engels's dialectical thought enables us to understand science and technology in the context of and in interrelationship with society and capitalism. Engels has influenced the development of a critical, dialectical theory of science, technology and society.

In the article "Break or Continuity? Friedrich Engels and the Critique of Digital Surveillance", Dimitrios Kivotidis analyses how Engels's works can inspire the critique of surveillance. The author takes Engels as inspiration for criticizing Shoshanna Zuboff's analysis that "surveillance capitalism" means a radical break in the development of capitalism. The article also points out foundations of a Marxian and Engelsian critique of surveillance. Such analyses stress the importance of the interconnection of surveillance and the relations of production.

In their article "The Digital Economy of the Sourdough: Housewifisation and Exploitation as Self-Exploitation", Julianna Faludi and Michelle Crosby re-actualise Engels with the help of a feminist analysis of housewifisation and digital capitalism in the COVID-19 crisis. The authors frame the analysis by a reading of Engels's The Origin of the Family, Private Property and the State. The authors point out that digital capitalism has amplified the commodification of sexuality. The article analyses changes of online dating, violence against women, the division of labour, childcare, housework, the convergence of the home and the workplace, digital communication, as well as alienation in the context of the COVID-19 crisis.

Klaus Fuchs-Kittowski's article is titled "On the Categories of Possibility, Limiting Conditions and the Qualitative Development Stages of Matter in the Thought of Friedrich Engels". It revisits and updates Engels's dialectical philosophy. The author presents a stage model of the evolution of matter and updates dialectical philosophy in the context of information theory, self-organisation theory, and quantum physics. Dialectical philosophy is opposed to mechanical, reductionist thinking and logic. In the age of digital technologies and surveillance/digital capitalism, mechanistic materialism and the reduction of humans to the level of machines and things poses dangers such as a new world war and a new fascism. Fuchs-Kittowski argues that dialectical humanism advances a logic opposed to these developments by focusing on the dialectics of chance and necessity and stressing that human practices are based on conscious decision-making, conscious self-control, creativity, and freedom.

Saayan Chattopadhyay and Suhmita Pandit's article holds the title "Freedom, Distribution and Work from Home: Rereading Engels in the Time of the COVID-19Pandemic". The paper analyses work from home in the COVD-19 crisis based on Friedrich Engels's works. It gives special attention to software companies' work from home policies and the situation in developing countries such as India. Based on Engels's analysis of the housing question and the social question in capitalism, the authors show what problems digital workers have faced when working from home and what special problems workers have faced in developing countries. 
Shahram Azhar's paper holds the title "The Conditions of the Global Digital Working Class: The Continuing Relevance of Friedrich Engels to Theorising Platform Labour". It shows the relevance of Engels's The Condition of the Working Class in England for the analysis of crowdlabour in digital capitalism. The author focuses especially on showing how Engels' analyses of class relations, inter-worker competition, labour contracts, management, surplus-population, racism, patriarchy matter for understanding the critical political economy of crowdlabour today.

Suddhabrata Deb Roy's article focuses on "The Political Economy of WorkingClass Social Media Commerce: Digital Capitalism and the Engelsian Concept of Working-Class 'Property'”. The author re-visits Engels's concept of property and re-actualises the Engelsian analysis of property in the context of social media. The paper presents an empirical case study, namely how Facebook is used as platform for primarily organising commodity resales (second hand sales) in Dunedin, the second-largest city located on New Zealand's South Island. The paper shows how capitalism is forcing the working class to resell its property via platforms such as Facebook.

\section{References}

Altvater, Elmar. 2016. The Capitalocene, or, Geoengineering against Capitalism's Planetary Boundaries. In Anthropocene or Capitalocene? Nature, History, and the Crisis of Capitalism, edited by Jason W. Moore, 138-152. Oakland: PM Press.

Altvater, Elmar. 2015. Engels neu entdecken. Da hellblaue Bändchen zur Einführung in die „Dialektik der Natur" und die Kritik von Akkumulation und Wachstum. Hamburg: VSA.

Backhaus, Hans-Georg. 1997. Dialektik der Wertform: Untersuchungen zur Marxschen Ökonomiekritik. Freiburg: Ca ira.

Barrett, Michèle. 1980. Women's Oppression Today. Problems in Marxist Feminist Analysis. London: Verso.

Eisenstein, Zillah. 1979. Developing a Theory of Capitalist Patriarchy and Socialist Feminism. In Capitalist Patriarchy and the Case for Socialist Feminism, edited by Zillah Eisenstein, 5-40. New York: Monthly Review Press.

Engels, Friedrich. 1925. Dialectics of Nature. In Marx \& Engels Collected Works (MECW) Volume 25, 311-588. London: Lawrence \& Wishart.

Engels, Friedrich. 1894. On the History of Early Christianity. In Marx \& Engels Collected Works (MECW) Volume 27, 445-469. London: Lawrence \& Wishart.

Engels, Friedrich. 1893. Can Europe Disarm? In Marx \& Engels Collected Works (MECW) Volume 26, 367-393. London: Lawrence \& Wishart.

Engels, Friedrich. 1891. The Origin of the Family, Private Property and the State. In the Light of the Researches by Lewis H. Morgan. In Marx \& Engels Collected Works (MECW) Volume 26, 129-276. London: Lawrence \& Wishart.

Engels, Friedrich. 1888. Ludwig Feuerbach and the End of Classical German Philosophy. In Marx \& Engels Collected Works (MECW) Volume 26, 353-398. London: Lawrence \& Wishart.

Engels, Friedrich. 1880. Socialism: Utopian and Scientific. In Marx \& Engels Collected Works (MECW) Volume 24, 281-325. London: Lawrence \& Wishart.

Engels, Friedrich. 1878. Anti-Dühring. Herr Eugen Dühring's Revolution in Science. In Marx \& Engels Collected Works (MECW) Volume 25, 5-309. London: Lawrence \& Wishart.

Engels, Friedrich. 1872. The Housing Question. In Marx \& Engels Collected Works (MECW) Volume 23, 317-391. London: Lawrence \& Wishart.

Engels, Friedrich. 1870/1871. Notes on the War. In Marx \& Engels Collected Works (MECW) Volume 22, 9-258. London: Lawrence \& Wishart.

Engels, Friedrich. 1859. Po and Rhine. In Marx \& Engels Collected Works (MECW) Volume 16, 211-255. London: Lawrence \& Wishart. 
Engels, Friedrich. 1850. The Peasant War in Germany. In Marx \& Engels Collected Works (MECW) Volume 10, 397-482. London: Lawrence \& Wishart.

Engels, Friedrich. 1847a. Draft of a Communist Confession of Faith. In Marx \& Engels Collected Works (MECW) Volume 6, 96-103. London: Lawrence \& Wishart.

Engels, Friedrich. 1847b. Principles of Communism. In Marx \& Engels Collected Works (MECW) Volume 6, 341-357. London: Lawrence \& Wishart.

Engels, Friedrich. 1845a. Speeches in Elberfeld. In Marx \& Engels Collected Works (MECW) Volume 4, 243-264. London: Lawrence \& Wishart.

Engels, Friedrich. 1845b. The Condition of the Working Class in England. Oxford: Oxford University Press.

Engels, Friedrich. 1843. Outlines of a Critique of Political Economy. In Marx \& Engels Collected Works (MECW) Volume 3, 418-443. London: Lawrence \& Wishart.

Engels, Friedrich.1842a. Schelling and Revelation: Critique of the Latest Attempt of Reaction against the Free Philosophy. In Marx \& Engels Collected Works (MECW) Volume 2, 189244. London: Lawrence \& Wishart.

Engels, Friedrich.1842b. Schelling, Philosopher in Christ. In Marx \& Engels Collected Works (MECW) Volume 2, 245-264. London: Lawrence \& Wishart.

Engels, Friedrich.1841. Schelling on Hegel. In Marx \& Engels Collected Works (MECW) Volume 2, 181-187. London: Lawrence \& Wishart.

Engels, Friedrich. 1839. Letters from Wuppertal. In Marx \& Engels Collected Works (MECW) Volume 2, 7-25. London: Lawrence \& Wishart.

Federici, Silvia. 2012. Revolution at Point Zero: Housework, Reproduction, and Feminist Struggle. Oakland: PM Press.

Fraser, Nancy and Rahel Jaeggi. 2018. Capitalism: A Conversation in Critical Theory. Cambridge: Polity.

Fuchs, Christian. 2020. Communication and Capitalism: A Critical Theory. London: University of Westminster Press. DOI: https://doi.org/10.16997/book45

Fuchs, Christian. 2006. The Dialectic of the Nature-Society-System. tripleC 4 (1): 1-39. DOI: https://doi.org/10.31269/triplec.v4i1.24

Fuchs, Christian. 2003. The Self-Organization of Matter. Nature, Society, and Thought 16 (3): 281-313.

Fülberth, Georg. 2020. Wie zwei ein Compagniegeschäft betrieben. Friedrich Engels' Beitrag zum Werk von Karl Marx. In „Die Natur ist die Probe auf die Dialektik“: Friedrich Engels kennenlernen, 54-68. Hamburg: VSA.

Fülberth, Georg. 2018. Friedrich Engels. Köln: PapyRossa.

Gimenez, Martha. 1987. Marxist and Non-Marxist Elements in Engels's Views on the Oppression of Women. In Engels Revisited: New Feminist Essays, edited by Janet Sayers, Mary Evans and Nanneke Redclift, 37-56. London: Tavistock.

Grossmann, Henryk. 1929. Das Akkumulations- und Zusammenbruchsgesetz des kapitalistischen Systems. Leipzig: Verlag von C.L. Hirschfeld.

Haug, Frigga. 2015. Gender Relations \& The Marx Within Feminism. In Marxism and Feminism, edited by Shahrzad Mojab, 33-101. London: Zed.

Haug, Wolfgang Fritz. 2003. Historisches/Logisches. Das Argument 251: 378-396.

Hecker, Rolf. 2018. Springpunkte. Beiträge zur Marx-Forschung und „Kapital“-Diskussion. Berlin: Dietz.

Heinrich, Michael. 2006. Die Wissenschaft vom Wert. Münster: Westfälisches Dampfboot. Fourth edition.

Hobsbawm, Eric J. 2011. How to Change the World: Reflections on Marx and Marxism. New Haven: Yale University Press.

Kopf, Eike. 2017. Marxismus ohne Engels? Köln: PapyRossa.

Krätke, Michael. 2020. Friedrich Engels oder: Wie ein "Cotton-Lord" den Marxismus erfand. Berlin: Dietz. 
Kurz, Heinz D. 2000. Der junge Engels über die „Bereicherungswissenschaft“, die "Unsittlichket“ von Privateigentum und Konkurrenz und die „Heuchelei der Oekonomen“. In Arbeiten am Widerspruch - Friedrich Engels zum 200. Geburtstag, edited by Rainer Lucas, Reinhard Pfrim and Hans-Dieter Westhoff, 65-120. Marburg: Metropolis.

Leacock, Eleanor Burke. 2008. Myths of Male Dominance: Collected Articles on Women Cross-Culturally. Chicago: Haymarket Books.

Lenin, Vladimir I. 1913. The Three Sources and Three Component Parts of Marxism. In Lenin Collected Works Volume 19, 21-28. Moscow: Progress.

Liedman, Sven-Eric. 2018. A World to Win: The Life and Works of Karl Marx. London: Verso.

Marx, Karl. 1894a. Das Kapital. Dritter Band. Marx Engels Werke (MEW) Band 25. Berlin: Dietz.

Marx, Karl. 1894b. Capital. Volume III. Marx \& Engels Collected Works (MECW) Volume 37. London: Lawrence \& Wishart.

Marx, Karl. 1894c. Capital. Volume III. London: Penguin.

Marx, Karl. 1867. Capital. Volume I. London: Penguin.

Marx, Karl. 1863-1865a. Ökonomische Manuskripte 1863-1867. Teil 2. Manuskript 1863/65 zum 3. Buch des „Kapital“. Marx/Engels Gesamtausgabe (MEGA) II.4/2. Berlin: De Gruyter.

Marx, Karl. 1863-1865b. Marx's Economic Manuscript of 1864-1865. Leiden: Brill.

Marx, Karl. 1863. Marx to Engels, 9 April 1863. In Marx \& Engels Collected Works (MECW) Volume 41, 466-469. London: Lawrence \& Wishart.

Marx, Karl. 1859. A Contribution to the Critique of Political Economy. Preface. In Marx \& Engels Collected Works (MECW) Volume 29, 261-265. London: Lawrence \& Wishart.

Marx, Karl and Friedrich Engels. 1848. The Manifesto of the Communist Party. In Marx \& Engels Collected Works (MECW) Volume 6, 477-519. London: Lawrence \& Wishart.

Marx, Karl and Friedrich Engels. 1845/1846. The German Ideology. Critique of Modern German Philosophy According to Its Representatives Feuerbach, B. Bauer and Stirner, and of German Socialism According to Its Various Prophets. In Marx \& Engels Collected Works (MECW) Volume 5, 19-539. London: Lawrence \& Wishart.

Marx, Karl and Friedrich Engels. 1845. The Holy Family, or Critique of Critical Criticism. Against Bruno Bauer and Company. In Marx \& Engels Collected Works (MECW) Volume 4, 5-211. London: Lawrence \& Wishart.

Notz, Gisela. 2000. Auseinandersetzung mit Friedrich Engels' „Ursprung der Familie ...“ ... und was er uns heute noch zu sagen hat. In Arbeiten am Widerspruch - Friedrich Engels zum 200. Geburtstag, ed. Rainer Lucas, Reinhard Pfrim and Hans-Dieter Westhoff, 397416. Marburg: Metropolis.

Roberts, Michael. 2020. Engels 200 - His Contribution to Political Economy. London: Lulu.com.

Rowbotham, Sheila. 1973. Woman's Consciousness, Man's World. Harmondsworth: Penguin.

Sayers, Janet, Mary Evans, and Nanneke Redclift, eds. 1987. Engels Revisited: New Feminist Essays. London: Tavistock.

Stalin, Joseph V. 1945. Dialectical and Historical Materialism. In History of the Communist Party of the Soviet Union, 105-131. Moscow: Foreign Languages Publishing House.

Vogel, Lise. 1996. Engels's Origin: Legacy, Burden and Vision. In Engels Today: A Centenary Appreciation, edited by Christopher J. Arthur, 129-151. Basingstoke: Macmillan.

Vollgraf, Carl-Erich and Jürgen Jungnickel 2002. Marx in Marx's Words: On Engels's Edition of the Main Manuscript of Book 3 of Capital. International Journal of Political Economy 32 (1): 35-78.

Zimmermann, Clemens. 2020. Die Lage der arbeitenden Klasse in England. In Friedrich Engels: Ein Gespenst geht um in Euopa. Begleitband zur Engelsausstellung 2020, edited by Lars Bluma, 70-83. Remscheid: Bergischer Verlag. 


\section{About the Author}

Christian Fuchs

Christian Fuchs is a critical theorist and the co-editor of tripleC: Communication, Capitalism \& Critique (http://www.triple-c.at). http://fuchsc.net, @fuchschristian 


\title{
Engels@200: Friedrich Engels and Digital Capitalism. How Relevant Are Engels's Works 200 Years After His Birth?
}

\author{
Christian Fuchs
}

\author{
University of Westminster, christian.fuchs@uti.at, http://fuchs.uti.at, \\ @fuchschristian
}

\begin{abstract}
This paper takes Friedrich Engels $200^{\text {th }}$ birthday on 28 November 2020 as occasion to ask: How relevant are Friedrich Engels's works in the age of digital capitalism? It shows that Engels class-struggle oriented theory can and should inform $21^{\text {st }}$ century social science and digital social research. Based on a reading of Engels's works, the article discusses how to think of scientific socialism as critical social science today, presents a critique of computational social science as digital positivism, engages with foundations of digital labour analysis, the analysis of the international division of digital labour, updates Engels's Condition of the Working Class in England in the age of digital capitalism, analyses the role of trade unions and digital class struggles in digital age, analyses the social murder of workers in the COVID-19 crisis, engages with platform co-operatives, digital commons projects and public service Internet platforms are concrete digital utopias that point beyond digital capital(ism). Engels's analysis is updated for critically analysing the digital conditions of the working class today, including the digital labour of hardware assemblers at Foxconn and Pegatron, the digital labour aristocracy of software engineers at Google, online freelance workers, platform workers at capitalist platform corporations such as Uber, Deliveroo, Fiverr, Upwork, or Freelancer, and the digital labour of Facebook users. Engels's $200^{\text {th }}$ birthday reminds us of the class character of digital capitalism and that we need critical digital social science as a new form of scientific socialism.
\end{abstract}

Keywords: Friedrich Engels, 200 ${ }^{\text {th }}$ birthday, anniversary, digital capitalism, digital capital, digital labour, digital commons, The Condition of the Working Class in England, critical digital research, critical digital social science, scientific socialism, international division of digital labour, digital commodity, computational social science, digital positivism, social murder, COVID-19 crisis, coronavirus, pandemic, Foxconn, Pegatron, Google, software engineering, digital labour aristocracy, online freelancers, Uber, Deliveroo, Fiverr, Upwork, Freelancer, Facebook, class struggles, working class, public service Internet platforms, platform co-operatives, Outlines of a Critique of Political Economy; The Origin of the Family, Private Property and the State; Anti-Dühring, Socialism: Utopian and Scientific, Ludwig Feuerbach and the End of Classical German Philosophy, Dialectics of Nature, Karl Marx 


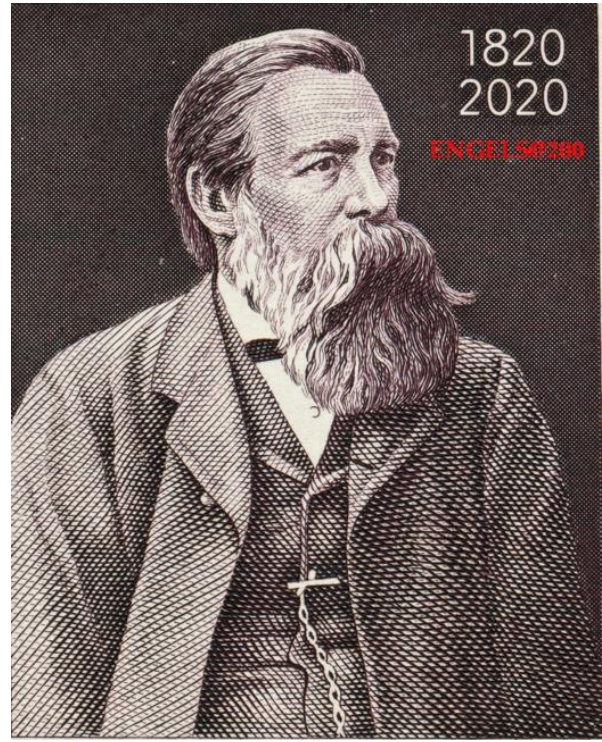

\section{Introduction}

28 November 2020: Friedrich Engels was born 200 years ago on 28 November 1820. Together with Karl Marx, Engels was the founder of the critique of the political economy. He was a theorist, historian, journalist, philosopher, politician and entrepreneur who used the money capital he accumulated for support Marx and the international socialist movement. In 2020, capitalism has changed, but is still around. Engels's $200^{\text {th }}$ anniversary is a good occasion in order to ask: How relevant are Friedrich Engels's works in the age of digital capitalism? This essay deals with this question.

Engels together with Marx wrote the Manifesto of the Communist Party, The German Ideology, and The Holy Family. Engels also helped out Marx with writing newspaper articles that appeared under Marx's name. And he made a genuine contribution to critical theory with works such as Anti-Schelling (Schelling and Revelation), Outlines of a Critique of Political Economy, The Condition of the Working Class in England, The Housing Question, Anti-Dühring, Socialism: Utopian and Scientific, Dialectics of Nature; The Origin of the Family, Private Property and the State; Ludwig Feuerbach and the End of Classical German Philosophy. This article discusses the relevance of a variety of Engels's works for the critical analysis of digital capitalism with a special focus on The Condition of the Working Class in England because we are interested in the condition of the working class in digital capitalism today.

Section 2 discusses the role of history and class struggles in Engels's works. It deals with the question whether or not Engels was a vulgariser of Marx's theory, who advanced a deterministic concept of history. Section 3 outlines a critique of computational social science based on Engels's understanding of scientific socialism. Section 4 analyses the digital condition of the working class today. It uses Engels's works, especially his book The Condition of the Working Class in England, for analysing the digital labour of hardware assemblers, Google software engineers, platform workers, and Facebook users. The section also analyses the role of productivity gains achieved by digital automation and robotisation and labour inequalities in the COVID-19 crisis. Section 6 discusses working class struggles in digital capitalism. Section 6 draws conclusions.

\section{Engels, History, Class Struggles}

Positions on the intellectual relationship of Marx and Engels are split. There are on the 
one hand those who argue that Engels misunderstood, manipulated and vulgarised Marx's theory and thereby not just turned Marx into Marxism but also laid the grounds for Stalinism (see e.g. Carver 1981; 1983; 1990; Levine 1975; 2006; Schmidt 1971). And there are those who say that Engels made his own contributions to socialist theory, but that there is no major theoretical difference between Marx and Engels (see e.g. Blackledge 2019; Fülberth 2018; Kopf 2017; Krätke 2020; Mayer 1935). The representatives of this position hold that Engels was a not just Marx's best friend, but also his closest intellectual companion so that there would be not Marx without Engels.

Terrell Carver and Norman Levine are two of the theorists who hold the first position Carver $(1981,93)$ writes that Marx and Engels had "different approaches to social science and perhaps politics itself". "Engels's influence has chiefly been on the theoretical side of Marxism, and his 'dialectics' and 'materialism' are notably memorialized in official Soviet philosophy" (Carver 1990, 257). Levine (2018, 195-196) argues that Engels neglected: "Engelsian Leninism was founded upon the belief that the meteoric advancement of science made socialism attainable and therefore led to the prioritization of the forces of production. [...] Engelsian Leninism rested upon de-politicization" (Levine 2018, 195-196). Levine's arguments imply that there is a lack of focus on class struggle in Engels's works.

Stalinism eulogised elements from some of Engels's works. In his essay "Dialectical and Historical Materialism" published in the History of the Communist Party of the Soviet Union Bolsheviks: Short Course - the ideological bible of Stalinism -, Stalin (1945) references and quotes from Engels's Anti-Dühring, Dialectics of Nature, and Feuerbach and the End of Classical German Philosophy.

Stalin (1945) directly applies some aspects of the dialectics of nature to society and claims that this means that revolutions and the transition to socialism are inevitable:

If the connection between the phenomena of nature and their interdependence are laws of the development of nature, it follows, too, that the connection and interdependence of the phenomena of social life are laws of the development of society, and not something accidental. Hence, social life, the history of society, ceases to be an agglomeration of 'accidents', for the history of society becomes a development of society according to regular laws, and the study of the history of society becomes a science (114).

Further, if the passing of slow quantitative changes into rapid and abrupt qualitative changes is a law of development, then it is clear that revolutions made by oppressed classes are a quite natural and inevitable phenomenon (111).

For Stalin, socialism as science does not mean a science of society that is different from the natural sciences, but deterministic and mechanical social laws of nature operating in society. The implication is for Stalin that history develops in a linear manner, it is for him a "process of development from the lower to the higher" (Stalin 1939, 109). Stalin argues that the Soviet Union followed capitalism and therefore was a socialist system: "[T]he U.S.S.R. has already done away with capitalism and has set up a Socialist system" (Stalin 1945, 119). His implication was that anyone critical of him was bourgeois and anti-socialist. The mechanical interpretation of the dialectic legitimated Stalin's terror against his opponents.

The concepts of Aufhebung (sublation) and the negation of the negation are missing in Stalinist dialectics. They are however key features of Engels's dialectics. Stalin referred to Engels, but Engels's interpretation of dialectics was other than Stalin's not 
based on mechanical and deterministic concepts. Engels is not be blamed for Stalinism.

In Engels's canonical works, there are some problematic formulations. For example, he writes that "the capitalist mode of production has likewise itself created the material conditions from which it must perish" (Engels 1878, 122) or that there is the "inevitable downfall" of the capitalistic mode of production (Engels 1880, 305). Such formulations create the impression that society is governed by mechanistic and deterministic laws.

But Engels (1878) stresses in the same works where the mentioned problematic formulations can be found that there is a difference between the negation of the negation in nature and in society. The dialectic has in each realm of the world "specific peculiarities" (Engels 1878, 131). The "history of the development of society turns out to be essentially different from that of nature" because humans "are all endowed with consciousness, are men acting with deliberation or passion, working towards definite goals" (Engels 1888, 387). Humans would act with intentions towards specific goals, but the outcomes would often be quite different from the intentions, which is an element of chance in society that is, however, "governed by inner, hidden laws" (Engels 1888, $387)$. He describes the proletarian revolution as the solution of capitalism's contradictions (Engels 1880, 325). "To accomplish this act of universal emancipation is the historical mission of the modern proletariat". A mission does not necessarily succeed. In these passages, Engels stresses that society operates on dialectical laws that are different from the laws of nature. The question is, however, what a law is in society. The more problematic formulations that can be found in these works can imply that capitalism automatically breaks down. But more frequently Engels stresses in the same works that history is the history of class struggles, for example: "In modern history at least it is, therefore, proved that all political struggles are class struggles, and all class struggles for emancipation, despite their necessarily political form - for every class struggle is a political struggle - turn ultimately on the question of economic emancipation" (Engels $1888,387-388,391)$. It is one of the laws of society that change happens through human practices and that in class society, class struggle is the decisive practice of transformation.

This assumption is also in line with Marx's and Engels's view of history in their early works. In The Holy Family, the first work that Marx and Engels co-authored, Engels writes: "History does nothing, it 'possesses no immense wealth', it 'wages no battles'. It is man, real, living man who does all that, who possesses and fights; 'history' is not, as it were, a person apart, using man as a means to achieve its own aims; history is nothing but the activity of man pursuing his aims" (Marx and Engels 1845, 93). In The Manifesto of the Communist Party, Marx and Engels (1848b, 482) say: "The history of all hitherto existing society is the history of class struggles". Marx added to the law of class struggle the law of the dialectic of structures and agency, of societal conditions and practices. Humans "make their own history, but they do not make it just as they please; they do not make it under circumstances chosen by themselves, but under circumstances directly encountered, given and transmitted from the past" (Marx 1852, 103). Society's transformation is based on dialectics of chance/necessity, freedom/determination, discontinuity/continuity, practices/structural conditions. In capitalism, the class contradiction and the contradiction between productive forces and relations of production with necessity call forth crises. The outcome of such crises is not determined and depends on the results of class struggles. Society's dialectic is a dialectic of objective contradictions and the human subjects' practices. 
If Marx and Engels had assumed that capitalism would automatically break down and socialism would emerge inevitably, why would they have engaged in practical revolutionary activity? Engels participated, for example, active in the 1849 revolutionary uprising for democracy in Elberfeld and Baden. Marx and Engels were leaders of the League of the Just, the Communist League, and the First International. Engels's single deterministic historical formulations seem to have served the rhetorical-political purpose of motivating revolutionary optimism among activists.

In a letter to Borgius, Engels (1894) stresses that humans "make their history themselves, only in given surroundings which condition it and on the basis of actual relations already existing, among which the economic relations" form "the red thread which runs through them". The notion of the economic as read thread allows us to see the economic, i.e. social production, as the universal and common element of all social realms. Social production takes on different forms with emergent meanings but also is the red thread of society and its various spheres (see Fuchs 2020a).

Blackledge $(2019,240)$ stresses that by scientific socialism Engels did not understand "empiricism or positivism" and "a mechanical and fatalistic model of agency. "Engels was neither an empiricist nor a positivist. And as regards the charge of reductionism, he held to a stratified view of natural and social reality according to which emergent properties at each level could neither be reduced to laws governing the levels below them, nor could the laws through which they operated be understood in an empiricist or positivist fashion".

Engels stresses in Socialism: Utopian and Scientific in line with Marx's Grundrisse and Capital that science and technology are on the one hand "the most powerful weapon in the war of capital against the working-class" (Engels 1880, 314) and on the other hand important means of emancipation from capitalism and class society that support the establishment and reproduction of "the kingdom of freedom" beyond necessity (Engels 1880, 324).

Taken together, there is no doubt that there are some problematic formulations in Engels's canonical works. But a more pertinent reading is that he and Marx interpreted history as a dialectic of class struggles and structural conditions, which implies that there is no automatic breakdown of capitalism. The implication is also, as Tristam Hunt $(2009,361)$ stresses in his Engels-biography that Engels and Marx are not to blame for Stalin's terror:

In no intelligible sense can Engels or Marx bear culpability for the crimes of historical actors carried out generations later, even if the policies were offered up in their honor. Just as Adam Smith is not to blame for the inequalities of the free market West, nor Martin Luther for the nature of modern Protestant evangelicalism, nor the Prophet Muhammad for the atrocities of Osama bin Laden, so the millions of souls dispatched by Stalinism (or by Mao's China, Pol Pot's Cambodia, and Mengistu's Ethiopia) did not go to their graves on account of two nineteenth-century London philosophers.

Although there are single problematic passages in Engels's works that imply that capitalism must automatically collapse, there are other passages that stress the difference of dialectical laws in nature and society and that a key social law found in class societies is that humans make their own history under given conditions and in class societies do so in the form of class and social struggles. Scientific socialism doesn't mean that society is governed by mechanical laws, but that socialist research studies society based on the combination of critical social theory and critical empirical social research. 


\section{Computational Social Science and Scientific Socialism}

To speak of "scientific socialism" doesn't automatically and not necessarily apply a mechanistic and deterministic theory of society that assumes that capitalism automatically breaks down and society is determined by natural economic laws. The scientific understanding of socialism is not a natural science applied society but rather a social science of society (Gesellschaftswissenschaft) that stresses the key role of the conscious human being, social practices, social production, and social relations in society. Natural science theories are not necessarily deterministic and mechanistic. The point is that in the social sciences, the positivist tradition treated society based on natural science methods and mathematics, which focuses on pure quantification and assumes that everything can be calculated. The logic of positivism neglects society's qualities and the fact that not everything social and societal is calculable. We cannot properly calculate love, morals, sadness, happiness, (dis)respect, (in)justice, solidarity, etc. Society's social qualities can only be properly analysed by qualitative social research methods. Marx and Engels are not as such opposed to calculation and quantification, but they are critical of computing as means of domination and exploitation that drives capital accumulation and makes the qualities of society disappear behind things and numbers. This critique of quantification as aspect of capitalist accumulation has been reflected in Georg Lukács' (1971) notion of reification and Max Horkheimer's (1947) notion of instrumental reason.

In the contemporary social sciences, computational social sciences have emerged as a dominant paradigm that attracts lots of attention, support, funding and has increasingly been institutionalised.

David Lazer et al. $(2009,722)$ define computational social science as social science that "leverages the capacity to collect and analyze data with an unprecedented breadth and depth and scale" and operates with "terabytes of data". In the textbook Introduction to Computational Social Science, Cioffi-Revilla $(2014,2)$ defines computational social science: "The new field of Computational Social Science can be defined as the interdisciplinary investigation of the social universe on many scales, ranging from individual actors to the largest groupings, through the medium of computation. [...] Computational social science is based on an information-processing paradigm of society" (Cioffi-Revilla 2014, 2).

The Manifesto of Computational Social Science (Conte et al. 2012) argues that computational social science operates with "massive ICT data" (327), conducts "massive data analysis" (330) that operates "up to the whole world population" (331). It is "a new field of science in which new type of data, largely made available by new ICT applications, can be used to produce large-scale computational models of social phenomena" (333). The Manifesto claims that computational social science constitutes "a new era" (327).

Computational social scientists set out to radically transform the social sciences. Computational social science is a new positivism. Its methods cannot understand the qualitative features of society such as motivations, norms, moral values, feelings, ideologies, experiences.

Cioffi-Revilla $(2014,1)$ explicitly situations computational social science in the context of Auguste Comte's "natural science of social systems, complete with statistical and mathematical foundations". Comte was the founder of positivism. Computational social science explicitly stands in the context of positivism. The Manifesto of Computational Social Science argues for turning sociology and the social sciences into a natural science: "sociology in particular and the social sciences in general would undergo 
a dramatic paradigm shift, arising from the incorporation of the scientific method of physical sciences" (Conte et al. 2012, 341).

The danger is that computer science colonises the social sciences and leaves no space and time for critical theory, social theory, philosophy. The main danger of the computational social sciences is that it makes the social sciences uncritical and turns them into administrative sciences (see Fuchs 2017a). Engels warned in a different context of the dangers of positivism. He argues against a mathematical method that is "reducing qualitative differences to merely quantitative differences [...] As Hegel has already shown (Encyclopädie, I, S. 199), this view, this 'one-sided mathematical view', according to which matter must be looked upon as having only quantitative determination, but, qualitatively, as identical originally, is 'no other standpoint than that' of the French materialism of the eighteenth century. It is even a retreat to Pythagoras who regarded quantitative determination as the essence of things" (Engels 1925, 534). For Engels $(1925,469)$, such reductive approaches are a form of "naïve materialism".

Engels criticises mechanical materialism that does not see and analyse the qualitative and dialectical aspects of the world. Engels in this passage refers to the first part of Hegel's Encyclopaedia, where Hegel discusses the dialectical logic. The reference is to the discussion of pure quantity as aspect of quantity. Hegel writes in this passage that "when we look closely at the exclusively mathematical standpoint that is here referred to (according to which quantity, which is a definite stage of the logical Idea, is identified with the Idea itself) we see that it is none other than the standpoint of Materialism" (Hegel 1830/1991, 159, addition to §99). He stresses that "freedom, law, ethical life [...] cannot be measured and computed or expressed in a mathematical formula" (Hegel 1830/1991, 159, addition to §99) and that "we know very little about these things and the distinction between them, if we simply stick to a 'more or less' of this kind, and do not advance to some grasp of specific determinacy, which is here in the first place qualitative" (Hegel 1830/1991, 160, addition to §99).

Hegel and Engels remind us that computational social science cannot grasp society's dialectical relations that are not easily quantifiable. It cannot understand, model, calculate freedom, law, moral judgement, love, etc. Its analyses are one-dimensional. Critical social science should certainly adopt and experiment with data-driven methods, but not at the expense of the engagement with and application of critical theory (Fuchs 2017a). Digital data gathered on social media and other data-intensive environments can reveal important aspects of life in contemporary societies. What is needed are not simply new forms of prediction and quantification, but critical, creative and experimental methods that combine aspects of quantitative data with a qualitative understanding of humans' motivations, experiences, interpretations, norms and values (Fuchs 2017a). Whereas Marx and Engels were social scientists who wrote the Communist Manifesto, some contemporary social scientists write manifestos for a new positivism and many more believe in what such manifestos postulate, which results in the institutionalisation of computational social science and big funding for big data-based methods and project. Big data analytics and computational social science miss the difference between society and nature that Engels points out. The danger is that they reduce society to quantitative data and neglect its indeterminate, open, dialectical qualities.

To speak of "scientific socialism" doesn't automatically and not necessarily apply a mechanistic and deterministic theory of society that assumes that capitalism automatically breaks down and society is determined by natural economic laws. The scientific understanding of socialism is not a natural science applied society but rather a social 
science of society (Gesellschaftswissenschaft) that stresses the key role of the conscious human being, social practices, social production, and social relations in society. Natural science theories are not necessarily deterministic and mechanistic. The point is that in the social sciences, the positivist tradition treated society based on natural science methods and mathematics, which focuses on pure quantification and assumes that everything can be calculated.

The logic of positivism neglects society's qualities and the fact that not everything social and societal is calculable. We cannot properly calculate love, morals, sadness, happiness, (dis)respect, (in)justice, solidarity, etc. Society's social qualities can only be properly analysed by qualitative social research methods. Marx and Engels are not as such opposed to calculation and quantification, but they are critical of computing as means of domination and exploitation that drives capital accumulation and makes the qualities of society disappear behind things and numbers. This critique of quantification as aspect of capitalist accumulation has been reflected in Georg Lukács' (1971) notion of reification and Max Horkheimer's (1947) notion of instrumental reason.

Computational social science is a paradigm in the social sciences that propagates mathematical models of society that use big data and predictive algorithms. Engels's scientific socialism is critical of positivism. Computational social science is a neo-positivism that neglects that qualitative features of society such as motivations, norms, moral values, feelings, ideologies, experiences, love, death, freedom, or (in)justice that cannot be reduced to mere quantities. Computational social science poses the danger of turning the social sciences into administrative, instrumental, positivist research that supports domination and exploitation and is a branch of computer science that has colonised the social sciences.

\section{The Digital Condition of the Working Class Today}

In this section, we will discuss the situation of the working class in digital capitalism. Engels's book The Condition of the Working Class in England plays an important role as starting point for such an analysis. The section introduces Engels's book (subsection 4.1), the relationship of technology and society (subsection 4.2), digital technology and relative surplus-value production (subsection 4.3), absolute surplus-value production at Foxconn (subsection 4.4), play labour at Google (subsection 4.5), precarious platform workers (subsection 4.6), labour in the COVID-19 crisis (subsection 4.7), and Facebook labour (subsection 4.8).

\subsection{The Condition of the Working Class in England}

The Condition of the Working Class in England (CWCE) is for many Engels' most influential book. Eric J. Hobsbawm writes that "the Condition is probably the earliest large work whose analysis is systematically based on the concept of the Industrial Revolution" (Hobsbawm 1969, 17). It "remains an indispensable work and a landmark in the fight for the emancipation of humanity" (Hobsbawm 1969, 17). David McLellan (1993, xix) writes that the Condition is "the first book to have dealt comprehensively with the industrial working class as a whole rather than just with particular groups or industries". Engels's method was a "[r]ich and complex" form of interdisciplinarity that combined "economics, philosophy, and labour history" (McLellan 1993, xix). Engels integrated a "rich mass of material" into "an extraordinary unity [...] articulated [...] under [...] general principles" (Mayer 1935, 62)

Engels came from a bourgeois family. His father Friedrich Engels senior (17961860 ) owned the cotton factory Ermen \& Engels that operated two cotton mills, one in Engelskirchen (Rhineland) and one in Manchester (United Kingdom). 
Engels junior conducted the research for his book The Condition of the Working Class in England (CWCE = Engels 1845) during his stay in Manchester from 1842 until 1844, where he was supposed to learn his father's trade. Engels directly experienced the working class' conditions in England and got in touch with workers, from whom he learned about their everyday life and the problems they faced. Family status does not determine one's political worldview. Born into a capitalist family, Engels became one of the international leaders of the communist movement. There is no $1: 1$ relationship and no mechanic determination of culture by the economy. Engels junior became his father's representative in the Manchester business. After the death of his father in 1860, Engels became the co-owner of the Manchester establishment. He managed the company, funded Marx's life in London, financially and intellectually supported the socialist movement, and was active as a writer. In 1869, Engels had accumulated enough wealth in order to be able to sustain himself and Marx and family, and support the socialist movement. He sold his share in Ermen \& Engels, retired from the company, and entirely devoted himself to the socialist movement and theory.

In CWCE, Engels analyses the rise, early development and consequences of capitalism in England. The decisive features he mentions are a) the working class, b) industrial technologies such as the steam-engine as moving technology and manufacturing machinery as working technology that replaced handicraft, c) the capitalist class, and d) the division of labour.

In CWCE, Engels analyses the terrible conditions that the working class had to endure in industrial England, including long working hours, low wages, poverty, overcrowded and dirty slums and dwellings, poisonous and uneatable food, overwork, starvation, death by hunger, lack of sleep, air pollution, untreated illnesses, egotism and moral indifference, crime, alcoholism, bad clothes, unemployment, rape, homelessness, lack of clean water, drainage and sanitation, illiteracy, child labour, military drill in factories, overseers' flogging and maltreatment of workers, deadly work accidents, fines, etc.

Engels characterises the misery the working class faces as "a condition unworthy of human beings" (CWCE, 43), conditions where humans cannot "think, feel, and live as human beings" (CWCE, 220), degradation to "the lowest stage of humanity" (CWCE, 73), treatment of workers "as mere material, a mere chattel" (CWCE, 66). Engels characterisation of capitalism as dehumanising resembles Marx's introduction of the notion of alienation in the Economic and Philosophic Manuscripts of 1844, where Marx $(1844,517)$ speaks of one aspect of alienation as "alienation of the human being from being human"1. Out of such words speaks the deep humanism of Engels and Marx. They both understand socialism is a humanist society that enables a good life for all humans.

Using factory inspectors' reports, parliamentary reports, observation, and the analysis of news reports, The Condition of the Working Class in England shows that Engels already in the 1840s practiced and pioneered empirical social research (Kurz 2020, 67; Krätke 2020, 29-34; Zimmermann 2020). In Capital Volume 1, Marx (1867) uses the same empirical method as Engels in CWCE, which shows that Engels's work had large influence on Marx. Marx (1867, 349 (footnote 15), 573, 755), explicitly refers positively to Engels's book several times. For example, Marx (1867, 349 [footnote 15]) writes:

\footnotetext{
1 Übersetzung aus dem Deutschen [CF]: „die Entfremdung des Menschen von dem Menschen“
} 
How well Engels understood the spirit of the capitalist mode of production is shown by the Factory Reports, Reports on Mines, etc. which have appeared since 1845, and how wonderfully he painted the circumstances in detail is seen on the most superficial comparison of his work with the official reports of the Children's Employment Commission, published eighteen to twenty years later (1863-7).

Working on Capital, Marx re-read Engels's Condition and wrote to him about the book: "With what zest and passion, what boldness of vision and absence of all learned or scientific reservations, the subject is still attacked in these pages!" (Marx 1863, 469).

\subsection{Technology and Society}

Some observers, such as McLellan (1993, xviii) argue that underlying Engels approach in CWCE is "a technological determinism that was to remain with Engels all his life". There are indeed some formulations in CWCE that can create such an impression: The "industrial revolution [...] altered the whole civil society" (CWCE, 15); the "proletariat was called into existence by the introduction of machinery" (CWCE, 29)

But Engels leaves no doubt that capitalist relations of production, i.e. private property relations, the class relation between capital and labour and the profit imperative, shape the development and application of machinery. He says that capitalism is the cause of misery: The "great central fact" is "that the cause of the miserable condition of the working class is to be sought [...] in the capitalistic system itself" (CWCE, 314). When discussing machinery, Engels points out that the social conditions under which technology exist are the factors that have decisive influence on technology's impacts on society: "The consequences of improvement in machinery under our present social conditions are, for the working man, solely injurious, and often in the highest degree oppressive" (CWCE, 149).

In CWCE, Engels often describes class relations as competition and makes clear that not machines, but transformation of class relations created the proletariat. Competition - "the battle of all against all" - "created and extended the proletariat" (CWCE, 87). Capitalist competition means a class conflict between capital and labour but also competition between capitalists that results in the centralisation of capital and competition between workers, such as between the "power-loom weaver" and "the hand-loom weaver" (CWCE, 87).

Engels (Marx and Engels 1848b, 482) inserted a note to the 1888 edition of the Manifesto, saying that by "bourgeoisie is meant the class of modern Capitalists, owners of the means of social production and employers of wage-labour. By proletariat, the class of modern wage-labourers who, having no means of production of their own, are reduced to selling their labour-power in order to live". Capital means "the direct or indirect control of the means of subsistence and production" as "the weapon with which this social warfare is carried on" (CWCE, 37-38). The bourgeoisie is the class of property-holders (CWCE, 281). The bourgeoise measures "[a]ll the conditions of life [...] by money" (CWCE, 282). The decisive aspect of technology in capitalism is that capitalists own technologies as private property that is a means of production used for accumulating capital and the production of surplus-value and commodities.

Also in Outlines of a Critique of Political Economy, a foundational text of Marx's and Engels's approach, young Engels (1843, 442-443) stresses that science and technology are instruments in the hands of the bourgeoisie: 
In the struggle of capital and land against labour, the first two elements enjoy yet another special advantage over labour - the assistance of science; for in present conditions science, too, is directed against labour. Almost all mechanical inventions, for instance, have been occasioned by the lack of labour-power; in particular Hargreaves', Crompton's and Arkwright's cotton-spinning machines. There has never been an intense demand for labour which did not result in an invention that increased labour productivity considerably, thus diverting demand away from human labour. The history of England from 1770 until now is a continuous demonstration of this. The last great invention in cotton-spinning, the self-acting mule, was occasioned solely by the demand for labour, and rising wages. It doubled machine-labour, and thereby cut down hand-labour by half; it threw half the workers out of employment, and thereby reduced the wages of the others by half; it crushed a plot of the workers against the factory owners, and destroyed the last vestige of strength with which labour had still held out in the unequal struggle against capital.

Marx $(1859,264)$ characterised the Outlines as "brilliant essay on the critique of economic categories" and directly referred to it several times in Capital Volume I (Marx 1867, 168 [footnote 30], 253 [footnote 5], 266-267 [footnote 20], 788 [footnote 15]). In the Outlines, Engels points out that "the mental element of invention, of thought" (Engels 1843,427$)$, as in the form of science, is part of human labour and the "human, subjective side, labour" (427) of production. In work, the human being is "active physically and mentally" (428). Engels here on the one hand points out the dialectic of mental and physical activity in work and on the other hand identified mental work, or what today is often called knowledge or information work, as important aspect of production.

The assumption that Engels was a technological determinist cannot be sustained. $\mathrm{He}$ analysed technology in capitalism as embedded into class relations so that there is capitalist ownership of technology as private-property that is utilised as means for the production of surplus-value, commodities, and profit.

\subsection{Digital Technology and Relative Surplus-Value Production}

In the Grundrisse, Marx (1857/58) introduced the notion of surplus-value, by which he means that workers produce unpaid labour during a portion of the working by that capitalists appropriate and turn into monetary profit. Marx $(1867,645)$ distinguishes two methods of surplus-value production: "The production of absolute surplus-value turns exclusively on the length of the working day, whereas the production of relative surplus-value completely revolutionizes the technical processes of labour and the groupings into which society is divided". Absolute surplus-value production means the lengthening of the unpaid part of the working day. Relative surplus-value production is the increase of productivity so that more value is produced during a certain time period than before. Engels anticipated both concepts in CWCE.

Engels gives many concrete examples of the increase of productivity through the introduction of new technologies. In the cotton industry, the invention of the jenny "made it possible to deliver more yarn than heretofore" (CWCE, 18). The introduction of the power-loom further increased the productivity of the English cotton industry: "In the years 1771-1775, there were annually imported into England rather less than $5,000,000$ pounds of raw cotton; in the year 1841 there were imported $528,000,000$ pounds, and the import for 1844 will reach at least $600,000,000$ pounds" (CWCE, 21). Similar productivity increases could be observed in other industries, for example the manufacturing of wool: "In 1738 there were 75,000 pieces of woollen cloth produced 
in the West Riding of Yorkshire; in 1817 there were 490,000 pieces, and so rapid was the extension of the industry that in 1854, 450,000 more pieces were produced than in 1825. In $1801,101,000,000$ pounds of wool $(7,000,000$ pounds of it imported) were worked up; in $1855,180,000,000$ pounds were worked up, of which $42,000,000$ pounds were imported" (CWCE, 22-23).

Engels describes the phenomenon of relative surplus-value production, but did not have a theoretical concept naming this process. Marx later introduced based on Engels the concepts of surplus-value and the methods of surplus-value production.

Since the middle of the $20^{\text {th }}$ century, The capitalist invention and the capitalist application of digital production technologies has led to significant increases of productivity. Just like Engels observed the impacts of technologies such as the steam-engine and the power-loom, we today can observe the effects of the digitalisation of production that has increased productivity.

\begin{tabular}{|c|c|c|c|c|c|c|c|c|c|c|}
\hline & $\begin{array}{l}\text { 1951- } \\
1960\end{array}$ & $\begin{array}{l}1961- \\
1970\end{array}$ & $\begin{array}{l}1971- \\
1980\end{array}$ & $\begin{array}{l}1981- \\
1990\end{array}$ & $\begin{array}{l}1991- \\
2000\end{array}$ & $\begin{array}{l}2000- \\
2010\end{array}$ & $\begin{array}{l}\text { 2011-2019 } \\
\text { (Canada: } \\
\text { 2018) }\end{array}$ & $\begin{array}{l}\text { Total } \\
\text { (for } \\
\text { available } \\
\text { time } \\
\text { period) }\end{array}$ & $\begin{array}{l}\text { Average an- } \\
\text { nual produc- } \\
\text { tivity growth } \\
(1970-2010)\end{array}$ & $\begin{array}{l}\text { Years it } \\
\text { takes to } \\
\text { double } \\
\text { productivity } \\
\text { (based on } \\
\text { average an- } \\
\text { nual produc- } \\
\text { tivity, 1970- } \\
2010 \text { ) }\end{array}$ \\
\hline Canada & & & 27.8 & 26.5 & 33.0 & 6.0 & 14.9 & 108.2 & 2.3 & 43.5 \\
\hline France & 47.0 & 68.5 & 42.5 & 38.7 & 43.5 & 29.4 & 9.1 & 269.6 & 3.9 & 25.6 \\
\hline Germany & & & 28.3 & 16.4 & 32.4 & 19.5 & 9.5 & 106.0 & 2.4 & 41.7 \\
\hline Italy & & & 52.6 & 32.8 & 26.4 & -0.1 & 12.6 & 124.2 & 2.8 & 35.7 \\
\hline Japan & & & 49.2 & 38.7 & 26.6 & 38.2 & & 152.6 & 3.8 & 26.3 \\
\hline UK & & & 22.5 & 45.6 & 30.5 & 31.9 & 1.4 & 132.0 & 3.3 & 30.3 \\
\hline USA & & & 19.7 & 33.6 & 42.9 & 46.7 & & 142.9 & 3.6 & 27.8 \\
\hline G7 & & & 30.1 & 32.7 & 34.6 & 33.9 & & 131.3 & 3.3 & 30.3 \\
\hline OECD & & & & & 20.1 & 34.6 & & 54.8 & 2.4 & 41.7 \\
\hline
\end{tabular}

Table 1: Total annual labour productivity growth in manufacturing in percentage, productivity is measured as labour productivity per unit labour input (in most cases gross value added in constant prices per hour worked), data source: OECD STAN

Table 1 shows productivity growth data for the G7-economies. It uses labour productivity growth as a measure of productivity. Labour productivity is a statistical measure of the gross value added (measured in constant US\$) produced per hour worked in a particular industry. It calculates labour productivity by diving the total value added in an industry during one year by the total amount of working hours in that industry. The data in table 1 shows the ten-year growth rate of labour productivity. Not all data was available, so some fields have been left undefined. In advanced capitalist countries, labour productivity has more than doubled over a time period of forty years (19702010). In the analysed national economies, it takes on average between 26 and 44 years to double the productivity of manufacturing. This was also the time when computing was introduced in manufacturing as a production technology. Capitalist digitalisation has resulted in large productivity growth in manufacturing and other industries.

Industry 4.0 is about technologies that combine the Internet of Things, Big Data, social media, cloud computing, sensors, artificial intelligence and robotics in the production, distribution and use of physical goods. The bourgeoisie has declared the fourth industrial revolution to try to automate the production, distribution, handling, repair and disposal of industrial goods such as cars (Fuchs 2018c). It hopes to increase the profit rate of the manufacturing industry. 
Engels pointed out that the capitalist shaping and use of industrial technologies turned workers into "machines pure and simple" (CWCE, 17). The capitalist shaping, development, design and use of digital technologies has contributed to forms of alienation such as the enslavement of mine workers who extract the physical resources out of which digital hardware is manufactured, long working hours in the assemblage of hardware and in the software and creative industry, an always-on-work-culture mediated by laptops, phones and tablets as means of production, precarious freelancing in the digital industries, etc.

\subsection{Absolute Surplus-Value Production at Foxconn}

Engels gives a picture of the terrible conditions that members of the working faced in England in the 1840s. One of his examples are the dress-makers in London:

They employ a mass of young girls - there are said to be 15,000 of them in all - who sleep and eat on the premises, come usually from the country, and are therefore absolutely the slaves of their employers. During the fashionable season, which lasts some four months, working-hours, even in the best establishments, are fifteen, and, in very pressing cases, eighteen a day; but in most shops work goes on at these times without any set regulation, so that the girls never have more than six, often not more than three or four, sometimes, indeed, not more than two hours in the twenty-four, for rest and sleep, working nineteen to twenty-two hours, if not the whole night through, as frequently happens! The only limit set to their work is the absolute physical inability to hold the needle another minute (CWCE, 217).

Here's another example of long working hours that Engels describes:

Other manufacturers were yet more barbarous, requiring many heads to work thirty to forty hours at a stretch, several times a week, letting them get a couple of hours of sleep only, because the night-shift was not complete, but calculated to replace a part of the operatives only. [...] The consequences of these cruelties became evident quickly enough. The Commissioners mention a crowd of cripples who appeared before them, who clearly owed their distortion to the long working hours. This distortion usually consists of a curving of the spinal column and legs (CWCE, 161-162).

What Engels analyses here is the method of absolute surplus-value production. Capitalist have the interest to make workers produce commodities for as many hours per day and per week as possible for as little wage as possible. Long hours and small wages promise high profits.

Absolute surplus-value production is also an important method of surplus-value production in 21st-century digital capitalism. In the period from 1992 until 2019, the number of agricultural workers in China decreased from 350 million to 120 million, the number of manufacturing workers increased from 180 million to 200 million, and the number of service workers went from 120 million to 440 million². Unlike economic development in Western capitalism, where the rise of the service and information industries was accompanied by the shrinking of agriculture and manufacturing, China's capitalism with Chinese characteristics (Harvey 2005, chapter 5) combines industrialisation and informatisation as simultaneous processes.

${ }^{2}$ Data source: ILO World Employment and Social Outlook, http://www.ilo.org/wesodata 
Western transnational digital corporations such as Apple, Dell, HP, and AsusTek make use of Chinese large and comparatively cheap labour force in order to export capital so that digital hardware is assembled in China by workers contracted by suppliers such as Foxconn, Pegatron, Compal Electronics, or Wistron. The goal is to increase profits by minimising labour costs.

Students \& Scholars Against Corporate Misbehaviour (SACOM) (2011) reported that workers at the Chinese factories at Foxconn, where iPhones and other hardware is assembled, faced conditions such as military drill, forced and unpaid overtime, fines such as the non-payment of wages, crowded accommodations, low wages, compulsory internships, toxic workplaces, etc. In 2010/2011, nineteen young Foxconn workers aged between 17 and 28 attempted to commit suicide by jumping from Foxconn buildings. Most of them died. They could no longer stand the terrible working conditions.

China Labor Watch $(2017,1,3)$ conducted research in order to find out how the working conditions look like in the factories of the Apple suppliers Compal, Foxconn, Green Point, and Pegatron:

In all of the four factories, weekly working hours surpassed 60 hours and monthly overtime hours surpassed 90 hours, with most overtime amounting to of 136 hours over a month. [...] Workers were required to sign an agreement to voluntarily do overtime, opt out of paying for social insurance and opt out of housing funds. These acts are blatant attempts to evade responsibilities and are clear violations against China's Labor Law. [...] Workers at Pegatron and Green Point were continuously working overtime without compensation. [...] Both excessive working hours and tremendous pressure are severe problems at Foxconn. Since 2010, there have been more than 10 suicides, indicative of the terrible working conditions and rigid management. In September 2016, [a] CLW [China Labour Watch] investigator launched another undercover investigation at Foxconn. [...] Most workers there had accumulated 122 hours of overtime each month [...], far exceeding the legal limit of 36 hours per month as per China's labor laws.

Just like the dress-makers whose labour Engels analysed in the 1840s, 21st-century digital hardware assemblage workers at Foxconn, Pegatron and other suppliers are a largely young and female workforce that is highly exploited. Capitalist hardware corporations try to make workers conduct a high number of weekly working hours for low pay and with unpaid overtime in order to minimise production costs so that these transnational corporations profits can be maximised. The Chinese manufacturing industry is part of a global capitalist system, in which transnational corporations outsource labour to Asia in order to accumulate capital by making use of the method of absolute surplus-value production. China's large working class, whose members often leave rural areas in order to find work in urban manufacturing centres, is transnational corporations' source of cheap and highly exploited labour.

\subsection{Play Labour at Google}

Engels describes a faction of the working class that was relatively privileged. These were workers whose "state of misery and insecurity in which they live now is as low as ever" (CWCE, 321). He terms these workers the labour aristocracy, "an aristocracy 
among the working-class" (engineers, carpenters, joiners, bricklayers) that has "succeeded in enforcing for themselves a relatively comfortable position" (CWCE, 321). Lenin $(1920,194)$ uses the notion of the labour aristocracy for "workers-turned-bourgeois", "who are quite philistine in their mode of life, in the size of their earnings and in their entire outlook". "They are the real agents of the bourgeoisie in the working-class movement, the labour lieutenants of the capitalist class".

Software engineers are a digital labour aristocracy. They tend to earn very high wages, which gives them a privileged position. The demand for their labour-power is very high. Although many software engineers are relatively rich money-wise, they are socially poor. They often lack social relations friendships, outside of the office. They spend most of their time in offices such as the Googleplex, where they work long hours. Many software companies want to keep them in the office by providing facilities for sports, entertainment, relaxation, etc. The Googleplex more looks like a playground than an office. In the life of software engineers, labour and play converge. Google workers are playworkers, workers for whom labour feels like play.

Google workers in comparison to ICT manufacturers have much higher wages and privileges, which also means that they are more unlikely to resist, which is, as Engels describes, typical for the labour aristocracy: "they are very nice people indeed nowadays to deal with, for any sensible capitalist in particular and for the whole capitalist class in general" (CWCE, 321).

This passage from Friedrich Engels's book The Condition of the Working Class in England in 1844 describes typical working conditions in the phase of the industrialization of capitalism: work in factories was mentally and physically highly exhausting, had negative health impacts, and was highly controlled by factory owners and security forces.

The manufacturing labour that Engels analysed in the 1840s was physically highly exhausting. Programming does not require engineers to burn lots of energy. Whereas manufacturing labour feels like toil, Google labour tends to feel like play.

Like at the time of Engels engineers, carpenters, joiners, bricklayers, in digital capitalism software engineers hold qualifications and produce goods that are in high demand and allow achieving relatively high wages and income. The poor workers who Engels portrays in CWCE as toiling in industries such as cotton and wool manufacturing, dress-making, etc. were compelled to work long hours by poverty wages and the "silent compulsion of economic relations" (Marx 1867, 899) of the labour-market that makes them starve if they don't sell their labour-power. Poverty-wages were used as a means of coercion, as a method of absolute surplus-value production. The contemporary digital labour aristocracy also faces the silent compulsion of having to sell their wages. But these wages are very high because they work in a highly productive industry that produces a key commodity - software - that plays an influential role in almost all parts of the $21^{\text {st }}$ century society. Digitalisation transforms all aspects of society, which is why software is in high demand and allows achieving high profits and commodity prices. Those who possess the key skill of knowing how to code software can therefore in turn achieve high wages. Absolute surplus-value production takes on a new form in this industry: software engineers often sign all-inclusive contracts that fixes a certain wage-sum per month without extra-pay for overtime. In the USA, the Fair US Labor Standards Act (Section 13 [a] 17) enables software corporations such as Google not to pay overtime if there is an hourly wage of at least US $\$ 27.63$. This law legally enacts absolute surplus-value production in the US software industry.

In addition, new management methods that try to blur the distinction between labourtime/spare-time and between workspace/private spaces are often used in software 
corporations in order to keep the workers in the company for long hours, which makes them work overtime and to experience the long hours they spend in their employers' premises not as alienation, but as play and fun. The result is that they work longer hours that are unpaid. Absolute surplus-value production in key sectors of $21^{\text {st }}$ century digital capitalism such as the software industry takes on the form of play labour. The first, second, and third edition of my book Social Media: A Critical Introduction contains a chapter about the critique of the political economy of Google (Fuchs 2014, chapter 6; Fuchs 2017b, chapter 6; Fuchs 2021, chapter 5). For this chapter, I analysed online forums, where Google workers report on their working conditions. I updated this analysis for each edition $(2014,2017,2021)$. The working conditions at Google stayed constant during this time: Google employees enjoy the content of their job, the perks such as free food and working for a high-reputation brand, but complain about the lack of work-life balance. When asked about working conditions at Google, they typical Google software-engineer says that "work/life balance is nearly non-existent" and one must be prepared to "work all day and night long" (Fuchs 2021, chapter 5).

Google employees enjoy the idea of working in a high-reputation company, tend to find their work tasks interesting, like the perks such as free food, but tend to complain about the long working hours, a lot of overtime, and the lack of work-life balance. Lack of work-life balance at companies such as Google mays a playful work environment that turns spare-time into unpaid labour-time.

Luc Boltanski and Ėve Chiapello (2005) speak in this context of the "new spirit of capitalism". The new spirit of capitalism is a management method and management ideology. It promises labour that is characterised by

autonomy, spontaneity, rhizomorphous capacity, multitasking (in contrast to the narrow specialization of the old division of labour), conviviality, openness to others and novelty, availability, creativity, visionary intuition, sensitivity to differences, listening to lived experience and receptiveness to a whole range of experiences, being attracted to informality and the search for interpersonal contacts (Boltanski and Chiapello 2005, 97).

Such promises "are taken directly from the repertoire of May 1968" (Boltanski and Chiapello 2005, 97). The new spirit of capitalism is a work culture of creativity, play, and fun that capital uses as new, sophisticated method of absolute surplus-value production that blurs establish distinctions and demarcations of space and time in the economy. Inspired by Boltanski and Chiapello, Eran Fisher summarises these changes in the following way:

It is therefore best understood in terms of the eradication of the distinctions between these components: between companies and the network, producers and consumers, producers and users, labor and fun, forces of production and the production process, and so forth. These established industrial demarcations (and more specifically, part and parcel of the Fordist phase of capitalism) are now overturned with the emergence of network production (Fisher 2010, 140). 


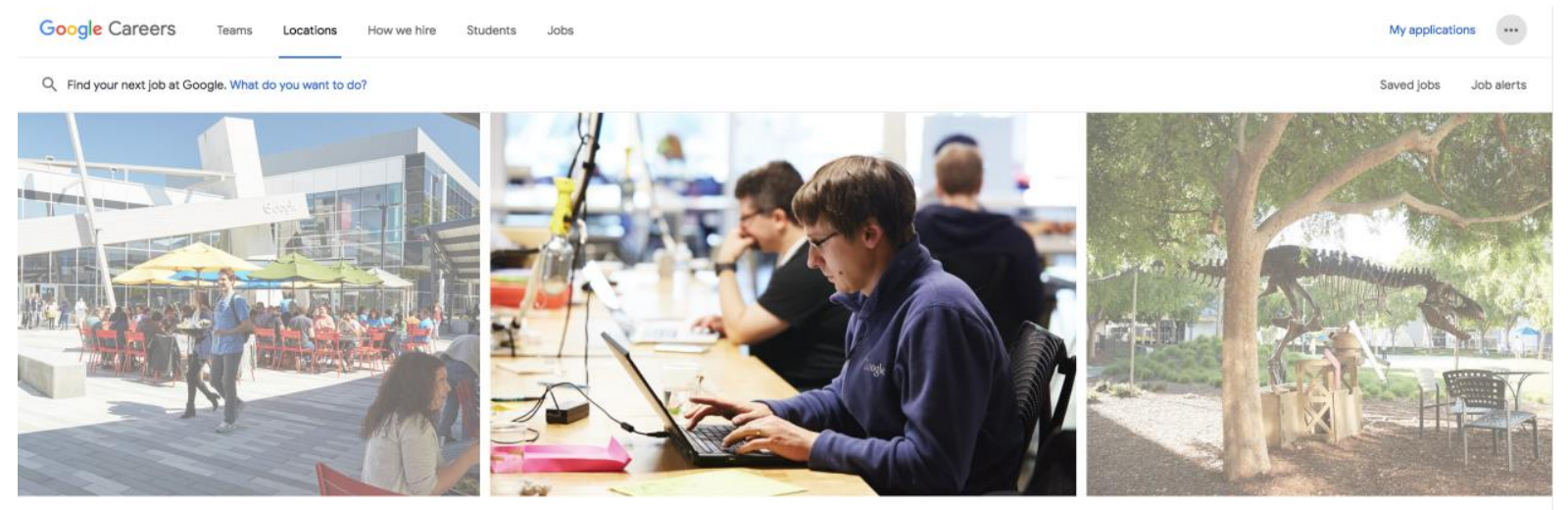

Mountain View (Global HQ)

210 jobs available

Our headquarters has come a long way from its humble roots in a Menlo Park garage, but

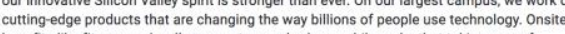

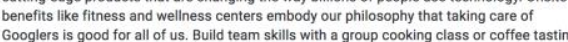

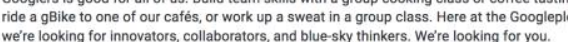

Nowalljobs

Figure 1: A Google ad for jobs at the Googleplex. Source: https://ca-

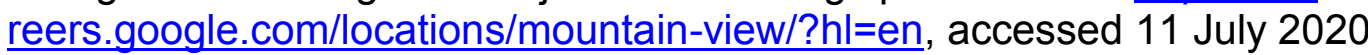

Figure 1 shows a typical Google job-ad. It advertises a variety of jobs such as software engineer, designer, business strategist, marketing, sales support, policy and privacy manager, etc. in Googleplex, the company headquarter in Mountain View, California. Google in this ad lauds itself for proving worker "[o]nsite benefits like fitness and wellness centers", "a group cooking class", "coffee tasting", riding "a gBike to one of our cafés". The business philosophy is that "taking care of Googlers is good for us all". The point is that these benefits that promise fun, relaxation and entertainment are "onsite": They keep Googlers at the Google premises and turn leisure time into labour time. When workers attend yoga and fitness classes, cooking classes, cafés etc. at the workplace, then the reproduction of their labour-power takes place at the workplace so that there is no clear spatial and temporal demarcation of labour time and relaxation. The three images in the job ad symbolise the blurring of space and time at Google: coding, chatting with colleagues in a café, a and relaxation in a garden are presented as integral parts of work at Google. Googlers do not leave the workplace for leisure time, but stay at the Google workplace. They blurring boundaries between workspace and playground and between worktime and leisure-time result in an increase of unpaid labourtime. For Google workers, lifetime becomes Google time and value-creating labourtime. What Google means by saying that "taking care of Googlers is good for us all" is that providing a playful work environment is a method of exploitation by absolute surplus-value production that is good for Google's profits.

\subsection{Precarious Platform Workers}

Digital capitalism has also given rise to platform workers. These are workers who mostly are freelancers and use apps and Internet platforms for finding work. Examples are the Uber and DiDi taxi driver, the Deliveroo biker who delivers food, and the online freelancer who uses platforms such as Fiverr, Upwork, or Freelancer for finding work. All of these platforms have in common that they are large capitalist corporations that own a proprietary software programme that platform workers use in order to find customers. The platform is a key means of production that is privately owned by digital corporations. Without access to this platform, the freelancers cannot find customers. They depend on this means of production. Formally speaking they are self-employed, but in reality they are workers who are exploited by digital platforms that control the 
key means of production as private property and capital. For each service organised via the platform, the capitalist platform corporation typically charges a share of the service price. It makes profit by renting out its platform to freelancers who produce a service commodity that is sold to customers that are found via the platform's algorithms. Platform capitalists typically advertise their platforms as enabling flexible work that allows workers to earn lots of money. Figures 2 and 3 show two examples.

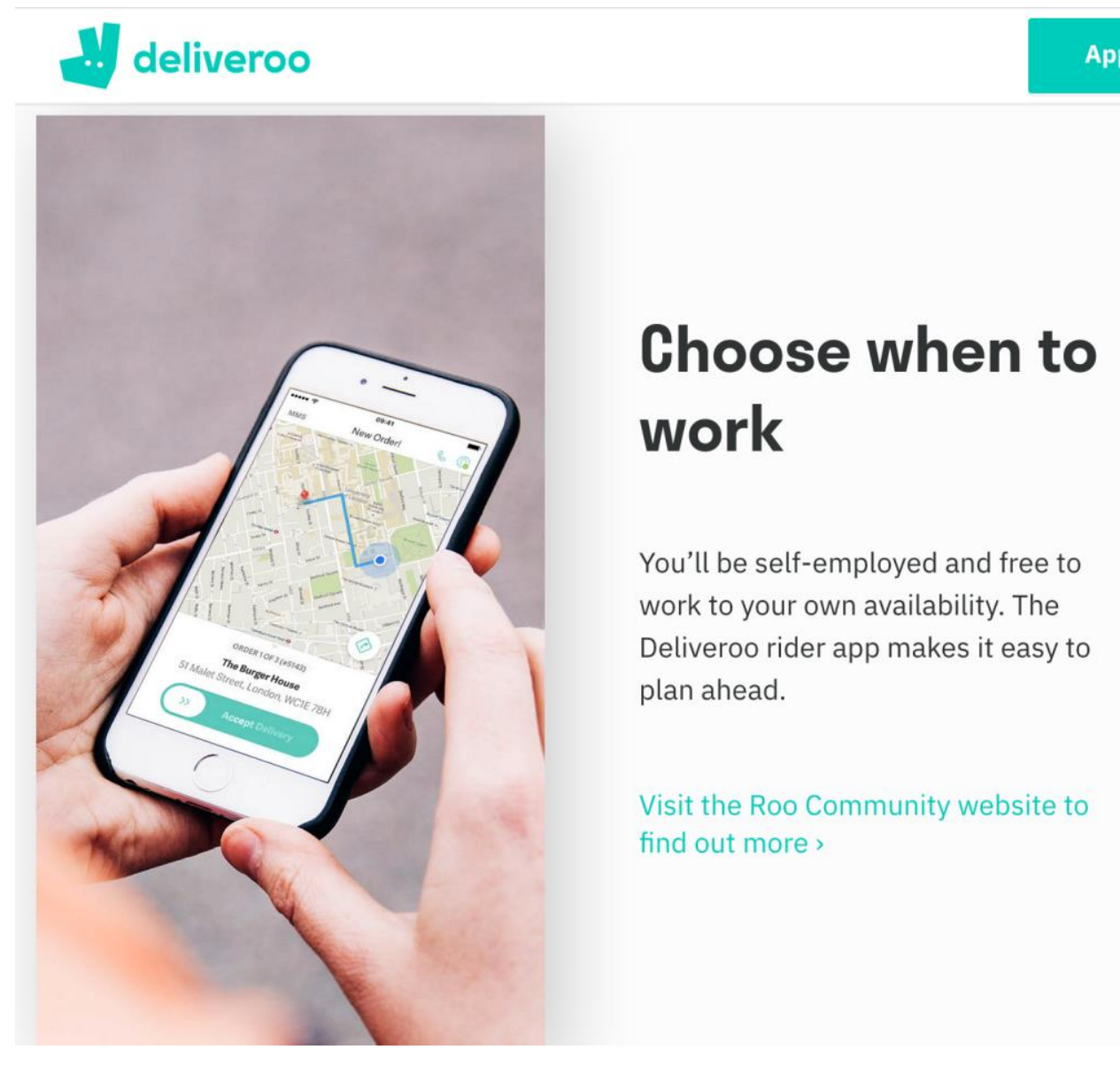

Figure 2: Deliveroo's self-presentation as platform that enables workers' freedom. Source: https://deliveroo.co.uk, accessed 11 July 2020 


\section{Make money when you want}

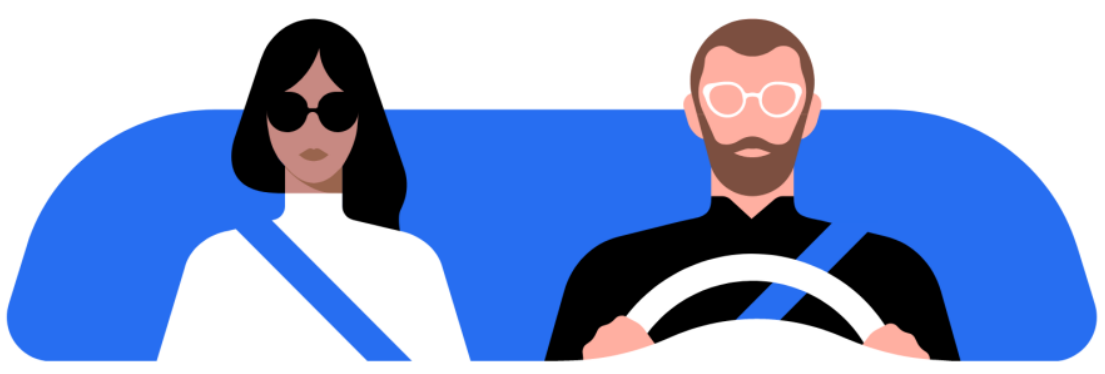

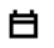

Set your own schedule

You're the boss. You can drive with the Uber app day or night. Fit driving around your life, not the other way around. $\square$

Make money on your terms

The more you drive, the more money you can make. When demand is higher than normal, you can make even more.
무

Let the app lead the way

Just tap and go. You get turn-by-turn directions and $24 / 7$ support.

Figure 3: Uber's self-presentation as platform that enables workers' freedom. Source: https://www.uber.com/at/en/drive/, accessed 11 July 2020

The common narrative of these self-presentations is that freelancer platforms enable and support workers' freedom to be their own boss and determine their work times themselves, and in doing so earn lots of money. The reality is that platform workers are very often highly exploited, precarious workers who work long hours to survive (see Fuchs 2021, chapters 11 \& 12; Fuchs 2017b, chapter 10).

Platform workers are often piece-workers. They are not paid by the hour, but for each completed service, each piece of work. Karl Marx (1867) dedicates chapter 21 in Capital Volume 1 to piece-wages (see also Fuchs 2016, chapter 21). He characterises piece-work and piece-wages as the most fruitful source of reductions on wages, and of frauds committed by the capitalists" (Marx 1867, 694). Platform labour is a contemporary form of piece-labour and piece-wages in digital capitalism that aims at platform capitalists' reduction of investment costs for maximising profits. If platforms such as Uber had to pay its drivers per hour, it might make much less profit than it does when charging a percentage share of the piece-price. Platform capitalism is a dimension of digital capitalism that advances highly precarious labour.

In CWCE, Engels describes the working conditions of needlewomen, who were paid per piece. They were low-paid and conducted highly tiresome labour. "With the same cruelty, though somewhat more indirectly, the rest of the needle-women of London are exploited. The girls employed in stay-making have a hard, wearing occupation, trying to the eyes. And what wages do they get? I do not know; but this I know, that the middleman who has to give security for the material delivered, and who distributes the work among the needle-women, receives $1 \frac{1}{2} \mathrm{~d}$. per piece" (CWCE, 218). In digital capitalist society, transnational digital corporations such as Uber, Deliveroo, Fiverr, or Upwork are the contemporary middlemen that exploit digital pieceworkers.

\subsection{Labour in the COVID-19 Crisis}

The 2020 COVID-19 crisis has resulted in radical changes of society and the economy. In many countries, societies were "shut down" in order to lower the infection risk. Many people stayed at home and worked from home. The economy and society thereby 
underwent substantial changes (Fuchs 2020b). Working at a physical distance mediated by Internet-based communication and co-operation technologies became widespread. Many knowledge and service workers, who normally conduct their work faceto-face in offices, started working at a distance from home. Workers such as academics, teachers, general practitioners, engineers, lawyers, consultants, artists, etc. became digital workers, who conduct services at a distance from their homes. Their homes became a supra-locale where working life, private life, education, leisure, etc. converged (Fuchs 2020b).

In the coronavirus crisis, being a digital worker who can work from home is a privilege that reduces the risk of unemployment, illness, and death. Other workers, especially those in the tourism industry, personal services, the hospitality industry, and the culture and entertainment industry, who cannot conduct their services from a distance, lost their jobs. Key sector workers such as food workers, supermarket workers, or health care workers, who work in industries that are absolutely essential for society, couldn't work from a distance and a shutdown of these realms of work was impossible. Because of a lack of personal protective equipment, workers in key sectors faced a much higher risk to get infected by and die from COVID-19.

Amazon's online shopping business boomed during the coronavirus-crisis. In the first financial quarter of 2020 , its revenues increased from 59.7 billion US\$ from the same period in 2019 to 75.5 billion, which is an increase by 26.5 percent $^{3}$. Amazon's stock price increased from US\$1,900 US-dollar at the start of 2020 to US\$3,200 in the middle of July $2020^{4}$. Amazon is the world's $22^{\text {nd }}$ largest transnational corporation with annual profits of US $\$ 10.6$ billion in $2019^{5}$. In 2020 . Amazon founder and CEO Jeff Bezos was with a total wealth of US\$ 113 the world's richest person ${ }^{6}$. Amazon workers are precarious service workers who according to reports faced the risk of getting infected by COVID-19:

In order to meet the demands of a country in which homes must suddenly be retrofitted to accommodate classrooms, co-working spaces, gyms, hair salons and so on, Amazon announced last month that it would hire 100,000 additional workers in its fulfillment centers and delivery networks, jobs for which many people will be desperate, given the decimated state of the retail and service industries. [...] Though the company has increased pay by $\$ 2$ an hour, employees around the country at Amazon warehouses and its subsidiary, Whole Foods, have been staging walkouts to demand better health protections during the pandemic. For years, Amazon has resisted the efforts of organized labor. [...] In a letter to Mr. Bezos, [...] labor leaders also addressed concerns that conditions at Amazon warehouses were unsafe: workers there were 'reporting crowded spaces, a required rate of work that does not allow for proper sanitizing of work spaces, and empty containers meant to hold sanitizing wipes'. [...[ various colleagues coming to work [...] [were] unwell: fatigued, lightheaded, nauseous [...] Later in the month, one of his colleagues, Barbara Chandler, tested positive for the coronavirus. She was advised by those in human resources at the facility to keep the news on the 'down low',' she told me. Frustrated by what he perceived

${ }^{3}$ Amazon Inc., SEC filings, form 10-Q for the quarterly period ending 31 March 2020, https://ir.aboutamazon.com/sec-filings

${ }^{4}$ Data source: Yahoo! Finance, https://finance.yahoo.com/quote/AMZN

${ }^{5}$ Data source: Forbes 2000 list for the year 2020, https://www.forbes.com/global2000, accessed on 11 July 2020.

${ }^{6}$ Forbes World's Billionaires List for 2020, https://www.forbes.com/billionaires/ 
as the company's lack of transparency, Mr. Smalls made it his mission to disseminate information about cases of Covid-19 at the warehouse (Bellafante 2020).

Amazon workers in countries such as the USA, France, and Italy protested against these conditions. Amazon has not released data on the number of its workers that got infected and the number of those that died. In the Amazon warehouse in Shakopee, Minnesota, 88 out of 1,000 employees got infected within 70 days (García-Hodges, Kent and Kaplan 2020).

Tönnies Holding is a German meat processing corporation that has more than 16,500 employees and. Its headquarters are in Rheda-Wiedenbrück, a town in the German state of North Rhine-Westphalia, where the company also operates a large meat processing plant. In 2018, the company achieved annual revenues of 6.65 billion Euros $^{7}$. In 2020, the wealth of Clemens Tönnies and Robert Tönnies, who are the two major owners the Tönnies Holding, was US\$ 1.8 billion each, which equally placed them as the world's $1196^{\text {th }}$ richest persons in $2020^{\circ}$. In summer 2020 , there were more than 1,500 COVID-19 cases among workers in the Tönnies factory in RhedaWiedenbrück, among them many low-paid migrant workers who are bogus self-employed and live in crowded accommodations.

The agglomeration of workers in crowded spaces played a role in the spread of COVID-19 among Tönnies-workers. A report in Der Spiegel describes the conditions that the predominantly Eastern European Tönnies-workers faced in RhedaWiedenbrück:

They tend to be hired by subcontractors, they are poorly paid, quickly replaced and inadequately protected - even during the current coronavirus pandemic. [...] Now, Clemens Tönnies - sometimes referred to as the Pork Chop Prince or the Meat Baron - has a problem. For years, he has ruthlessly pursued efficiency, but now, the entire country wants to know what goes on behind his factory gates. He has perfected the art of extracting all he can out of both his employees and the animals they process, transforming living creatures into an industrial product. His strategy was volume, volume, volume and he cut his costs to the bone, becoming the favorite supplier to Germany's discount grocery chains. The company enjoys a 30 percent share of the pork market in Germany. [...] A Polish worker in Rheda-Wiedenbrück has a bit more to say, though he is fearful of speaking openly. He says he earns 1,600 euros for 190 hours of work per month. His shifts begin at 3 a.m. and end at 1 p.m., with a 30-minute break every three hours. 'We stand at the conveyor belt about 20 to 30 centimeters apart, right next to each other. Often, the speed of the belt is ratcheted up and the supervisor watches us closely'. [...] Like the Romanians in the white-plastered house near Münster, many workers aren't actually Tönnies employees, instead working for subcontractors, and without them [...] According to Tönnies Holding, 50 percent of its workers are actually employees of such a company (Becker et al. 2014, 10-11; 11, 14)

Romanian Tönnies workers described the housing conditions they faced:

${ }^{7}$ Data source: https://toennies.de/en/home/, accessed on 11 July 2020.

${ }^{8}$ Data source: Forbes World's Billionaires List for the year 2020, https://www.forbes.com/billionaires/, accessed on 11 July 2020. 
Romanian worker: "It was always very crowded; there were sometimes 10, 12, occasionally even 14 people in one apartment. The monthly rent was 200 euros each. The buildings belonged to the subcontractors. [...] But it just isn't fair to cram so many people into one apartment!" (Deutsche Welle 2020a)

Most workers interviewed, many of whom were very upset, have been either employed by the huge meat producer Tönnies or its subsidiaries. They have described extremely exhaustive work and aggressive language. The workers accused managers of not putting enough protective measures in place in the wake of the COVID-19 pandemic. Some have also said that the shared accommodation, in which they were forced to live, was cramped and inhumane" (Deutsche Welle 2020b).

In CWCE, Engels introduces the notion of social murder, by which he means poor working conditions that endanger the lives of workers. Social murder means that workers die "indirectly, far more than directly" (CWCE, 38) through social structures that cause the death of workers and that "society places hundreds of proletarians in such a position that they inevitably meet a too early and an unnatural death, one which is quite as much a death by violence as that by the sword or bullet; when it deprives thousands of the necessaries of life, places them under conditions in which they cannot live " (CWCE, 106). Capitalism places

the workers under conditions in which they can neither retain health nor live long; that it undermines the vital force of these workers gradually, little by little, and so hurries them to the grave before their time. I have further to prove that society knows how injurious such conditions are to the health and the life of the workers, and yet does nothing to improve these conditions. That it knows the consequences of its deeds; that its act is, therefore, not mere manslaughter, but murder (CWCE, 107).

CWCE's second chapter "The Great Towns" focuses on spatial conditions of working class life. It is an analysis of everyday urban life. Engels described how in English working class districts "many human beings here lived crowded into a small space" (CWCE, 39) where there is "little air - and such air!" to breathe (CWCE, 65). 175 years after Engels published CWCE in 1845, poor working conditions and the racist exploitation of migrant workers have in the COVID-19 crisis created new forms of social murder where workers cannot keep social distance and working conditions result in COVID-19 that makes it hard for infected poor workers to breathe and results in the death of a specific share of those who caught the virus.

The Tönnies-scandal shows that 170 years after Engels's report on the conditions of the working class, poor and highly exploited workers still face threats to their health and life due to the agglomeration of many workers in cramped spaces. In the COVID19 crisis, the poorest cannot afford social distancing and are forced to risk their lives. Capital draws profits from these risks because space is considered as a production factor of capital so that crowding workers into small work and living spaces increases profitability. Tönnies makes profits by low wages for long hours. And subcontractors in addition rob parts of the workers' wages by charging high rents for overcrowded substandard accommodation. Renting out small places to extremely vulnerable workers allows rentiers to divide space into small compartments and to command a high rental price for these compartments. In addition, by keeping the compartments in a shabby 
condition, the rentier tries to keep his investment costs low in order to be able to maximise their gains.

Amazon and Tönnies are examples of companies that have been criticised by observers in the context of COVID-19. These observers have argued that workers were put at risk of catching the virus by a lack of protective measures. Work inequalities have been reinforced on the COVID-19 crisis. Migrant workers and unskilled workers are more likely to have jobs that cannot be conducted over a distance. Slaughtering animals and packing books into parcels have not-yet been fully automated and robotised. They cannot be conducted at a distance via the Internet. Low-paid, low-skill workers who cannot work from a distance have faced an increased risk of catching COVID19 and dying from the virus. In the COVID-19 crisis, social murder has taken on new forms.

\subsection{Facebook Labour}

In the book The Origin of the Family, Private Property and the State, Engels (1892, 131-132) gives a definition of materialism:

According to the materialist conception, the determining factor in history is, in the last resort, the production and reproduction of immediate life. But this itself is again of a twofold character. On the one hand, the production of the means of subsistence, of food, clothing and shelter and the implements required for this; on the other, the production of human beings themselves, the propagation of the species.

Materialism in society is the insight that social production is the key factor of all societies and social realms. What Engels's passage allows us to understand is that social production as the foundation of society is not limited to the office and the factory, but extends into all realms of society, including the family. Engels's formulation has been influential on and led to discussions in Marxist and socialist feminism (e.g. Barrett 1980, 48-49, 131-132; Eisenstein 1979; Federici 2012, 1; Fraser and Jaeggi 2018, 32; Gimenez 1987; Haug 2015; Leacock 2008, 13-29; Notz 2020; Rowbotham 1973, 47; Sayers, Evans and Redclift 1987; Vogel 1996).

Although there is besides agreement lots of criticism of Engels's formulation, its importance lies in the stress that reproductive labour such as housework is a very important aspect of capitalism. It allows a focus on the economic dimension of the household where labour-power is reproduced. Rejecting interpretations that Engels separates gender oppression from class, Martha Gimenez (1987) argues that Engels's formulation should be interpreted dialectically. "Dialectically, that is the meaning of Engels's term, 'twofold'. To speak of the twofold nature of production is to refer, at the metatheoretical level, to its fundamental moments or aspects" (Gimenez 1987, 40). Gimenez argues that Engels stresses that class and gender oppression have different and united dynamics that are interacting, interconnected and entangled through (re)production and labour.

A key insight from Engels's The Origin of the Family, Private Property and the State for understanding digital labour is that labour extends beyond the factory and the office. The political economist of communication Dallas W. Smythe (1977) stresses that audience labour is labour that produces attention for advertisements. Consumers are audience workers who create the value of the advertisement (see Fuchs 2012). Targetedadvertising based Internet platforms such as Google and Facebook make profit based on the analysis of users' online behaviour, which results in the collection of big data, 
which allows them to target ads (see Fuchs 2017; 2021). Users of Google and Facebook are unpaid digital workers, who produce Google and Facebook's value. They produce social relations, content, data, and meta-data that is appropriated by Google and Facebook and used for targeting and selling ads. Audience and user labour are like housework unpaid forms of productive, value-generating labour that operate beyond wage-labour. But housework and user labour are also quite different (for a discussion of commonalities and differences of wage-labour, slave-labour, housework, and user labour, see Fuchs 2018a). Housework produces and reproduces labour power. It is reproductive labour. Audience and user labour operate as part of entertainment as reproductive labour in the household. But audience and user labour also operate outside the home in a variety of social spaces via the use of mobile phones, laptops, tablets, etc. They facilitate the sale of commodities and the realisation of surplus-value, i.e. the generation of profit by commodity sale. Housework makes labourpower saleable on the labour commodity. User and audience labour contribute to the reproduction of labour-power via advertising-financed entertainment. These two forms of labour help selling goods on commodity markets by creating the value of ads.

Engels's The Origin of the Family, Private Property and the State has laid the foundation for the critical comprehension of the extension of the notion of productive labour beyond wage-labour and of the extension of the factory and the office into the household and onto the Internet.

\subsection{Section Summary}

Digital capitalism is based on an international division of digital labour, where a variety of workers is exploited under a variety of working conditions in different countries and working spaces so that transnational digital corporations accumulate capital. Engels in CWCE outlines concepts and analyses that can inspire digital labour analysis in the $21^{\text {st }}$ century. He shows how capital uses technology as method of relative surplusvalue production. In digital capitalism, digital technologies constitute a technological paradigm that advances new forms of automation and rationalisation of labour that have resulted in significant productivity increases so that more capital can be accumulated in less time. Engels also points out the inhumane consequences of absolute surplus-value production, i.e. the lengthening of the working day. In digital capitalism, absolute surplus-value production takes on the form of highly exploitative Taylorist work organisation in Chinese hardware assemblage factories owned by companies such as Foxconn or Pegatron, where workers toil long hours to produce the profits of transnational digital corporations such as Apple, Dell, or HP.

In digital capitalism, one also finds a form of absolute surplus-value production in software and other companies that employ highly skilled and highly paid engineers, who are incentivised to spend long hours and their life in office complexes such as the Googleplex where the boundaries between labour/play, working time/leisure time, office/home, workers/friends and family blur. The result is that the digital labour aristocracy works very long hours and has high wages but suffers from social poverty, i.e. a lack of work/life-balance, friendships and social life outside of the workplace. Digital platform workers are what Engels and Marx characterised as piece-wage workers. Engels's concept of social murder matters for understanding how in the COVID-19 crisis, the profit imperative combined with a lack of protective measures and social distancing in capitalist corporations put low-paid, low skilled workers at risk of infection and death. Engels's stress on reproductive labour in The Origin of the Family, Private Property and the State reminds us that in capitalism there are unremunerated unpaid forms of labour, such as housework and Facebook usage, that create commodities such as 
labour-power and advertising space. In digital capitalism, we find digital houseworkers who are unpaid and highly exploited (see Jarrett 2016).

The international division of digital labour means transnational digital corporations' global outsourcing of labour in order to maximise profits. The question arises what potentials there are for working class struggles against exploitation in digital capitalism. The next section addresses this issue.

\section{Working Class Struggles in Digital Capitalism}

CWCE's chapter 8 "Labour Movements" analyses the role of working class struggles in capitalism. In this chapter, Engels identifies and analyses different types of working class struggles: a) crime, b) the destruction of machinery, c) trade unions, and d) political movements.

Engels stresses that there are different ways of how workers react to their exploitation. "To escape despair, there are but two ways open to him [the worker]; either inward and outward revolt against the bourgeoisie or drunkenness and general demoralization. And the English operatives are accustomed to take refuge in both", which resulted in "hundreds of uprising against machinery and the bourgeoisie" (CWCE, 149). At the time when Engels wrote CWCE, struggles of the working class were particularly focused on the introduction of the ten hours working day. Engels again and again refers to these struggles (CWCE, 179, 182-185, 242, 313). Such struggles resulted in the introduction of the Ten Hours Bill 1847 that limited the working day for women and teenagers to a maximum of ten hours.

Engels sees crime as purely individual reaction and the destruction of machinery as limited to one single dimension of capital's rule. He propagates the unity of economic class struggles and political class struggles. He argues for the "union of Socialism with Chartism, the reproduction of French Communism in an English manner". In digital capitalism, there is a large number of different cybercrimes, crime that is committed using digital technologies such as the Internet (see Wall 2007 for an overview discussion of cybercrime). Many Internet users every day receive spam and online scams via e-mails, which are the most widely spread forms of cybercrime. Such forms of cybercrime are not the reactions of a disenfranchised working class, but highly profitable capitalist businesses.

Machine breaking means the resistance against the introduction of machinery and "revolts against machinery" (CWCE, 222). In industrialising England, machine breaking was known as "Luddism", a movement named after its founder Ned Ludd. "This form of opposition also was isolated, restricted to certain localities, and directed against one feature only of our present social arrangements" (CWCE, 222). In the book The Making of the English Working Class, the Marxist historian E. P. Thompson (1966) makes a more positive assessment of the Luddite movement than Engels (see also Fuchs 2016, 2000-2004). He writes that Luddism was not a blind attack on machinery as end-initself, but a well-organised movement that attacked the machines of capitalists that laid off workers (Thompson 1966, 564). Luddism was a working class struggle for "a democratic community, in which industrial growth should be regulated according to ethical priorities and the pursuit of profit be subordinated to human needs" (Thompson 1966, 552).

In digital capitalism, one can again and again hear suggestions and see initiatives that call for stopping to use digital technologies. An example is digital detoxing, the conscious choice to stop using digital technologies for certain periods of time. The problem of such strategies is that they often are technophobic and techno-deterministic. They see digital technologies as such as the cause of stress, health problems, 
depression, loneliness, etc. They abstract from the capitalist, class and power relations that shape contemporary digital technologies. Digital detox retreats have turned into a new form of capital accumulation, where stressed digital workers pay for switching off their phones and laptops for a weekend or a week. For example, the three-day digital detox retreat at The Detox Barn in Suffolk (UK) costs $£ 415$ per person "for three nights (Friday - Monday) including all meals, two yoga sessions, smoothie demos, guided country walks and guided meditation" ${ }^{2}$. Deceleration, digital detox and digital Luddism are capital accumulation strategies. They advance the very cause of the stress and problems that digital workers suffer - capitalism.

Engels "was the first socialist to highlight the importance of trade unions to the struggle for socialism, and this fundamental insight was the concrete corollary of his historical humanism" (Blackledge 2019, 42). Trade unions aim at raising wages and "protecting the single working man against the tyranny and neglect of the bourgeoisie" (CWCE, 223). The strike is the union's main method of struggle by which they harm capitalists whose capital is "idle as long as the strike lasted, and his machinery would be rusting" (CWCE, 225). The capitalist antagonism between capital and labour is one about the control of the means of production and working time. The capitalist wants to make the workers conduct as much unpaid labour-time as possible, whereas the workers have the interest to control all of their labour-time themselves and not to be controlled by capitalists and managers. A strike disrupts labour-time. Workers stop to work. Necessary and surplus labour time are both zero. No value is created. No commodities are produced. Capitalists make no profit.

Engels writes about the emergence of a "New Unionism" (CWCE, 324), new trade unions of unskilled workers. These trade unions differed from the old unions of skilled workers focused on wage increases because unskilled workers often faced unemployment and no wages at all. In digital capitalism, we need digital trade unions that support digital workers in uniting in struggles against digital capital.

Digital socialism begins and develops through class struggles of digital workers. The working class has changed. There are a lot of digital workers in an international digital division of labour. Class struggles in the 21st century must look different than in the 19th and 20th centuries, as the forms and places of work have changed. Many freelancers work in the digital industry. They are not capitalists, but members of the working class. Most of them only own a computer as a means of production, no monetary capital. They do not hire other workers either. They work sporadically and precariously. And they are very difficult to reach and organize in trade unions. Co-working spaces provided free or cheaply by unions create spaces where digital workers come together and can be social spaces and starting points for union organising.

Traditional trade unions have problems with the representation and organisation of atypical workers such as freelancers. Some unions do not even intend to represent freelancers because they consider them to be capitalists. As the world of work has changed, trade unions and their strategies must change if they want to advance the interests of the working class. It is of particular importance that trade unions as well as left, socialist and communist parties and movements deal with precarious work, domestic work, unemployment, consumer work, public work, Facebook user work, digital work, digital surveillance, etc. and defend and represent these forms of work.

With the convergence of production and consumption, some consumer issues have become labour rights issues. Trade unions and left, socialist and communist parties

${ }^{9}$ https://queenofretreats.com/retreats/the-detox-barn-suffolk-uk/, accessed on 12 July 2020. 
and movements should therefore consider digital consumer issues as labour rights issues and start to join forces with consumer protection associations.

The unions have lost influence and power, which means that the power of capital has been strengthened in class struggles. If the labour movement and trade unions do not succeed in engaging and organising on issues such as digital work, domestic work, unpaid work, freelance work, crowdsourcing, platform work, consumer work, work of internet users, privacy, digital surveillance, consumer protection, slave labour, etc., and if they do not see these issues as key to labour struggles, these movements commit suicide. To challenge the power of global capital requires the global networking of the working class and the internationalization of trade unions, left movements, socialist parties and trade union membership.

Class struggles are of course already taking place in digital capitalism. One example is strikes by Uber-riders. They are digital workers exploited by the Uber corporation, which controls the Uber app as a means of production. In a lawsuit in Britain it was confirmed that Uber-drivers have the legal status of workers.

Worker self-control means that the workers gain control over the app and its source code. For example, if the digital courier workers unionise with software engineers, an alternative app could be created. A strike by digital workers at Uber, Deliveroo, etc. would then consist of, for example, using the union app for one week instead of the capitalist app and damaging the capitalist companies during this period, for example to push through demands for a minimum wage of 15 Euros per hour for platform workers. Such a strike is a new form of class struggle in and against digital capital.

In digital capitalism, strikes need to add new digital dimensions of struggles in order to be effective. On the one hand, given that lots of news consumption and everyday communication takes place via social media, unions and labour movements should be present on social media and should mobilise and organise via social media and communicate their goals using hashtags, video platforms, social networking sites, messenger apps, blogs, memes, digital images, digital animations, etc. On the other hand, digital corporations such as Google, Facebook, and Amazon accumulate capital online, which is why digital strikes against such companies should make use of usersboycotts', which helps disrupting these corporations profit-making and allows putting pressure on them when making demands. An example of the digital strike is Adbuster's \#OccupySiliconValley, a one-day digital strike against Facebook, Amazon, Apple, and Google that took place in September 2018. It called on users not to use these platforms for one day. Given that online usage of platforms such as Facebook and Google is not just consumption but also labour, a Facebook- and Google-boycott is also a labour strike. The digital workers put their eyeballs to rest or direct them elsewhere, which disrupts digital value creation. The campaign call read:

Big Tech competes for one thing: our attention. They exploit our basic human instincts in the pursuit of unprecedented financial and cultural control. [...] You can turn September 17th into DO NOTHING DAY [....] Partake in a one-day embargo against tech altogether. [...] On September $17^{\text {th }}$, each one of us, in our own sweet way, will participate in a global takedown of Big Tech! [...] Make the Internet ours again ${ }^{10}$.

In respect to political struggles, Engels was a supporter of the Chartist movement, a political reform movement that struggled for suffrage and was associated with the English working class movement. Engels writes that the Chartists "wish to put a proletarian

${ }^{10}$ http://abillionpeople.org/occupy-silicon-valley/, accessed on 11 July 2020. 
law in the place of the legal fabric of the bourgeoisie" (CWCE, 235). Chartism was for Engels a "class movement" that aimed at "Chartist democracy" (CWCE, 242). Already in this early work by Engels, it becomes evident that he did not understand communism as a totalitarian state but as a democratic socialist society. Consequently, Marx and Engels in the Manifesto of the Communist Party spoke of communism as "the struggle for democracy"11 (Marx and Engels 1848a, 481).

The struggle for the reduction of the working day is the practical combination of economic and political struggles. In England, the 1847 Ten Hours Bill was the result of the combination of the socialist, the union and the Chartist movement. In the 1860s, the First International, in which Marx and Engels were key figures, formulated the demand of "eight hours work as the legal limit of the working day" (International Working Men's Association 1868, 5).

In 1919, the International Labour Organization passed the Hours of Work (Industry) Convention and in 1930 the Hours of Work (Commerce and Offices) Convention that defines the standard working week as not exceeding 48 hours per week and eight hours a day. In 2020, 52 countries had passed the first convention and 30 the second. Given there are 193 member states of the United Nations, it is evident that only a rather low number of countries has signed these international conventions. The prevalence of temporary work, zero hours contracts, part-time work, freelance labour, etc. shows that labour-time remains a key dimension of the class antagonism between capital and labour in the $21^{\text {st }}$ century.

In 2020, the digital productive forces are developed to a high degree so that labourtime could be significantly reduced and everyone could work fewer hours but lead a better life. But digital technologies are embedded into what Marx and Engels termed the antagonism between the productive forces and the relations of production.

In the Communist Manifesto, they speak of the "revolt of modern productive forces against modern conditions of production" in capitalist society "that has conjured up such gigantic means of production and of exchange" and "is like the sorcerer, who is no longer able to control the powers of the nether world whom he has called up by his spells" (Marx and Engels 1848b, 489). In digital capitalism, the antagonism between the digital productive forces and capitalist relations of production takes on the form of an antagonism between digital capital and the digital commons. On the one hand, there are new forms of capital accumulation in the digital industries that combine a variety of digital commodities and digital labour. On the other hand, there are new forms of the digital commons - such as not-for-profit online platforms, non-commercial news media, Wikipedia, the free and open source software, non-commercial Creative Commons, platform co-operatives, the free software movement, radical open access, etc. - that go beyond digital capital and practically question capital accumulation. The antagonism between the digital machines and class relations has advanced the radical asymmetrical distribution of labour-time. Whereas some workers are highly stressed, have no leisure time and work very long hours, others are unemployed, underemployed, or precarious workers. The productive forces enable a substantial reduction of the standard working day that allows a more symmetrical distribution of labour time and a good life for all. Establishing a reduction of the working week without wage cuts requires class struggles for radical reforms of labour legislation. Just like the labour movement struggled for first for the ten-hours- and then for the eight-hours-working day, in digital capitalism we need struggles for the five-hours-working day and a four-day-working

11 Translation from German: „die Erkämpfung der Demokratie“ 
week with full wage compensation. Such struggles point towards a post-scarcity society, in which digital technologies are used to minimise necessary labour time and maximise free time and the good life for all.

Writing in 1845, Engels says that a "mass of Acts for enclosing and cultivating commons is passed at every session of Parliament" (CWCE, 287). Communism "does away with all class antagonisms" (CWCE, 301). In the early phase of capitalism, common land was enclosed and peasants were forced into wage-labour. Marx (1867) terms this phase primitive accumulation. But primitive accumulation never ended. It continues in the form of imperialism, attempts of capital to make use of violence and other means for turning non-commodified spheres of society and nature into realms of capital accumulation. That is why digital capital seeks to colonise non-capitalist spaces such as the digital commons and turn them into spheres of digital capital accumulation. Engels pointed out that non-capitalist alternatives are possible and needed. For example, in the realm of media and education he argues that radical media and education are important intellectual means of struggle. He saw the Chartist newspaper Northern Star as "The only sheet which reports all the movements of the proletariat" (CWCE, 232). He stressed the importance of educational institutions such as the Chartist institutions where "the children receive a purely proletarian education, free from all the influences of the bourgeoisie" and one finds "reading-rooms" with "proletarian journals and books" (CWCE, 245).

We need concrete utopias of digital socialism. I see two potentials: On the one hand, the renewal of the movement of co-operatives and self-managed companies in the form of platform co-operatives, i.e. Internet platforms that are self-managed by users and digital workers. On the other hand, the creation of public Internet platforms through a network of public media.

Examples of platform co-operatives are the music platform Resonate, Fairbnb (an alternative to Airbnb), Taxiapp (an alternative to Uber), the photo platform Stocksy and the cooperation platform Loomio (Fuchs 2021, chapters 12, 14, \& 15). Many platform $\mathrm{co}=$ operatives do not make it from concept to reality and many soon disappear again . Those that do exist usually remain small and insignificant, so they cannot challenge the digital capital. The Marxist social scientist Marisol Sandoval (2019) analyses how some of the platform co-operatives use the capitalist language and logic of "shareholders", "profits", "investments", "creators", "entrepreneurs", "innovation", etc., thus displacing radical politics.

Socialism is neither an app nor a platform. It cannot be downloaded from the Internet or clicked on a mobile phone. It is not enough to organise platforms as co-operatives. In order to survive and create a better society, platform co-operatives must politicise themselves and act as part of radical social movements that fight collectively and politically against capitalism and for socialism. Socialism is not an app and not a platform, but a political movement. Sandoval (2016a; 2016b; 2019) argues that platform co-operatives should play an important role in this movement and that we need class struggle co-operatives. By class-struggle co-operatives Sandoval means that co-operatives become parts of socialist movements fighting for redistribution, capital taxation and socialism. They are part of what Bhaskar Sunkara (2019) calls class-struggle social democracy, whereby social democracy is to be understood in the sense of Luxembourg as a democratic socialist movement and party.

In order to prevent a new fascism it is necessary to defend and renew democracy. Public media should play an important role in this. They are non-capitalist because they are not profit-oriented. And they can only act critically and as public media if they are not controlled by the state, i.e. they are not state media. The strengthening of non- 
capitalist media is an aspect of the class struggle in so far as the power of the capitalist media is pushed back. But today we see that right-wing forces are attacking the public media and would like to abolish them. One strategy against this is the renewal of the public media in the Internet age.

There are initiatives like Public Open Space (https://public-open-space.eu) and discussions about the need for public media and international networks of public media as operators of public internet platforms. For example, a public YouTube, jointly operated by the BBC, ARD, ORF, etc., on which the archive material of the public media is offered with Creative Commons licenses for remixing for non-commercial purposes (Fuchs 2017c; 2018b; 2018d). Or a new edition of the legendary debate format Club 2 of the Austrian Broadcasting Corporation (ORF) in the form of an Internet-based Club 2.0 , in order to counter the lack of debate culture that prevails in mediatised, digital capitalism. The principle of Club 2 was that it was a live discussion without censorship, without advertising and with open air time. Club 2 was a public sphere.

In today's highly accelerated capitalism there is hardly any time and space for complex arguments and debates. The acceleration logic of capital has also colonized culture, leading to the acceleration and boulevardisation of the public sphere. More and more experiences are squeezed into short time spans, leaving hardly any time for reflection and reflected discussion. The result is the boulevardisation of the media. Reality TV is one example of this. In my opinion, Hartmut Rosa (2013) correctly points out the alienated aspects of acceleration. It is crucial in this respect to see that acceleration under capitalism is driven by the logic of accumulation.

Club 2.0 is the digital public sphere in the age of user-generated content and social media (Fuchs 2017c; 2018b; 2018d). We need to strengthen and update the independence of public media from the state and capital and empower them to act as operators of digital platforms on the Internet and to use these platforms for further developing public service media's remits.

Concrete utopias of digital socialism need concrete initiatives and projects that should be part of broader movements and struggles for socialism and the rescue and strengthening of the commons and the public sphere.

In CWCE, Engels gave significant attention to working class struggles. One can draw important lessons from Engels's insights for the analysis of digital working class struggles. Engels stresses the importance of trade unions, strikes, and radical political reforms as aspects of class struggles. In digital capitalism, we need new forms, strategies and methods of trade unions and class struggle. $21^{\text {st }}$ century society trade unions need to take serious housework, freelancers, the unemployed, platform labour and other forms of digital labour, the tendency of production and consumption to converge, digital surveillance, etc. In digital capitalism, many consumer rights issues are labour rights issues. In digital capitalism, strikes need to add new digital dimensions of struggles in order to be effective. There are two implications: First, class struggles and strikes should make use of digital platforms as means of organisation, mobilisation and communication. Second, strikes should also take place online and disrupt value production on digital platforms in order to exert digital power against digital capital. Engels stresses that questions of labour time are an important aspect of working class struggles. In 21st-century digital capitalism, the digital productive forces are so highly developed that the struggle for a five hour-working day and a four hour-working week is a realistic and necessary demand for improving the quality of life of the working class that today suffers from the precarity caused by the antagonism between the digital productive forces and the capitalist relations of production. Engels stressed the need 
for alternatives to capital and capitalism. In digital society, platform co-operatives, digital commons projects and public service Internet platforms are concrete digital utopias that point beyond digital capital(ism). Such projects and demands to implement and support them should be part of struggles for a good life for all and $21^{\text {st }}$ century socialism.

\section{Conclusion}

Engels' $200^{\text {th }}$ anniversary is an excellent occasion for the analysis of life and the conditions of the working class in digital capitalism. This article contributed to this task by dealing with the question: How relevant are Friedrich Engels's works in the age of digital capitalism?

This paper showed that Friedrich Engels's works remain highly relevant in $21^{\text {st }}$ century society and can inform the critical analysis of digital capitalism, technology and society, computational social science, digital positivism, digital labour, digital labour struggles, and the digital commons.

It is a mistake to assume that Engels is to blame for Stalinism and was the first vulgariser of Marx. But it is also an error to assume that his works are flawless. There are problematic, deterministic formulations in his works. But by and large he has stressed the importance of class struggles in and against capitalism and that the basic social law of society is that humans make their own history based on and shaped by given conditions. Engels did not formulate a theory of the automatic collapse of capitalism. Scientific socialism is not a natural science theory of society, but an anti-positivist dialectical social analysis the uses the dialectics of subject/object, agency/structures, practices/conditions, experience/reason, empirical research/social theory, chance/necessity, discontinuity/continuity, disorder/order, diversity/unity, individual/society, local/global, spontaneity/organisation, etc.

Let us summarise the main findings of this article:

\section{- Scientific socialism:}

Scientific socialism doesn't mean that society is governed by mechanical laws, but that socialist research studies society based on the combination of critical social theory and critical empirical social research. For Engels just like for Marx, there is a difference between natural dialectics and societal dialectics. The basic law of society is that humans make their own history under given conditions. In class society, class and social struggles are the processes, by which humans make their own history.

- The critique of computational social science as digital positivism:

In the contemporary social sciences, computational social sciences have emerged as a dominant paradigm that attracts lots of attention, support, and funding. Engels understood scientific socialism as a critique of positivism. Computational social science is a digital positivism that poses the danger of turning the social sciences into administrative, instrumental, positivist research that supports domination and exploitation. It neglects that qualitative features of society such as motivations, norms, moral values, feelings, ideologies, experiences, love, death, freedom, or (in)justice that cannot be reduced to quantities and computation.

- The international division of digital labour:

Digital capitalism is based on an international division of digital labour, where a variety of workers is exploited under a variety of working conditions in different coun- 
tries and working spaces so that transnational digital corporations accumulate capital. The international division of digital labour means transnational digital corporations' global outsourcing of labour in order to maximise profits. Engels in The Condition of the Working Class in England outlines concepts and analyses that can inspire digital labour analysis in the $21^{\text {st }}$ century.

- The antagonism between the digital productive forces and the capitalist relations of production:

Engels shows how capital uses technology as method of relative surplus-value production. In digital capitalism, digital technologies constitute a technological paradigm that advances new forms of automation and rationalisation of labour that have resulted in significant productivity increases so that more capital can be accumulated in less time. Digital capitalism is shaped by the antagonism between the digital productive forces and the capitalist relations of production. In $21^{\text {st }}$ century digital capitalism, the digital productive forces are so highly developed that the struggle for a five hour-working day and a four hour-working week is a realistic and necessary demand for improving the quality of life of the working class that today suffers from the precarity caused by the antagonism between the digital productive forces and the capitalist relations of production. Engels stresses that questions of labour time are an important aspect of working class struggles.

- The exploitation of digital labour:

Engels points out the inhumane consequences of absolute surplus-value production, i.e. the lengthening of the working day. In digital capitalism, absolute surplusvalue production takes on the form of highly exploitative Taylorist work organisation in Chinese hardware assemblage factories owned by companies such as Foxconn or Pegatron, where workers toil long hours to produce the profits of transnational digital corporations such as Apple, Dell, or HP. In digital capitalism, one also finds a form of absolute surplus-value production in software and other companies that employ highly skilled and highly paid engineers, who are incentivised to spend long hours and their life in office complexes such as the Googleplex where the boundaries between labour/play, working time/leisure time, office/home, workers/friends and family blur. The result is that the digital labour aristocracy works very long hours and has high wages but suffers from social poverty, i.e. a lack of work/life-balance, friendships and social life outside of the workplace. Digital platform workers are what Engels and Marx characterised as piece-wage workers.

- The social murder of workers in the COVID-19 crisis:

Engels's concept of social murder matters for understanding how in the COVID-19 crisis, the profit imperative combined with a lack of protective measures and social distancing in capitalist corporations put low-paid, low skilled workers at risk of infection and death. Engels's stress on reproductive labour in The Origin of the Family, Private Property and the State reminds us that in capitalism there are unremunerated unpaid forms of labour, such as housework and Facebook usage, that create commodities such as labour-power and advertising space. In digital capitalism, we find digital houseworkers who are unpaid and highly exploited.

- The Condition of the Working Class in England (CWCE):

In CWCE, Engels gave significant attention to working class struggles. One can draw important lessons from Engels's insights for the analysis of digital working class struggles. 


\section{- Trade unions in the digital age:}

Engels stresses the importance of trade unions, strikes, and radical political reforms as aspects of class struggles. In digital capitalism, we need new forms, strategies and methods of trade unions and class struggle. $21^{\text {st }}$ century society trade unions need to take serious housework, freelancers, the unemployed, platform labour and other forms of digital labour, the tendency of production and consumption to converge, digital surveillance, etc. In digital capitalism, many consumer rights issues are labour rights issues.

\section{- Digital working class struggles:}

In digital capitalism, strikes need to add new digital dimensions of struggles in order to be effective. There are two implications: First, class struggles and strikes should make use of digital platforms as means of organisation, mobilisation and communication. Second, strikes should also take place online and disrupt value production on digital platforms in order to exert digital power against digital capital.

\section{- Alternatives to digital capitalism:}

Engels stressed the need for alternatives to capital and capitalism. In digital society, platform co-operatives, digital commons projects and public service Internet platforms are concrete digital utopias that point beyond digital capital(ism). Such projects and demands to implement and support them should be part of struggles for a good life for all and $21^{\text {st }}$ century socialism.

In The Housing Question, Engels (1872, 324-325) argues:

And it is precisely this industrial revolution which has raised the productive power of human labour to such a high level that - for the first time in the history of mankind - the possibility exists, given a rational division of labour among all, of producing not only enough for the plentiful consumption of all members of society and for an abundant reserve fund, but also of leaving each individual sufficient leisure so that what is really worth preserving in historically inherited culture - science, art, forms of intercourse, etc. - may not only be preserved but converted from a monopoly of the ruling class into the common property of the whole of society, and may be further developed.

Computing has helped creating foundations for a highly productive post-scarcity socialist society, where wealth for all is possible and culture is the common property of the whole of society. Writing in the $19^{\text {th }}$ century, Engels wrote of science, art (and more general forms of intercourse) as aspects of culture that in socialism benefit all. Today, he would also include digital technologies such as the Internet and would demand the creation of digital commons. If Engels were alive today, he would criticise all digital capital accumulation models and argue that digital technologies shouldn't be capital and commodities but common properties available without payment to the whole of society and benefiting everyone. Engels would certainly support the creation of a public service and commons-based Internet (see Fuchs 2021, chapters 14 \& 15).

200 years after Friedrich Engels's birth, capitalism is alive, but Marx and Engels are not dead. They are ghosts that keep on haunting capitalism in the digital age in the form of class struggles and critical class analysis. Engels is a representative of a "dynamic, humanist, and creative" (Blackledge 2019, 242) critique of the political economy of capitalism. Engels's $200^{\text {th }}$ birthday reminds us of the class character of digital capitalism and that we need critical digital social science as a new form of scientific socialism. 


\section{References}

Barrett, Michèle. 1980. Women's Oppression Today. Problems in Marxist Feminist Analysis. London: Verso.

Becker, Markus et al. 2020. Corona in the Slaughterhouse: The High Price of Cheap Meat. Der Spiegel, 26 June 2020, https://www.spiegel.de/international/business/corona-in-theslaughterhouse-the-high-price-of-cheap-meat-a-ad16d0df-c1c8-4f82-93df-573fdc2c8bd6

Bellafante, Ginia. 2020. "We Didn't Sign Up For This”: Amazon Workers on the Front Lines. The New York Times, 3 April 2020, https://www.nytimes.com/2020/04/03/nyregion/coronavirus-nyc-chris-smalls-amazon.html

Blackledge, Paul. 2019. Friedrich Engels and Modern Social and Political Theory. Albany, NY: State University of New York Press.

Boltanski, Luc and Ėve Chiapello. 2005. The New Spirit of Capitalism. London: Verso.

Carver, Terrell. 1990. Friedrich Engels: His Life and Thought. New York: St. Martin's Press.

Carver, Terrell. 1983. Marx and Engels Their Intellectual Relationship. Brighton: Wheatsheaf Books.

Carver, Terrell. 1981. Engels. A Very Short Introduction. Oxford: Oxford University Press.

China Labor Watch. 2017. A Year of Regression in Apple's Supply Chain. Pursuing Profits at the Cost of Working Conditions. New York: China Labor Watch.

Cioffi-Revilla, Claudio. 2014. Introduction to Computational Social Science. Principles and Applications. London: Springer.

Conte, Rosaria et al. 2012. Manifesto of Computational Social Science. The European Physical Journal Special Topics 214: 325-346.

Deutsche Welle. 2020a. Germany: Former Abattoir Worker 'Heard Colleagues Cry at Night'. Deutsche Welle, 25 June 2020. https://www.dw.com/en/germany-former-abattoir-workerheard-colleagues-crying-at-night/a-53943595

Deutsche Welle 2020b. Germany: Romanian Workers Reveal Dire Conditions at Slaughterhouses. Deutsche Welle, 3 July 2020. https://www.dw.com/en/germany-meat-industryconditions/a-54033187

Eisenstein, Zillah. 1979. Developing a Theory of Capitalist Patriarchy and Socialist Feminism. In Capitalist Patriarchy and the Case for Socialist Feminism, ed. Zillah Eisenstein, 540. New York: Monthly Review Press.

Engels, Friedrich. 1925. Dialectics of Nature. In Marx \& Engels Collected Works (MECW) Volume 25, 311-588. London: Lawrence \& Wishart.

Engels, Friedrich. 1894. Letter to Borgius. 25 January 1894. https://www.marxists.org/archive/marx/works/1894/letters/94 01 25.htm

Engels, Friedrich. 1892. The Origin of the Family, Private Property and the State. In the Light of the Researches by Lewis H. Morgan. In Marx \& Engels Collected Works (MECW) Volume 26, 129-276. London: Lawrence \& Wishart.

Engels, Friedrich. 1888. Ludwig Feuerbach and the End of Classical German Philosophy. In Marx \& Engels Collected Works (MECW) Volume 26, 353-398. London: Lawrence \& Wishart.

Engels, Friedrich. 1880. Socialism: Utopian and Scientific. In Marx \& Engels Collected Works (MECW) Volume 24, 281-325. London: Lawrence \& Wishart.

Engels, Friedrich. 1878. Anti-Dühring. Herr Eugen Dühring's Revolution in Science. In Marx \& Engels Collected Works (MECW) Volume 25, 5-309. London: Lawrence \& Wishart.

Engels, Friedrich. 1872. The Housing Question. In Marx \& Engels Collected Works (MECW) Volume 23, 317-391. London: Lawrence \& Wishart.

Engels, Friedrich. 1845. The Condition of the Working Class in England. Oxford: Oxford University Press.

Engels, Friedrich. 1843. Outlines of a Critique of Political Economy. In Marx \& Engels Collected Works (MECW) Volume 3, 418-443. London: Lawrence \& Wishart. 
Federici, Silvia. 2012. Revolution at Point Zero: Housework, Reproduction, and Feminist Struggle. Oakland, CA: PM Press.

Fisher, Eran. 2010. Media and the New Capitalism in the Digital Age. The Spirit of Networks. New York: Palgrave Macmillan.

Fraser, Nancy and Rahel Jaeggi. 2018. Capitalism: A Conversation in Critical Theory. Cambridge: Polity.

Fuchs, Christian. 2021. Social Media: A Critical Introduction. London: Sage. Third edition.

Fuchs, Christian. 2020a. Communication and Capitalism. A Critical Theory. London: University of Westminster Press. https://doi.org/10.16997/book45

Fuchs, Christian. 2020b. Everyday Life and Everyday Communication in Coronavirus Capitalism. tripleC: Communication, Capitalism \& Critique 18 (1): 375-399. DOI: https://doi.org/10.31269/triplec.v18i1.1167

Fuchs, Christian. 2018a. Capitalism, Patriarchy, Slavery, and Racism in the Age of Digital Capitalism and Digital Labour. Critical Sociology 44 (4-5): 677-702.

Fuchs, Christian. 2018b. Digitale Demokratie und Öffentlich-Rechtliche Medien. In ORF Public Value Studie 2017/2018: Der Auftrag: Demokratie, 94-138. Wien: ORF. https://zukunft.orf.at/show content.php?sid=147\&pvi id=1986\&pvi medientyp=t\&oti tag=studie

Fuchs, Christian. 2018c. Industry 4.0: The Digital German Ideology. tripleC: Communication, Capitalism \& Critique 16 (1): 280-289. DOI: https://doi.org/10.31269/triplec.v16i1.1010

Fuchs, Christian. 2018d. The Online Advertising Tax as the Foundation of a Public Service Internet. London: University of Westminster Press. DOI: https://doi.org/10.16997/book23

Fuchs, Christian. 2017a. From Digital Positivism and Administrative Big Data Analytics Towards Critical Digital and Social Media Research! European Journal of Communication 32 (1): 37-49.

Fuchs, Christian. 2017b. Social Media: A Critical Introduction. London: Sage. Second edition.

Fuchs, Christian. 2017c. Towards the Public Service Internet as Alternative to the Commercial Internet. ORF Texte No. 20 - Öffentlich-Rechtliche Qualität im Diskurs, 43-50. Vienna: ORF.

Republication: Fuchs, Christian. 2018. Towards the Public Service Internet as Alternative to the Commercial Internet. In Public Open Space: Zur Zukunft öffentlich-rechtlicher Medien, ed. Konrad Mitschka and Klaus Unterberger, 301-307. Vienna: Facultas.

Fuchs, Christian. 2016. Reading Marx in the Information Age. A Media and Communication Studies Perspective on "Capital Volume I". New York: Routledge.

Fuchs, Christian. 2014. Social Media: A Critical Introduction. London: Sage. First edition.

Fuchs, Christian. 2012. Dallas Smythe Today - The audience Commodity, the Digital Labour Debate, Marxist Political Economy and Critical Theory. Prolegomena to a Digital Labour Theory of Value. tripleC: Communication, Capitalism \& Critique 10 (2): 692-740.

Fülberth, Georg. 2018. Friedrich Engels. Köln: PapyRossa.

García-Hodges, Ahiza, Jo Ling Kent, and Ezra Kaplan. 2020. Amazon Warehouse in Minnesota Had More Than 80 COVID-19 Cases. NBC News, 24 June 2020, https://www.nbcnews.com/tech/tech-news/amazon-warehouse-minnesota-had-more-80covid-19-cases-n1231937

Gimenez, Martha. 1987. Marxist and Non-Marxist Elements in Engels's Views on the Oppression of Women. In Engels Revisited. New Feminist Essays, eds. Janet Sayers, Mary Evans and Nanneke Redclift, 37-56. London: Tavistock.

Harvey, David. 2005. A Brief History of Neoliberalism. Oxford: Oxford University Press.

Haug, Frigga. 2015. Gender Relations \& The Marx Within Feminism. In Marxism and Feminism, edited by Shahrzad Mojab, 33-101. London: Zed.

Hegel, Georg Wilhelm Friedrich. 1830/1991. The Encyclopaedia Logic (with the Zusätze). Part I of the Encyclopaedia of the Philosophical Sciences with the Zusätze. Indianapolis, IN: Hackett. 
Hobsbawm, Eric J. 1969. Introduction. In Friedrich Engels: The Condition of the Working Class in England: From Personal Observation to Authentic Sources, 7-17. London: Panther.

Horkheimer, Max. 1947. Eclipse of Reason. New York: Continuum.

Hunt, Tristam. 2009. Marx's General. The Revolutionary Life of Friedrich Engels. New York: Metropolitan Books.

International Working Men's Association. 1868. Resolutions of the Congress of Geneva, 1866, and the Congress of Brussels, 1868. London: Westminster Printing Company.

Jarrett, Kylie. 2016. Feminism, Labour and Digital Media: The Digital Housewife. New York, NY: Routledge.

Kopf, Eike. 2017. Marxismus ohne Engels? Köln: PapyRossa.

Krätke, Michael. 2020. Friedrich Engels oder: Wie ein "Cotton-Lord" den Marxismus erfand. Berlin: Dietz.

Kurz, Heinz D. 2020. Der junge Engels über die „Bereicherungswissenschaft“, die „Unsittlichket“ von Privateigentum und Konkurrenz und die „Heuchelei der Oekonomen“. In Arbeiten am Widerspruch - Friedrich Engels zum 200. Geburtstag, ed. Rainer Lucas, Reinhard Pfrim and Hans-Dieter Westhoff, 65-120. Marburg: Metropolis.

Lazer, David et al. 2009, Computational Social Science. Science 323: 721-723.

Leacock, Eleanor Burke. 2008. Myths of Male Dominance. Collected Articles on Women Cross-Culturally. Chicago, IL: Haymarket Books.

Lenin, Vladimir Ilyich. 1920. Preface to the French and German Editions of "Imperialism, the Highest Stage of Capitalism". In Lenin Works Volume 22, 189-194. London: Lawrence \& Wishart.

Levine, Norman. 2018. Engels' Co-option of Lenin. In The Palgrave Handbook of Leninist Political Philosophy, ed. Tom Rockmore and Norman Levine, 161-199. Basingstoke: Palgrave Macmillan.

Levine, Norman. 2006. Divergent Paths. Hegel in Marxism and Engelism. Volume 1: The Hegelian Foundations of Marx's Method. Oxford: Lexington Books.

Levine, Norman. 1975. The Tragic Deception. Marx Contra Engels. Oxford: Oxford University Press.

Lukács, Georg. 1971. History and Class Consciousness. London: Merlin.

Marx, Karl. 1867. Capital. Volume I. London: Penguin.

Marx, Karl. 1863. Marx to Engels, 9 April 1863. In Marx \& Engels Collected Works (MECW) Volume 41, 466-469. London: Lawrence \& Wishart.

Marx, Karl. 1859. A Contribution to the Critique of Political Economy. Preface. In Marx \& Engels Collected Works (MECW) Volume 29, 261-265. London: Lawrence \& Wishart.

Marx, Karl. 1857/58. Grundrisse. London: Penguin.

Marx, Karl 1852. The Eighteenth Brumaire of Louis Bonaparte. In Marx \& Engels Collected Works (MECW) Volume 11, 99-197. London: Lawrence \& Wishart.

Marx, Karl. 1844. Ökonomisch-philosophische Manuskripte aus dem Jahr 1844. In Marx Engels Werke (MEW) Band 40, 465-588. Berlin: Dietz.

Marx, Karl \& Friedrich Engels. 1848a. Manifest der Kommunistischen Partei. In Marx Enge/s Werke (MEW) Band 4, 459-493. Berlin: Dietz. S. 462-463.

Marx, Karl and Friedrich Engels. 1848b. The Manifesto of the Communist Party. In Marx \& Engels Collected Works (MECW) Volume 6, 477-519. London: Lawrence \& Wishart.

Marx, Karl and Friedrich Engels. 1845. The Holy Family, or Critique of Critical Criticism. Against Bruno Bauer and Company. In Marx \& Engels Collected Works (MECW) Volume 4, 5-211. London: Lawrence \& Wishart.

Mayer, Gustav. 1935. Friedrich Engels. A Biography. London: Chapman \& Hall.

McLellan, David. 1993. Introduction. In Friedrich Engels: The Condition of the Working Class in England, ix-xx. Oxford: Oxford University Press.

Notz, Gisela. 2000. Auseinandersetzung mit Friedrich Engels' „Ursprung der Familie ...“ ... und was er uns heute noch zu sagen hat. In Arbeiten am Widerspruch - Friedrich Engels 
zum 200. Geburtstag, ed. Rainer Lucas, Reinhard Pfrim and Hans-Dieter Westhoff, 397416. Marburg: Metropolis.

Rosa, Hartmut. 2013. Social Acceleration. A New Theory of Modernity. New York: Columbia University Press.

Rowbotham, Sheila. 1973. Woman's Consciousness, Man's World. Harmondsworth: Penguin.

Sandoval, Marisol. 2019. Entrepreneurial Activism? Platform Cooperativism Between Subversion and Co-optation. Critical Sociology, DOI: https://doi.org/10.1177/0896920519870577

Sandoval, Marisol. 2016a. Fighting Precarity with Co-operation? Worker Co-operatives in the Cultural Sector. New Formations 88: 51-68.

Sandoval, Marisol. 2016b. What Would Rosa Do? Co-operatives and Radical Politics. Soundings: A Journal of Politics and Culture 63: 98-111.

Sayers, Janet, Mary Evans and Nanneke Redclift, eds. 1987. Engels Revisited. New Feminist Essays. London: Tavistock.

Schmidt, Alfred. 1971. The Concept of Nature in Marx. London: NLB.

Stalin, Joseph V. 1945. Dialectical and Historical Materialism. In History of the Communist Party of the Soviet Union, 105-131. Moscow: Foreign Languages Publishing House.

Students \& Scholars Against Corporate Misbehaviour (SACOM). 2011. iSlave Behind the iPhone: Foxconn Workers in Central China. http://sacom.hk/wp-content/uploads/2018/10/2011-iSlave-Behind-the-iPhone-Foxconn-Workers-in-Central-China.pdf (accessed on 21 October 2019).

Sunkara, Bhaskar. 2019. The Socialist Manifesto: The Case for Radical Politics in An Era of Extreme Inequality. London: Verso.

Thompson, Edward P. 1966. The Making of the English Working Class. New York: Vintage Books.

Vogel, Lise. 1996. Engels's Origin: Legacy, Burden and Vision. In Engels Today. A Centenary Appreciation, ed. Christopher J. Arthur, Basingstoke: Macmillan. 129-151.

Wall, David S. 2007. Cybercrime: The Transformation of Crime in the Information Age. Cambridge: Polity.

Zimmermann, Clemens. 2020. Die Lage der arbeitenden Klasse in England. In Friedrich Engels: Ein Gespenst geht um in Euopa. Begleitband zur Engelsausstellung 2020, ed. Lars Bluma, 70-83. Remscheid: Bergischer Verlag.

\section{About the Author}

Christian Fuchs

Christian Fuchs is a critical theorist and the co-editor of tripleC: Communication, Capitalism \&

Critique (http://www.triple-c.at). http://fuchsc.net, @fuchschristian 


\title{
Engels's Theory of Social Murder and the Spectacle of Fascism: A Critical Enquiry into Digital Labour and its Alienation
}

\author{
Aishik Saha \\ Independent Researcher, Kolkata, India, aishikjadavpur1994@gmail.com
}

\begin{abstract}
In this paper, I shall attempt to respond to the charge that the digital labour theory, as developed by Christian Fuchs, doesn't faithfully stick to the Marxist schema of the Labour Theory of Value by arguing that Marx's critique of capitalism was based on the social and material cost of exploitation and the impact of capitalist exploitation of the working class. Engels's analysis of The Condition of The Working Class in England links the various forms of violence faced by the working class to the bourgeois rule that props their exploitation. I shall argue, within the framework of Critical Social Media Studies, that the rapid advance of fascist and authoritarian regimes represents a similar development of violence and dispossession, with digital capitalism being a major factor catalysing the rifts within societies. It shall be further argued that much like the exploitative nature of labour degrades social linkages and creates conditions of that exaggerates social contradictions, the "labour" performed by social media users degenerates social relations and promotes a hyper-violent spectacle that aids and abets fascist and authoritarian regimes.
\end{abstract}

Keywords: digital labour, society of the spectacle, fascism, filter bubbles, alienation

Acknowledgement: Criticisms and suggestions provided by Dr. Utsa Ray, Assistant Professor at Jadavpur University, Department of History, and Ayan Chandra, researcher at IITKharagpur, have been extremely helpful with writing this paper.

\section{Introduction}

This paper will attempt at a convergence of multiple trajectories of critical research in social media studies. Starting with an analysis of the concept of digital labour it will be argued that rethinking contemporary debates is required in the light of the developments in $\mathrm{Al}$ and machine learning over the past decades. We will then attempt to understand Engels's conception of alienation from a Marxist-Humanist perspective, and attempt to locate the alienation of digital labour within this framework. Next, we will look at recommender systems and the role of alienated digital labour in the development of its algorithms, and the development of filter bubbles that lead to echo chambers of right-wing opinion. Finally, our analysis of these echo-chambers and the role of social media brings us to the society of the spectacle as defined by Guy Debord, where social relations are distorted by the violence of the spectacle.

\section{A Critical Rethinking of Digital Labour}

The emergence of Critical Social Media Studies and the concept of digital labour have attracted its fair share of critiques. The main issue that these critiques share is the rather unorthodox categorisation of labour and subsequently its view of exploitation. In order to develop an understanding of the concept of digital labour, we must look at the definition of labour itself, especially in its relation to the overall Marxist 
framework within which the concept has been formulated. It is also important to look at the types of labour actually being engaged by users rather than simply pigeonholing them into pre-existing categories of labour.

The commodity has two distinct aspects, use-value and exchange-value, which are of a contradictory nature (Marx 1867; Marx 1865). The use-value of a commodity refers to the utility of the commodity, and can only be realised in either use or consumption (Marx 1867, 126). The exchange-value of a commodity, on the other hand, refers to the quantitative relation in which use-values of one kind can exchange for use-values of another. In a class society, exchange-value is itself created through the use of labour-power, which must then be reproduced. Marx $(1867,320)$ divides this labour-power into necessary labour, i.e. labour that creates all the necessary values for the reproduction of labour-power, and surplus-labour, i.e. labour that creates surplus-value over and above what is necessary for the reproduction of labour-power. This divides work-time into the categories of necessary labour-time and surplus labour-time with surplus valu' being created from the latter. Capitalists seek to maximise the production of surplus value, either by increasing the total work-time (which can be done by mainly extending the length of the workday) or decreasing the duration of the necessary labour-time, which is then taken up by surplus labour-time (which can mainly be done by introducing more productive technology).

The theoretical underpinnings of digital labour lie in rethinking the concepts of value and abstract labour as simultaneous expressions of political economy and socio-political class struggle (Fuchs 2014). Fuchs and Sevignani (2013) outline the the Hegel-Marxist triangle model of work, which is then employed to develop the concept of digital work, which defines communication itself as a form of work. This approach however negates the concept of immaterial labour involved in the production of the cultural content of a commodity (Hardt and Negri 2004; Lazzarato 1996). Fuchs $(2014,252)$ has argued that information work is material itself, and is intrinsically linked to the materiality of work and thus doesn't require a distinct categorical marker. Dallas Smythe (1977b) argues that the development of what he calls the consciousness industry represents an encroachment of the leisure time of workers through the use of advertisements. He develops the concept of the audience commodity, where the labour-power of workers is sold as a commodity through the medium of advertisements (Smythe 1977a; 1977b). The conditions under which this sale of labourpower takes place are distinct from the commonly known form of the exchange of value, as the working audience is both the subject and the object of this transaction. The audience performs the labour of learning about the particular brand, and is thus responsible for the creation of demand for that particular commodity within the domain of monopoly capitalism (Smythe 1977b). Thus, the process of reproduction of labour-power in itself is congealed into the audience labour performed by the workers/audience. In order to understand digital labour, the concept of the audience commodity is modified into the concept of the Internet prosumer commodity (Fuchs 2014, 93-94). Digital labour follows the trajectory set by the concept of audience labour, with users being both producers of content as well as its main consumers, while at the same time generating a surplus-value of Internet prosumer commodities, which can then be sold to advertisers (Fuchs 2013).

In the book Culture and Economy in the Age of Social Media, Fuchs (2015) outlines the major debates surrounding digital labour, so for our purposes we will briefly take a look at the critiques of the application of Marx's theory of value to digital labour. James Reveley (2013) has argued for the abandonment of the concept of digital labour in favour of a Marxist pursuit of social media's influence on labour-power. 
The argument he makes is that the overall framework of the Labour Theory of Value that Marx has espoused is not strictly adhered to, especially the relation between necessary labour and surplus labour. He also negates Smythe's concept of the audience commodity on the basis of the same objection. The same rejection of the Marxist theorisation of value forms the basis of the criticism by Arvidsson and Colleoni (2012). Rather than the sale of a prosumer commodity, "any discussion of value needs to take into account the central role finance plays in the appropriation and distribution of value" (Arvidsson and Colleoni 2012, 136). Kaan Kangal's critique argues that user information is already a commodity before it enters the Internet and thus users cannot be said to produce value, and argues that Fuchs' "exploitation thesis dislocates the source of profit made by media companies from selling the advertisement rights to the value production of Internet users" (Kangal 2016, 7). Bolaño and Vieira (2015) on argue that the concept of the audience commodity remains a valid analytical tool, but say that the idea of users performing labour needs to be criticised. They argue: "What is sold by Google, by the way, is not the users themselves [...] because the advertiser does not buy any individual users or even their singular information. Advertisers buy only an amount of data about a target audience based on categories, as we have outlined" (Bolaño and Vieira 2015). A similar approach is shared by Robinson, who argues that advertising on the Web 2.0 actually helps "realize value produced elsewhere" rather than being the source of surplus-value itself (Robinson 2014, 50).

The confusion regarding the role and labour of Internet users is primarily due to the diversity of the types of activity and the ways in which Web 2.0 functions. Christoph Raetzsch (2016) raises this issue by pointing out to the diverse ways in which different websites like Facebook, Twitter, Instagram, as well as search engines like Google or online encyclopaedias like Wikipedia work. The inability to perform a differential diagnosis of the rate of profit is the main reason that many of the critics of the theory of digital labour refuse to analyse it within a Marxist framework (Reveley 2013; Arvidsson and Colleoni 2012). In treating data as a pre-existing use-value, as emphasised by the metaphors of oil and coal, the interaction between users and social media platforms as experience is overlooked (World Economic Forum 2012; Raetzsch 2016). However, Interactive Machine Learning (IML) has introduced us to a different conceptualisation of digital labour. Defined as "the science of getting computers to realize a task without being explicitly programmed", Machine Learning has essentially automated the task of developing algorithms for mining through data (Rocca 2019). Not only do the users provide data, they are, in this model, actually performing the labour of training algorithms. This point is stressed by Amershi et al. $(2014,106)$ who point out that in contrast to conventional machine learning, "model updates in IML are more rapid (the model gets updated immediately in response to user input), focused (only a particular aspect of the model is updated), and incremental (the magnitude of the update is small; the model does not change drastically with a single update). This allows users to interactively examine the impact of their actions and adapt subsequent inputs to obtain desired behaviors. As a result of these rapid interaction cycles, even users with little or no machine-learning expertise can steer machine-learning behaviors through low-cost trial and error or focused experimentation with inputs and outputs". The participation of networked communities like those of social media can boost the incremental nature of updates to a more dynamic one. Within the IML model, the users definitely do perform labour, which leads to updates of algorithms and an overall advancement of the recommender systems. The advances in machine learning through user inputs means that users are also participat- 
ing in the process of alienation. Dead labour is in this manner being used to appropriate labour-power, which represents the classic Marxist confrontation between labour and capital. Understanding this alienation is thus crucial to understanding the way in which digital labour is transforming contemporary capitalism.

\section{Engels and Marxist Humanism}

Our conception of exploitation cannot however be satisfied with a mechanistic understanding of exploitation, but rather has to look at the effects of exploitation and alienation on the working class itself. Engels's analysis in The Condition of the Working Class in England (1845b) provides an understanding of the capitalist exploitation of the industrial working class in $19^{\text {th }}$ century England. Engels laid the ground for the critique of the political economy of capitalism. In this section, we shall interrogate the role of digital labour and its forms of alienation, and its impact on the socio-historical process, especially by analysing the Marxist Humanism of Friedrich Engels.

The question of alienation features prominently here and we must deal with it briefly before proceeding. Gajo Petrović $(1963,421)$ summarises Marx's views:

Marx begins with the alienation of the results of man's labor, alienation of objects produced by man. The realization of labor is its objectification, and this objectification is for the laborer at the same time the loss of object, alienation. To the product of his labor the worker is related as to an alien object. Products of his hands constitute a separate world of objects which is alien to him, which dominates him, and which enslaves him.

Dead labour, which is capital, can only survive by extracting living labour, and thus the relationship between capital and labour is perennially antagonistic. Marx (1844) points out in the Economic and Philosophic Manuscripts of 1844 that there are four stages of alienation that occur within a class society:

- The alienation of a person's own labour, and subsequently the alienation of the products of their labour.

- The alienation of the process of production, which ensures that productive activity results in the subjugation of the worker rather than their freedom.

- The alienation of the worker, who is a creative being, from their creative ability. By depriving a worker of their creative ability, Marx opines that the process alienates the worker from their humanity itself.

- The alienation of humans from their own species being. The relationship between humans is distorted by the prism of class society, i.e. the contemporary capitalist society.

The final point leads us to an understanding of commodity fetishism where relationships between commodities become a determinant for social relationships between humans. The alienated labour therefore goes on to dominate the worker, who has performed the labour to produce it. Finally the increasing accumulation of capital enables the displacement of the worker into the ranks of the unemployed reserve army of labour. Thus, the greater amount of labour workers perform, the more they contribute to their own alienation and oppression.

Engels has, over the past century, been dogged by the tag of being a vulgar materialist, in one form or the other, and has been posed against Marx's more Hegelian tendencies. Before we proceed to establish Engels's humanist credentials, we must 
seek to understand what Marxism's contribution to humanist philosophy has been and to what extent Marxism itself is a humanist philosophy. Donald Clark Hodges $(1965,191)$ has argued that one of Marx's critical contribution to humanism was "its addition of a material, bodily, passionate and sensuous content to traditional humanism and the elevation of this content to the status of liberal activity" and "its development of the social and humanitarian elements of traditional humanism". Raya Dunayevskaya $(1965,63)$ has in fact argued that not only is the view that Marx abandoned his early humanist philosophy false, but conversely humanism "gives Marx's magnum opus its force and direction". She points out that Marx's critique of commodity fetishism and alienation is integral to Marxism rather than simply a stepping stone to the critique of capital. A similar line of argument is forwarded by John Roche (2005) in his critique of Louis Althusser, demonstrating that Marx's critique of human alienation and human liberation draws upon Feuerbach's critique of religious alienation. He also opines that Marx champions the proletariat as he views struggling workers as agents of human liberation. In its unification of the world of sensuous and spiritual experiences Marxism seeks human liberation in the liberation from the material conditions that make such exploitation possible.

If the proletariat is viewed as the agent of human liberation, it is Engels who must be credited with recognising its crucial role, which then became a definitive aspect of both his and Marx's works. Ann Dennehy (1996) writes that the earliest works of Engels lacks a proper theoretical framework through which he could analyse his perspectives on the impoverishments that he saw. This synergy between Marx's and Engels's own inputs helps in placing the "blank face and figure of Marx's abstract proletarian" into "a real house and real factory" (Wilson 1940, 146). Engels (1845b) establishes through his Dickensian description of the living and working condition of the working class the true nature of exploitation. In his studies of the early communist colonies the contrast with the wretched conditions of the industrial working class is rather clearly presented (Engels 1845b). Engels's condemnation of the capitalist system is quite clear:

When one individual inflicts bodily injury upon another such injury that death results, we call the deed manslaughter; when the assailant knew in advance that the injury would be fatal, we call his deed murder. But when society places hundreds of proletarians in such a position that they inevitably meet a too early and an unnatural death, one which is quite as much a death by violence as that by the sword or bullet [...] (Engels 1845b, 393-394)

Engels's recognition of this social murder caused by hunger, starvation and disease, or even the precarious conditions of living that make one prone to various fatal accidents is clearly aimed at the hypocrisy of bourgeois humanism and thus seeking to extend the boundaries of humanist thought to include the industrial proletariat. These social murders are not limited to industrial towns or capitalist countries but also extend into the domains of the colonies. The multiplicity of plagues and famines in the colonies can only be explained as products of capitalist alienation. The role of alienation figures heavily as the main instrument in ensuring inequality, which in turn acts as a motivator for workers to continue participating in the system. Richard Peet (1975) points out that this hierarchical inequality needs to be recreated, which is largely achieved through a geographical uneven distribution of resources. Engels too notes that the graded inequality marks the difference between the English and Irish 
workers in England, with English workers being more disposed towards skilled work, while the Irish workers were filling the ranks of workers with less technical expertise.

Kun Wu and Qiong Nan (2020) point to the expansion of the scope of dialectics by Engels, including the critique of idealist dialectics, which led to the emergence of materialist dialectics. In Dialectics of Nature (1883), as E. San Juan Jr. (1995) argues, Engels (1883) sees motion as an inherent attribute of matter that can help us to comprehend all processes occurring in the universe including thought. This is viewed as an erasure of subjectivity in Engels's works, which denies any possibility of revolutionary action (Lukács 1971). However San Juan Jr. (1995, 412) identifies the revolutionary potential of Engels's ideas of aesthetics, which like "religion [...] is one of the fruits of the alienating division of labor". Thus, while religion is understood to be a result of the alienation of humans from their species being, aesthetics can be seen as a reflection of the alienated creative being. In Description of Recently Founded Communist Colonies, Engels (1845a) argues that once all tasks are within the community, i.e. no longer being performed for capitalist profit but rather the overall use of all community members, their menial nature itself becomes meaningless.

Digital labour confronts the prosumer by extremist online communities that are able to mobilise and inflict violence, which I propose should be included within the phenomenon of social murder. Engels's recognition of human creativity's revolutionary potential and the sources of its alienation, as well as the reproduction of this alienation, helps us place it within the framework of the humanist conception of liberation. The categorisation of social murder as a distinct feature of capitalist domination and a necessary aspect of the capitalist alienation of labour marks a major contribution to the understanding of alienation itself.

\section{The Alienation and Cyber-Balkanisation of Social Media}

It should by now be clear that digital capitalism has created its own forms of alienation, which in turn supports the development of hyper-nationalist/fascist ideologies in their wake. I shall borrow Van Alstyne and Brynjolfsson's (2005) concept of CyberBalkans in order to understand the growth of fascism in the digital era. It is necessary to explore the legitimisation of fringe discourses through social media, and the development of a distorted consciousness and the forces which help the process. This will help us understand why the internet, instead of creating a space for free exchange of views and knowledge has rather helped as the expansion of forces of bigotry.

Understanding the role played by recommender systems (RS) and the business models of social media sites is crucial to explaining the social divergence that lies at the root of the alienation caused by digital capitalism. In general RSs suggests content, denoted as items, to users based on a host of factors (Ricci, Rokach and Shapira 2011). The main task of a RS is identifying the interests of a user, whom we have identified in the paper as a prosumer, and then providing meaningful recommendations. With the rise of social media, many have sought to utilise these social linkages in developing and evaluating newer recommendation models, one such being the trust-enhanced recommendation techniques (Victor, De Cock and Cornelis 2011). Social networking sites like Facebook have provided a vast pool of data for recommender systems (Shapira, Rokach and Freilikhman 2013). In fact, the value of a recommendation is often determined by the strength of the interpersonal ties between the users (Oechslein and Hess 2014). Inputs from the user regarding their tasks through their likes, shares, and public engagement helps the recommender algorithm identify the user's interests. The platform profits from being able to target users with highly specific advertisements and thus relies on the 
accuracy of its recommendations (Curran, Graham and Temple 2011). The utilisation of social advertising through boosted collaborative filtering demonstrates that Facebook is incentivised to combine different filtering models in order to precisely target audiences (Fan and Chang 2010).

Multiple studies have shown that online communities tend to coalesce into homogeneous groups with similar views. Eli Pariser (2011) emphasises that the Internet, based on the user's previous searches and interests, can present very different pictures of the world, which he argues results in a filter bubble that makes it increasingly difficult for users to encounter dissenting opinions. Jacobson, Myung and Johnson $(2015,13)$ have pointed out that on the Facebook wall of partisan news sites "audiences have a limited number of sources they prefer to reference when discussing the news". The growth of polarised communities or echo-chambers is also highlighted by Del Vicario et al. (2016), demonstrating that the effect of polarisation increases in both scientific and conspiracy theory-based communities. The more a user engages with the community, the more polarised their opinion tends to be. In the case of Twitter, it has been demonstrated that users prefer to engage with other users of similar political views and share from sources that affirm their positions (Himelboim, McCreery and Smith 2013). Studies of the debates surrounding Brexit as well as vaccination debates have demonstrated how the polarisation process takes place on social media (Schmidt et al. 2018; Vicarioa et al. 2017). A contrary view is presented by Möller et al. (2018) and Haim, Graefe and Brosius (2018). They point out that personalised and non-personalised news usually tend to have the same diversity. However they do not seem to consider that recommendations don't only come from the recommender systems but also other users who are a part of the network of the user. The bias is thus structured into the recommender system's logic rather than one that creeps in through usage. This phenomenon of cyber-balkanisation was predicted by Van Alstyne and Brynjolfsson (2005), though they seem to have underestimated the role that increasing pressures of commercialisation on social media sites and social recommender systems may have played. One may argue that social media sites are incentivised to expose users to a limited set of content mainly based on a user's interaction with other users and their own preferences, since it is useful for advertisers to target audiences most receptive to their messages. Recommenders are thus calibrated to increasingly serve this function.

This phenomenon of cyber-balkanisation has been exemplified by the mainstreaming of extremist politics of the right over the past decade. Tania Bucher (2012) points out that APIs can articulate politics, which O'Callagan et al. (2015) point out how YouTube's recommender algorithms can articulate right wing extremist politics. The model of platform capitalism, argues Tanner Mirrlees (2019), is what has allowed the alt-right to gain the kind of currency, which would otherwise have been outside of its reach leading to the platformisation of fascism. By repeatedly exposing users to a limited but trusted source of content, far-right politics is converted into an idea being performed on a platform, which legitimises its existence in the marketplace of ideas. While television, radio and other mass media have allowed politics to be performed, social media has allowed for performances to be politicised.

Siva Vaidhyanathan (2018) highlights that social media, while purportedly supporting the spread of democracy and freedom of speech across the world, has ironically given a major platform to political and social forces that subvert such objectives. Specifically focusing on Facebook, Vaidhyanathan $(2018,8)$ points out: 
Through its destructive influence on other media firms, industries, and institutions, Facebook undermines their ability to support healthy public deliberation as well. Facebook distorts the very sources of news and information on which a democratic republic relies.

Not only does Facebook change the way we see and share news, its business model has ensured that most advertising campaigns have shifted their focus to a social media centric model, which in turn has weaned away advertisement revenue from media houses. Trevor Garrison Smith (2017) on the other hand argues that the failure of political theorists to theorise politics in the digital age has resulted in a rejection of politics from both the left and the right. Fuchs $(2018,262)$ focuses on the neoliberal framework that has given rise to the authoritarian capitalism, pointing out that neoliberalism "is a huge machine of calculation and accumulation that tries to turn everything into a commodity". Since everything has been commoditised, it goes without saying that politics itself has been commoditised, lending itself to a far greater extent to the principles of advertisement and marketing than simple political rhetoric. Facebook and other social networking sites primarily rely on algorithmic surveillance of user metadata in order to provide targeted advertisements (Doyle 2014). Much like commercial establishments, algorithmic surveillance allows political groups to target specific demographics based on recommender algorithms. The distortion thus takes place at two ends, with politics being framed increasingly to cater to digital demographics, and recipients of such politics also imagining themselves as parts of certain in-groups based on choice or identity rather than a class.

The alienation of digital labour, as with other forms of alienation, results in the alienation of the prosumer from their species-being, as we saw previously. The commodification of human creativity through social media lies at the root of this alienation. Digital labour alienated from the prosumer confronts them as an alien force by distorting the politics and society within the conditions of neoliberal capitalism. The role played by recommender systems and the creation of the filter bubble are crucial aspects of this distortion that represent a major role in the alienation of humans from their own species being, i.e. social alienation. Under these circumstances the prosumer is converted into a market demographic, with the intersection or contradiction between the two users determining their mutual interactions.

\section{Spectacular Alienation}

The notions of the spectacle and violence emerge as the key features of digital capitalism so far, and their inter-linkages must be explored to understand the process of alienation of digital labour. Guy Debord (1992) argues that the spectacle is created when the dominant mode of production invades the fabric of our social lives, where being itself becomes synonymous with having. Brad Evans and Henry A. Giroux (2015) point out that the spectacle of violence substitutes human empowerment. While we saw how alienated digital labour created the conditions for a spectacle in conditions of digital capitalism, how the spectacle creates conditions for the alienation of the prosumer class in particular and the overall working class in general remains obscured.

Debord $(1992,10)$ points out the fundamentally spectaclist nature of our modern society, underlining the power of the spectacle to subject human beings to itself is precisely due to the fact they have already been subjugated by the dominant mode of production, i.e. neoliberal capitalism. He further elaborates that given the alienating nature of the mode of production, life is identified with non-working time, i.e. leisure 
time. Here Marx's (1844) assessment of estranged labour confronting the worker as an alien force proves to be useful. Estranged labour is converted into the spectacle and performs two crucial tasks for the capitalist mode of production. On one hand, by imposing itself upon the leisure-time of the worker, it hinders the creative-ability of the worker (creative-being) by presenting celebrity-hood as the goal of social labour, while on the other hand, it falsifies social life on the basis of identities created out of trivialities, thus alienating the workers from their species-being.

The term infotainment though somewhat appropriate doesn't seem to grasp the cocktail of fear and hate that is channelised through social media, and is perhaps better exemplified as disinfotainment. Douglas Kellner (2003) points out to the multiple instances of the spectacle propagated through mass media like the OJ Simpson trial, conspiracy theories regarding alien invasions or bio-weapons, with even the presidential elections being converted into spectacles. The fact that the interplay between media and activism does play a crucial role in negotiating the visibility of dissent in the public space was noted by Bruce D'Arcus (2006), who described it as spectacles of dissent. Mohamed Nanabhay and Roxane Farmanfarmaian (2011, 574) point out that in the case of Egypt in the initial stages of the uprising against Hosni Mubarak, "citizens [were not only] able to produce their own footage but to distribute it through social networks, thus bypassing mainstream media as the traditional gatekeeper of news". In fact the role of social media throughout the Arab Spring has been widely remarked upon, as has its role in the Occupy Wall Street and other protests inspired by it. Paul Mihailidis and Samantha Viotty (2017) explored the participation of netizens in the spectacular US presidential elections of 2016, which demonstrated the fragmentation of social media discourse into closed-off echochambers and allowed for the proliferation of post-truth discourse. Hannah Arendt (1994) points out that rather than the ideologically convinced follower, the ideal subject of totalitarian rule is someone who has lost the ability to distinguish between truth and falsehood. Since all politics is reduced to a spectacle, this notion of truth and falsehood can easily be reduced to two contesting spectacles vying for dominance. Here the demand for social justice and racial equality is a spectacle to be counterpoising the demand for law and order. Similarly the narrative of environmental degradation, which is causing suffering in communities across the world is also dismissed as another spectacle, which is then confronted with the spectacle of a communist plot to dismantle capitalism in the United States. These spectacles aren't geographically or temporally restricted and find multiple manifestations in multiple conditions. The disinfotainment machine continues to manufacture these binaries, with politics and political struggle being replaced by competing spectacles.

Engels (1845c), as we previously saw, outlines the conditions in which the social murder of the working class takes place. In modern digital society, the politics of disposability creates new conditions of social murder. Henry A. Giroux (2010) refers to this as zombie politics where increasingly neoliberal policies results in the dispossession of millions of people, and are then categorised as human waste. David Harvey (2005) identifies this process of cutting down of public welfare measures while increasing the deregulation of private industry as accumulation by dispossession. This creates an increasing section of the population who are perennially exposed to the vagaries of the political economy, whom Guy Standing (2011) identifies as the precariat. Social murder in the twenty-first century takes a spectacular form, enacted on the screens of our smartphones and televisions, amplified by newsroom debates. 
The walking hyper-dead even oppose providing the extension of unemployment benefits to millions of Americans who are out of work, food, and hope. They spectacularize hatred and trade in lies and misinformation. They make populist appeals to the people while legitimating the power of the rich. They appeal to common sense as a way of devaluing a culture of questioning and critical exchange. Unrelenting in their role as archetypes of the hyper-dead, they are misanthropes trading in fear, hatred, and hyper-nationalism (Giroux 2011, 3).

In pitching human society against itself, neoliberal society no longer feels the need to justify its violence. Karen Laurie (2002) rightly identifies that the role of the news anchor has increasingly started to resemble that of a game show host, rather than a voice of reason. While the disinfotainment industry falsifies, spectacularises, and misrepresents information, the task of the anchor-host is to present both fact and fiction as equally valid. In this topsy-turvy world, the demand for free healthcare is the same as forcing doctors and nurses to work against their will. The demand for lowering of the cost of education and cancellation of burdensome education loans are the same as theft from those who have managed to pay off their loans. The demand for a living wage is a communist plot to destroy the economy. The demand for greater police accountability is encouragement to crime. Exposing war-crimes committed by American forces in Iraq or exposing the widespread surveillance of citizens is treason. The deaths caused by the lack of healthcare, police brutality, hate-crimes or imperialist wars can definitely be defined as social murders as Engels had defined the term.

Stuart Hall (1979) explores the contradictions that lead to the destruction of social democracy and allows for the emergence of authoritarian populism, leading to a new neoliberal consensus. A somewhat similar process has followed the 2007-2008 global financial crisis allowing for the emergence of a radical right focused on an antiimmigration and white nationalist rhetoric, which rejected international cosmopolitanism and the social security measures that supposedly draw the underserving immigrants to the developed economies in the West (Mirrlees 2019). Hall $(1979,14)$ points out that the general trends do not warrant overlooking the specific historical circumstances. We have seen earlier, certain studies have sought to critique the idea of the filter bubble (Haim, Graefe and Brosius 2018). However, the filter bubble exists not simply as a general phenomenon, but as a historical one in a neoliberalspectaclist society, where even exposure to opposing views can serve the purpose of further polarisation (Bail et al. 2018). The de-contextualisation of the politics behind the spectacle serves the purpose of polarisation rather than providing a holistic context to contradictions (Lyford and Payne 2005). Since, as Debord $(1992,1)$ points out, the spectacle is "a social relation between people that is mediated by images", it can be inferred that the role played by social media, presenting de-contextualised images from around the world, can only further increase fragmented views of reality. Here social media doesn't simply play the role of an amplifier of existing contradictions, but is rather an integral element of our contemporary neoliberal society. Social networking sites, in the process of prioritising their advertisement-based revenue models, ensure that recommender systems lead to filter bubbles, where fact diverges from its context and becomes a spectacle. This leads to an increase of human vulnerability to authoritarian populist manipulations, which we see happening at present. The process of de-contextualisation is in fact a powerful force that can delegitimise any narrative. Poverty without the context of the insidious but perpetual violence that gives rise to and maintains it, is simply laziness on the part of the poor to work their way out of poverty. Subsidised healthcare, food, education or other necessities can 
be constructed as free hand-outs, once we de-contextualise the very crucial task of social stability that they provide. Protests against police brutality, as we have seen recently, can be easily equated with savagery and looting, when taken out of the context of the centuries of violence against racial minorities. Slogans directed against America will seem a real threat unless seen from the perspective of decades of US involvement in imperialist wars around the world.

The alienation of the prosumer class is thus both manifested and manufactured through the spectacle. The disinfotainment industry, in its creation of multiple competing spectacles, essentially projects truth as a marketable commodity, to be malleable to the demands of the market. The blurring of the boundary between truth and falsehood creates the ideal conditions for totalitarian rule as Hannah Arendt points out. The de-contextualisation of facts lies at the root of the spectacle that mediates social relations through images. Under such conditions, violence is normalised and justified as necessary against illusory threats that are conjured by the spectacle. The grassroots mobilisation towards a totalitarian agenda enforced by violence against the most vulnerable communities mimics fascism adequately enough to be categorised into the same broad category. This social murder committed under the conditions of digital capitalism, through a withdrawal of necessary social security and increasingly violent instruments of legal coercion, is a crucial instrument in the arsenal of neoliberal capitalism in order to ensure the continued obedience on the part of the working class.

\section{Conclusion}

Our enquiries into the role played by digital labour in the process of IML, have demonstrated the process of alienation of digital labour. Machine learning algorithms represent dead labour, which can only sustain and reproduce itself by the living labour provided in the form of digital labour. The alienation of digital labour in the conditions of contemporary neoliberal capitalism leads to the creation of filter bubbles that correspond to the alienation of the worker (whom we have identified in our context as the prosumer) from their species being. The alienation from the species being is also manifested through the spectacle when the dominant mode of production completely subjugates society at large. Recommender systems have played a crucial role in the subjugation of social media to financialisation, which has been the key to the creation of filter bubbles. Finally we have discussed the growth of fascism as a product of the spectacle in society and on social media, which we have identified as social murder under the conditions of digital capitalism.

Engels's identification of social murder as an instrument of violence employed in the control of the working class becomes increasingly relevant. The most common form of social murder remains the active denial of necessities for existence like healthcare, protection against environmental calamities or degradation of health through pollutants, as even Engels had noted. This violence however is accompanied by physical and social violence.

In this country, social war is under full headway, every one stands for himself, and fights for himself against all comers, and whether or not he shall injure all the others who are his declared foes, depends upon a cynical calculation as to what is most advantageous for himself. It no longer occurs to anyone to come to a peaceful understanding with his fellow-man; all differences are settled by threats, violence, or in a law-court. In short, everyone sees in his neighbour an enemy to be got out of the way, or, at best, a tool to be used for his own ad- 
vantage. And this war grows from year to year, as the criminal tables show, more violent, passionate, irreconcilable" (Engels 1845c, 427).

The conditions of social murder thus include both "passive" and "active" violence against the most vulnerable sections of the society, and forms the bedrock of fascist violence. While Engels had anticipated that this antagonism would result in the confrontation between the Bourgeois and Proletariat, the reality of "Bonapartism" contradicted his own estimation.

While we should however avoid a simplistic equivalence between Bonapartism, as Engels described it, and our contemporary fascist movements, Bonapartism has been identified by a number of commentators as a proto-fascist movementsand was used by the Comintern as a prototype to model its analysis of fascism upon. Engels analysed the conditions of Bonapartism in the following manner:

Bonapartism is the necessary form of state in a country where the working class, at a high level of its development in the towns but numerically inferior to the small peasants in rural areas, has been defeated in a great revolutionary struggle by the capitalist class, the petty bourgeoisie and the army (Engels $1865,72)$.

Neoliberal capitalism played a major role in the defeat of the working class in our times. We have also recognised the intimate role of neoliberalism in developing digital capitalism and the subsequent use of the spectacle to dominate and control the workers. Engels attributes the rise of Bonapartism to a similar need for dominance and control over the working class. A clear and remarkable similarity emerges between the objectives and the tasks of Bonapartism and the spectaclist variety of fascism that emerges under conditions of digital capitalism. This spectaclist fascism prolongs the "social war of all against all" (Engels 1845b, 248) and continues with its historic task of perpetuating capitalist exploitation by disrupting the possibility of any extended working class solidarity, and intensifying the conditions that make social murder possible in a neoliberal society. Our analysis of digital labour has demonstrated that appropriation of prosumer labour plays a crucial role in this process.

Plainly stated, the digital labour performed by prosumers is converted into the spectaclist form of fascism and made into an instrument to control their social being. The fascist form both creates the condition of social murder and social violence through coercive apparatus of the state, ensuring the passive acceptance of the dominant mode of production and its legitimising ideology on the part of the working classes. This places us firmly within a Marxist terrain of analysis of digital labour, and demonstrates that digital labour is a distinct form of labour that can be recognised within a Marxist framework.

\section{References}

Amershi, Saleema, Maya Cakmak, William Bradley Knox, and Todd Kulesza. 2014. Power to the People: The Role of Humans in Interactive Machine Learning. Al Magazine 35 (4): 105-120.

Arendt, Hannah. 1994. The Origins of Totalitarianism. San Diego: Harcourt Brace \& Company.

Arvidsson, Adam and Elanor Colleoni. 2012. Value in Informational Capitalism and on the Internet. The Information Society 28 (3): 135-150. 
Bail, Christopher A., Lisa P. Argyle, Taylor W. Brown, John P. Bumpus, Haohan Chen, M. B. Fallin Hunzaker, Jaemin Lee, Marcus Mann, Friedolin Merhout, and Alexander Volfovsky. 2018. Exposure to Opposing Views on Social Media Can Increase Political Polarization. PNAS 115 (37): 9216-9221.

Bolaño, César R. S., and Eloy S. Vieira. 2015. The Political Economy of the Internet: Social Networking Sites and a Reply to Fuchs. Television \& New Media 16 (1): 52-61.

Bucher, Taina. 2012. Want to Be on the Top? Algorithmic Power and the Threat of Invisibility on Facebook. New Media \& Society 14 (7): 1164-1180.

Curran, Kevin, Sarah Graham, and Christopher Temple. 2011. Advertising on Facebook. International Journal of E-Business Development 26 (1): 26-33.

D'Arcus, Bruce. 2006. Boundaries of Dissent: Protest and State Power in the Media Age. New York: Routledge.

Debord, Guy. 1992. Society of the Spectacle. London: Rebel Press.

Del Vicario, Michela, Gianna Vivaldo, Alessandro Bessi, Fabiana Zollo, Antonio Scala, Guido Caldarelli, and Walter Quattrociocchi. 2016. Echo Chambers: Emotional Contagion and Group Polarization on Facebook. Scientic Reports 6: 37825, 1-12.

Dennehy, Anne. 1996. The Condition of the Working Class in England: 150 Years On. In Engels Today: A Centenary Appreciation, edited by Christopher J. Arthur, 95-128. New York: St. Martin's Press.

Doyle, Kim. 2014. Facebook, Whatsapp and the Commodification of Affective Labour. Communication, Politics \& Culture 48 (1): 51-65.

Dunayevskaya, Raya. 1965. Marx's Humanism Today. In Socialist Humanism: An International Symposium, edited by Erich Fromm, 63-76. New York: Doubleday \& Company.

Engels, Friedrich. 1883. Dialectics of Nature. In Marx \& Engels Collected Works (MECW) Volume 25, 313-590. London: Lawrence \& Wishart.

Engels, Friedrich. 1865. The Prussian Military Question and the German Workers' Party. In Marx \& Engels Collected Works (MECW) Volume 20, 37-79. London: Lawrence \& Wishart.

Engels, Friedrich. 1845a. Description of Recently Founded Communist Colonies Still in Existence. In Marx \& Engels Collected Works (MECW) Volume 4, 214-228. London: Lawrence \& Wishart.

Engels, Friedrich. 1845b. Speeches in Elberfeld. In Marx \& Engels Collected Works (MECW) Volume 4, 243-264. London: Lawrence \& Wishart.

Engels, Friedrich. 1845c. The Condition of the Working Class in England. In Marx \& Engels Collected Works (MECW) Volume 4, 295-583. London: Lawrence \& Wishart.

Evans, Brad, and Henry A. Giroux. 2015. Disposable Futures: The Seduction of Violence in the Age of Spectacle. San Francisco: City Lights Books.

Fan, Teng-Kai and Chia-Hui Chang. 2010. Learning to Predict Ad Clicks Based on Boosted Collaborative Filtering. 2010 IEEE Second International Conference on Social Computing, 209-216.

Fuchs, Christian. 2018. Digital Demagogue: Authoritarian Capitalism in the Age of Trump and Twitter. London: Pluto Press.

Fuchs, Christian. 2015. Culture and Economy in the Age of Social Media. New York: Rouledge.

Fuchs, Christian. 2014. Digital Labour and Karl Marx. New York: Routledge.

Fuchs, Christian. 2013. Digital Prosumption Labour on Social Media in the Context of the Capitalist Regime of Time. Time \& Society 23 (1): 1-27.

Fuchs, Christian and Sebastian Sevignani. 2013. What Is Digital Labour? What Is Digital Work? What's Their Difference? And Why Do These Questions Matter for Understanding Social Media? tripleC: Communication, Capitalism \& Critique 11 (2): 237-293.

Giroux, Henry A. 2011. Zombie Politics and Culture in the Age of Casino Capitalism. New York: Peter Lang. 
Giroux, Henry A. 2010. Zombie Politics and Other Late Modern Monstrosities in the Age of Disposability. Policy Futures in Education 8 (1): 1-7.

Haim, Mario, Andreas Graefe, and Hans-Bernd Brosius. 2018. Burst of the Filter Bubble? Digital Journalism 6 (3): 330-343.

Hall, Stuart. 1979. The Great Moving Right Show. Marxism Today. January: 14-20.

Hardt, Michael, and Antonio Negri. 2004. Multitude: War and Democracy in the Age of Empire. New York: The Penguin Press.

Harvey, David. 2005. A Brief History of Neoliberalism. New York: Oxford University Press.

Himelboim, Itai, Stephen McCreery and Marc Smith. 2013. Birds of a Feather Tweet Together: Integrating Network and Content Analyses to Examine Cross-Ideology Exposure on Twitter. Journal of Computer-Mediated Communication 18 (2): 40-60.

Hodges, Donald Clark. 1965. Marx's Contribution to Humanism. Science \& Society 29 (2): 173-191.

Jacobson, Susan, Eunyoung Myung, and Steven L. Johnson. 2015. Open Media or Echo Chamber: The Use of Links in Audience Discussions on the Facebook Pages of Partisan News Organisations. Information, Communication \& Society 19 (7): 1-17.

Kangal, Kaan. 2016. The Karl Marx Problem in Contemporary New Media Economy: A Critique of Christian Fuchs' Account. Television \& New Media 17 (5) 1-13.

Kellner, Douglas. 2003. Media Spectacle. New York: Routledge.

Laurie, Karen. 2002. News Anchor Or Games Show Host? Alternet, June 07. Accessed September 18, 2020. https://www.alternet.org/2002/06/news anchor or games show host/146965/

Lazzarato, Maurizio. 1996. Immaterial Labor. In Radical Thought in Italy: A Potential Politics, edited by Michael Hardt and Paolo Virno, 133-50. Minneapolis: University of Minnesota Press.

Lukács, Georg. 1971. History and Class Consciousness: Studies in Marxist Dialectics. Cambridge, MA: The MIT Press.

Lyford, Amy and Carol Payne. 2005. Photojournalism, Mass Media and the Politics of Spectacle. Visual Resources 21 (2): 119-129.

Marx, Karl. 1867. Capital. Volume I. London: Penguin.

Marx, Karl. 1865. Value, Price and Profit. In Marx \& Engels Collected Work (MECW) Volume 20, 101-149. London: Lawrence \& Wishart.

Marx, Karl. 1844. Economic and Philosophic Manuscripts of 1844. In Marx \& Engels Collected Works (MECW) Volume 3, 229-348. London: Lawrence \& Wishart.

Mihailidis, Paul and Samantha Viotty. 2017. Spreadable Spectacle in Digital Culture: Civic Expression, Fake News, and the Role of Media Literacies in "Post-Fact" Society. American Behavioral Scientist 61 (4): 1-14.

Mirrlees, Tanner. 2019. The Alt-Right's Platformization of Fascism and a New Left's Digital United Front. Democratic Communiqué 28 (2): 28-46.

Möller, Judith, Damian Trilling, Natali Helberger, and Bram van Es. 2018. Do Not Blame It on the Algorithm: An Empirical Assessment of Multiple Recommender Systems and their Impact on Content Diversity. Information, Communication \& Society 21 (7): 959-977.

Nanabhay, Mohammed, and Roxanne Farmanfarmaian. 2011. From Spectacle to Spectacular: How Physical Space, Social Media and Mainstream Broadcast Amplified the Public Sphere in Egypt's "Revolution". The Journal of North African Studies 16 (4): 573-603.

O'Callaghan, Derek, Derek Greene, Maura Conway, Joe Carthy, and Pádraig Cunningham. 2015. Down the (White) Rabbit Hole: The Extreme Right and Online Recommender Systems. Social Science Computer Review 33 (4): 459-478.

Oechslein, Oliver and Thomas Hess. 2014. The Value of a Recommendation: The Role of Social Ties in Social Recommender Systems. 47th Hawaii International Conference on System Sciences: 1864-1873.

Pariser, Eli. 2011. The Filter Bubble: What the Internet is Hiding from You. New York: The Penguin Press. 
Peet, Richard. 1975. Inequality and Poverty: A Marxist-Geographic Theory. Annals of the Association of American Geographers 65 (4): 564-571.

Petrović, Gajo. 1963. Marx's Theory of Alienation. Philosophy and Phenomenological Research 23 (3): 419-426.

Raetzsch, Christoph. 2016. Is Data the New Coal? Four Issues With Christian Fuchs on Social Media. Networking Knowledge 9 (5): 1-21.

Reveley, James. 2013. The Exploitative Web: Misuses of Marx in Critical Social Media Studies. Science \& Society 77 (4): 512-535.

Ricci, Francesco, Lior Rokach, and Bracha Shapira. 2011. Introduction to Recommender Systems Handbook. In Recommender Systems Handbook, edited by Francesco Ricci, Lior Rokach, Bracha Shapira and Paul B. Kantor, 1-35. New York: Springer.

Robinson, Bruce. 2014. With a Different Marx: Value and the Contradictions of Web 2.0 Capitalism. The Information Society 31 (1): 44-51.

Rocca, Joseph. 2019. A Simple Introduction to Machine Learning. Towards Data Science. December 23. Accessed August 22, 2020. https://towardsdatascience.com/introductionto-machine-learning-f41aabc55264

Roche, John. 2005. Marx and Humanism. Rethinking Marxism 17 (3): 335-348.

San Juan Jr., E. San Juan. 1995. The Revolutionary Aesthetics of Frederick Engels. Nature, Society, and Thought 8 (4) 405-432.

Schmidt, Ana Lucía, Fabiana Zollo, Antonio Scala, Cornelia Betsch, and Walter Quattrociocchi. 2018. Polarization of the Vaccination Debate on Facebook. Vaccine 36 (25): 36063612.

Shapira, Bracha, Lior Rokach, and Shirley Freilikhman. 2013. Facebook Single and Cross Domain Data for Recommendation Systems. User Modeling and User-Adapted Interaction 23 (2-3): 211-247.

Smith, Trevor Garrison. 2017. Politicizing Digital Space: Theory, the Internet, and Renewing Democracy. London: University of Westminster Press.

Smythe, Dallas. 1977a. Communications: Blindspot of Western Marxism. Canadian Journal of Political and Social Theory 1 (3): 1-27.

Smythe, Dallas. 1977b. Critique of the Consciousness Industry. Journal of Communication 27 (1): 198-232.

Standing, Guy. 2011. The Precariat: The New Dangerous Class. London: Bloomsbury Academic.

Vaidhyanathan, Siva. 2018. Anti-Social Media: How Facebook Disconnects Us and Undermines Democracy. New York: Oxford University Press.

Van Alstyne, Marshall and Erik Brynjolfsson. 2005. Global Village or Cyber-Balkans? Modeling and Measuring the Integration of Electronic Communities. Management Science 51 (6): 851-868.

Vicarioa, Michela Del, Fabiana Zolloa, Guido Caldarellia, Antonio Scalab, and Walter Quattrociocchi. 2017. Mapping Social Dynamics on Facebook: The Brexit Debate. Social Networks 50: 6-16.

Victor, Patricia, Martine De Cock, and Chris Cornelis. 2011. Trust and Recommendations. In Recommender Systems Handbook, edited by Francesco Ricci, Lior Rokach, Bracha Shapira and Paul B. Kantor, 645-675. New York: Springer.

Wilson, Edmund. 1940. To the Finland Station. New York: Doubleday \& Company.

World Economic Forum. 2012. Personal Data: The Emergence of a New Asset Class. WEF Report 1-40.

Wu, Kun and Qiong Nan. 2020. The Contemporary Value of Engels' Dialectics. International Journal of Systems Science and Applied Mathematics 5 (2): 12-19. 


\section{About the Author}

Aishik Saha is an independent researcher. He has obtained his M.A. in History from Jadavpur University in India. His research interests include Critical Theory, Fascisms, Comparative Politics, Global South and Colonialism. 


\title{
Digital Capitalism and Coal Mine Workers
}

\author{
Akın Bakioğlu \\ Erzincan Binali Yıldırım University, Erzincan, Turkey, akin.bakioglu@gmail.com
}

\begin{abstract}
One hundred and seventy-five years ago, in his book titled The Condition of the Working Class in England, Engels wrote about the ways in which the mine workers were exploited within the capitalist system. Classical economists believed that with the improvements in technology, capitalism would create egalitarian employment opportunities for everyone. In their opinion, the coal which served as a catalyser for the classical modernization had no place in the age of digital technology. However nowadays, especially in various developing countries such as Turkey, in the production of coal mines, the existing working conditions are the same as the ones that were applicable one hundred and seventy years ago and the exploitation of the labour of the workers continues. Notwithstanding, digital technologies serve for the control of capitalist production instead of the wellbeing of the workers. Coal has always had an important role in the historical continuity and discontinuity periods of capitalism. Considering the unbreakable link between the exploitation of nature and capitalist accumulation of capital, giving up coal and switching to renewable energy sources does not seem possible. The dialectical link between technology consumption and technology production is also one of the most important reasons for coal production to continue. This article argues that in Turkey today, the technology used in coal mine craft prioritises the control of labour rather than prioritizing the working comfort of the mine workers.
\end{abstract}

Keywords: digital capitalism, mine workers, space mining, coal production.

\section{Introduction}

The aim of this paper is to discuss the relationships between digital capitalism and coal mining. Questions to which possible answers should be given are:

- How different is the current period called digital capitalism from the early periods of capitalism?

- How can the relationship between coal production and space technologies be expressed in the context of the exploitation of nature?

- Have technological advancements been effective in preventing mining disasters?

In today's capitalist society, capital accumulation is organised based on living labour despite having gone through many qualitative changes. The capitalist historical formation process has shown that surplus value production needs living labour. Technological developments did not abolish class-based society, nor did they change the capital accumulation process based on the exploitation of living labour. When the machine gradually takes over an industry, wrote Marx, "it creates a chronic misery between the workers who compete with it" (Marx 1867, 557). Indeed, that is the reason why $19^{\text {th }}$ century workers intended to smash the machines that threatened to take away their work, their food and their trade. Machine breaking was an important part of working class hatred in the early ages of mechanisation. 
This process quickly evolved into the obsessive screw-tightening tragedy of the workers in Chaplin's "Modern Times" (Chaplin 1936), as the worker became an extension of the machine. Today, technology controls labour while producing mechanisms that help establishing a tight connection between networks of exploitation. Capital is apparent not in the use-value of commodities, but in their production for profit (Ghosh 2012). The manufacturing process converts productive capital into commodity capital.

The exploitation of nature results in the commodification of natural resources. Human beings have developed tools to influence nature in order to dominate nature and to turn passive resources into commodities (Engels 1925, 462-463). When the efficiency of machines and human labour are compared, it is seen that people's employment areas are shrinking. As a result of the acceleration of technological progress, the development of the service sector has also accelerated, and the employment of unskilled labour has become increasingly difficult. Just like the industrial sector, the service sector has started using machines instead of employing unskilled and semi-skilled labour. The service sector and the industry sector, which needed more skilled labour, supported education and science, relatively increasing the level of education. Technological developments, which are an actor that narrows the employment areas of unskilled and semi-skilled labour, lead to cheaper prices and an increase in production, service quality, and efficiency.

When considered as a factor that led to industrialisation, it is seen that technology has an important place in the evolution of division of labour and specialisation. For example, the increased demand for a female workforce, for which there was less demand than a male workforce before industrialisation, has been due to the easing of labour-intensive working conditions and technological developments. Despite all these developments, we have not yet fully transitioned into a whole new era. Various modes of production and modes of the productive forces co-exist within the contemporary capitalist formation of society (Fuchs 2014, 170). The widespread use of technology has led to an increase in energy consumption. Therefore, the extraction of minerals used in energy production is still important. Although 175 years have passed since Engels wrote about the reality of the working class in England, global capitalism continues to thrive on the extraction of resources from nature.

Although alternative energy resources that can replace coal have been developed in the world since the 1980s and the dissolution of ESCS (European Coal and Steel Community) in Europe has led to significant developments in the global North, coal production retains its importance for developed and developing countries. Currently, $27 \%$ of the world's total energy production is produced from coal sources (Enerdata 2019):

In nine G20 countries, the absolute energy supply from coal increased between 2012 and 2017, mostly mirroring rising economic development in these countries and an overall increase in energy consumption: Indonesia $(+61 \%)$, India $(+26 \%)$, Turkey $(+28 \%)$, Brazil $(+8 \%)$, Mexico $(+7 \%)$, South Korea $(+6 \%)$, Japan $(+6 \%)$, Argentina $(+3 \%)$ and Russia (+ $3 \%$ ) (Climate Transparency 2019).

This study claims that today, coal production maintains its historical importance from the beginning of industrialization. The study examines social classes within the framework of class war and class experience. As someone who spent his childhood years in a mining town, had many relatives working in coal mines, and studied miners during 
his graduate and doctorate studies, my observations, experiences and personal views are reflected in this work.

\section{Microchips and Coal Production: Exploitation of Nature from the Underground to Space}

According to Engels, all living beings except human beings are passive rather than active in the formation of history (Engels 1925, 460). People make their own history. And with the modification of nature by history (Marx and Engels 1845/1846, 330), humans began their historical activity (Engels 1925, 330). The use of underground mines has an important place in the construction of above-mentioned history. Humans both belong to nature and are historical social beings.

The rational and free individual makes nature the object of their creative activity through their labour. This phenomenon, understood as the objectification of nature by reason, reflects the emergence of property in social terms. It indicates the closing of the distance between the subject and the object in philosophical terms. The epistemological contrast that modern philosophy establishes between subject and object turns into an ontological unity in the social relations of production. While Hegel demonstrated that this transformation is historical, Marx shows that this historical transformation is necessary but not at all human. Therefore, it transforms the subject-object association into a conditional one (Marcuse 2013a, 154). And thus it is not Hegel's theory that transforms the negatively characterised dialectic into a tool of affirmation. Marx's theory is a critique, in the context of all its concepts being an accusation of the whole of the existing order (Marcuse 2013a, 258).

In addition to the production of essential nutrients for life, the energy needed especially in the production of production tools is obtained from natural resources. In the process ranging from cooking and eating food to steam engines and launching rockets into space, all production tools are produced using energy from underground sources.

The link between mining and digital capitalism is evident in Christian Fuchs's (2014) study Digital Labour and Karl Marx. While defining the scope of digital labour, Fuchs $(2014,4)$, defines both the "slave" labour that extracts the materials used in mobile phones or computers from the mines, and the software developers in Silicon Valley or social media users as digital labour. Such workers are all "part of the collective labour force required for the existence, use and application of digital media" (Fuchs 2014, 4) that is organised in the form of an international division of digital labour (Fuchs 2014).

Although this holistic relationship is valid for every period of history, it is a fact that it accelerated with industrialisation. The relationship between the production and consumption of commodities is global and this process has accelerated with the free movement of capital. The rapid development of the western world in science and industry (Daggett 2019, 29), the central role of coal in industrialisation (Mumford 2010, 159) and the steam engines used in production have led to an acceleration in commodity production and the emergence of more workers (Hobsbawm 1999).

Although it is not possible to claim the existence of a uniform proletariat in terms of class culture and consciousness that has influenced the working class all over the world, one can speak of a similar work culture, common all over the world, where the structural conditions of working in coal mines are effective. Underground coal mine work is a sector where labour-intensive labour is especially prominent with very low mechanisation compared to other sectors. Regardless of class culture, a coal miner working in South Africa, China or Turkey is producing coal using similar technological tools. The current reality is quite similar to the working conditions of the miners de- 
scribed by Engels (1845), Orwell (2001) or Zola (2004). Despite using modern production tools, coal mining is much closer to the ancient production style of human struggle against nature due to the working conditions. Today, underground coal mining is in many ways as Engels $(1845,536-537)$ described:

All this deals only with the average of the English coal-mines. But there are many in which the state of things is much worse, those, namely, in which thin seams of coal are worked. The coal would be too expensive if a part of the adjacent sand and clay were removed; so the mine owners permit only the seams to be worked; whereby the passages which elsewhere are four or five feet high and more are here kept so low that to stand upright in them is not to be thought of. The working-man lies on his side and loosens the coal with his pick; resting upon his elbow as a pivot, whence follow inflammations of the joint, and in cases where he is forced to kneel, of the knee also.

Technological progress has not changed the form of exploitation. In May 2014, on the same day when 301 coal miners lost their lives in Turkey due to a mine disaster that took place in a mining town, a biotechnology firm called Deep Knowledge Ventures announced in Hong Kong that they had assigned an artificial intelligence to the board of trustees (Dyer-Witheford 2015). The appointment of an Al boss and the murder of miners taking place on the same day has made class exploitation much more obvious. In addition, despite the six years that have passed since the Soma mining disaster, most of the families of the miners who lost their lives and most of the injured miners have not received the compensation they are legally entitled to, and have organised various protests (a press release in front of the workplace, a march, a sit-in protest, a petition) in 2020 for their compensation.

With the increasing prevalence of renewable energy sources and technological devices that consume much less energy, "old style" energy production such as coal production was expected to come to an end. However, with the rapid development of industrialisation, hard coal, which is a high energy source, maintains its strategic importance today. According to data gathered in $2019,30 \%$ of the energy produced by G20 countries is produced using coal (Climate Transparency 2019, 3).

In an article published in Forbes Magazine in 1999, the following statement was used to emphasize the relationship between coal use and computer technologies: "Dig more coal, the PCs are coming" (Forbes 1999).

Although cognitive capitalism's mode of production is fundamentally based on the collective intellectual labour of people who come together and cooperate in digital networks (Moulier-Boutang 2011, 57) energy production is needed to ensure the conditions necessary for the reproduction of labour. This dialectical relationship may be possible as long as nature is reproduced. This contradiction between capital accumulation and the extraction of resources from nature results in both a crisis of nature and one of capital accumulation.

In the last quarter of the $20^{\text {th }}$ century, it became possible to send people to the planet Mars and establish colonies there. And moreover, a private company having the capital stock (SpaceX) to do this means moving the limits of capital accumulation beyond the world. While allowing access to new natural resources in case the natural resources on Earth are exhausted, it carries capitalism's idea of capital accumulation beyond the planet. 


\section{Miners Not Abiding by the "Rules" vs. "Saviour" Technologies}

Large companies have a cross-border scale organised around multifunctional digital networks. The financial sector invested a remarkable amount of money in information technologies in order to monitor digital network services and quickly changing prices, etc. while also ensuring investment security (Schiller 2011, 925). These investments have increased significantly, especially after 1970. Controlling labour (Baruh 2007; Andrejevic 2007; Cohen 2008) the mechanisation of production and work discipline have been going through a digital siege (Toscano 2007; Vercellone 2007). After all, "capital has an inherent drive and a constant tendency to raise the productivity of labour in order to cheapen commodities and the worker himself through the cheapening of commodities" (Marx 1867, 436). Regulations regarding worker health and safety in underground mining are made with parameters such as groundwater conditions, hazardous gases, fires, explosions, dents, and ventilation in mind (Bennett and Passmore 1984).

In today's mining industry, underground control is achieved by using various technological tools. Underground movements can be monitored by microchips attached to workers' helmets or lamps. Entries and exits to mines are controlled by digital tallymen with iris scanners. These regulations, made to discipline workers who have more control over their labour than their bosses in underground working conditions (Lyon 1994, 55), are imposed with the discourse of "protecting" workers against the "unexpected" risks of underground working conditions.

Fatal accidents still cannot be prevented in today's mining, where worker health and safety practices are digitalized. Considering the amount of informal work in the mining sector, it can be said that death statistics contain serious deficiencies. The existence of many seasonal coal mines operating informally in Zonguldak, Turkey, an area full of coal reserves, is common knowledge. Accidents or deaths of employees in such enterprises are not reflected in official statistics.

The root cause of the catastrophes in coal mines is the selfishness of the bourgeoisie (Engels 1845, 537). Looking at the top 20 of the deadliest mining disasters in the world in the last 50 years, it is seen that 13 of them took place between 2000-2014 (Burton, Ivanova, and Lewis 2019). Again, among the mining disasters that took place in those years, 30 miners lost their lives in Afghanistan in 2019; 301 in Turkey in 2014 , 57 in the Central African Republic, 83 in China-Tibet, and 66 in China in 2013 (Garside 2020). In India, from June 2016 to June 2019, a total of 417 miners died in fatal mine accidents, and 238 of those killed were coal miners (Industrial Global Union 2019). Considering the current state of technology, there is no obstacle to the prevention of fatal mining disasters. However, today just like at the time of Engels investments that would prevent accidents are being neglected in order to generate more profit:

A proper ventilation of the mines by means of fresh air-shafts could almost entirely remove the injurious effects of both these gases. But for this purpose the bourgeoisie has no money to spare, preferring to command the working-men to use the Davy lamp, which is wholly useless because of its dull light, and is, therefore, usually replaced by a candle. If an explosion occurs, the recklessness of the miner is blamed, though the bourgeois might have made the explosion well-nigh impossible by supplying good ventilation. Further, every few days the roof of a working falls in, and buries or mangles the workers employed in it. It is the interest of the bourgeois to have the seams worked out as completely as possible, and hence the accidents of this sort. Then, too, the ropes by which the men descend into the mines are often rotten, and break, so that the unfortunates fall, and are crushed (Engels 1845, 537-538). 
If what class the miracle belongs to and the conditions of that class are not taken into consideration; cheering for technical advancements is futile (Bloch 1995, 241). The domination of technological progress in working life is also a form of class domination. The technological progress in which production has increased but worker safety is ignored makes itself apparent in the mining sector. Accidents associated with machinery in the workplace are portrayed as the fault of the worker or the machine. Technology, on the other hand, is always affirmed. For example, the safe rescue of workers stranded underground in a mine in Chile on August 5, 2010, after 69 days, was possible thanks to technology, but no one seems to be responsible for not taking measures before the accident happened. Technology being portrayed as a saviour has been used to cover up imprudence.

While the working life of today's mine worker is controlled by technology, the technological reality is that technological equipment that will prevent workers from dying or having serious accidents is activated only when production is disrupted. However, the reality is distorted to make it seem that employees who do not obey the rules are responsible for the bad things that happen to them, and that technological control is to protect their health and watch over them.

\section{New Social Movements and the Miners We Know}

Machines or technological elements, which are the visible form of digitalization, are not subjects in themselves. They do not say "we do what living labour does at lower costs" or "we are working to end global exploitation" with their free will. Information and communication technologies (ICT) are tools used to increase the alienation of living labour. The limit of technical evolution for the bourgeois society in which we live is a form of capitalism that has developed all the productive forces it can contain, but has somehow not been destroyed (Marcuse 2013b). To understand society, it is necessary to analyse collective organizations that machines are only a part of (Deleuze 1992,6).

One of the best works that reflect a bottom-up history or class struggle perspective on historical analysis is Eric J. Hobsbawm's (1952) work on machine breakers. In the Communist Manifesto, Marx and Engels $(1848,492)$ emphasise the class conflict aspect of machine-breaking and the aspect of struggle that spans from individual workers to the entire factory and from there to a particular line of business. Engels $(1845,503)$ emphasises that the first resistance by workers as a class against the bourgeoisie in the early industrialisation period was machine breaking:

As a class, they first manifested opposition to the bourgeoisie when they resisted the introduction of machinery at the very beginning of the industrial period. The first inventors, Arkwright and others, were persecuted in this way and their machines destroyed. Later, there took place a number of revolts against machinery, in which the occurrences were almost precisely the same as those of the printers' disturbances in Bohemia in 1844; factories were demolished and machinery destroyed.

Hobsbawm $(1952,63)$ took these evaluations one step further, emphasising that mechanisation increased most during periods when unemployment increased and employees' dignity decreased, and that there were machine-breaking movements against these developments. The workers were carrying out these actions not against mechanisation itself, but against the threats brought by mechanisation. Although Hobsbawm partially admits that the act of machine breaking is not a dominant method of struggle in the exploitation of labour due to industrialisation, he proves that machine breaking 
is effective by giving some examples in favour of the working class from the history of the British working class.

In the age of digital capitalism, discussions of resistance can be grouped under two main headings. The first of these is that the resistance will start from a distinction based on identity differences and the other is that the struggle of the working class will be effective.

History has shown, in a way that contradicts Althusser, that class conflict does not spontaneously arise from a structural determination. In the context of resistance, workers' level of alienation is and what they perceive as exploitation is important.

According to Ollman (1987), class consciousness is the agency of the masses of workers who have class consciousness, rather than an entire body of awareness consisting of certain feelings and thoughts. Class consciousness, to be more precise, is constituted by the interests and demands of individual class members towards their class, their sense of solidarity and opposition to other classes, and striving for a more egalitarian society through the assimilation of the dynamics of capitalist society.

The miners' strikes that took place in various parts of the world between 1970 and 1990, when neoliberal policies began to be implemented, are quite remarkable. The miners' strike of 1977/78, which started in six workplaces in 1977 and lasted about 109 days (Ackermann 1979) in the USA, emerged as the self-defence of the working class against the general attack of the capitalist class (Green and Buhle 1983, 322). In 1977, 35,000 miners took part in a strike in Romania's Jiu Valley, protesting against overtime hours, low wages and the rise in the age of retirement (Kideckel 2004, 45). Although in a different context from the above-mentioned strikes, during the dissolution of the USSR in the same period, there were major miners' strikes in Kuzbass in 1989, and Donbas in 1990 and 1991 (Marples 2013, 31). The Zonguldak strike, started by 48,000 coal miners in Zonguldak, Turkey in November 1990, reached 100,000 participants in January 1991 with the participation of the miners and their families. This strike was one of the biggest acts of resistance against privatisation policies in Turkish working-class history. As a result of this strike, mines were not privatised, but many workers were retired.

The most well-known of these strikes was the British miners' strike in 1984-85 that affected the whole of England. After the oil price shock in 1973, rising inflation and a sharp decline in real wages led to conflict among workers, and although there was a decline in strikes until 1980, they were followed by significant increases in the number of strikes after 1980 (Lyddon 2007, 339). The working class, in particular the miners, were fighting against Margaret Thatcher for their right to work (Leeworthy 2012, 837). The general purpose of these strikes in Britain, including the miners' strikes, was to oppose the state's privatisation policies, their oppressive policies on the unions, and the general policies that were trying to take away the working class' power to resist (Steber 2018, 69).

In the 2000s, compared to the mass strikes of the 1990s, there were generally smaller-scale, workplace-based strikes. Apart from Asturian miners' strike in 2012 (Spain), the South Africa Marikana miners' strike, and the 2019 Harlan County coal miners' protest in the USA, these strikes consisted mostly of small-scale strikes, actions and protests on a local basis in accordance with the spirit of this period.

It is clear that classes are not structures that develop on a regular and consistent line. The class participation of the miners in question continues in the historical process not by proactive but by occasionally interrupted trends, mostly withdrawn from organized class movement and stuck within the framework of daily forms of resistance. 


\section{Conclusion}

Currently, coal production is as important in the processes of capital accumulation as it was in the most active times of the industrial revolution. The primary effect of the age of digital capitalism is the rapid circulation of capital. Thus, the capital acquired as a result of the coal produced is turned into an investment by going back into circulation, even in third world countries. Capitalist processes of capital accumulation organised around living labour grow through the commodification of nature.

Coal mining comprises a basis where we can read both the continuity and the discontinuities in the capitalist mode of production. The fact that coal is still being produced today reveals a continuity in terms of capitalist production strategies and the need for raw materials. At the same time, despite the advanced technological infrastructure, it remains a sector where mining disasters still occur, and where precarious work can be seen in the clearest way due to its working conditions.

Today, we see that the energy obtained from coal maintains its importance in meeting the increasing energy need both in the use and production of technology. It is likely that the energy produced from coal will be used in the process of commodifying "precious metals" found on extra-terrestrial planets that are still not commodified. Coal mining, which stands at the centre of the node between traditional and digital capitalism, is at the centre of capital accumulation processes from earth mining to space mining.

The first steps of space mining have been taken by means of high-tech devices sent to the Moon and Mars and used by people on earth. The fact that the most important steps are taken not through states but through capitalist private enterprises shows that the process of transforming extra-terrestrial nature into a commodity has entered the processes of capitalist capital accumulation.

In the age of digital capitalism, it is seen that technological progress is used for the control of working life rather than worker health safety. The most important indicator of this is that the highest fatal mining disasters in the mining sector took place in the 2000s despite the advanced technological infrastructure. It is clear that in today's coal mining, technology dedicated to control continues to work for capitalists rather than employees.

As a component of the social relations of production, nature lies at the heart of class and power struggles. Despite the capital accumulation processes obtained from the exploitation of nature, which can be associated with every stage of production, coal mine worker movements have an important place in the struggle. Although the coal miners who vigorously resisted against neoliberal policies in the 1990s could not overthrow neoliberal policies, the struggle continues.

\section{References}

Ackermann, John A. 1979. The Impact of the Coal Strike of 1977-1978. ILR Review 32 (2): 175-188.

Andrejevic, Mark. 2007. Surveillance in the Digital Enclosure. The Communication Review 10 (4): 295-317.

Baruh, Lemi. 2007. Read at Your Own Risk: Shrinkage of Privacy and Interactive Media. New Media \& Society 9 (2): 187-211.

Bennett, James D., and David Lynn Passmore. 1984. Correlates of coal mine accidents and injuries: A literature review. Accident Analysis \& Prevention 16 (1): 37-45. https://doi.org/10.1016/0001-4575(84)90004-6

Bloch, Ernst. 1995. The Principle of Hope. Translated by N. Plaice, S. Plaice and P. Knight. Vol. Volume 2. Cambridge, MA: The MIT Press. 
Burton, Melanie, Polina Ivanova, and Barbara Lewis. 2019. Factbox: Vale tailings dam collapse adds to long list of mining disasters. Reuters. https://reut.rs/2MEwi5v

Chaplin, Charlie. 1936. Modern Times. United States.

Climate Transparency. 2019. Managing the Coal Phase-Out - A Comparison of Actions in G20 Countries. Berlin, Germany: Humboldt-Viadrina Governance Platform.

Cohen, Nicole S. 2008. The Valorization of Surveillance: Towards a Political Economy of Facebook. Democratic Communique 22 (1): 5-22.

Daggett, Cara New. 2019. The Birth of Energy: Fossil Fuels, Thermodynamics, and the Politics of Work. Durham, NC: Duke University Press.

Deleuze, Gilles. 1992. Postscript on the Societies of Control. October 59: 3-7.

Dyer-Witheford, Nick. 2015. Cyber-Proletariat: Global Labour in the Digital Vortex. London: Pluto Press.

Enerdata. 2019. Total Energy Production. https://yearbook.enerdata.net/

Engels, Frederick. 1925. Dialectics of Nature. In Marx \& Engels Collected Works (MECW) Volume 25, 311-588. London: Lawrence \& Wishart.

Engels, Friedrich. 1845. The Condition of the Working Class in England. In Marx \& Engels Collected Works (MECW) Volume 4, 295-596. London: Lawrence \& Wishart.

Forbes. 1999. Dig More Coal - the PCs are coming. Forbes, May 30.

Fuchs, Christian. 2014. Digital Labour and Karl Marx. New York: Routledge.

Garside, M. 2020. Number of casualties in mining accidents worldwide 2005-2019. Statista.

Ghosh, Jayati. 2012. Capital. In The Elgar Companion to Marxist Economics, edited by Alfredo Saad-Filho and Marco Boffo, 28-33. Cheltenham: Edward Elgar Publishing.

Green, James, and Paul Buhle. 1983. Holding the Line: Miners' Militancy and the Strike of 1978. In Workers' Struggles, Past and Present, edited by James Green, 321-343. Philadelphia: Temple University Press.

Hobsbawm, Eric J. 1999. Industry and Empire: From 1750 to the Present Day. New York: The New Press.

Hobsbawm, Eric J. 1952. The Machine Breakers. Past \& Present 1: 57-70.

Industrial Global Union. 2019. Four coal miners dead and nine injured in a coal India accident. http://www.industriall-union.org/four-coal-miners-dead-and-nine-injured-in-a-coal-india-accident

Kideckel, David. 2004. Miners and Wives in Romania's Jiu Valley: Perspectives on Postsocialist Class, Gender, and Social Change. Identities 11 (1): 39-63.

Leeworthy, Daryl. 2012. The Secret Life of Us: 1984, the Miners' Strike and the Place of Biography in Writing History "From Below". European Review of History: Revue européenne d'histoire 19 (5): 825-846.

Lyddon, Dave. 2007. From Strike Wave to Strike Drought: The United Kingdom, 1968-2005. In Strikes Around the World, 1968-2005: Case-Studies of 15 Countries, edited by Sjaak van der Velden, Heiner Dribbusch, Dave Lyddon and Kurt Vandaele, 339-365. Amsterdam: Aksant.

Lyon, David. 1994. The Electronic Eye: The Rise of Surveillance Society. Minneapolis: University of Minnesota Press.

Marcuse, Herbert. 2013a. Reason and Revolution. New York: Routledge.

Marcuse, Herbert. 2013b. One-Dimensional Man: Studies in the Ideology of Advanced Industrial Society. New York: Routledge.

Marples, David R. 2013. The Collapse of the Soviet Union 1985-1991. New York: Routledge.

Marx, Karl. 1867. Capital. Volume I. London: Penguin.

Marx, Karl, and Friedrich Engels. 1845/1846. The German Ideology. Critique of Modern German Philosophy According to Its Representatives Feuerbach, B. Bauer and Stirner, and of German Socialism According to Its Various Prophets. In Marx \& Engels Collected Works (MECW) Volume 5, 19-539. London: Lawrence \& Wishart.

Marx, Karl, and Friedrich Engels. 1848. The Manifesto of the Communist Party. In Marx \& Engels Collected Works (MECW) Volume 6, 477-519. London: Lawrence \& Wishart. 
Moulier-Boutang, Yann. 2011. Cognitive Capitalism. Translated by Ed Emery. Cambridge: Polity.

Mumford, Lewis. 2010. Technics and Civilization. Chicago: University of Chicago Press.

Ollman, Bertell. 1987. How to Study Class Consciousness, And Why We Should. Insurgent Sociologist 14 (1): 57-96.

Orwell, George. 2001. The Road to Wigan Pier. London: Penguin.

Schiller, Dan. 2011. Power Under Pressure: Digital Capitalism In Crisis. International Journal of Communication 5: 924-941.

SpaceX. n.d. Starship. Accessed September 13. https://www.spacex.com/vehicles/starship/

Steber, Martina. 2018. Fundamentals at Stake: The Conservatives, Industrial Relations and the Rhetorical Framing of the Miners' Strike in 1984/1985. Contemporary British History 32 (1): $60-77$.

Toscano, Alberto. 2007. From Pin Factories to Gold Farmers: Editorial Introduction to a Research Stream on Cognitive Capitalism, Immaterial Labour, and the General Intellect. Historical Materialism: Research in Critical Marxist Theory 15 (1): 3-11.

Vercellone, Carlo. 2007. From Formal Subsumption to General Intellect: Elements for a Marxist Reading of the Thesis of Cognitive Capitalism. Historical Materialism: Research in Critical Marxist Theory 15 (1): 13-36.

Zola, Émile. 2004. Germinal. Translated by Roger Pearson. London: Penguin.

\section{About the Author}

Akın Bakioğlu

Akın Bakioğlu received his $\mathrm{PhD}$ degree in Sociology from Ankara University in Turkey in 2019. His PhD work was entitled as "Working Class Formation in Zonguldak Coal Basin". He holds an MA degree in Sociology, from Süleyman Demirel University in Turkey (2011). His MA work was titled "Sociological quality of mine workers: working life and off-job life; an application in the Institution of Coal Mine in Turkey". His research interests are mine workers, industrial sociology, migration studies and labour economics, and industrial relations. 


\title{
Revisiting Friedrich Engels's Dialectics of Nature in an Age of Digital Idealism
}

\author{
Christopher Leslie
}

South China University of Technology, Guangzhou, and Zhejiang Hexin Group, Yunhe County, People's Republic of China, chrisleslienyc@hotmail.com

\begin{abstract}
The idealism that Fredrich Engels seeks to defeat in Dialectics of Nature today pervades online discourse and pedagogies of science, technology, engineering, and mathematics (STEM). The deterministic view that STEM is dedicated to unleashing the inherent power in objects for the service of privileged societies fails to understand the basic principles that Engels proposed. Engels exposes his contemporaries' flawed understanding of science and technology and provides interdisciplinary examples that exemplify a different way of thinking. Outside of China, Engels's ideas have been used suggest that social considerations cannot be a part of science because they limit the free exchange of ideas. Within China, particularly after the establishment of the People's Republic in 1949, these ideas have been the basis of new thinking about the relationships among developers, the government, and the people. Moreover, readers of Dialectics of Nature who are familiar with the basic tenets of Science and Technology Studies (STS), such as social constructivism and actor-network theory, will not be so impressed with the idea that social theory has no place in understanding science and engineering. This analysis suggests avenues of cooperation for international science studies. In addition, it provides a starting point for pedagogies to promote the development for science and technology that reduces inequality and supports the notion that the liberal arts have an important place in the study of science and engineering, an insight known as STEAM.
\end{abstract}

Keywords: Dialectics of Nature, Friedrich Engels, Science and Technology Studies, social constructivism, STEAM, sustainable development

\section{Introduction}

Friedrich Engels's unfinished Dialectics of Nature, which was written mainly from 1872 to 1882 , offers an interdisciplinary approach to communicating about science. The way we talk about scientific discovery, to Engels, seems as if power is being released in one direction: the force of evolution, the application of electricity. We assume the natural world is unchanging. When teaching engineering students about the history of technology in Brooklyn, N.Y., one of my favourite conversations was with students who did not believe that technology had a history. They had been carefully prepared by their families and secondary schools for success in science, technology, engineering, and mathematics (STEM), so their antipathy toward taking a liberal arts or social science look at engineering seems indicative of a larger ideological challenge.

One semester, I was teaching two courses that incorporate the liberal arts, such as literary study or history, with the study of STEM, an idea that has now been called STEAM by Yakman (2008). A student who attended the first meeting of my history and philosophy of the Internet class surprised me by adding my science and literature class the second week. I felt flattered, thinking that I had impressed him so much that he decided to take two humanities electives with me. The student quickly disabused me, informing me that engineers do the best they can with the tools they have available, so there is no such thing as interaction between the social world and innovation. 
Had the student chosen to spend a few more weeks in the class, I would have been happy to introduce him to the robust scholarship about social constructivism in Science and Technology Studies (STS) that shows how engineers are always imagining users when they are working, and that the social world is always shaping which technological choices seem to be right through law, ideology, economics, history, and even the physical environment. To me, it seems obvious that people who are striving to be innovators would benefit from understanding how judgements are made about new developments, either fitting them in with current thinking or by finding allies when they hope to be disruptive. Indeed, the modern field of STS owes much to a group of Scandinavian scholars who, in the 1980s, hoped to understand how larger economic, historical, and political circumstances made it easier for an oligarchy of companies from an elite group of nations seemed so often succeed. These early practitioners had the goal of understanding why smaller companies cannot set industry standards that promote their own interests.

We live at a time with pervasive harmful ideologies about science and technology. In the news and in government rhetoric, audiences witness a deterministic attitude that technology is independent of society, perhaps developing so fast that culture and the law cannot keep up with it. Many students, faculty, and professionals in STEM believe that it is their duty to provide the most efficient and cost-effective innovation to market, whereas considering social issues (not only supporting equity and eliminating poverty, but also eliminating unearned privilege in STEM careers) are tasks somehow exterior to scientific and technical research. One group of students and colleagues always seems to deride any attempt to connect words like "philosophy" with science or engineering, and there is always a gendered undertone to the criticism: historical or philosophical analysis is about feelings and opinions, which have nothing to do with science.

To be fair, many STEM students take an interest in these topics, so much so that we founded an interdisciplinary undergraduate major in STS in 2005. For some - particularly members of demographic groups that had been traditionally excluded from engineering (based on gender identity, ethnicity, or national origin) - the opportunity to study why science and technology seem to reinforce existing social assumptions and fail to benefit all strata of society equally. In this context, Engels's ideas are a strong reminder that the disconnect between science, technology, and society was resisted from the first days of the industrial revolution. His notes and ruminations in the unfinished text offer a starting point for further work on equitable and sustainable development that can come from sound science and technology policy.

\section{Dialectics and the Second Industrial Revolution}

One might rightly wonder about the motivation for Engels preparing a book about the dialectics of nature (the title in German is Dialektik der Natur, the noun Dialektik without an article indicating a plural). The examples in his book are more often about what today we would consider science and the secondary literature is interested in Engels's supposed scientific method. Would not Dialektik der Wissenschaft (Dialectics of Science) or something similar be more appropriate? In fact, several of Engels's word have something to say about the history of science and how to best understand his ideas.

Using the word scientist to describe a person is relatively new, the word originating in a book review by William Whewell in the mid-nineteenth century, contemporary with Marx and Engels. The word science is older, but it referred to the end process of studying: what someone has learned. What Engels calls "Die moderne Naturforschung" in the introduction is translated in MECW as "modern natural science," but Engels's phrase is more of a vexed locution than it might appear. Understanding his choice of 
"Naturforschung" (closer in meaning to investigation of nature) ${ }^{1}$ over something like "Wissenschaftsforschung" (science studies, or science of science) might be difficult to fathom, except that there are several contextual clues.

First, the conflict between natural philosophy and natural history illuminates the focus of this work. STS scholars point to the debates between Thomas Hobbes and Robert Boyle in the late seventeenth century. Although their disagreement is largely remembered for Hobbes's incorrect statement that there could be no vacuum, a foundational text in STS states that the controversy was more about the proper method to investigate the natural world (Shapin and Schaffer 2011). Hobbes, uneasy about dissent in the wake of the English civil war, expected that science should proceed deductively from known principles and explain phenomena so clearly that no one could disagree. Like a geometric proof, someone could misunderstand, but no one could disagree. The name for this endeavour was natural philosophy. Boyle, for his part, preferred to work from what he saw, the small observations building up to a conclusion inductively. Boyle demanded that science be based on what is "sensible," while Hobbes said that the human senses are easily fooled; Hobbes's distaste for Boyle's work - the impression that Boyle was simply recording the incidents before him - led to what he thought of as an epithet; nonetheless, natural history eventually came to be used by the followers of Boyle. This is seen in the institutions that took the name, such as the 1793 Muséum national d'histoire naturelle in France.

William Whewell, one of Charles Darwin's professors at Cambridge, helped formalise the inductive method of the natural historians. Darwin's work is a triumph of the inductive method, building from minute observations he started to collect while on board the Beagle and eventually from empirical investigation to support the supposition that species evolved from one into the other, an idea first credibly proposed by a researcher at Paris's natural history museum, Jean Baptiste Lamarck. In spite of Darwin's ultimate conclusion - that chance and history formed species, with unexpected benefits from random differences giving a group a greater ability to reproduce - his teacher and his contemporaries were not convinced that nature was changing in the way Darwin proposed; they preferred to think that evolution was progress toward perfection. Whewell (1840) starts off his text with the first principle: "Man is the Interpreter of Nature, Science the right interpretation" (xvii). Whewell's interest in the inductive method was to gain access to the one, true nature. For instance, Whewell's aphorism number 56 concerning science reads: "In contemplating the series of Causes which are themselves the effects of other causes, we are necessarily led to assume a Supreme Cause in the Order of Causation, as we assume a First Cause in Order of Succession" (xlvii). Regardless of the conflict between natural philosophers and natural historians, they seem unified in their presumption in a singular, unified world.

This contradiction is noted by Engels when he provides a short history of science. The English-speaking world might mark the age of science with the Boyle-Hobbes debate, but for Engels, modern science was continuation of the Protestant Reformation. In 1517, when Martin Luther published his objections to the Church, Engels sees the beginning of "Naturforschung", the time when free inquiry supplanted theology. Notwithstanding these conflicts, Engels saw the process unfinished. In particular, the growing investigation was limited by an unexpected continuity: "Science was still deeply enmeshed in theology" (Engels 1925, 322). Engels suggests the revolution was

${ }^{1}$ An important eighteenth-century German scientific journal was Der Naturforscher; this title might best be translated as "The Naturalist". 
unfinished because savants were still seeking the one, unchanging universe, as if it had been created by a deity.

This difference of understanding can be seen in later considerations of the dialectic as described by Emery (1935). With dialectics, objects are always in the midst of forces; "no matter exists without motion" (18). An idealism that was identified by Newton and fostered during the Enlightenment suggests that matter and movement are two separate things; objects are stable unless they are acted on. Every action has a cause and the same action always obtains the same result; there is no place for chance (31). Extrapolating this view of the natural world, it can be wrongly assumed that human beings are, in their natural state, independent of each other. A religious reverence for absolute space and absolute time hinders an understanding of the interrelationships in nature. Engels (1925) writes that the underlying belief was that of "the absolute immutability of nature" (321). He continues:

In contrast to the history of mankind, which develops in time, there was ascribed to the history of nature only an unfolding in space. All change, all development in nature, was denied. Natural science, so revolutionary at the outset, suddenly found itself confronted by an out-and-out conservative nature in which even today everything was as it had been at the beginning and in which - to the end of the world or for all eternity - everything would remain as it had been since the beginning (322).

A triumph of this world in flux was when Darwin in his 1859 Origin of Species proposed that evolution was based on the competition for scarce resources, some species finding an advantage due to unexpected morphology. At a time when techniques for production had made it possible "so that a child now produces more than a hundred adults previously did," Engels $(1925,331)$ writes that this understanding of nature was no benefit because of the misery of so many human beings. Making a connection between material history and the history of science, Engels $(1925,331)$ writes that Darwin wrote a "bitter satire" when he showed that the so-called free market celebrated by economists "as the highest historical achievement" but is really just the normal conditions of the animal kingdom. He continues:

Only conscious organisation of social production, in which production and distribution are carried on in a planned way, can lift mankind above the rest of the animal world as regards the social aspect, in the same way that production in general has done this for men in their aspect as species. Historical evolution makes such an organisation daily more indispensable [unumgänglicher, which could also be 'inevitable'], but also with every day more possible. From it will date a new epoch of history, in which mankind itself, and with mankind all branches of its activity, and especially natural science [Naturwissenschaft ${ }^{2}$, will experience an advance that will put everything preceding it in the deepest shade (Engels 1925, 331).

Clearly, Engels takes inspiration from the idea that the incomplete realisation of the Reformation on science, which was now showing that the world was changeable, could now serve as a rationale for political change. Key to this different mode of thought is the reciprocal actions of humans and their environment. Keeping in tune with the idea

2 The translators use "natural science" for both Naturwissenschaft and Naturforschung. 
that humans create their own society, Engels points out that the separation of the natural world and the human history is a myth:

Natural science [Naturwissenschaft], like philosophy, has hitherto entirely neglected the influence of men's activity on their thought; both know only nature on the one hand and thought on the other. But it is precisely the alteration of nature by men, not solely nature as such, which is the most essential and immediate basis of human thought, and it is in the measure that man has learned to change nature that his intelligence has increased. The naturalistic conception of history, $[\ldots]$ is therefore one-sided and forgets that man also reacts on nature, changing it and creating new conditions of existence for himself. There is devilishly little left of 'nature' as it was in Germany at the time when the Germanic peoples immigrated into it. The earth's surface, climate, vegetation, fauna, and the human beings themselves have infinitely changed, and all this owing to human activity (Engels 1925, 511; emphasis in original).

Engels rejects a teleological idea of evolution, one that was supported by natural philosophy, but does not often directly address capitalism in this text. Instead, he attacks the ideological foundations of capitalism that derive from the Enlightenment. After all, Newton's laws of motion and Adam Smith's analysis of capitalism are contemporaries. They both assume that the universe is unchanging but filled with the potential to unleash force in order to accomplish work. He seeks to expose this fallacy by showing that nature consists at its basic level as entities that are always divisible and that are always operating on each other. At a higher level, he seeks to embrace the continuing scientific revolution, rejecting a one-sided science that is only designed to exploit nature and forging the notion that human beings have different options. In this way, he seeks to build on the appeals to science and human rights espoused, but not necessarily achieved, by the natural historians.

\section{Dialectics During the Communication Revolution}

One should not underestimate the way in which interdisciplinary scientific metaphors were bandied about while Engels was writing. Spencer and other proponents lent authority to their public statements about racial hierarchy through analogy to the new science of thermodynamics. Conservation of energy, to Spencer, was the reason why eventually humanity would inevitably evolve into a homogenous, superior species. He presumed that at the lower levels of the evolutionary tree, a proliferation of types was possible because they were not too complicated and required less life energy. Moving up the ladder of complexity required more energy, meaning that nature could no longer support a proliferation of types. Thus, there are more types of mould then there are mammals. The higher the form of life, the less energy there was for diversity, and the inevitable result would be one form of humanities. The evidence for this, according to the social Darwinists, was the coming extinction of aboriginal people and the spread of the so-called "white race".

Engels did not directly address the connection between the second industrial revolution and what historians now call the scramble for Africa, the forty-year period when almost ninety percent of the continent was brought under colonial control (Chamberlain $2013,3)$. It is possible to see how the theory that technology is dependent on the exploitation of nature is implicated in the process of colonization. The raw material needed for the communication revolution in the latter part of the nineteenth century material such as tin, lead, rubber, gemstones, and precious metals - was most easily 
obtained through colonial power. The pseudoscience of racial evolution, suggesting that one superior race would the inevitable and best outcome of humanity and the rest of humanity was doomed to inevitable destruction, was a consequence of forcing Darwin's thinking into the teleological prejudices of the time. The objective and democratic ideals of Enlightenment science were tainted by an eschatological belief akin to religion, The uneven nature of technical development during and after the industrial revolution, as de Sousa Santos (2018) has pointed out, calls into question the dream of "science for all" that began in the Enlightenment. The self-congratulatory notion of natural philosophers in the eighteenth century that anyone could participate in science was coincident with the dream of universal human rights that would benefit all of humanity. However, this idealist dream did not imagine the consequences of combining science with capitalism. He writes:

capitalism would be inherently unable to relinquish the concept of the subhuman as an integral part of humanity, that is to say, the idea that there are some social groups whose existence cannot be ruled by the tension between regulation and emancipation (de Sousa Santos 2018, 276)

In Dialectics of Nature, Engels seeks to improve the ideals of the Reformation and promote the best aspects of the scientific revolution by means of a philosophy that would not require the subjugation of humans, but is faced with a communication problem similar to Darwin's. In spite of Darwin's assertion that chance and not superiority drove species to succeed, the popular understanding was that superior abilities derived from evolutionary forces. Presumptions about the calm organisation of humanity infused the popular understanding of the natural world in the nineteenth century. Both bees and birds fly, but no one would expect them to mate - the supposedly unique and unchanging characteristics of those species used hyperbolically to support laws against miscegenation and supporting race-based slavery.

No matter what Darwin tried to communicate, his ideas were forced into the existing paradigm of normal science to form social Darwinism, which was invested not just in a hierarchy of races but also the idea that the economic and legal systems intrinsic to the industrial revolution should dominate the world's systems. It was, after all, not Darwin but Herbert Spencer who coined the phrase "survival of the fittest". Human superiority due to using tools is the emblem of this ideology. The social Darwinist interpretation of evolution would suggest that evolution gave humanity a hand, which then allowed humans to exploit nature by the use of tools. The survival benefit from tools for social Darwinism thus a deterministic event, and one can suppose that the humans who use the best tools are the ones who are the fittest to walk the earth. Engels describes this interpretation as one that highlights the exploitation of a unidirectional force.

In the same way that Darwin's work undermines the way in which the findings of natural history were used to support public arguments to support slavery, ${ }^{3}$ Engels

${ }^{3}$ The subtext of Origin of Species is Darwin's belief that there was only one human species, a supposition that would undermine claims that some races were biologically distinct and better off being enslaved (Desmond and Moore 2011). Although he does not directly attack the institution of slavery, his work is full of examples that undermine the justification for slavery: how biological organisms are not members of pure species, that diversity provides species with a robust defence against adversity, and that chance less than superiority accounts for why some species are more successful in an environment. It is worth mentioning that Darwin's companion to Origin of Species, Descent of Man, was first published in 1871, which is 
shows how the communication of science was still in service of a priest-like power. For Engels, the scientific revolution should have stopped the priestly practice of an elite caste standing between humanity and a great eminent power, and yet paradoxically the natural scientists seemed to have taken the place of the priests. Despite the revolution, they still stood as an elite between power and the people.

Engels's description of the evolutionary power of the human hand illustrates how he expects the public to see dialectics in something as fundamental as the formation of humanity. In his discussion of the hand, Engels shows evolution to be a balance of contradictory forces and, at the same time, that dialectics were in fact an intrinsic principle of the universe. There was no release of force that gave humanity a hand and then created a superior species, Engels points out. Instead, there was a recursive process. The early form of the hand allowed mammals to manipulate their environment and later primitive tools. Being able to walk upright made the use of tools easier, the accident that increased cranial capacity made it possible to use tools smarter. Using better tools with better intelligence created success for the species, which then allowed for humans to take advantage of further biological modifications. The tool and humanity were thus bound in a reciprocal process of evolution. He then makes the connection to the industrial revolution:

Man alone has succeeded in impressing his stamp on nature, not only by shifting the plant and animal world from one place to another, but also by so altering the aspect and climate of his dwelling place, and even the plants and animals themselves, that the consequences of his activity can disappear only with the general extinction of the terrestrial globe. And he has accomplished this primarily and essentially by means of the hand. Even the steam engine, so far his most powerful tool for the transformation of nature, depends, because it is a tool, in the last resort on the hand. But step by step with the development of the hand went that of the brain; first of all consciousness of the conditions for separate practically useful actions, and later, among the more favoured peoples and arising from the preceding, insight into the natural laws governing them. And with the rapidly growing knowledge of the laws of nature the means for reacting on nature also grew; the hand alone would never have achieved the steam engine if the brain of man had not attained a correlative development with it, and parallel to it, and partly owing to it" (Engels 1925, 330).

Certainly, as in his example of the human hand, one cannot simplistically say that humans are superior because they use tools; humanity and human tools evolved together. Engels's more technical descriptions - like his discussion of the reciprocal action of electrons that opposes the popular notion of unleashing electric force - show how culture and ideology clouds insight and hinders innovation.

In addition to well-developed and thoughtful analyses like these are comments in the text about how the failure to consider the dialectical nature of technical development leads to unexpected impacts in the social world. For instance, Engels wonders whether the Arabic scientists who first discovered how to distil alcohol could have ever imagined how spirits would be one of the tools used to subjugate indigenous populations. An individual who believes in the objective and disinterested nature of scientific progress would say it was not any of the original scientists' fault that their discovery

during the time Engels was writing. Desmond and Moore propose that the implications of natural selection on humanity rejected so much of Darwin's contemporaries that he delayed extending his finding to humans for twelve years. 
was used this way. This is not the only and best way to consider scientific discovery, however. One can make the argument that it is precisely the responsibility for innovators to account for what can go wrong and to build up safeguards against misuse, always considering the impact on the social fabric.

Another example Engels mentions without much development is the steam engine, which certainly played a leading role in the Manifesto. On the one hand, Engels praises the development of the steam engine because it was one of the first truly international inventions. The fact that scientists and practitioners in so many different countries contributed to the abstract theory and practical development of the steam engine indicates the degree to which the world had become a global community at the turn of the eighteenth century. The way the steam engine was put into use for manufacturing, though, had a negative impact on the masses of workers. No one developing the steam engine seems to have thought about the misery and loss of autonomy that production methods would have brought about.

Although the use of steam power caused a crisis for the working class, what goes unstated by Engels is that the international nature of this crisis provided the international opportunity for a response to change the way that the technology was being used. Throughout this interplay of competing forces, Engels is consistent in his assertion that these various developments are not inevitable, but a peculiar result based on specific circumstances. He notes that animals have a history, in the sense they have path through evolution, but "this history, however, is made for them" and it "occurs without their knowledge or desire" (Engels 1925, 330). The further humanity moves away from animals, "the more they make their own history consciously" (330). No longer at the mercy of "unforeseen effects and uncontrolled forces" (330-331), human history is made in correspondence with "the aim laid down in advance" (331). In this way, Engels repudiates the sense of inevitability of so-called human progress, showing how materialist notions of history are consistent with what we assume to be natural.

\section{Reception in the Communist Sphere}

Dialectics of Nature was translated into Russian and published in the Soviet Union in 1925, which developed a "rigid application of Engels's three laws" (Royle 2014, 106). In 1929, scientific leaders gathered in Moscow to debate the virtues of dialectic materialists and the opposing school of idealists. Those supporting the dialectic position that scientific processes are "creative and synthetic" - ultimately "had a full victory", but this did not end the debate (Emery 1935, 11-12). By 1932, a prevailing notion that natural science is part of the ideological superstructure, akin to religion, and influences the means of production by fostering relationships was developed (Joravsky 1955, 5). Science instead should be seen as conditioned by "historical circumstances" and derives from a "world treasure-house" that is stocked by contributions from national communities, rather than individuals operating in a "cosmopolitan community of scientists".

After World War II, a sense of Soviet pride in national achievement and, with the rise of the cold war, antagonism toward the idea that so-called western civilization excludes Russian culture, "either implicitly or explicitly" (Joravsky 1955, 8-9). It is here that Dialectics of Nature is extrapolated to become a more direct critique of capitalism. As the cold war was about to get underway, though, Soviet communists took on a new target: Albert Einstein's theory of relativity. In June 1947, Andrei A. Zhdanov wrote about his concern that Einstein's theory was leading individuals to believe in a closed, finite universe (Hu 2005, 142). Although it is tempting to classify discounting of Einstein's work simply as wrong, we should take a page from Shapin and Schaffer (2011) and consider the nature of the controversy from an insider's point of view. For Russia, 
Einstein's work resulted in a network of nations that would restrict access to technology to reinforce the world system announced by U.S. Secretary of State George C Marshall in the same month that Zhdanov made his first statement. The next month, Soviet Foreign Minister V. M. Molotov would walk out of a meeting about the Marshall plan and initiate its own community of nations, the council for Mutual Economic Assistance.

China's interest in communism coincided with the reception of Dialectics of Nature. Starting in 1909, the U.S. used surpluses from the indemnity of the Boxer rebellion to fund science and engineering education for Chinese citizens. Shortly after the overthrow of the Qing Dynasty in 1912, people who might be called Boxer fellows formed a Chinese science society in 1914 and began publishing a journal, Kexue (科学 or science), the next year (Wang 2002, 294; 299). A famous formulation by Chen Duxiu arose in the early days of the Republic of China: Mr Science and Mr Democracy were the antidotes to the legacy of feudalism. In response to the failure to return the German holdings in Shandong province to China as part of the World War I peace process, intellectuals including Chen began seeking a political system that would help fight imperialism in what became known as the May Fourth movement in 1919. He would then go on to be one of the founders of the Communist Party of China (CPC) in 1921 and its general secretary until 1927. Although the appeal of gentlemanly Mr Science and Mr Democracy is understandable, it recalls the Internationale sentiment that China's communists lacked sufficient connection to the working class. Even so, Engels's Dialectics of Nature took on a special role at a time when Chinese intellectuals were trying to help their country recover after being left out of the industrial revolution thanks to the Opium Wars. Gao $(2016,270)$ says China sought to apply Engels's thought as a guide to transform the "agricultural nation to an industrialized power". Engels's chapter on "Labour in the Transition from Ape to Man" was translated into Chinese in 1928, and the whole of Dialectics of Nature was translated in 1932.

In 1956, the People's Republic of China adopted a long-term development plan that demanded the use of dialectics of nature. Mao Zedong himself addressed the topic in several essays (Guo 2014). As overseas Chinese scholars returned to the new PRC, they wished to provide guidance on how the development of science and technology might be ideologically different than they had known outside of China (Gao 2016). In other words, insights from Engels were used as a basis for science policy in the People's Republic. Engels's work took on new significance when it came to the attention of Mao Zedong that the Japanese, who could not match the Europe and the United States in equipment for nuclear research, nevertheless "had been able to propose a number of important hypotheses in elementary particle physics because they had read Engels's Dialectics of Nature" (Cheng 2013, 203). The idea that an atom's neutrons and protons could be divided into smaller parts reaffirmed the correctness of Engels's ideas and cemented for Mao the efficacy using dialectics in science. This led to a number of initiatives, perhaps the most famous being an attempt to criticise Einstein's ideas as bourgeois. This critique softened somewhat, and in 1973 the Journal of Dialectics of Nature was founded as a means to discuss Maoist theories of science (Cheng 2013, 213). This journal was disbanded in 1976.

Following Russia's lead, the CPC also initiated a campaign against Einstein. In the early 1950s, translations of Soviet criticism of Einstein found their way into newspapers. At first, Chinese scientists continued to "venerate" Einstein and point out the way his writing fit in with dialectical materialism (Hu 2005, 144). However, in the context of the cultural revolution, indigenous criticisms of Einstein arose. Writers noted that Einstein had served imperialism by helping create the atom bomb, as pointed out $\mathrm{Hu}$ (2005, 149-150), "which, in the hands of American imperialists, became a tool to blackmail and threaten socialist countries and other peace-loving countries in the world". Criticisms also were made of the way his theory negatively impacted the public's worldview. Hu $(2005,150)$ complains that it was widely known that Einstein did not 
directly participate in the Manhattan Project, but again the lessons from the BoyleHobbes debate should be followed here: while individuals may criticise the CPC for condemning relativity on ideological grounds, the concern was truly an effort to criticise bourgeois science, of which Einstein was the most famous emblem. In criticising Einstein in 1968, China hoped to inspire a proletarian science. By 1971, Premiere Zhou Enlai sought to soften the attack (Cheng 2013, 209). While some western observers seem gleeful in the way they discredit ideological influence on the development of science, it is not so radical to request that social considerations of science be taken into account.

After the cultural revolution, it became clear that finding people to develop plans for China's could be "overly ambitious" and government needed experts who could "develop a more realistic picture [...] and assess what it was possible to achieve in the near future" (Elzinga 1981, 19). In the period of market reform and opening up initiated by Deng Xiaoping, China moved away from what came to be seen as the rigid strictures of Soviet communism to form what he called "socialism with Chinese characteristics". Interestingly, the theories espoused by Engels took on an enhanced role after 1978, even if the three dialectical laws (negation and interpenetration of opposites, transition from quantity to new qualities, negation of the negation/Aufhebung [sublation]) were deemphasized.

The Chinese Society for the Dialectics of Nature was established in 1981, and a journal Research on Dialectics of Nature began publication in 1985. Although the PRC would embrace privatisation and market development, it still wished to do so in a responsible manner. The early days of the journal show enthusiasm for educational reform; STEM students were happy to see that their technical subjects were relevant to political philosophy of their country (Hou 1985). Scholars and journalists were invited to share their ideas in the first issue on how dialectics could guide the development of science and technology in China. In the second issue, one article described the development of Science and Technology Studies as a discipline outside of China (Jiang 1985). Another article analysed the US's big science system of funding scientific research (Yang and Zeng 1985). These articles represent both a speculative application of Engels's ideas as well as how their application might differ from capitalist contexts.

The contributors to this journal demonstrate the challenge faced by China after the cultural revolution, especially those represented in an anthology of English translations (Fan and Cohen 1996). Yu (1996) proposes that the 1915 formulations of Mr Democracy and Mr Science have been transformed by socialism into Comrade Democracy and Comrade Science (2). Similarly, Xu (1996) admits that science is the backbone of modern societies; all can see how science brings democratic ideals along with it. The difficulty is expunging from science bourgeois ideals that exploit science for "building up capitalist fortunes" (6). Science and democracy are both "precious spiritual legacies of the totality of human history" and the basis of Marxism (10). Looking back on the 1956 genetics conference in Qingdao, Li et al. (1996) praise the participants for fulfilling the CPC's promise of allowing one hundred schools of thought to flourish, writing, "science is international, a treasure belonging in common to all" (51). Conscious of how China was humiliated during the industrial revolution as well as the dangers of strictly following Soviet ideological constraints on science, the authors seek a new path that will support the development of science that does not serve as a means of exploitation.

"Introduction to Dialectics of Nature" became a compulsory course for STEM students. Guo $(2014,1838)$ does not speak favourably of the course, writing about his experience as student in 1996: 
While my teacher lectured, some students were absent, some students chatted, some students learned English, and some students did their homework for other courses. I estimate that the students who listened to my teacher in the classroom accounted for $50 \%$ of all students.

Guo's observations probably could be made of any required, non-major course in any country; we can also imagine many students sitting attentively in the front row.

Engels's thought inspired educators at a time when China's effort toward modernisation and the elimination of poverty began to show progress. Dialectics is still required of science and engineering students today, indicating that students who wish to advance their careers and interact well with the government can benefit from this subject, even if there may be some bored students in the back row of the classroom. As the country has focused on infrastructure development and improving their economic conditions in the Deng era (he is famous for saying "communism does not mean shared poverty"), the influence of Engels has been more on practical. As noted by Guo (2014, 1841 ) scholarship is likely to focus on "management, policies, and social problems".

One sociologist of science who visited China in 1980 wrote enviously of how the science of science, as he calls it, has the support of top leaders. In the U.S. and Europe, Weingart $(1981,14)$ writes, social studies of science "still struggles for institutional and professional support and recognition, Chinese scholars turning to that field do not have such worries" He goes on to write that in the U.S. and Europe, he and his colleagues "anxiously look to the natural sciences for approval [...] the science of science seems to have a bright future in China" (14-15). Due to the cold war and its aftermath, though, it is not easy to find this positive side.

\section{Dialectics in Capitalistic Science and Technology Studies}

Various manifestations of science and technology studies outside of China and Russia show similarities to the analyses inspired by Engels and implemented to support communist ideology. However, instead of finding common ground, some scholars have made a connection to political ideology, negatively assessing China's culture of science and engineering. One could turn this criticism around, saying that in capitalistic science, concern for human values is minimised due to the belief that science and technology are free from ideology and their impacts on the social fabric are beyond the purview of practitioners and institutions devoted to its practice.

The preface to the English translation by J. B. S. Haldane in 1939 pointed out the several positive aspects of Engels's analysis. Biologists after Haldane, including Stephen Jay Gould, Richard Dawkins, Richard Levins, and Richard Lewontin have praised Engels's insights (Royle 2014). Despite this commendation from a working scientist, Engels found little support among philosophers. György Lukács's footnote in his 1923 History and Class Consciousness is often cited to indicate the disdain the idea of dialectics existing in the natural science received (Foster 2013). In 1961, Jean Paul Sartre also bristled at the idea that human consciousness was a thing similar to the objects of nature (Remley 2012). These negative reactions seem to indicate that the way Engels's idea was received was to say that the dialectic between a human and an inanimate object was a flawed, dehumanising proposition. Lukács is willing to accept humans in a dialectic with history, but not with nature.

Increasingly, though, the use of Engels became identified with to interfere with scientific progress: shortly after Dialectics of Nature was translated into Russian, Merton (1938) was writing about a link between science and political ideals; to Merton, scientist must be "outraged" by any attempt to meet political aims (327). He goes on to advocate 
for the "purity of science," warning that science must not "become the handmaiden of theology or economy or state" (328). This mantle is taken up by others in the cold war. Mikulak (1958) suspects the "Communist party line" (49) and "philosophical restrictions upon Soviet astronomers" (50) have hindered science at the same time he writes that there are "no official statements" that CCCP approved or disapproved of any theories $(48)^{4}$. Similarly, Weiner (1985) writes of the way Dialectics of Nature became a dogma in the Soviet Union, and as a result, "the truth of natural science was subsidiary to the truth of Marxian 'science'” (689). Hu (2005) suggests that philosophy "was able to wantonly interfere" with science in China (186). Cao (2014) suggests that China cannot win Nobel Prizes because "China does not seem to believe [in] the existence of universally acknowledged values of science" and approaches science as "a pragmatic means to achieve the end of political leadership" (142). Engels's own warning, that science is operating in priestly worship of an unchanging universe, has done unheeded - indeed, it seems bolstered now as a passionate clergy in the face of evil.

The antipathy shown against Engels's dialectics is somewhat surprising given how much of the modern field of STS, like much critical theory, is based on a Marxist framework. After the notion of material history - the thinking that historical development is not inevitable and beyond the influence of humans direct - it is easier for a variety of critical theories that seek to show how what seem to be immutable characteristics of nature are really reification of ideologies. The dialectic between invention and society is clearly illustrated.

The STS concept of social constructivism in general seems indebted to Engels's Dialectic of Nature, even though few authors cite even Marxist ideas in general. Briefly speaking, the idea of social constructivism is that there are many simultaneous theories to explain phenomena or designs to solve technical challenges. This initial multiplicity is known as interpretative flexibility, meaning that the problem and its solutions have solutions that seem equivalent to the contemporary actors. Over a period of time, the relevant social groups find that some of the solutions fit in best with their ideals (thus reflecting economics, law, ideology, history, environment, and other factors of the social fabric). The common example of this is the formation of the so-called safety bicycle; who can go to a merchant and purchase an unsafe bicycle? This missing pole reflects the initial multiplicity of bicycle designs.

As STS proponents will tell us, there is no day in the nineteenth century to which we can return to find the supposed invention of the bicycle; instead, various actors proposed multiple designs that were simultaneous. After a time of stabilisation, the stunt bicycles that were favoured by the initial consumer group were supplanted by less risky models. As a marker of the culture at the time, gender differences were incorporated into the design, with a bicycle designed for women that had a low bar to accommodate their petticoats (Bijker 1995). The notion of co-creation can also be seen here. The low bar for women's bicycles was soon unnecessary because women began to wear more comfortable clothes. Nevertheless, the idea of a binary gender design had already been stabilized. This, when using this technology, a user must pick a gender, reinforcing norms of binary gender. In this example of co-creation, gender had an impact on design, and then the resulting design has a way of reifying the culture. The interplay of social and economic forces that gathered to create the modern bicycle design are also reminiscent of Engels, yet he is not cited by Bijker and most other main representatives of STS. Pickering $(1995,17$, footnote 26$)$ suggests without explanation

${ }^{4}$ Mikulak's paper was received by the journal in May 1957, a few months before the launch of Sputnik I showed that Soviet science was not as constrained by ideology as it might seem. 
in a footnote that the STS notion of co-creation of science and the social world is inspired by Engels. What seems like an obvious and necessary set of design choices what seems obviously to be a bicycle - is in fact the result of a conflicting set of assumptions that evolved over time seems nothing but a dialectical analysis.

Allied with social construction, the proponents of actor-network theory seem to ratify the idea that a complex interchange of ideology and history results in products that are always social. Latour and Woolgar (1986, 24), for instance, cite Marx's ideas of use value and of praxis in their foundational text Laboratory Life, but Engels and any mention of dialectics is unfortunately missing. They do, however, take on Merton, pointing out that he unjustly separates the scientific and the social worlds in what seems like a reaffirmation of Engels. Latour and Woolgar, embedded in Salk's vaccine laboratory, try to make an insider's view of science - doing an ethnographic study of what scientists do, as opposed to what they say they do. While scientists might claim that their inquiry is objective and free from social concerns, Latour and Woolgar point out that the devices they use are themselves cultural because they reflect the history of a discipline, not to mention the more obvious connection that the fact of setting an agenda and finding funding influences what will be investigated and how. In 1987, a group of scholars gathered at a workshop at the University of Twente in the Netherlands to explore the social analysis of technology that resulted in the first of several famous STS anthologies, Shaping Technology/Building Society. Bijker and Law (1992) in their introduction mention that technology is developed in conflict. Apart from the common assumption that technology is developed on its own, isolated from social concerns, the authors in this volume show how various solutions compete for audiences until one is established as the standard. After the initial conflict, the solution seems inevitable and unchangeable, almost a fact of nature.

In scientific fields, the impact of ideology that Engels predicted has been demonstrated many times, even if the authors seem not to know they are indebted to him. Galison (1985) uses the story of the bubble chamber in high-energy physics to show how the choice of a technology intersects the organisation and the substance of inquiry. As large-scale particle accelerators were made, however, the various options for conducting science collapsed onto bubble chambers. The paradigm in place for postWorld War II physics was the interdisciplinary, team-based approach of big science; even though researchers during the first phase could work individually or in teams, after the bubble chamber, it was only possible to do particle physics research in teams that numbered in the thousands. Schiebinger (1993) looks into the science behind the decision to exclude women from voting in the democratic revolutions in France and the United States. Surprisingly, she points to Linnaeus's decision to call humanity's portion of the animal kingdom mammals due to his belief that women should remain home to manage the private sphere while men went into the town to take care of business in the public sphere. Only with mammals, Schiebinger points out, was a sex-determinant characteristic found in only half of the population used as a name. Hacking (1999) takes on what would seem to be the least possibility for social construction - a rock only to show how tensions between authority, commercial use, and gender result in what seems to be the natural and obvious definition of dolomite. In a popular context, it would seem as if scientists are using an objective methodology to understand a stable and unchanging universe. Without critiquing capitalism directly, they point out that accepted technological designs and scientific findings are not inevitable and question the ideology of universal science.

Some STS thinkers who are more broadly known beyond STS circles do not cite Engels or Marx, even though they sound indebted to his thinking. Kuhn (1962) seems 
particularly indebted to the idea of dialectic even though he does not directly cite any of Marx's ideas. His famous notion of paradigm shift relies on some of the same observations noted by Engels in the history of astronomy. The idea that contradictions between normal science and new data likewise seem like a dialectical method. Pacey (1990) develops a concept he calls "technological dialogue" to describe the reason why technology does not easily transfer from one social circumstance to another. To understand the fact that both Asia and Europe had moveable type - and the reason why the earlier invention in China and Korea had a different impact than the much later invention in Germany - Pacey tells his readers to think about technology as a way of getting work done that carries ideology along with it instead of an inert device. As proof, he shows how at each stage of a device's diffusion, a "dialogue" takes place between the original circumstances and the new social context. This negotiation to resolve conflicts also seems indebted to a dialectical form of thinking.

These texts do not directly cite Dialectics of Nature and, although STS scholars often point out the internal contradictions of capitalistic science, they do not overtly make a critique of capitalism. It seems plausible that the use of Engels in the Soviet Union and the People's Republic of China and the tenuous position of science studies in universities has led these scholars to tread lightly during the Cold War. The connections, however, seem obvious. Despite the lack of Engels-citations, STS scholars certainly share with Engels the criticism of a single, unchanging reality and the notion of Enlightenment objectivity.

This self-censorship is less alarming that texts that directly address Marxist themes without understanding Engels's theory. Winner $(1977,82)$ makes the perplexing proposition that Dialectics of Nature promotes the idea that "individuals, classes, and societies have little autonomy to guide their own character or development" (82). MacKenzie and Wajcman $(1985,69)$ mention Engels obliquely in their commentary, crediting him unfairly for a non-dialectical notion that technology inevitably causes social change (69). Noble $(1997,87)$ seems to be inspired by Engels's observation that science failed to replace religious conceptions of nature, but he in fact criticises Marx for turning the quest for the means of production into a mechanism of spiritual "deliverance". Later, Noble (2011) gestures to Marx in the title and quotes him in epigraphs but makes little mention of communism and mentions neither Engels nor dialectics. Taking the lead from Merton (1938) and Mikulak (1958), these scholars either blame Engels for determinism or leave out obvious connections to their work, suggesting he is irrelevant ${ }^{5}$.

Engels's sense of managing the unintended consequences of technology choice has also been inspirational, even if he is not cited. In the foundational text of the appropriate technology movement, Schumacher (1973) discusses alienation, citing Marx, even if he suggests that Marx was wrong. Nevertheless, the interplay between technical development and its social consequences seems similar to Engels's analysis of technology. STS literature on feminist design involves experts getting into the minds of users and users participating in the design process as a means of distributing equity (Feldman 1999). Similarly, STS in the field of international development suggests how breaking down the inequality between the experts installing clean water systems and the citizens of developing countries can have a positive effect. Although an engineer might be focused on cost-effective systems that minimize the time to install and solve

${ }^{5}$ Bimber (1990) has carefully analysed three prominent forms of technological determinism in order to show that Marx does not fit into this category; he writes, "the intentional use of technology by human actors is an important theme in Marx's work, one quite contradictory in nature to technological determinism", continuing to say that whatever natural or inherent effects technology tends to produce are overcome by wilful human actions" (348). 
technical challenges elegantly, what experts think is a good project that will help people can have devastating effects on autonomy miss an opportunity to enhance local governance (Clemens et al. 2002). Like Engels, Schumacher and others also point out that technological development does not obligatorily demolish local culture, especially when one is willing to abandon the vaunted place of the expert and accommodate a variety of solutions.

Another way of implementing this idea is to consider how emphasising science without attending to social effects may not solve pressing contemporary issues. Tiles (1997), for one, notes that science is essential in reducing world hunger. However, philosophy has a role in directing the research, and Tiles cites Dialectics of Nature to show how the Chinese emphasis on interconnectedness is necessary. She writes:

There is nothing particularly scientific or particularly rational in the way of proceeding to try to solve all practical problems by developing a product in a research laboratory, through the application of theoretical science, presuming that it can be put out into the world for universal application. This makes sense only for those who can presume unlimited resources (to pay the costs of suitably modifying the environment so that it at least approximates the conditions of the laboratory in which the development work was carried out) and in areas where it can be presumed that the simplifications in the problem specification necessarily entailed by such a strategy have not omitted factors crucial to the success of implementation of the 'solution' in real world situation (Tiles 1997, S173).

Because the reward systems and goals of institutional science are not organized to benefit the poor, science is unlikely to solve problems like world hunger, Tiles writes.

\section{Implications for Future Work}

As this paper has shown, it is clear that Engels was not, in fact, trying to remove human agency or create an alternative form of science. Instead, we can see how his critique of idealism in science is still relevant to critical thinking about STEM today. The problems he witnesses in the exploitative science at the behest of capitalism during the age of colonialism resonate only more strongly in our technological age. Making this connection has two important implications. For one, it opens a channel for collaboration between STS scholars inside and outside China, particularly those who are interested in strategies for sustainable development.

First of all, understanding Engels's dialectic method can help build bridges between STS researchers within and outside of China. China's success in alleviating poverty particularly under Deng's rubric of socialism with Chinese characteristics in the years since 1978 - has been guided by Engels's insights. Unfortunately, the ability of science and technology policy to produce sustainable and equitable development seems like a fringe theory outside of China. It is in this domain that Engels's critique can be used today. As a counter to histories of the Internet that suggest the kernel of an idea in the heart of the military-industrial complex spread out to become a technology that welcomed all humans, a dialectical method can show the competing forces, both within the U.S. and without, that forged the Internet. Similarly, dialectical thinking can help problematise simplistic thinking about the opportunities that supposedly come from unleashing the unidirectional power of technology worldwide.

Secondly, Dialectics of Nature points toward an opportunity to revisit current trends in engineering education. One key notion is adding the liberal arts to provide an interdisciplinary science and engineering education, a practice known as STEAM. Taking 
the acronym developed by the U.S. National Science Foundation for science, technology, engineering, and management (STEM), Yakman (2008) suggested that educators should incorporate the arts, adding A to STEM to get STEAM. There is a practical side to this proposal; it is in the arts and crafts classroom where students can build things. Several proposals have been made to take the materials and skills used in a middle school classroom to provide scientific investigation (Gilbert and Borgerding 2019). Although Yakman was quite open in her intention to include ideas about history and sociology in her paradigm for STEAM, even a cursory review of the literature shows how this project has been derailed by well-meaning educators who have transformed STEAM with ideologies of the "maker" movement to teach students job skills. Allington et al. (2016), for instance, have criticised the maker movement in the humanities when its proponents "disavow scholarly endeavor that is overtly critical of existing social relations". The intellectual tradition established by Engels can serve as a useful counter to the effort to end critical thinking in the humanities with neo-liberal goals of making education relevant to the job market.

The polarization of the Cold War still has its effects today in STS because of the mistaken notion that Marxism seeks to remove human agency from the process of history. This misreading is easily seen by studying Engels's thoughts on applying dialectics to science. Although he clearly resents the division of labour in science and the ways in which bourgeois notions limited scientific progress, he does not see science as inevitably a bourgeois pursuit. He writes:

The men who founded the modern rule of the bourgeoisie had anything but bourgeois limitations. On the contrary, the adventurous character of the time inspired them to a greater or lesser degree. There was hardly any man of importance then living who had not travelled extensively, who did not speak four or five languages, who did not shine in a number of fields.... The heroes of that time were not yet in thrall to the division of labour, the restricting effects of which, with its production of one-sidedness, we so often notice in their successors. But what is especially characteristic of them is that they almost all live and pursue their activities in the midst of the contemporary movements, in the practical struggle; they take sides and join in the fight, one by speaking and writing, another with the sword, many with both (Engels 1925, 319-320).

Thanks are due in part to the Soviet and Chinese intellectuals who saw in Engels an opportunity to counter what seemed like an inevitable march of technical development with the sense that human beings could monitor and redirect the forces shaping society. Additionally, the efforts of reform-minded intellectuals outside of communist countries show a way of understanding that the impact of science and technology is not inevitable.

\section{References}

Allington, Daniel, Sarah Brouillette, and David Golumbia. 2016. Neoliberal Tools (and Archives): A Political History of Digital Humanities. Los Angeles Review of Books, 1 May 2016. https://lareviewofbooks.org/article/neoliberal-tools-archives-political-history-digitalhumanities/

Bijker, Wiebe E. 1995. Of Bicycles, Bakelites, and Bulbs: Toward a Theory of Sociotechnical Change. Cambridge, MA: The MIT Press.

Bijker, Wiebe E. and John Law, eds. 1992. Shaping Technology/Building Society: Studies in Sociotechnical Change. Cambridge, MA: The MIT Press. 
Bimber, Bruce. 1990. Karl Marx and the Three Faces of Technological Determinism. Social Studies of Science 20 (2): 333-351.

Cao, Cong. 2014. The Universal Values of Science and China's Nobel Prize Pursuit. Minerva 52 (2): 141-160.

Chamberlain, Muriel E. 2013. The Scramble for Africa [3rd Edition]. London: Routledge.

Cheng, Yinghong. 2013. Ideology and Cosmology: Maoist Discussion on Physics and the Cultural Revolution. In Mr Science and Chairman Mao's Cultural Revolution: Science and Technology in Modern China, edited by Chunjuan Nancy Wei and Darryl E. Brock, 197231. New York: Lexington Books.

Clemens, Bruce, Andrew W. Karp, and Maria Papadakis. 2002. The People's Water: Technology Transfer and Community Empowerment in Guatemala. In Research in Science and Technology Studies, Vol. 13, edited by Marianne de Laet, 105-127. New York: JAI.

de Sousa Santos, Boaventura. 2018. The End of the Cognitive Empire: The Coming of Age of Epistemologies of the South. Durham, NC: Duke University Press.

Desmond, Adrian and James Moore. 2011. Darwin's Sacred Cause: How a Hatred of Slavery Shaped Darwin's Views on Human Evolution. Chicago: University of Chicago Press.

Elzinga, Aant. 1981. The Science of Science in China: Report by a Specialist in Science Policy. Science, Technology, \& Human Values 6 (35), 18-21.

Emery, A. 1935. Dialectics versus Mechanics. A Communist Debate on Scientific Method. Philosophy of Science 2 (1): 9-38.

Engels, Friedrich. 1925. Dialectics of Nature. In Marx \& Engels Collected Works (MECW) Volume 25, 311-588. London: Lawrence \& Wishart.

Fan, Dainian and Robert S. Cohen, eds. 1996. Chinese Studies in The History and Philosophy of Science and Technology. Dordrecht: Springer.

Feldman, Roberta M. 1999. Participatory Design at the Grass Roots. In Design and Feminism: Re-visioning Spaces, Places, and Everyday Things, edited by Joan Rothschild, 135148. New Brunswick: Rutgers.

Foster, John Bellamy. 2013. Marx and the Rift in the Universal Metabolism of Nature. Monthly Review 65 (7). Accessed 13 November, 2020. https://monthlyreview.org/2013/12/01/marx-rift-universal-metabolism-nature/

Galison, Peter. 1985. Bubble Chambers and the Experimental Workplace. In Observation, Experiment and Hypothesis in Modern Physical Science, edited by Peter Achinstein and Owen Hannaway, 309-372. Cambridge, MA: The MIT Press.

Gao Lu. 2016. From Dialectics of Nature to STS: The Historical Evolution of Science Studies in China. In Science Studies During the Cold War and Beyond, edited by Elena Aronova and Simone Turchetti, 267-288. New York: Palgrave.

Gilbert, Andrew and Lisa Borgerding. 2019. Possibilities and Potential with Young Learners: Making a Case for STEAM Education. In STEM Education: An Emerging Field of Inquiry, edited by Tasos Barkatsas, Nicky Carr and Grant Cooper, 101-116. Boston: Brill Sense.

Guo, Yuanlin. 2014. The Philosophy of Science and Technology in China: Political and Ideological Influences. Science and Education 23 (9): 1835-1844.

Hacking, lan. 1999. The Social Construction of What? Cambridge, MA: Harvard University Press.

Hou, Jixia 侯吉侠. 1985. Engineering College Students Welcome Dialectics of Nature 工科大 学生欢迎自然辩证法. Research on Dialectics of Nature 1: 62-64.

Hu, Danian. 2005. China and Albert Einstein: The Reception of the Physicist and his Theory in China 1917-1979. Cambridge, MA: Harvard University Press.

Jiang, Zhenhuan 姜振寰. 1985. Survey of Research on History of Technology Abroad 国外技 术史研究概况. Research on Dialectics of Nature 2: 70-74.

Joravsky, David. 1955. Soviet Views on the History of Science. Isis 46 (1), 3-13.

Kuhn, Thomas S. 1962. The Structure of Scientific Revolutions. Chicago, IL: University of Chicago Press. 
Latour, Bruno and Steven Woolgar. 1986. Laboratory Life. Princeton, NJ: Princeton University Press.

Li, Peishan, Meng Qinzhe, Huang Qinghe and Huang Shu'e. 1996. The Qingdao Conference of 1956 on Genetics: The Historical Background and Fundamental Experiences. In Chinese Studies in The History and Philosophy of Science and Technology, edited by Dainan Fan and Robert S. Cohen, 41-54. Dordrecht: Springer.

MacKenzie, Donald and Judy Wajcman, eds. 1985. The Social Shaping of Technology: How the Refrigerator Got Its Hum. Philadelphia: Open University Press.

Merton, Robert K. 1938. Science and the Social Order. Philosophy of Science 5 (3): 321-337.

Mikulak, Maxim W. 1958. Soviet Philosophic-Cosmological Thought. Philosophy of Science 25 (1): 35-50.

Noble, David F. 2011. Forces of Production: A Social History of Industrial Automation. New Brunswick, NJ: Transaction.

Pacey, Arnold. 1990. Technology in World Civilization. Cambridge, MA: The MIT Press.

Pickering, Andrew. 1995. The Mangle of Practice: Time, Agency and Science. Chicago: University of Chicago Press.

Remley, William L. 2012. Sartre and Engels: The Critique of Dialectical Reason and the Confrontation on the Dialectics of Nature. Sartre Studies International 18 (2): 19-48.

Royle, Camilla. 2014. Dialectics, Nature and the Dialectics of Nature. International Socialism 141: $97-118$.

Schiebinger, Londa. 1993. Nature's Body: Gender in the Making of Modern Science. Boston, MA: Beacon.

Schumacher, Ernst F. 1973. Small is Beautiful: A Study of Economics as if People Mattered. London: Blond and Briggs.

Shapin, Steven and Simon Schaffer. 2011. Leviathan and the Air-Pump: Hobbes, Boyle, and the Experimental Life. Princeton: Princeton University Press.

Tiles, Mary. 1997. Science and the Politics of Hunger. Philosophy of Science 64, Supplement. Proceedings of the 1996 Biennial Meetings of the Philosophy of Science Association. Part II: Symposia Papers, S161-S174.

Wang, Zuoyue. 2002. Saving China Through Science: The Science Society of China, Scientific Nationalism, and Civil Society in Republican China. Osiris 17, 291-322.

Weiner, Douglas R. 1984. Community Ecology in Stalin's Russia: "Socialist" and "Bourgeois" Science. Isis 75 (4), 684-696.

Weingart, Peter. 1981. The Science of Science in China: Report by a Sociologist of Science. Science, Technology, \& Human Values 6 (2): 14-17.

Whewell, William. 1840. The Philosophy of the Inductive Sciences, Founded upon their History, Volume 1. London: John W. Parker.

Winner, Langdon. 1977. Autonomous Technology: Technics-out-of-Control as a Theme in Political Thought. Cambridge, MA: MIT Press.

Xu, Liangying. 1996. Essay on the Role of Science and Democracy in Society. In Chinese Studies in The History and Philosophy of Science and Technology, edited by Dainian Fan and Robert S. Cohen, 5-11. Dordrecht: Springer.

Yakman, Georgette. 2008. ST $\sum @ M$ Education: An Overview of Creating a Model of Integrative Education. In Proceedings of the Pupils' Attitudes Towards Technology (PATT-19) Conference: Research on Technology, Innovation, Design \& Engineering Teaching, 335358. Salt Lake City: ITEEA.

Yang, Di 杨迪 and Zeng Guoping 曾国屏. 1985. Exploration of American Science and Technology Strategy in the 1980s 八十年代美国科技战略的探索. Research on Dialectics of Nature 2: 75-76.

Yu, Guangyuan. 1996. On the Emancipation of the Mind. In Chinese Studies in The History and Philosophy of Science and Technology, edited by Dainan Fan and Robert S. Cohen, 1-3. Dordrecht: Springer. 


\begin{abstract}
About the Author
Christopher Leslie

Christopher Leslie is the chair of the International Federation of Information Processing's working group on the History of Computing (http://ifipwg97.org) and Creative Consultant for Zhejiang Hexin Group in Yunhe, China. A two-time winner of a Fulbright fellowship, he has taught at Hunter College, John Jay College, New York University, Polytechnic University, Universität Potsdam, and the South China University of Technology. Dr Leslie was born and raised in western New York State. He took his M.A. and Ph.D. from the City University of New York Graduate Center in New York City. His research interests include the interactions among science, technology, and culture.
\end{abstract}




\title{
Break or Continuity? Friedrich Engels and the Critique of Digital Surveillance
}

\author{
Dimitrios Kivotidis
}

University of East London, London, UK, d.kivotidis@uel.ac.uk

\begin{abstract}
This paper is a contribution to the argument that Engels's work remains topical and may provide us with the analytical tools necessary to approach contemporary manifestations of capitalist contradictions. Based on Engels's work on political economy (with emphasis on his contribution to the labour theory of value and the articulation of the law on the tendency of the rate of profit to fall) it will critically review the concept of "surveillance capitalism" as developed by Shoshana Zuboff, in order to explain central aspects of the process of digital surveillance. In particular, it will criticise the view expressed by Zuboff that surveillance capitalism constitutes a break with capitalism's past and can be tamed through an enhancement of democratic accountability and regulation. Marxist contributions to the critique of digital surveillance have already approached this phenomenon in a many-sided manner. This paper builds upon these contributions and suggests that the exponential growth of digital platforms can be explained as a direct result of the development of capitalist contradictions, especially the contradiction between productive forces and relations of production as expressed in the law of the falling rate of profit.
\end{abstract}

Keywords: Friedrich Engels, digital surveillance, surveillance capitalism, turnover time, rate of profit

\section{Introduction}

This year marks two hundred years since the birth of Friedrich Engels, one of the Dioscuri of Marxist thought. By the time of his death, seventy-five years later, Engels had contributed greatly to the scientific analysis of social processes as well as to the growth and theoretical equipment of the international working-class movement. However, for the greater part of the period since his death, Engels's work has received scorn and has been subject to waves of attacks - often from within "leftist" or "Marxist" currents. These attacks focus on various aspects of his work (on the dialectics, on political economy, on the state, etc.) and for the most part aim to dissociate Engels from Marx, claiming that the former distorted the work of the latter. In doing so they aim to discredit the revolutionary and scientific credentials of Marxist thought.

Indeed, one of the main characteristics of Engels's - as well as Marx's - work is its commitment to base the revolutionary critique of capitalism on firm and rigorous scientific analyses and not just on moral condemnation. This paper claims that Marx and Engels's analysis of capitalism is still appropriate and necessary to analyse contemporary phenomena and processes, such as the process of digitalisation of the public and private sphere.

This paper will critically review the concept of "surveillance capitalism" as developed by Shoshana Zuboff in order to explain central aspects of the process of digitalisation. In particular, based on Engels's work on political economy (with emphasis on his contribution to the labour theory of value and the articulation of the law on the tendency of the rate of profit to fall) it will criticise the view expressed by Zuboff that surveillance capitalism constitutes a break with capitalism's past and can be tamed 
through an enhancement of democratic accountability and regulation. Zuboff's analysis fails to comprehensively grasp the totality of implications of the process of digitalisation, as she disregards the issue of exploitation and the centrality of the contradiction between productive forces and productive relations.

Despite several attacks on Engels's role in the publication of Capital, it is well established that his work was essential for the rigorous application of Marxist analysis to various fields (Gould 1977; Waitzkin 1983; Lewontin and Levins 1985). Engels was a pioneer in the development of the dialectical materialist analysis of social processes and phenomena, central tenets of which, such as approaching a social formation as a totality and ascribing centrality to the role of productive relations, are crucial for grasping the social effects of the processes of automation and digitalisation. Capitalist productive relations determine how the forces of production are put to use and the laws of motion of capitalist economy necessitate the processes of exploitation and realisation of surplus value, which determine the operation of phenomena that Zuboff describes under the term "surveillance capitalism".

This paper argues that Engels's work on political economy, focusing on the contradiction between productive forces and relations of production, is key for grasping that phenomena and processes described under the term "digital" or "surveillance capitalism" do not constitute a break with capitalism's past, but result from the historical development of tendencies inherent in the laws of motion of the capitalist mode of production. To do so it draws attention to one particular aspect of Engels's contribution: the effect of turnover time on profitability. This aspect of the Marxist critique of political economy has not been adequately developed. The importance of turnover time reduction for understanding the development of "surveillance capitalism" is hinted at by certain Marxist thinkers. It is this paper's modest contribution, celebrating the thought of one of the founders of Marxism, to explicitly articulate the importance of this aspect of Engels's analysis of capitalism for the understanding of the process of digitalisation and invite further research from a Marxist standpoint on this issue.

On this basis the paper is structured in three sections. The first section synoptically presents Engels's contribution to the critique of political economy, focusing on the theory of crisis and the contradiction between productive forces and relations of production. The section concludes with a presentation of Engels's elaboration on the relationship between turnover time and profitability. The next section critically discusses Zuboff's concept of "surveillance capitalism" from a Marxist standpoint. In particular, using Engels's methodological approach of the capitalist social formation as a totality with focus on the sphere of production, we shall criticise Zuboff's claim that "surveillance capitalism" constitutes "a break with capitalism's past" or "a coup from above", arguing that it is rather a result of the developing contradiction between productive forces and capitalist relations of production. The last section will present alternative views on digital surveillance from a Marxist standpoint and examine how exactly they contribute to a more comprehensive analysis of these processes and phenomena, as well as how Engels's work has influenced and can further influence these approaches.

\section{Engels on Political Economy}

\subsection{Attacks on Engels's Work}

This paper argues that Engels's work remains topical and contains elements whose implications and significance for analysing contemporary phenomena and processes are not fully explored. Of course this view contradicts the waves of attacks that his 
work has been subjected to for many decades. Therefore, a synoptic review of the main points of these attacks is pertinent here in order to highlight our claim. It has been argued that an "anti-Engels outlook" emerged as defining characteristic of the Western academic left (Foster 2017). The axiomatic opposition of "Western Marxism" to Engels's work can be summed up in the following points.

The first concerns Marxist epistemology and method of analysis, i.e. dialectical materialism. Engels is accused of misrepresenting Marx's dialectics as a mechanistically objective method and of trying to imprison Marx's free critical spirit in the cage of a standardised system (McLellan 1977; Carver 1984). More specifically, Engels is considered responsible for introducing positivism into Marxism, eventually leading to the positivism of the Second and Third Internationals and Stalinism (McLellan 1977). Directly linked to this is the accusation that Engels committed the sin of promoting "quasi-Hegelianism, materialism, [...] and dialectics" which are "miles away from Marx's painstaking eclecticism" (Carver 1984, 278).

This point echoes the post-war Western philosophical axiomatic opposition to the objectivity of dialectics, i.e. to the objective existence of contradiction in natural and social phenomena and processes that dialectical logic approaches and analyses (llyenkov 2020; Losurdo 2004). It also introduces the opposition between Marx, a liberal and refined intellectual, and Engels, a coarse populariser. Pitting Marx against Engels ultimately serves a similar purpose as pitting "young Marx" against the "old Marx" (Althusser 2006), or pitting "young Lenin" against "old Lenin" (Anderson 1995), or pitting Lenin against Marx, and so on and so forth. This formal opposition betrays the rejection of and attack on the revolutionary elements and scientific credentials of Marxist analysis. It has, therefore, not just philological but also theoretical and political implications.

Another current, which has directed their attacks on Engels's work on political economy, is led by the Neue Marx Lektüre (New Reading of Marx) authors (Mavroudeas 2020). According to this current, Engels distorted Capital with unwarranted interventions by misrepresenting it as a finished work when in reality it was just an incomplete research project (Heinrich 1996/97). The crux of this critique is the attack on Marx's theory of economic crises. Engels is accused of ascribing to Marx a theory of economic crisis based on the Law of the Falling Rate of Profit (LFRP), whereas the latter supposedly stopped adhering to this law from some point onwards (Heinrich 2016).

The political implications are palpable here as well. Whether Marx had developed a coherent theory of crisis is a matter of intense theoretical and political debate (Heinrich 2013; Roberts 2013). The most dominant interpretations of crises of capitalist production consider them as due to "underconsumption", i.e. a lack of spending by workers who do not have enough to spend, or due to "disproportion", i.e. the anarchy of capitalist production whereby production in various sectors can get out of line with others and can outstrip demand, or due to the lack of profitability in an economic system that depends on profit being made for private owners in order for investment and production to take place (Roberts 2015).

The political implication of the first two interpretations is that capitalist crises are susceptible to Keynesian solutions of full employment and regulation, i.e. capitalism can be saved from itself through reforms. According to the third interpretation crises in capitalism are inevitable due to contradictory nature of the capitalist mode of production. This of course does not prove that the supersession of capitalism is inevitable, but shows the instability of the capitalist mode of production which tends towards 
constant immiseration of the popular strata. The counter-acting factors reproduce capitalism at the cost of dehumanisation.

\subsection{Engels's Critique of Capitalist Contradictions}

We shall now turn to the main elements of Engels's work on political economy, in order to show how his and Marx's analyses approached the contradictions of the capitalist mode of production and highlight their insights which are relevant for the analysis of contemporary processes and phenomena. To begin with, Engels stressed the point that a critique of the capitalist mode of production cannot be reduced to moral condemnation. The task of a socialist critique of capitalism is the scientific exposition of its laws in order to demonstrate "that this mode of production, by virtue of its own development, drives towards the point at which it makes itself impossible" (Engels $1878,138-139)$. In other words, the essence of the scientific analysis of capitalism is the exposition of the contradictions inherent in this mode of production.

These contradictions are generally expressed in the form of the contradiction between productive forces and relations of production. According to Engels, the socialist critique of capitalism is tasked with proving that capitalist relations of production hinder the development of productive forces. One can, for instance, consider how the technological developments of automation and digitalisation in capitalism tend to result in unemployment and a quantitative and qualitative devaluation of labour power.

Engels's materialist approach points to the primacy of productive relations in order to understand and analyse phenomena in the sphere of distribution, which are eventually perceived as phenomena of injustice: "the manner in which wealth is distributed and society divided into classes or orders, is dependent upon what is produced, how it is produced, and how the products are exchanged" (Engels 1878, 135136; Engels 1880, 306). Nevertheless, the processes and relations of distribution are "not a merely passive result of production and exchange"; in its turn distribution reacts upon both of these (Engels 1878, 137). What is more, differences in distribution manifest themselves as class differences: "Society divides into classes; the privileged and the dispossessed, the exploiters and the exploited, the rulers and the ruled" (Engels 1878, 136-137). These class divisions determine the growing perception that "existing social institutions are unreasonable and unjust" (Engels 1880, 306). However, this "is only proof that in the modes of production and exchange changes have silently taken place, with which the social order, adapted to earlier economic conditions, is no longer in keeping" (Engels 1880, 306).

It follows from the above that, according to Engels, capitalist social relations have to be approached as a totality whose different aspects are in constant interaction with each other. Additionally, we can also deduce the materialist principle according to which the perception of injustice is proof of the contradiction between productive forces and relations of production. The dialectics of capitalism is an objective dialectics: "the conflict between productive forces and modes of production [...] exists, in fact, objectively, outside us, independently of the will and actions even of the men that have brought it on" (Engels 1880, 307).

The contradiction between productive forces and relations of production manifests itself in different forms, such as the contradiction between the concentration and socialisation of the productive process and the individual ownership of means of production. This contradiction, which "gives to the new mode of production its capitalistic character" and "contains the germ of the whole of the social antagonisms of today" (Engels 1880, 310), manifests itself also as "the antagonism of proletariat and bourgeoisie" (Engels 1880, 311). Furthermore, it "presents itself as an antagonism be- 
tween the organisation of production in the individual workshop and the anarchy of production in society generally" (Engels 1880, 313). This anarchy in production is responsible for the transformation of the "great majority of men into proletarians", as well as for the transformation of machinery from potential liberator of humanity from the shackles of necessity into "the most powerful weapon in the war of capital against the working-class" which constantly tears "the means of subsistence out of the hands of the labourer" (Engels 1880, 315).

Last but not least, Engels sketches out the contradiction between "the enormous expansive force of industry" (which is driven by the need for valorisation and expanded reproduction of capital) and the resistance offered "by consumption, by sales, by the markets for the products of modern industry", the extension of which "cannot keep pace with the extension of production" (Engels 1880, 315).

\subsection{The Law of the Falling Rate of Profit}

Another manifestation of the contradiction between productive forces and productive relations, albeit one that Engels does not explore in his individual works but one that his work was crucial in articulating, is the law of the tendency of the rate of profit to fall (LFRP). According to this law, the value of the means of production (machinery, offices and other equipment) will, over time, rise relative to the value of labour power (the cost of employing a labour force) (Roberts 2015). Marx called this process the rising organic composition of capital (Marx 1894, 317-338). However, since value (and profit) is only created by labour power, the value produced by labour power will, over time, decline relative to the cost of investing in means of production and labour power. In other words, the ratio of surplus value to the total capital (i.e. the sum of constant capital corresponding to the value of raw materials and means of production and variable capital corresponding to the value of labour power) advanced by the capitalist will tend to diminish. Consequently the rate of profit will tend to fall (Roberts 2015).

It has to be noted that the law appears as a tendency because of the operation of various countertendencies. These include the intensification of exploitation of labour power, the depression of wages below the value of labour power, the cheapening of the value of constant capital, foreign trade, etc. (Marx 1894, 338-348). These countertendencies do not abolish the law but they cause it to "operate more as a tendency, i.e. as a law whose absolute realisation is held up, delayed, and weakened, by counteracting factors" (Marx 1894, 335). Nevertheless, Marx seemed to be certain that the rate of profit would fall as a result of the development of productivity (Moseley 2018, 103) and thus that the capitalist productive relations would become the real barrier for the development of productive forces (Marx 1857/1858, 749): "The true barrier to capitalist production is capital itself' (Marx 1894, 358).

In a letter to Engels in 1868, Marx referred to the law as "one of the greatest triumphs over the pons asini of all previous political economy" (Marx 1868, 24). This says a lot about the explanatory value of the LFRP. For instance, a compelling argument has been made that the cause of recurring and regular economic crises or slumps in output, investment, and employment in modern economies can be found in the LFRP (Carchedi and Roberts 2018). One could go even further than that and advance the hypothesis that the LFRP is key to explaining most contemporary developments of the capitalist mode of production in its imperialist stage, i.e. off-shoring, relative de-industrialisation, financialisation, digitalisation and automation, neoliberalism and labour deregulation, etc. 
This is not the place to develop, let alone test, such a multifaceted hypothesis, but it is of direct interest to us, on the contrary, to discuss Engels's role in the discovery and articulation of this law. The discovery of the law itself is of course attributed to Marx. However, since the law is presented in the third volume of Capital, which was edited by Engels and published after Marx's death, Engels's contribution to its articulation cannot be denied. In general, the streamlining of Marx's notebooks into the second and third volumes of Capital has been described as an "unmitigated feat" and "major contribution" of Engels in political economy (Mavroudeas 2020). Regarding the third volume in particular, it has been argued that Engels's editing makes Marx's manuscript look much more complete and organised than it actually was, but he mostly did not change the content of what Marx wrote (Moseley 2015, 41).

As far as the LFRP is concerned, the role of Engels is central to the debate about Marx's relation to the law itself. As we saw above, it is argued that Marx had stopped adhering to the law and Engels is accused of making "far too much of Marx's law" and distorting Marx's view on this (Heinrich 2016; Roberts 2015). This view is refuted by the aforementioned letter to Engels, but also by a close examination of Engels's work and editorial changes on Marx's writing on the law. On this basis, it is argued that Engels did not overemphasise the importance of the law. On the contrary, he actually made it appear that Marx balances the countertendencies in equal measure with the law as such, when the original order of the text reemphasises the law after talking about counter-influences (Seigel 1978, 339). Engels's interventions did not distort Marx's drafts but rather made them appear sharper and thus more useful for contemporary political and societal debate (Roth and Moseley 2002, 11).

We conclude this brief exposition of Engels's valuable contribution to the critique of political economy with reference to what has been characterised as the hidden gem of his contribution, i.e. his focus on the effect of the turnover of capital in relation to profitability (Mavroudeas 2020). This is explored in Chapter IV of the third Volume of Capital, which is now recognised as having been written exclusively by Engels (Moseley 2015, 13). According to Engels then, the quantity of produced surplus value is augmented by reductions in the period of turnover, because the shorter the period of turnover the smaller the portion of capital that sits idly and the larger the appropriated surplus value, all other conditions remaining the same (Marx 1894, 163). "But since the rate of profit simply expresses the ratio of the mass of surplus value produced to the total capital engaged in producing it, it is evident that any reduction of this kind raises the rate of profit as well" (Marx 1894, 163). It follows then that any methods which contribute to a reduction in turnover time can be considered factors that counteract the LFRP. This is an important point for the argument developed in the following sections.

Since the cycle of accumulation consists of the production process and the circulation process, it follows that for the turnover time to be reduced the cycle of production and/or the cycle of circulation have to be accelerated. According to Engels, the reduction of production time is predominantly achieved through higher labour productivity, whereas the reduction of circulation time is predominantly achieved through improved communications. Regarding the latter, Engels refers to eighteenth-century developments (railway, steamboat line, telegraph wires, Suez Canal) that radically reduced the time of circulation (Marx 1894, 164). This paper argues that following the same logic we can understand recent developments, such as digital surveillance, targeted advertising, data mining, etc., as serving the purpose of reducing turnover time and constituting factors that counter the LFRP. 


\section{Zuboff's Surveillance Capitalism}

Let us now turn to one of the most widely read and highly praised analyses of the process of digitalisation, i.e. Shoshanna Zuboff's work on surveillance capitalism. Zuboff provides us with several definitions of surveillance capitalism. She speaks of "a new economic order that claims human experience as free raw material for hidden commercial practices of extraction, prediction, and sales"; "a parasitic economic logic in which the production of goods and services is subordinated to a new global architecture of behavioural modification"; "a rogue mutation of capitalism marked by concentrations of wealth, knowledge, and power unprecedented in human history"; "the origin of a new instrumentarian power that [...] presents startling challenges to market democracy"; "an expropriation of critical human rights that is best understood as a coup from above: an overthrow of the people's sovereignty" (Zuboff 2019, v).

Several points can be raised regarding this extensive definition of surveillance capitalism. First, the vague signifiers "new economic order", "new economic logic", "origin of a new instrumentarian power" attest to the difficulty of defining this concept. It is hard to define what makes "surveillance capitalism" a distinct form of capitalism. Furthermore, Zuboff's attempts at defining "surveillance capitalism" as capitalism's rogue mutation betray the author's choice of a Keynesian framework which focuses on the concentration of wealth and the ensuing wealth inequalities, and not on the issue of exploitation. In other words, its one-sided focus on distributive relations is the exact opposite to Engels's approach of capitalist social relations as a totality, where productive relations play a predominant role.

Nevertheless, the reference to the parasitic nature of surveillance capitalism is framed in terms of a pseudo-Marxist argument. Surveillance capitalism's parasitic nature "revives Karl Marx's old image of capitalism as a vampire that feeds on labour", but instead of labour it "feeds on every aspect of every human's experience" (Zuboff 2019, 9). Zuboff employs certain quasi-Marxist categories but the core of her analysis could not be further from Marxism. She explicitly confirms this by claiming that existing categories, such as "monopoly" or "privacy" are inadequate to comprehend this "new economic logic" (Zuboff 2019, 14).

Let us take the example of the term "behavioural surplus" which heavily features in Zuboff's analysis and is reminiscent of "surplus value" especially when combined with the "new means of production", i.e. machine intelligence which renders this surplus. This term is central for Zuboff, as she claims that surveillance capitalism begins with the discovery of behavioural surplus (Zuboff 2019, 97). It is never explicitly defined, but it can be inferred as meaning that "more behavioural data are rendered than required for service improvements" (Zuboff 2019, 97). Zuboff claims that up until a certain point behavioural data were collected by digital corporations and put to work entirely on the user's behalf; she calls this the "behavioural value reinvestment cycle" (Zuboff 2019, 69). With the discovery of behavioural surplus, raw materials which until that point were solely used to improve the quality of search results were then put to use in the service of targeted advertising to individual users (Zuboff 2019, 74).

However, the term "behavioural surplus" has little analytical value as it does not explain the reasons for its discovery by surveillance capitalists or the antagonisms that its extraction entails, as we shall see in the following sections. For Marx, surplus value is the raison d'être of the capitalist mode of production; capitalism does not exist without the constant reproduction of conditions for surplus value extraction. Contrariwise, for Zuboff digital monopolies can somehow revert back to the "behavioural value reinvestment cycle" if they decide not to collect and render behavioural surplus and focus instead on use of data for service improvement. 
The core of Zuboff's argument is that "surveillance capitalism unilaterally claims human experience as free raw material for translation into behavioural data" (Zuboff $2019,8)$. This "behavioural surplus" is fed into the means of production of this new economic order, i.e. the advanced manufacturing processes known as "machine intelligence" (Zuboff 2019, 8; 95-96). The result of this process is "prediction products", which "anticipate what you will do now, soon, and later" and "are traded in a new kind of marketplace for behavioural predictions" called "behavioural futures markets" (Zuboff 2019, 8). Through the extraction and selling of behavioural data, surveillance capitalists are increasingly intervening "in the state of play in order to nudge, coax, tune, and herd behaviour toward profitable outcomes" (Zuboff 2019, 8).

The above contains very useful insights on the role of digitalisation in the processes of capitalist production and reproduction. For instance, the new capabilities presented by "machine intelligence" to deduce behaviour enabled targeted advertising (Zuboff 2019, 77-78), which revolutionises the process of realisation of surplus value. These insights could also be embedded in an analysis of the system of needs in capitalism and how the digitalisation process contributes to the distortion of this system for the purposes of realisation of surplus value. Last but not least, they could be used for a comprehensive analysis of the use of data in behaviour influence or modification towards systemic political solutions or in the process of de-politicisation, which is essential for the reproduction of capitalist social relations.

Nevertheless, Zuboff's analysis itself does not go very far with these insights precisely because her premise and, consequently, her conclusions are one-sided.

\subsection{A Break with Capitalism's Past...}

Let us take a closer look at Zuboff's theoretical premises, both of which stem from her claim that surveillance capitalism constitutes a break with capitalism's past. To begin with, there is an idealist foundation in her theoretical premise. This is manifest when she explicitly claims that "surveillance capitalism was invented by a specific group of human beings in a specific time and place" (Zuboff 2019, 85). She does this to argue that it is "not an inherent result of digital technology", nor "a necessary expression of information capitalism" (Zuboff 2019, 85). The implication of this claim is that "surveillance capitalism" results neither from the development of productive forces ("digital technology") nor from the development of relations of production ("information capitalism"), let alone from their contradiction; it rather results from the arbitrary, entirely contingent actions of a specific group of people in a particular time and place. This claim may be in line with postmodern approaches to historical development but it hardly contributes anything of value in the analysis of contemporary capitalist contradictions.

Arguably, the developments captured by Zuboff's concept of "surveillance capitalism" are the inherent result of the contradiction between forces and relations of production and how the latter determine the way in which the former are employed (even though there is always mutual determination). As we saw in Engels's contribution to the critique of political economy, the development of productive forces - including technological development - is never class neutral but always takes place in the context of specific relations of production that determine the aim, motivations, prioritisations and level of development of these forces. Instead of developing this further, Zuboff exhausts her analysis in superficial analogies that betray a lack of understanding of the logic of capitalism. Google's "revolution" of the twenty-first century is compared to Ford's "revolution" of the twentieth century. As Ford's inventions revolutionised production, "Google's inventions revolutionised extraction and established sur- 
veillance capitalism's first economic imperative: the extraction imperative" (Zuboff 2019, 87).

Additionally, Zuboff claims that surveillance capitalism inaugurates a new market form which "declares that serving the genuine needs of people is less lucrative, and therefore less important, than selling predictions of their behaviour" (Zuboff 2019, 93). In that way surveillance capitalism is opposed to a benevolent type of capitalism which supposedly serves the needs of society. Both of these claims are rather superficial. Capitalism as a whole is characterised by the logic and imperative of a specific kind of extraction, i.e. the extraction of surplus value which is the raison d'être of this mode of production, its existential precondition. As we shall see in the next section, is not "extraction"-in-the-abstract that is revolutionised by "surveillance capitalism" but, arguably, the extraction of surplus value from the user-consumer, as well as the processes of circulation and realisation of surplus value. After all, the thirst for profit determines the growth of data analysis and selling of prediction products to companies looking to actualise surplus value.

More importantly, the second claim is based on a misconception of the role of needs in capitalism. Zuboff expresses the view that needs-satisfaction is the causal root for healthy capitalist development and that "new market forms are most productive when they are shaped by an allegiance to the actual demands and mentalities of people" (Zuboff 2019, 32). Capitalism in general, she claims, "evolves in response to the needs of people in a time and place" (Zuboff 2019,31). This again implies a distinction between a benign capitalism, represented by the Fordist model, and surveillance capitalism as its parasitic distortion. This distinction is also echoed in Zuboff's classification of big digital monopolies according to whether or not their operations respond to individual needs, or, as she puts it, whether they reunite supply and demand (Zuboff 2019, 30). In this context, Apple does not perform surveillance capitalism because it merely "collects behavioural data with permission and solely as a means to product or service improvement", whereas Amazon "appears to be migrating toward surveillance capitalism, with its new emphasis on 'personalized' services and third-party revenues" (Zuboff 2019, 22-23). In this way Apple represents a "new rational capitalism", which is part of a commercial reformation that shifts the focus of consumption from the mass to the individual (Zuboff 2019, 30).

Zuboff's superficial analysis allows her to side with one monopoly against another, completely disregarding the issue of exploitation, based on the argument that this new rational capitalism will better attune production to individual needs. However, the existence of a benign capitalism where production is focused on needs-satisfaction is refuted by the Marxian and Marxist analyses of capitalist contradictions. The needs of the people are not the causal root for capitalist development; profit is. In capitalist society, the satisfaction of social needs is not an end in itself. On the contrary, the end of production is the valorisation of capital, whereas the satisfaction of social needs (on the market) is only a means towards this end (Heller 2018, 49). As Marx puts it: "a certain rate of profit [...] determines the expansion or contraction of production, instead of the proportion between production and social needs, the needs of socially developed human beings" (Marx 1894, 367).

The opposition between a benign capitalism and a distorted capitalism, whose manifestation surveillance capitalism is, echoes the neo-Keynesian distinction between neoliberalism and welfare capitalism. The above points suggest that surveillance capitalism continues along the path of neoliberalism and exacerbates its worse tendencies. Indeed, Zuboff argues that surveillance capitalism departs from the history of market capitalism as it abandons the "reciprocities with people and society" and 
imposes a "totalising collectivist vision of life in the hive" (Zuboff 2019, 21). This constitutes a break with capitalism's past, where firms relied "on people as employees and customers" and where "price increases had to be balanced with wage increases": "surveillance capitalists no longer rely on people as consumers" (Zuboff 2019, 499). The "coup from above" that surveillance capitalism signifies is the destruction of the centuries' old social contract between capitalism and its communities.

\section{2. ...or Direct Result of Capitalist Contradictions?}

Two points need to be raised regarding Zuboff's idyllic representation of capitalism's past that follow from Engels's insights on the labour theory of value. First, her representation of the "social contract" between capitalism and its communities is not a very accurate depiction of capitalist reality. The relationship between capital and employees is not one of reciprocity but rather one mediated by the extraction of surplus value. The wage is neither a gift nor a gesture of social awareness by the capitalist to their employees. The wage represents the value of labour power, which is determined by the value of means of subsistence necessary to reproduce this labour power. The capitalist has an interest to pay a wage that corresponds to the bare necessities which will ensure the worker appears every day for work. It is only the collective struggle of the workers, based on the exact opposite interest, which can pressure capitalists into concessions and "reciprocities" to the working class.

Moreover, it has to be noted that the reproduction of capitalism does not primarily rely on consumers' demand, but rather on conditions of profitability which enable the expanded reproduction of capital. Capital sustains itself only on the basis of the iron law of accumulation. Capital needs to valorise itself and can only do this through the appropriation of more and more surplus value, through the exploitation of the living labour it employs. As long as conditions of profitability are ensured, its reproduction is also ensured; which is why the tendency of the rate of profit to fall poses the main barrier through which capital constantly tries to escape. On the contrary, consumers' demand may not be the determining factor for a capitalist crisis (as Keynesian approaches would argue), but it is an important factor that affects the development of such a crisis. Last but not least, it is important to note that surveillance capitalists may indeed "no longer rely on people as consumers", but they sell their products to companies that do. Digitalisation has revolutionised the process of circulation and realisation of surplus value, making it more efficient for capital. But in no way has this altered the main parameters of capitalist production, contrary to Zuboff's argument.

Zuboff's nostalgia for an idyllic capitalist past determines the prescriptive part of her exposition: capitalism, which is never meant to be eaten raw, is to be "cooked" with democracy and regulation. Hence, her insistence on the need for new laws: regulation of the raw aspects of surveillance capitalism, similar to the regulation of the "antisocial and antidemocratic practices of raw industrial capitalism" is the solution (Zuboff 2019, 343). A new wave of "progressive" legislation, reminiscent of the welfare reforms that once righted "the balance of power between employers and workers" is necessary to reject "the fundamental legitimacy of surveillance capitalism's declarations and interrupt its most basic operations, including the illegitimate rendition of human experience as behavioural data" (Zuboff 2019, 343).

It is evident from the above that Zuboff's prescription follows directly from the premises of her analysis. Her diagnosis that surveillance capitalism constitutes a break with capitalism's past leads to the conclusion that we can return to this idyllic past through reform. Thus, her prescription consists of a systemic proposal to mitigate the effects of what she calls "surveillance capitalism", rather than eradicate the 
problem by radically changing the orientation and use of the relevant technologies. She argues for a return to a capitalism that tends to people's needs by reuniting supply and demand. Echoing this fundamental concern of neo-Keynesians Zuboff betrays a theoretical misconception of capitalist contradictions and the role of technological development in their unravelling.

We argue instead that surveillance capitalism is the direct result of developing contradictions inherent in the capitalist mode of production. Phenomena like data mining and targeted advertising revolutionise the processes of circulation and realisation of surplus value; the radical increase in the velocity of the former leads to a radical reduction of the turnover time and, thus, operates as a factor that counters the LFRP, i.e. the ultimate barrier of the capitalist mode of production. As a direct result of capitalist contradictions, surveillance capitalism cannot be reformed; productive forces cannot be put to different use or employed to satisfy social needs, unless embedded in a different system of productive forces and social relations.

\section{Marxist Critiques of Digital Surveillance}

Let us develop these points further by looking at alternative views on digital surveillance in order to show how they contribute to more comprehensive analyses of phenomena and processes described as "surveillance capitalism" by Zuboff, as well as how Engels's analysis has influenced and can further influence these approaches. These contributions focus on the economic implications of internet surveillance (Fuchs et al. 2012, Andrejevic 2013), as well as several other aspects of the process of digitalisation (Fuchs and Sandoval 2014; Fuchs and Mosco 2016) from a Marxist perspective. Central to these approaches is the focus on the totality of capitalist social relations, while ascribing primacy to the relations of production and the issue of exploitation. The relations of distribution and circulation are assessed in their unity with the relations of production, in accord with the methodological principles developed by Marx and Engels's critique of the capitalist economy (Marx 1857-1858, 83111).

Based on the main principles of the labour theory of value, these analyses conclude that surveillance is intrinsic to the capitalist mode of production and the process of capital accumulation. Marx distinguishes two spheres of capital accumulation: the circulation sphere and the sphere of production (Fuchs 2012, 39). In the circulation sphere, capital first appears in the form of money and transforms itself into commodities: the capitalist buys the commodities of labour power and means of production (Marx 1885, 116). In the sphere of production, new goods are produced embodying the value of labour power (in the form of variable capital) and the value of the means of production (in the form of constant capital).

Surveillance is a central means to various ends in both spheres of the process of capital accumulation. Capital employs different methods of surveillance in the processes of production and circulation in order to minimise the risk of incurring losses and maximise the opportunities for making profits (Fuchs 2012, 43). For instance in the sphere of production, surveillance targets the workers at the workplace through managers, supervisors, workplace surveillance technologies, databases, participatory management, identification systems, surveillance of employees' Internet activities, etc. (Fuchs 2012, 45). Marx himself had identified the significance of surveillance practices "from the moment that the labour under capital's control becomes cooperative" (Marx 1867, 449). According to Marx, the supervision of labour in the production process is "purely despotic": the industrial army of the workers "under the command of a capitalist requires, like a real army, officers (managers) and N.C.O.s 
(foremen, overseers), who command during the labour process in the name of capital" (Marx 1867, 450).

Similarly, in the sphere of circulation the target of surveillance can be the potential workforce, i.e. the applicants for employment, which a corporation scrutinises through access to criminal records, health databases, bank data, employment histories, information search on the Internet, etc. (Fuchs 2012, 45). More relevant to our discussion, surveillance in the sphere of circulation takes the form of consumer surveillance, whereby "consumption interests and processes are systematically observed and analyzed in order to guarantee the selling of as much commodities as possible and the realization of profit" (Fuchs 2012, 45). This used to take place through marketing and consumer research, but it now predominantly takes place through digital surveillance mechanisms, i.e. cookies, targeted advertising mechanisms, spyware, profiling of Internet usage behaviour, data mining, clickstream monitoring, etc. (Fuchs 2012, 45).

The primacy ascribed by this Marxist approach to the relations of production has led to the appearance of literature which explores the issue of exploitation in the process of surveillance and data collection. A critique of digital surveillance from this angle goes beyond the one-sidedness of the critique of privacy invasion. It is argued that the latter "does not do justice to the productive character of consumer surveillance", whereby consumers are asked to pay for surplus extracted from their own work (Andrejevic 2012, 73). Under this prism, the crucial question is if the users of commercial social media are generating value and whether they are exploited (Fuchs $2016,45)$. This question leads to an exploration of several other questions: Is platform usage creating value (i.e. time objectified in a product sold as a commodity)? What activity counts as labour? Is the sole criterion value creation? Even if such activity is contributing to value creation, is this activity productive labour? Is there a relation of exploitation? Is there coercion and alienation and where are they located?

The answers to these questions are far from settled, but a compelling attempt to answer them can be found in Christian Fuchs's elaboration that is based on a conception of productive labour as labour of the collective worker. This concept is set out by Marx in Capital: "In order to work productively, it is no longer necessary for the individual himself to put his hand to the object; it is sufficient for him to be an organ of the collective labourer, and to perform any one of its subordinate functions" (Marx $1867,643-644)$. Fuchs goes on to define what he calls the symbolic value of a commodity, i.e. a cultural component that is created by cultural labour, which "establishes a link and mediates between use-value and exchange-value", by helping convince potential buyers that a good or service will enhance their lives thereby contributing to the completion of the exchange, in which consumers obtain use-values and capitalists realise their profit (Fuchs 2016, 51). Fuchs argues that the labour-time invested in the creation of this symbolic dimension (through departments of public relations and advertising) is calculated into the price of commodities

Turning to the commodities produced by social media corporations, he argues that they consist of a portion/space of a user's screen/profile that is filled with ad clients' commodity ideologies, highly targeted to user activities and interests (Fuchs $2016,53)$. For the creation of this commodity, the users' constant online activity is necessary "for running the targeting algorithms and for generating viewing possibilities and attention for ads": "the ad space can therefore only exist based on user activities that are the labour that create the social media prosumer commodity" (Fuchs $2016,53)$. Once he concludes that platform usage is labour, Fuchs goes on to argue that it is also productive labour by providing an analogy with transportation labour. In 
the same way that the labour in the transportation industry adds value to the products transported, "partly through the value carried over from the means of transport, partly through the value added by the work of transport" (Marx 1885, 226-227), advertising transport workers transfer value on the product by organising "a communication space that allows advertisers to communicate their use-value promises to potential customers" (Fuchs 2016, 54). Therefore, platform users create value, as their labour is objectified in these commodities, and usage of these platforms is productive labour. Users are productive workers whose activities are necessary for "transporting" use-value promises from companies to potential customers: in the twenty first century transportation labour is communication labour (Fuchs 2016, 54).

This is arguably a compelling application of the labour theory of value, developed by Marx and Engels, to the analysis of contemporary processes and phenomena. It is certainly a more comprehensive and many-sided account of the processes and phenomena captured by the term "surveillance capitalism" than the one offered by Zuboff, because it places emphasis on capitalist relations of production and circulation that Zuboff fails to address - from the standpoint of surplus-value realisation and profitability. It therefore assesses the growth of social media platforms as a response to capitalist contradictions that is in line with capital's thirst for profit and permanent need for expanded reproduction and not as an aberration of a system that normally corresponds to social needs.

With regards to the process of circulation, the Marxist approach to digital capitalism builds on the aforementioned contradiction, identified by Engels, between "the enormous expansive force of industry" and the resistance offered "by consumption, by sales, by the markets for the products of modern industry" (Engels 1880, 315). It is argued that the advancement of information and communication technologies corresponds to the need to overcome the barrier of consumption. Digital platforms and new media are crucial for the articulation of the consumption capacity of individuals. The new digital information and communication technologies reproduce a social being whose capacities develop in line with the requirements of circulation (Manzerolle and Kjøsen 2016, 169). For instance, through the advancement of such technologies free time is mobilised to serve the circulatory needs of capital: "the colonisation of everyday life by digital and networked devices has opened up new pores, cracks, and crevices of daily life into possible moments of communicative utility in service of capital's logic of acceleration" (Manzerolle and Kjøsen 2016, 169).

The above is directly relevant to the contradiction between production and consumption, however, the issue of profitability is not explored. This is where Engels's discussion on capital's turnover time is crucial. Christian Fuchs hints at this when he refers to turnover time as the sum of the circulation time and production time (Fuchs 2016, 40), but it is Manzerolle and Kjøsen who come closer when they discuss the role of new media platforms in radically increasing the velocity of capital and consequently decreasing the time of circulation: "to accelerate [...] capital must develop or adopt media that allows it to bind space and time, and thereby progressively overcome the barriers capital posits to its functioning" (Manzerolle and Kjøsen 2016, 158). This increase of velocity is approached from the perspective of surplus value creation: because the sum and mass of surplus value created within a period is negatively determined by the velocity of capital, the faster capital moves through the sphere of circulation, the more surplus value will be created and validated (Manzerolle and Kjøsen 2016, 159).

However, as we saw in the first section, Engels showed that any factor which affects the production of surplus value by influencing the turnover time of capital also 
affects the rate of profit. Reducing the time of circulation equals reduction of turnover time, equals increase of the rate of profit. As Engels put it, "the chief means of "cutting circulation time has been improved communications" (Marx 1894, 164). This is what directly links the process of digitalisation and phenomena described as surveillance capitalism to the LFRP. The effect of the reduction of circulation time, enabled by data capture and data mining as well as targeted advertising, on the rate of profit is key to explain the growth of new media platforms, because it points to the central contradiction in capitalism, i.e. the tendency of the rate of profit to fall.

This ultimate barrier to the capitalist mode of production is countered by many factors, some of which are mentioned by Marx and Engels in Volume three of Capital. Recently it was argued that the exponential growth of the banking and finance sector should be regarded as a further (temporary) countertendency to the LFRP (Passarella and Baron 2015). This sector enables industrial firms to increase the speed of turnover of their capital, therefore crucially affecting their profitability. I argue that the above practices (e.g. data mining, targeted ads, etc.), captured under the terms "surveillance capitalism" or "digital capitalism" can also be considered among the factors that counter the LFRP. Consequently, not only the process of "financialisation" of advanced economies but also the process of "digitalisation" of the last decades can be considered as the "humpback bridge" that the capitalist class has eventually gone through to sustain the profitability of capital (Passarella and Baron 2015).

\section{Conclusion}

This paper tentatively but explicitly articulated the hypothesis that Engels's elaboration on the effect of capital's turnover time on profitability provides an analytical framework within which the growth of digital media platforms and phenomena like targeted advertising can be explained. It follows that the exponential growth of digital platforms can be explained as a direct result of the development of capitalist contradictions, especially the contradiction between productive forces and relations of production as expressed in the LFRP. On this basis, Shoshana Zuboff's claim that surveillance capitalism constitutes a radical break with capitalism's past was countered.

Marxist contributions to the critique of digital surveillance have already approached this phenomenon in a many-sided manner. Rather than focusing solely on the issues of privacy or wealth, they have explored whether the growth of digital surveillance can be attributed to developments in productive relations, relations of circulation from the standpoint consumption, i.e. surplus value realisation, as well as relations of circulation from the standpoint of surplus value production. This paper built upon these contributions and suggested approaching this phenomenon with a focus on the process of circulation from the standpoint of profitability. Ultimately, this paper seeks to invite further research on this issue, as well as stress that Engels's work remains absolutely relevant for the analysis of the contradictions of contemporary capitalist societies.

\section{References}

Althusser, Louis. 2006. For Marx. London: Verso.

Anderson, Kevin. 1995. Lenin, Hegel, and Western Marxism: A Critical Study. Chicago: University of Illinois Press.

Andrejevic, Mark. 2013. Infoglut: How Too Much Information Is Changing the Way We Think and Know. London: Routledge. 
Andrejevic, Mark. 2012. Exploitation in the Data Mine. In Internet and Surveillance: The Challenges of Web 2.0 and Social Media, edited by Christian Fuchs, Kees Boersma, Anders Albrechtslund, and Marisol Sandoval. 71-88. London: Routledge.

Carchedi, Guglielmo and Michael Roberts. eds. 2018. World in Crisis: A Global Analysis of Marx's Law of Profitability. London: Haymarket Books.

Carver, Terrell. 1984. Marxism as Method. In After Marx, edited by Terrence Ball and James Farr. 261-278. Cambridge: Cambridge University Press.

Engels, Friedrich. 1880. Socialism: Utopian and Scientific. In Marx \& Engels Collected Works (MECW) Volume 24, 281-325. London: Lawrence \& Wishart.

Engels, Friedrich. 1878. Anti-Dühring. Herr Eugen Dühring's Revolution in Science. In Marx \& Engels Collected Works (MECW) Volume 25, 5-309. London: Lawrence \& Wishart.

Foster, John Bellamy. 2017. The Return of Engels. Monthly Review 68 (10).

Fuchs, Christian. 2016. Towards Marxian Internet Studdies. In Marx in the Age of Digital Capitalism, edited by Christian Fuchs and Vincent Mosco. 22-67. Leiden: Brill.

Fuchs, Christian. 2012. Critique of the Political Economy of Web 2.0 Surveillance. In Internet and Surveillance: The Challenges of Web 2.0 and Social Media. edited by Christian Fuchs, Kees Boersma, Anders Albrechtslund and Marisol Sandoval. 31-70. London: Routledge.

Fuchs, Christian, Kees Boersma, Anders Albrechtslund and Marisol Sandoval. eds. 2012. Internet and Surveillance: The Challenges of Web 2.0 and Social Media. London: Routledge.

Fuchs, Christian and Vincent Mosco. eds. 2016. Marx in the Age of Digital Capitalism. Leiden: Brill.

Fuchs, Christian and Marisol Sandoval. eds. 2014. Critique, Social Media and the Information Society. London: Routledge.

Gould, Stephen Jay. 1977. Ever Since Darwin. New York: Norton.

Heinrich, Michael. 2016. "Capital" after MEGA: Discontinuities, Interruptions and New Beginning. Crisis and Critique 3 (3): 93-138.

Heinrich, Michael. 2013. Crisis Theory, the Law of the Tendency of the Profit Rate to Fall, and Marx's Studies in the 1870s. Monthly Review 64 (11).

Heinrich, Michael. 1996/97. Engels's Edition of the Third Volume of Capital and Marx's Original Manuscript. Science and Society 60 (4): 452-466.

Heller, Agnes. 2018. The Theory of Need in Marx. London: Verso.

llyenkov, Evald. 2020. Intelligent Materialism: Essays on Hegel and Dialectics. Chicago: Haymarket Books.

Lewontin, Richard and Richard Levins. 1985. The Dialectical Biologist. Cambridge, MA: Harvard University Press.

Losurdo, Domenico. 2004. Hegel and the Freedom of the Moderns. Durham, NC: Duke University Press.

Manzerolle, Vincent and Atle Mikkola Kjøsen. 2016. Digital Media and Capital's Logic of Acceleration. In Marx in the Age of Digital Capitalism, edited by Christian Fuchs and Vincent Mosco. 151-179. Leiden: Brill.

Marx, Karl. 1894. Capital. Volume III. London: Penguin.

Marx, Karl. 1885. Capital. Volume II. London: Penguin.

Marx, Karl. 1868. Letter to Engels, April 30. In Marx \& Engels Collected Works (MECW) Volume 43, 20-25. London: Lawrence \& Wishart.

Marx, Karl. 1867. Capital. Volume I. London: Penguin.

Marx, Karl. 1857/1858. Grundrisse: Foundations of the Critique of Political Economy. London: Penguin.

Mavroudeas, Stavros. 2020. Friedrich Engels and his Contribution to Marxism. Human Geography 13 (2): 187-190.

McLellan, David. 1977. Friedrich Engels. Harmondsworth: Penguin. 
Moseley, Fred. 2018. The Development of Marx's Theory of the Falling Rate of Profit in the. In Marx's Capital: An Unfinishable Project?, edited by Marcel Van der Linden and Gerald Hubmann. 95-143. Leiden: Brill.

Moseley, Fred. 2015. Introduction. In Marx's Economic Manuscript of 1864-1865. edited by Fred Moseley. 1-44. Leiden: Brill.

Passarella, Marco Veronese and Hervé Baron. 2015. Capital's Humpback Bridge: "Financialisation" and the Rate of Turnover in Marx's Economic Theory. Cambridge Journal of Economics 39 (5): 1415-1441.

Roberts, Michael. 2015. The Marxist Theory of Economic Crises in Capitalism - Part One. Retrieved from https://thenextrecession.wordpress.com/2015/12/27/the-marxist-theory-ofeconomic-crises-in-capitalism-part-one/

Roberts, Michael. 2013. Michael Heinrich, Marx's Law and Crisis Theory. Retrieved from https://thenextrecession.wordpress.com/2013/05/19/michael-heinrich-marxs-law-andcrisis-theoryl

Roth, Regina and Fred Moseley. 2002. Guest Editors' Introduction. Journal of Political Economy 32 (1): 3-13.

Seigel, Jerrold. 1978. Marx's Fate: The Shape of a Life. Princeton: Princeton University Press.

Waitzkin, Howard. 1983. The Second Sickness. New York: Free Press.

Zuboff, Shoshana. 2019. The Age of Surveillance Capitalism: the Fight for a Human Future and the New Frontier of Power. London: Profile Books.

\section{About the Author}

Dimitrios Kivotidis

Dr. Dimitrios Kivotidis is Lecturer in Law at the University of East London. His research focuses on legal and political theory, constitutional law and human rights, as well as on the relationship between law and political economy. He is a member of the editorial collective of Legal Form, a forum for Marxist analyses of law. 


\title{
The Digital Economy of the Sourdough: Housewifisation in the Time of COVID-19
}

\author{
Julianna Faludi* and Michelle Crosby** \\ *Corvinus University of Budapest, Budapest, Hungary, faludisociology@gmail.com, \\ www.juliannafaludi.com
}

${ }^{* *}$ Corvinus University of Budapest, Budapest, Hungary, michelleo.crosby@gmail.com

\begin{abstract}
The most brilliant part of re-visiting Engels, were the stark reminders, sometimes paragraph by paragraph, of key, essential truths that remain valid today in 2020 regarding new (perhaps old, but now more visible) forms of housewifisation, unto which SARS-CoV2 has shown a mirror to every person who has ever concerned themselves with gender in-balance, lay person to expert. This paper is about justifying those claims as essential truths by drawing modern parallels and also intends to generate a discussion on the form of the family and societal organisation which would support human flourishing, regardless of gender by formulating a new, post-COVID gender order.
\end{abstract}

Keywords: housewifisation, digital economy, exploitation, Engels, SARS-CoV2

Acknowledgement: The authors acknowledge the reviewers of the first drafts of this paper affiliated with the Karl Polányi Research Institute, and the editor of the special edition of tripleC.

\section{Introduction}

This paper takes under scrutiny the new forms of exploitation and housewifisation in digital capitalism in the context of the pandemic-lockdowns. The home office has overturned what we know and think about digital work, as the workplace has been replaced to homes, along with several functions, like schooling and social services being provided beforehand by the state and market structures. It is not the Internet economy that exploits people related to the restrictions, it went further, people take on the burden of the state, the costs of schooling etc., while the state enforces and extends its surveillance to monitor the communication and the location of people.

From a theoretical perspective, this has implications on at least two levels: we need to reconsider where we place the role of the state, the role of the exchange value of goods, and the role of money in this economic circuit as forms of alienation. Furthermore, we need to understand the role of digital labour and the shifting societal division of labour. Public spending cuts have been visible in the budgeting of policy programmes, but domestic work has been always just estimated due to a lack of systematic data being gathered on the national level. The outsourcing of schooling and social services along with the home office has created a new trend of housewifisation. Mies $(1982 ; 1986)$ found that homeworkers were superexploited, denied social security, and often poor. Her study of lace makers in India revealed that homeworkers who were producing lace in a putting-out system were paid low wages based on the ideology of the housewife, which legitimised the superexploitation of women at home with wages below the subsistence level (Mies 1982). According to Mies's (1986) theory the rise of capitalism under patriarchy, capital sees women, nature, and the colonies as standing 
outside of civilised society and therefore treats them as cheap sources of value. Mies $(1986,112-116)$ argues that in the $19^{\text {th }}$ and $20^{\text {th }}$ centuries the construction of the housewife went through two main stages: first the creation of the women of the accumulating classes who consume luxury goods and as bourgeois housewives are agents of consumption. And second, proletarian women who became the "colony" of white men . They labour in the nuclear family. Only the class of the wealthy could afford to have a family. The bourgeoisie declared "family a private territory in contrast to the 'public' sphere of economic and political activity" (Mies 1986, 104). Prügl $(1996,115)$ a decade later in an empirical work explored different socio-economic contexts from the perspective of colonisation and confirms that women defined as housewives "have become the optimal flexible labour force".

Today, the housewife is represented with the image of the sourdough-bread baking woman. The load of unpaid work and waged labour has grown, and advances the selfexploitation of the "housewife".

Since contemporary societies have love-driven, and interest-driven marriages in their diverse forms, we need to look at the institution of marriage and other forms of cohabitation from the perspective of: 1) economic organisation as a driving force behind these institutions; and 2) institutional evolution itself. Institutional evolution implies that cohabitation exists in society in one given time period as a heritage of previous times, when given forms have emerged and established themselves, as well as new forms that emerge organically in the given era, but are being perceived as innovations, thus not being wide-spread and are being tied to some social groups within the society.

\section{Digital Pairing}

Engels in his work on The Origin of the Family, Private Property and the State (1891a) tied the place of sexuality in the society to two essential drivers. The changing environment, such as the extinction of the huge mammals due to over-hunting, created disruptions within the communities. Hunting communities of people had to be segmented to smaller groups in order to survive. Male-dominance emerged by males taking control over organising symbolic rituals around the resource-provision from females. Thus, changing conditions pushed people to economic re-organisation, and to re-arrange their customs that affected the modes of reproduction. New instruments of production had to be created for survival, and this technological advancement was tied to the reshuffling of social relations of humans. Biological entities that went through a natural evolution, had been pushed to civilising themselves into a culture of private property and domesticated sex with one partner - forming a household, also known as paired marriage.

In the longer term, this shift commodified the marital status. Exchange of the "female" in return for economic benefits, added exchange value - the bride price - to females being bought from their families. The commodification of women for creating heritage and wealth in the long run, and rendering marriage itself into the market domain - went a long way, and was present during the processes of industrialisation and the birth of capitalism. The pre-condition for class societies to emerge was the creation of forms of oppression, where monogamy - one-sided as being expected mostly from women - was a tool to break community surveillance and (sisterhood) solidarity to give way to competition and appropriation of wealth and resources. The institution of private property is at the core of dissolving communities - a law of Marxist logic that is also valid for intimacy, and the "privatising" process of human sexuality, and privatisation of intimacy has creeped along during modernisation. 
For example, forms of cohabitation might be tied to social class, but in contemporary societies, the liberalisation of the legitimised forms goes along with the conservative de-legitimation process of the variations of cohabitation. Marriage and diversity of sexuality have become a commodity deployed by political elites enforcing agendas within the socio-political domain. This can be seen as a political enforcement rather than an economic one, given that the aim is not purposefully creating efficient economic organising - think of what the household as an economic unit meant for the market and the state in the mid-and late 20th century. The aim of political commodification of forms of cohabitation and individual sexuality is the creation of a stable electoral base in the short and mid-term, and the creation of content for feeding the masses. In this regard it is no less than the creation of other thematic content within the political social-mediatised communication. Sexuality and cohabitation have left the private domain. The life of people living together could remain in the private zone only for a shorter period of time, and mostly in urbanised and economically prospering geographical areas. This does not imply that these spheres have not been controlled domains before, but the trends of loosening the social norms around sexuality and then pulling them back just to create a social discourse to feed the content-driven public is a phenomenon of the $21^{\text {st }}$ century. Sexuality - such as sexual preferences of the individual or the structure of families and the role of women - are a political commodity that thematises public discourse on sexuality in the media and on social media in the context of digital capitalism and social media society.

Another example is the notion of "content is king" - attributed to Bill Gates in 1996 (published on the website of Microsoft ${ }^{1}$ ), described precisely in the advent of today's era that the Internet belonging to communities and people for free-gazing would become soon a marketplace for commodities such as content. By content Bill Gates meant entertainment that can reach out to a vast audience with zero marginal costs and can be duplicated as much as one likes. News magazines would be structured around interactivity - an increased number of clicks and chat discussions - and defined by content in a way that print would never be able to.

Sexuality has come across multiple commodification processes, where the final stage is the marketplace for partners, the culture of swiping images of potential dates, being referred to as swiping culture. This can be linked to various motivations, such as finding a long-term partner, but mostly it serves the "hookup culture" of casual dating that is organised with the help of platforms and apps such as Tinder. Hookup culture has been around since the 1920s, but social media platforms accelerate the encounters individuals might have within a limited time span, by serving a present need of individuals - young women and men - not looking for a stable relationship due to plans of studying, working, etc.

In digital capitalism, time is commodified by the attention-deficit economy. Visibility is turned into an added value of the persona - the public social media image of the individual. Dating platforms have converted the individuals into "hunters" deploying the benefits of swiping and hooking up with a broad number of available targets, while these hunters themselves are not recognising the commodification of their own sexualised image. Capitalist platforms such as Tinder, Bumble, or Hinge are ripping the economic benefits of this exchange.

Distancing and the severe border-lockdowns across countries, regions and districts has separated some couples and locked other couples unexpectedly in one space.

${ }^{1}$ https://medium.com/@HeathEvans/content-is-king-essay-by-bill-gates-1996-df74552f80d9 
The COVID-economy on the one hand enhanced porn-consumption ${ }^{2}$ that was fuelled by the availability of free-content provided by some of the platforms, like Pornhub (Mestre-Bach et al. 2020), and changed the dating habits and intimate relations on the other hand (Dewitte et al. 2020). According to Seidman, the boss of the largest dating social media platform Tinder $^{3}$, lockdown has brought an increase in swipes with a "dramatic shift in behaviour metrics", but falling subscriptions to the premium services of the app. Virtual dating became popular on platforms like eHarmony, OKCupid and Match supporting video dating options, pushing Tinder to expand its services for organising dating events online rather than serving offline dating matches. Dating apps in sum were reported growing and becoming more virtual ${ }^{4}$ as a consequence, after the initial drop in subscribers but a rise in online activity. The shifts in services, such as the passport function on Tinder, and user behaviour also suggest that virtual meaningful connections became important and more location agnostic compared to the previously experienced fast matching. The longer-term effects of these changes are yet to be explored, and it is not clear how virtual meaningful dating will shape behaviour in the future, and if it has any impact on the traditional or now-known institutions of cohabitation and the geography of matching. What can be seen is that the conditions of physical distance, insecurity and alienation have brought together some couples, yet further alienated others.

\section{Digitised Monogamous Pairing Households}

The economic organisation as a driving force behind the creation of the households was and is a persistent model, with some degree of shift in the centrality of the household to the larger economy of firms. In primitive communism however, human reproduction was driven by sexuality, and in Engels' view allowed for parity of the sexes. He supports Bachofen's assertion that the shift from mother-right to father-right downgraded status of women: "women, who, as mothers, were the only definitely ascertainable parents of the younger generation, were treated with a high degree of consideration and respect, which, according to Bachofen's conception, was enhanced to the complete rule of women (gynaecocracy)" (Engels 1891b, 205). Sisterhood and solidarity among women, and among men would create large families, and save individuals from domestic or sexual violence. Social norms were under close scrutiny within the community, especially when the institution of abolishing incest emerged. Power did not break societies into classes yet, as the main function of the community was not accumulation of wealth but rather human reproduction. Contemporary societies that are shaped by digital capitalism in the social media age do not focus on biological human reproduction but on capital accumulation mediated by digital technologies.

Modern families have found themselves locked in their homes in a family structure that turned out to be efficient and dysfunctional at the same time in so many ways. Stories about the obstacles in meeting extramarital dates, reports about increased

${ }^{2}$ https://www.economist.com/international/2020/05/10/pornography-is-booming-during-thecovid-19-lockdowns

3 https://www.bbc.com/news/business-52743454

4 https://www.emarketer.com/content/love-time-of-coronavirus-dating-apps-growingbecoming-more-virtual 
home-abuse, and the increased tendency of divorce have drawn attention to the dysfunctions of the persistent structure. UN Women reported ${ }^{5}$ that there was a significant increase at least in $50 \%$ of the countries in reports to the police, health centres, helplines after the outbreak of the COVID-19, in other countries there was a decrease due to the restrictions in mobility. Particularly vulnerable became women with disabilities or those who recovered from COVID-19, and returning migrant women facing exclusion and stigmatisation in the communities. Among the exacerbating factors are the isolation with the abusers, security and money worries, and deserted public spaces.

Engels and Marx viewed the transformation of relationships of genders and the family from the perspective of social transformation and economic organisation. The industrial revolutions tore men from their families, that as a consequence reinforced the gendered division of labour in households. Expanding the view on families in the context of the social changes and the complex economic transit of the COVID-19 economy, relationship patterns are defined by the accelerated digitalisation processes and the collision of the public ad privat -social spaces in the home. Households became central, and families became the sole functional economic unit for filling in the gap imposed by the state (schooling, social services, healthcare) efficiently only in cases where a more equalising division of labour has occurred in the household. A report from Turkey ${ }^{6}$ suggests that men's unpaid work time went up nearly five-fold during the lockdown, especially among those who switched to the home office. The increased demand for household production and caring labour has brought a necessity of participation of most family members. Yet women were still performing four times more unpaid work than men.

A survey ${ }^{7}$ (Weissbourd et al. 2020) found that fathers felt closer to their children during the lockdown, across race and class in the US. An analysis conducted in the UK conducted in March and April 2020 revealed that fathers reported to do $58 \%$ more childcare work than normally (ONS 2020). The report also reveals that fathers would need more flexible working arrangement for participating more in childcare, and that they feel their jobs would be more threatened than women's when asking for remote working solutions at their workplaces.

Shifting towards the home as the central economic system generated increased demand for housework on women as there was a need to create a space for childcare provided by men. Thus, men were more prone to take over childcare time from women than performing housework. Still, the increase of time spent by men on childcare is a trend to consider when thinking about the new family structure. Yet, we argue that these processes may create a deepening mediatised "housewifisation" since "old institutions" still prevail. Mies (1986) sees housewifisation as the devaluation of women's unpaid and underpaid work, as an underlying accumulation model of the capitalist world economy.

${ }^{5}$ Impact of Covid-19 on Violence Against Women and Girls and Service Provision. UN Women Rapid Assessment and Findings. https://www.unwomen.org/-/media/headquarters/attachments/sections/library/publications/2020/impact-of-covid-19-on-violence-againstwomen-and-girls-and-service-provision-en.pdf?la=en\&vs $=0$

${ }^{6}$ https://www.tr.undp.org/content/turkey/en/home/library/corporatereports/COVID-gender-survey-report.html

${ }^{7}$ https://static1.squarespace.com/static/5b7c56e255b02c683659fe43/t/5eeceba88f50eb1981 0153d4/1592585165850/Report+How+the+Pandemic+is+Strengthening+Fathers+Relationships+with+Their+Children+FINAL.pdf 


\section{4. "Old Institutions" in Modern Monogamous Pairing}

As an illustration of the persisting old institutions that may prevail in the forms of tradition in society are rituals or customs being followed in the framework of the ceremony in the offline domain. Engels placed the marriage by capture in the evolution of marital relationships at a time when gender-based dominance was about to emerge, but matrilineal households still persisted. He writes, "the abduction of women reveals even here a trace of the transition to monogamy - at least in the form of the pairing marriage" (Engels 1891a, 155). The man who lead the ritual of capturing a woman from the other group - either to avoid incest, or to perform dominance over the others - would have the woman for himself after ceasing her. What is described there is a gang rape, where the males of the "hunting" group would demonstrate their dominance over her body. Engels places this custom in the era which he describes as one where women were leaders and respected within the community. But what is not mentioned is that the respected role of leadership was given to in-group females in power-position.

The tradition of "stealing the bride" or "snatching the bride" or kidnapping the bride in some Eastern-European cultures such as Hungary and in the Caucasus is connected to the above described ritual. Molodikova (2013) found that these traditions are still a social reality. The stories of the brides reveal their oppressed status that defines the course of their lives as being forced into marriage and motherhood instead of pursuing their studies, etc.

Some rituals from the times of the marriage by capture have remained until today just like inheritance that for many is until today almost the only way to accumulate wealth. These are structures that have been persisting since the times of the industrial revolutions (Piketty 2013). In pre-class communal societies oppression and arrangement of people into classes came about as a necessity to adapt and to develop new instruments of production. How to adopt to the new challenges today faced by families, and who are the families that we are talking about is yet a question to understand in the wake of the crises since "old institutions" that emphasise self-protection from the market can still be observed.

Communist households that include multiple generations living in the same house can be found in Hungary and other Central and Eastern European countries. This is known as "ket-generacio" or "two-generation". Multi-generation households in the US are perceived as being traditionally reserved to the poor; most probably persons of colour, especially the working class and immigrants, precisely for their protective benefits. Two-generation homes are sometimes coupled with another protection from the market, the Hungarian "homestead", which includes a rich garden - essentially a fully functioning farm with peach trees, fig trees, grapes, tomatoes, chicken, a turkey, other kinds of fowl and domestic farm animals. During Hungarian State Socialism, families used these self-sustaining homesteads as a mechanism against food insecurity and shortages.

Making bread and yogurt in-house, filling cases with kolbasz and even distilling palinka is in Hungary a symbol of pride and self-sufficiency. It is done on top of the care work that is primarily conducted and coordinated by women. To make each household its own factory, rather to outsource or engage with outside places of exchange, requires full-time workers and traditionally large families. COVID-19 re-legitimised these practices similar to the way a "reserve army"' is justified in war-time contingency plans. 


\section{The COVID-19 Economy, Digital Households and Alienation}

In primitive communism, women had strong bonds to exercise power over non-cooperative males. The family was a place where work was shared among the members of the family, the division of labour was a functional one and inherent to the community. That was the point in human history when oppression among individuals was not yet systemic. Marxism sees the family as one of the fundamental units of capitalism, due to its economic unit role, as well as its reproductive role. Engels writes: "The social institutions under which men of a definite historical epoch and of a definite country live are determined by both kinds of production: by the stage of development of labour, on the one hand, and of the family, on the other" (Engels 1891a, 132).

Instead of the image of women being captured and ravaged by friends of her captor, ripped from her tribe, women's role today is more pleasantly re-framed as superwoman. Superwoman, an icon of power, superiority and strength, is frequently referenced as a symbol of female potential, but most importantly presents society's expectations of paired females. Essentially, there are women who volunteer for self-exploitation, defined as the institutionalised slavery of women in the monogamous paired family. The Superwoman Syndrome is a mythical ideal of women inside monogamous paired marriage. The content of the superwoman ideology is that women perform fantastic feats that are posted on social media. This ideology is the carcass upon which the eating machine, the digital economy, both feasts and gains momentum. Women desire to be seen as heroes, "doing it all". A friend remarked: "I am happy with the shift to digitalisation because then I'll be able to teach and go to conferences when the children are sick".

The digitalised household economy is the combination of home-office, homeschooling, and social media image-construction of the individuals. This imposes new roles: those of the "civilised" world out there: family members become co-workers and the home becomes a co-working space and school. Children and parents become students and teachers. Roles that were outsourced to "society" to be provided mostly by the state. These roles became controlled by the framework regulated by the state/ employer outside regulations, and being outsourced to be enforced within the family. The division of labour in the family is imposed by external structures and enforced by the internal split of roles. Alienation spreads from work to home now that workplaces spread into the digitialised household. Alienation has grown to an unprecedented level. The COVID-19 lockdown advanced alienation in the home. A state-enforced familyorchestration pushed families to take on education, healthcare and social services that had been delegated from state-provision to families. Child-rearing as a process internalised to the nuclear family took on an externalised function of education: distant and digital learning has left families with home-schooling and forced parents to take over the school's role with external requirements that pupils have to comply with.

For the first time since industrialisation, the firm is not the central unit of analysis, but rather society has gone back to its roots, to the household. Presently, paid and unpaid labour lack the spatial divide they have previously enjoyed, making female and male contributions (or the lack thereof) more visible. During COVID-19, women were putting food into the oven for their children's lunch with a computer on top of the toaster and the oven so that the headset cord would stretch sufficiently while bending over during an online meeting or webinar. Children completed their school lessons at the small table in the kitchen. We were teaching the children, making money to buy food and the electricity that powers our homes.

The blurring of private and public spheres of life has been underway for some decades now (Dén-Nagy 2018). Among managers, to be always available over and above 
the paid hours of employment is an expectation and requirement for promotion. Since women of child bearing age perform the majority of unpaid labour, they are not available for these additional hours of unpaid paid labour. In addition, the solution isn't a simple matter of her husband leaning in to the household duties, because he himself is occupied with on-demand labour during non-working hours. While it is tempting to blame institutions for such impositions, we must remember that bias is unconscious, and it is men who control most positions of power in capitalist society so that unpaid paid labour is a mechanism for female oppression that comes on top of wage inequality that women face.

The distancing of individuals from collectives, i.e. individualisation, has also been a generation-defined trend that has been worsening for some time. Communities that gave place to a looser structure of neighbourhoods and atomised families, in the fifties and sixties drove people further from affiliating with politics and turning toward civic organisations and religious groups, as explained by Putnam (2000) in the book Bowling Alone. In the early-fifties Nisbet warned about the central state filling in the role of the community if family, church or locality would not be able to fulfil the desires of humans for community. The desire for community has been challenged by the new form of alienation that has been labelled as social distancing in the context of COVID-19 prevention.

Rituals of people-to-people interaction gave path to newly emergent structures, and digital connection more than before is the key social network of humans. The encounter with people one trusts in less distancing encounters is in the pandemic crisis organised as a looser network of virtual connections. There are many stories circulating about the lengthy virtual talks and meetings bringing people closer under the lockdown, which is supported by the shifts in the social and dating media usage behaviour. Digital means of communication create virtual communities that are less defined by the locality, while locality under lockdown and other restrictions of physical social interaction narrows locality to the home and neighbourhood. Families are in this context especially important for the organisation of belonging. The structure and embeddedness of the contemporary family in society places community in the backstage. Authority remains in the hands of the family and reinforces the role of the state. Virtual communities are dispersed, and not suitable for monitoring and ensuring social norms. The COVID-19 economy of digital capitalism enhances state surveillance of individuals and the alienation within families.

The loss of jobs, the shifting of jobs to the home and the acceleration of shifting exchange onto digital platforms have implications for the societal division of labour. Guest workers from Romania and Bulgaria were flying to Germany and Austria to ensure that agricultural and food processing production would continue and there was not disturbance of food supply on the market. Workers forced to live in crowded spaces and work under conditions not in compliance with the pandemic-safety considerations were most vulnerable to mass infections, that was predictable from the beginning.

During the lock-down in spring 2020, some large organisations hiring skilled labour transitioned to the Microsoft Teams platform, where communications were inundated by notifications and pop-ups. In addition, features allowed for time tracking and for a notification to appear when a certain person "appears online". A dialogue about abnormal expectations of synchronous work started to emerge; namely, that one could not discharge their functions as if the computer was simply moved from the office to the kitchen table. Toggling between the old "unpaid" labour and "paid" labour, employers perhaps began to panic that they were paying employees for "unpaid" work and started 
to increase surveillance and monitoring. Furthermore, they no longer received the unpaid paid labour that they previously enjoyed and that increased their profits through what Marx terms absolute surplus value production - the lengthening of the working day and of the increase of the amount of unpaid labour conducted per day.

Marxism defines the private property that drives the institution of the family as one of the core problems of inequalities within society and in families. The abolition of the family as a quest of Marx addressed a broader problem, it was a call for liberating individuals from inequality and systematic oppression, as well as creating space for communities that would represent a flattened structure of society. But what are the driving forces behind virtual communities?

\section{The Economy of the Sourdough in Digital Capitalism}

The outsourcing of schooling and social services along with the home office has created a new housewifisation trend. Women baking sourdough bread and posting images of it on Instagram during the COVID-19 lockdown are symbols of this new phase of housewifisation. The lockdown has just highlighted and reinforced how the economic circuit has become even more sophisticated in producing meanings to goods that have become even more abstract.

Mies $(1986,103)$ argues that the domestication and privatisation process of the housewife in the $19^{\text {th }}$ century fostered the construction of the image of the "good woman'. The COVID-19 lockdown confined women to the household where a set of housework chores had to be performed. We argue that the images of home-baked bread trending on social media during the time of the pandemic is a symbol of this contemporary domestication process that creates a certain image of the good woman leveraging between her paid and unpaid jobs. The privatised arena of consumption at home is exposed to digital communities.

Home-baked bread, a trend that swept across social media, sourdough and yeast have become scarce commodities (along with toilet paper). The public presentation of the self was recognised as being immanent to the capitalist mode of production (Read 2003) before the spread of social media in all sectors of economic organisation. The economic circuit thus captures the presentation of the self into a lock-in: images of a kind are being reproduced by the users for various reasons to present the informed image of the self and accumulate social capital. The trend of posting home-baked bread images online was based on the logic of precarious labour. There was a boost the sales of kits and packages designed for producing home-baked bread offered by bakers. There were also tutorials and live streamings.

Yeast and flour shortage hit the stores in March and April 2020 across the world. Bread is the symbol of survival, hospitality, and abundance that is deeply rooted in history. It represents culture, the miracle of agriculture and human ability to process grains, and cultivate sourdough or yeast to convert it into an edible product. Rituals of celebration of bread are part of numerous traditions. Civilisation is tied to the spread of organised agriculture, so is the rise of paired marriages and the patriarchal family, and the beginning of serfdom of women according to Engels. He writes, "Within the family he is the bourgeois; the wife represents the proletariat" (Engels 1891a, 181). Bread-baking was an inherent part of housework, a labour-intensive activity of the mother undertaken for feeding her family. With the increased division of labour in industrial societies, bakers became important players in the urban economy. Durkheim (1996; 1893) uses the image of the baker for illustrating how different household tasks have been taken over by newly emerging professions. Placing the bread back to the homes was not just the result of the "slow"-branded economy, but a response to the 
lockdown. The emerging community around home-based bread-baking was a globalised way of transmitting meanings of locality, home, and community at the time of the shock of the pandemic. The meaning of bread and the performing proficiency of breadbaking were forms of demonstrating culinary capital and an act of the social positioning of oneself (Easterbrook-Smith 2020). This also highlights how despite physical localisation globalisation is unfolding in the enhanced digital reality of the COVID-economy.

The competition of the home-bread beakers went along with proud images of all types of home-baking and cooking that presented the meritocratic message accomplishment. The processes of self-branding formalised by reality television and enhanced by the social media according to Hearn (2016) has intensified and

spread across the population at large. Indeed, the popularity and ubiquity of social media seem to confirm the centrality of socialized production, flexible, immaterial and affective labor and capitalism's "new" hidden abode of production (Hearn 2016, 11).

Digital reputation is a way of reinforcing the newly made "housewife" whose work is rendered invisible and being inaugurated as a new kind of labour in social media. Hearn argues that in the $21^{\text {st }}$ century this type of value creation is done in ways that are deeply gendered and recall the appropriation of women's work "inside and outside of the home by systems of capitalist expansion in the $16^{\text {th }}$ and $17^{\text {th }}$ centuries" (Hearn $2016,2)$. This lies in the logic of precarious and affective labour where the digitialised forms of human subjectivity are mingling with new forms of production. The socialisation of labour is a form of promotion of precarious forms of exploitation hiding the reality of the digital housewifisation processes accelerated by the lockdown. The mediatised vision of labour is structurally free of cost as labour and the invisible labour of housewives form a source of exploitation as a naturally occurring good (Mies 2007, 269).

The reality though was in contrast with this image for many affected severely by the lockdown either due to the loss of income and the pressure for survival, or the overwhelming tasks imposed on families confined to the home office. Decreased mobility in public spaces confined many to stay at home with abusive family members, moreover abusive tendencies were reported to rise as a consequence of the mental health crises that emerged due to the lockdown. The process of housewifisation and the shift of precarious and (paid) work on women confined to their homes has brought several consequences, that are the subject of contemporary studies.

What we know is that this process has been radical and affected the masses (Fuchs 2020). What we also know is that along with the burnout, the need for "catching up" and the "fear of missing out". parents with families have to push themselves toward performing more. Colleagues with no families had the space for working from home in a calm environment boosting their performance. Parents with children may have felt disproportionately hindered in their performance finding themselves worried about the future of their careers.

This type of slavery pushed many toward putting more self-imposed chains, selfexploitation, on themselves. The shift of performance to digital platforms has opened the path for self-slavery, voluntary servitude, as mode to transgress "obstacles of growth". The decelerated public life in the public physical space has accelerated forms of self-deployment. Wage-work and non-wage work have transgressed the boundaries of personal space deploying the remnants of personal and family time. Wages have not increased, placing more labour demands on the workers fighting to keep their jobs. In the wake of the lockdowns optimistic views on newly-gained space for solidarity in 
the society along with the perceived threats of alienation have been expressed (Fuchs 2020). By the last quarter of 2020 we see that some economic sectors have been affected more severely than others, deepening class divisions in societies.

\section{Conclusion}

The dissolving of physical spaces during the COVID-19 crisis reinvigorated a basic idea of Marx and Engels; namely, the delimitation between paid and unpaid labour, public and private spheres. We can observe spill-overs across spheres more closely as women are exploited in a two-fold manner during the COVID-19 crisis. We demonstrate that spill-overs have crept up on us slowly: There is the exploitation of women in the digital economy that is mediated by social media. And there is voluntary exploitation due to women's desire to achieve "the ideal pair" of superwoman in monogamous, paired marriage. This paper serves as a reminder of the blurring of social spheres and their gendered demarcations, as we witness the return to the household as the central unit of society. This shift provides evidence that the essential truths presented by Engels in the $19^{\text {th }}$ century can be employed to understand our reality during the COVID crisis.

What applies to the woman in the factory applies to her in all branches of business, right up to medicine and law. The modern individual family is based on the overt or covert domestic slavery of the woman; and modern society is a mass composed solely of individual families as its molecules (Engels 1891a, 181).

\section{References}

Dén-Nagy, Ildikó. 2018. Problem Solver or Private Life Killer? Mobile Telephony and WorkLife Balance in Hungary. PhD Thesis. Budapest: Budapest Corvinus University, Sociology Doctoral School.

Dewitte, Marieke, Chantelle Otten, and Lauren Walker. 2020. Making Love in the Time of Corona - Considering Relationships In Lockdown. Nature Reviews Urology 17: 547-553

Durkheim, Emile. 1893. The Division of Labour in Society. Trans. W. D. Halls, intro. Lewis A. Coser. New York: Free Press.

Easterbrook-Smith, Gwyn. 2020. By Bread Alone. Baking as Leisure, Performance, Sustenance, During the COVID-19 Crisis. Leisure Sciences. Online First.

Engels, Friedrich. 1891a. The Origin of the Family, Private Property and the State. In the Light of the Researches by Lewis H. Morgan. In Marx \& Engels Collected Works (MECW) Volume 26, 129-276. London: Lawrence \& Wishart.

Engels, Friedrich. 1891b. To the Early History of the Family (Bachofen, McLennan, Morgan). Preface to the Fourth German Edition of The Family, Private Property, and the State. In Marx \& Engels Collected Works (MECW) Volume 27, 203-214. London: Lawrence \& Wishart.

Fuchs, Christian. 2020. Everyday Life and Everyday Communication in Coronavirus Capitalism. tripleC: Communication, Capitalism \& Critique 18 (1): 375-399.

Hearn, Alison. 2016. Witches and Bitches: Reality Television, Housewifization and the New Hidden Abode of Production. European Journal of Cultural Studies 20 (1): 10-24.

Mestre-Bach, Gemma, Gretchen R. Blycker, and Marc N. Potenza. 2020. Pornography Use in the Setting of the COVID-19 Pandemic. Journal of Behavioral Addictions 9 (2): 1-3.

Mies, Maria. 2007. Patriarchy and Accumulation on a World Scale - Revisited (Keynote I'Lecture at the Green Economics Institute, Reading, 29 October 2005). International Journal of Green Economics 1 (3-4): 268-275. 
Mies, Maria. 1986. Patriarchy and Accumulation on a World Scale. Women in the International Division of Labour. London: Zed.

Mies, Maria, 1982. The Lace Makers of Narsapur: Indian Housewives Produce for the World Market. London: Zed.

Molodikova, Irina. 2013. Growing Up in the North Caucasus Society, Family, Religion and Education. Abingdon: Routledge.

Nisbet, Robert. 1953. The Quest for Community: A Study in the Ethics and Order of Freedom. New York: Oxford University Press.

Neilsen, Brett and Ned Rossiter. 2008. Precarity as a Political Concept, or, Fordism as Exception. Theory, Culture and Society 25 (7-8): 51-72.

ONS. 2020. Coronavirus and How People Spent Their Time Under Lockdown: 28 March to 26 April 2020. London: Office for National Statistics.

Piketty, Thomas. 2013. Capital in the 21st century. Cambridge, MA: Harvard University Press.

Prügl, Elisabeth. 1996. Home-Based Workers: A Comparative Exploration of Mies's Theory of Housewifization. Frontiers: A Journal of Women Studies. 17 (1): 114-135.

Putnam, Robert D. 2000. Bowling Alone. The Collapse and Revival of the American Community. New York: Simon and Schuster.

Read, J. 2003. The Micro-Politics of Capital: Marx and the Pre-History of the Present. Albany, NY: State University of New York Press.

Weissbourd, R., Batanova, M., McIntyre, J., \& Torres, E. 2020. How the Pandemic is Strengthening Fathers' Relationships With Their Children. Accessed 9 November, 2020. https://mcc.gse.harvard.edu/

\begin{abstract}
About the Authors
Julianna Faludi PhD

Julianna Faludi is a Sociologist interested in the relationship of Science, Technology and Society and Ethical Consumption. Her recent research interest unfolds around Social Innovation and Digital Entrepreneurship for Social Good.

Michelle Crosby

Michelle Crosby is an active Social Scientist with background in Research Methods and Evaluation working in the international affairs industry. She is interested in Teaching, Critical Theory and Analysis, Quantitative Research, Qualitative Research and Research Design.
\end{abstract}




\title{
On the Categories of Possibility, Limiting Conditions and the Qualitative Development Stages of Matter in the Thought of Friedrich Engels
}

\author{
Klaus Fuchs-Kittowski
}

\section{Leibniz-Sozietät der Wissenschaften, Berlin, Germany, fuchs-kittowski@t-online.de}

\begin{abstract}
The contradictory character of matter is the starting point of Friedrich Engels's dialectical principles. Matter can move itself, thus producing ever new possibilities of development and gradually leading to the formation of qualitatively higher forms of movement of matter. In this dialectical conception of development, the explanation of qualitative change is fundamental. Starting from the understanding that the inner contradiction is the source of development and its potential, the transition to a new quality is verifiable. Probabilistic laws are the expression of the unity of necessity and chance in the real possibility. Limiting conditions, like specific structures, informational coupling and whole-part relationships and selection processes, restrict the field of possibilities opened by physical laws. This restriction of possibilities on the lower level opens up new possibilities of development on the higher level, where the transition to a new quality is realised. Materialist and dialectical thinking is the important basis of a theory of biology that is neither physicalist nor vitalist, of a theory of computer science that is neither physicalist nor dualist. Mechanistic thinking - reductionism, the denial of the specific qualities of the different forms of movement of matter - leads to philosophies that reduce the human being to an animal or computer and is both dangerous and inhuman. Computer science needs to engage with the history and application of materialistic and dialectical thinking. It needs to grasp the dialectical unity of similarity and difference between automaton and human in the concrete process of digitalisation and automation. It must overcome the widespread, increasing interest in reducing the human being to an automaton, in order to maintain the unique quality of the human being. It must protect and enhance the special qualities and abilities of human beings. The danger of anti-dialectical thinking, of modern forms of reductionism and the possibility, indeed necessity, of creating a better society, free from profit, greed and war is discussed in this paper in the context of Engels's 200th birthday.
\end{abstract}

Keywords: movement of matter, evolution, development, materialistic and dialectical thinking, mechanistic thinking, specific quality, possibilities, limiting conditions, Friedrich Engels

\section{Internal Contradictions of Matter as the Source of Development}

The contradictory character of matter enables it to move and structure itself, producing ever new possibilities for development. This gradually leads to the formation of qualitatively higher forms of movement of matter and is the starting point of Friedrich Engels's dialectical principles. In the dialectical concept of development, qualitative change is fundamental. Today - because of the findings of quantum physics, the theory of dissipative structures, self-organisation theory, and modern systems theory we can speak in much greater detail about the emergence of the human mind. We can describe more precisely the concept of "possibility" as it has been developed in the modern natural sciences and philosophy. Thus, the transition from one form of movement of matter to another, creating a qualitatively higher form, can be understood with greater precision. The inner contradiction is a source of ever new possibilities of de- 
velopment: understanding the probabilistic laws of quantum physics as a unity of necessity and chance in the real possibility means that new things can appear in nature. Limiting conditions such as specific structures, informational couplings, and the effects of the whole on the development of its parts, restrict the field of possibilities and enable higher forms of the organisation of matter to be formed and with that the transition to a new quality. The development of higher forms of organisation is the prerequisite for new, qualitatively higher forms of the movement of matter in Engels's sense.

\section{A Stage Model of Evolution}

The Stage Model of Evolution (Wahl 2012, 15; see Figure 1) connects the basic ideas presented in the evolutionary step model of information (Fuchs-Kittowski 1997, 551570; Fuchs-Kittowski 1992, 416-432) with Engels's concept of qualitatively different forms of the movement of matter. The scheme sets out the development potentials and interactions or characteristics underlying evolution.

According to Engels, the process of development on our earth led to qualitatively different forms of the movement of matter. Nikolai Hartmann (1935-1950) explains development in the form of new, different stages of being. This differentiation between qualitatively different forms of the movement of matter that arose during evolution represented important progress in philosophical ontology. Whereas previously the focus had been on finding a uniform being, this was now abandoned.

Understanding the changed ontology of classical physics is essential. In classical thinking about physics, the past determines everything - everything is pre-determined. Since the past cannot be changed, neither can the future. All human activity and desire are ultimately no more than an accompaniment of a predestined event. This is a deeply pessimistic world view. Quantumphysics was by contrast hugely liberating in its recognition of objective chance, in unity with necessity - that is, in its probabilistic laws. Philosophy needs to see the potentiality of matter, liberation from pre-determination, and the openness of the future (Fuchs-Kittowski 1976).

Engels offered philosophers and natural scientists a valuable orientation for such insights. He wrote:

cause and effect are conceptions which only hold good in their application to individual cases; but as soon as we consider the individual cases in their general connection with the universe as a whole, they run into each other, and they become confounded when we contemplate that universal action and reaction in which causes and effects are eternally changing places, so that what is effect here and now will because there and then, and vice versa (Engels 1925, 23). 


\begin{tabular}{|c|c|c|c|c|c|c|c|}
\hline & Special Laws & Role of Information & $\begin{array}{l}\text { Relation Hu- } \\
\text { mans-Environ- } \\
\text { ment }\end{array}$ & $\begin{array}{l}\text { Mode of Re- } \\
\text { production }\end{array}$ & Variability & Value/Purpose & $\begin{array}{l}\text { Subjec- } \\
\text { tivity, } \\
\text { Self- } \\
\text { hood }\end{array}$ \\
\hline $\begin{array}{l}\text { Socio-Psy- } \\
\text { chological } \\
\text { Sphere }\end{array}$ & $\begin{array}{l}\text { relation of productive forces } \\
\text { and relations of production, } \\
\text { base/super-structure, inter- } \\
\text { nal and external behaviour }\end{array}$ & $\begin{array}{l}\text { culture, consciousness, } \\
\text { language, thinking, in- } \\
\text { formation from the re- } \\
\text { mote realm of pragmat- } \\
\text { ics }\end{array}$ & work & $\begin{array}{l}\text { development of } \\
\text { production, cul- } \\
\text { tural heritage, } \\
\text { socialisation }\end{array}$ & $\begin{array}{l}\text { historical con- } \\
\text { sciousness, } \\
\text { creativity, } \\
\text { learning }\end{array}$ & $\begin{array}{l}\text { conscious norms, } \\
\text { value system, } \\
\text { purposes }\end{array}$ & $\begin{array}{l}\text { persons, } \\
\text { society }\end{array}$ \\
\hline Biology & $\begin{array}{l}\text { dynamic equilibrium, evolu- } \\
\text { tion, information }\end{array}$ & $\begin{array}{l}\text { stimulus-response, ge- } \\
\text { netic information, infor- } \\
\text { mation from the close } \\
\text { realm of semantics }\end{array}$ & $\begin{array}{l}\text { Metabolism and } \\
\text { information-ex- } \\
\text { change, immune } \\
\text { system }\end{array}$ & $\begin{array}{l}\text { Autopoiesis, } \\
\text { cell division, } \\
\text { genetic mate- } \\
\text { rial, }\end{array}$ & $\begin{array}{l}\text { Mutation, } \\
\text { learning, se- } \\
\text { lective learn- } \\
\text { ing }\end{array}$ & $\begin{array}{l}\text { Selection of val- } \\
\text { ues, purposes, } \\
\text { norms, and val- } \\
\text { ues }\end{array}$ & $\begin{array}{l}\text { Individu- } \\
\text { als, } \\
\text { cell- } \\
\text { units, } \\
\text { species }\end{array}$ \\
\hline Chemistry & $\begin{array}{l}\text { Constant mass relation- } \\
\text { ship, chemical equilibrium, } \\
\text { RGT rule }\end{array}$ & $\begin{array}{l}\text { Signal, potential infor- } \\
\text { mation, syntax }\end{array}$ & & & & & none \\
\hline Physics & $\begin{array}{l}\text { Laws of conservation, four } \\
\text { basic forces, relativity the- } \\
\text { ory, quantum theory }\end{array}$ & no Information & $\begin{array}{l}\text { Dissipative struc- } \\
\text { tures, phase } \\
\text { transition, sym- } \\
\text { metry breaks }\end{array}$ & & & & none \\
\hline
\end{tabular}

Figure 1: Stage Model of Evolution, created by Klaus Fuchs-Kittowski and Dietrich Wahl 
These processes and methods of thinking do not fit into the framework of metaphysical thinking. For dialectical philosophy, on the other hand, because it understands things and their conceptual images essentially in their context - their interconnections, their movement, their emergence and passing - processes are the confirmation of their own method. Engels writes:

Nature is the proof of dialectics, and it must be said for modern science that it has furnished this proof with very rich materials increasing daily, and thus has shown that, in the last resort, nature works dialectically and not metaphysically; that she does not move in the eternal oneness of a perpetually recurring circle but goes through a real historical evolution. In this connection Darwin must be named before all others. He dealt the metaphysical conception of Nature the heaviest blow by his proof that all organic beings, plants, animals, and man himself, are the products of a process of evolution going on through millions of years (Engels 1925, 633).

For Engels, who developed dialectical thinking and made it fruitful especially for the natural sciences, ultimately only necessary development happens. Chance remains in the end only an appearance. With his famous pea example (Engels 1925, 499) he does indeed acknowledge the role of coincidence, but in the end, even for Friedrich Engels, coincidence is no more than an appearance of being, of the natural process that necessarily takes place. Engels knew only classical statistics, not quantum statistics. It must be noted that Marx and Engels based their considerations not only on Hegel, but especially also on Charles Darwin, so that they went beyond the Hegelian dialectic in their understanding of dialectic development. The dialectic is not simply a matter of turning Hegel "from head to toe". For the rediscovery of a materialistic, dialectical conception of development, undistorted by pre-deterministic or teleological positions, the development of the theory of irreversible thermodynamics by llya Prigogine and his Brussels school was an important step- that is, the discovery of dissipative structures, which show a self-structuring of matter far from the thermodynamic equilibrium.

Prigogine, a Nobel Prize winner for chemistry, opened up new paths of scientific thinking that bear fruit now also in the social sciences. He explicitly recognises Karl Marx and Friedrich Engels as pioneers in the study of the evolution of nature. Prigogine and Stengers, in their book Order out of Chaos: Man's New Dialogue With Nature, write:

We have described in Chapters V and VI a nature that might be called "historical"-that is, capable of development and innovation. The idea of a history of nature as an integral part of materialism was asserted by Marx and, in greater detail, by Engels. Contemporary developments in physics, the discovery of the constructive role played by irreversibility, have thus raised within the natural sciences a question that has long been asked by materialists (Prigogine and Stengers 1984,252$)$.

With the theory of self-organisation and evolution developed by Peter Glansdorf and Ilya Prigogine (1971), Manfred Eigen (1971), Werner Ebeling (2016, 63-74), Rainer Feistel (Ebeling and Feistel 2014, 141-184) and other students of biophysics, the dialectic of necessity and chance and the dialectic of part and whole have been understood more deeply and the connection between the self-organisation of matter and the creation of biological information has become understandable. 
A generalised, basic process of the evolution to higher forms of the movement of matter can be derived from self-organisation theory. Due to its internal contradictions, matter is constantly creating new possibilities for development. At the lower levels, these developmental possibilities are affected by limiting conditions, for example through specific structures, informational couplings, partial-whole relationships, and selection processes. But what appears as a limitation at lower levels, at higher levels opens up new development possibilities.

A particular example is that whereas thermodynamically many chemical reactions are possible, only extremely specific chemical processes are realised in the living organism. The field of possibilities spanned by the physical-chemical laws is restricted and thus opens up on a higher level the possibilities of biological evolution. At the lower level, however, pre-conditions for this qualitative change are also created. Without these pre-preconditions the qualitative change could not be explained. The new does not come out of nothing.

\section{Neither a Physicalist nor a Vitalistic Theory of Biology}

\subsection{Stricter Internal Determination Through Informational Coupling as Basis for the Specific Quality of the Living}

For theories and modelling in biology, an accurate understanding of the relationship between physics, chemistry, and biology is the essential challenge. In Dialectics of Nature, Engels understands these relationships in the following manner:

Physiology is, of course, the physics and especially the chemistry of the living body, but with that it ceases to be specially chemistry: on the one hand its domain becomes restricted but, on the other hand, inside this domain it becomes raised to a higher power (Engels 1925, 535).

With Engels's approach a possible basis emerges for a neither mechanistic nor physicalist nor vitalistic understanding of the relationship between physics, chemistry, and biology, to overcome the so-called mechanism vitalism controversy. This controversy has already been raging for centuries in philosophy and biology and, with the successes of molecular biology and research in the field of artificial intelligence, has flared up again today.

Physiology is, as Engels says, physics and especially chemistry, but it limits its perimeter and rises to a higher potency. We can today say: Life is physics and chemistry organised by information. Information is understood as effects organising effect.

Today, especially on the basis of the work on the self-organisation of matter of the Brussels School around Prigogine and the molecular Darwinian theory of the origin of life of Manfred Eigen, the analysis of the origin of macromolecules and thus of the origin of biological information can be made much more precise.

The revolution in biology since the middle of the last century was primarily determined by the fact that the elementary foundations of biological processes became accessible to analysis and synthesis. There is a far-reaching analogy with the revolution in physics at the beginning of the last century.

The ancient questions "What is life?", "What is its specificity?", "How is life determined?", and "Through what processes (mechanisms) is the quality of life created?" are today the subject of research that used modern methods of molecular biology (Fuchs-Kittowski, Rosenthal and Rosenthal 2005, 149-162; 219-234). 
Not only many biologists, biochemists and molecular biologists, but also philosophers saw this successful scientific development as a victory for reductionism or physicalism. However, this proved to be a misjudgement. Complex life processes can be traced back to the elementary structures and processes on which they are based, since the macromolecules and their interactions are components of these life processes, but the available knowledge is usually insufficient for understanding the whole.

Just as the quantum physicist learned that the images of wave and corpuscle interaction modify each other, the biologist had to learn that the organism cannot simply be disassembled into its parts and then put back together again like a machine. If we start from the whole and proceed to analyse the parts, something is lost that cannot be recovered simply by putting the parts together. The whole, the organisation of the living, modifies the parts, so in reverse the elementary processes underlying the whole are the bearers of the organisation, the components of the whole. Thus, when we study the processes of life, we are dealing neither with a purely physical-chemical process nor with a purely biological process of some kind. Life is neither a purely physical machine nor a purely biological event, detached from physics and chemistry, but a third phenomenon. From the outset, we are dealing with specific biological processes. We confront ourselves today with descriptive models of automation technology, e.g. with artificial neural networks. We must be aware, however, that these models must be extended or modified if we really want to grasp the new developmental possibilities of matter, which result from the restriction of the possibilities given by the laws of physics and chemistry by the organic whole.

Therefore, we deliberately do not speak of complementarity here, but rather of the modification of the physico-chemical processes by the conditions restricting the physico-chemical processes, such as specific structures, informational coupling, and wholepart relationships. This is expressed as follows: everything that is biologically possible must be physically possible too, but the reverse is not true. Not everything that is physically possible is also biologically possible, for example a rotten egg (Fuchs 1972, 410417). In addition, there are the restricting conditions posed by the possibilities of physical-chemical laws.

In a living (dialectical) whole, in contrast to the mechanical whole of a computer, the relations of the whole to its parts and thus a substantial determination is lost if one limits oneself to the analysis of the parts and their interrelationships. For these do not result from this order and organisation but from the overall organisation. These relations and interactions, especially the effect of the whole on its parts, cannot be disregarded.

\subsection{The Evolution of the Human Being}

\subsubsection{Stronger Inner Determination Caused by the Free Will of the Human Being}

With the capacity for semantic information processing, with the development of human language as an instrument of symbolic knowledge about objective reality, our knowledge became transferable and the possibility of social transmission developed. In addition to biological evolution based on biological inheritance, social evolution based on the transmission of social experience arose, and it is no longer necessary to experience everything oneself in order to understand a certain fact.

Biological evolution is based on the selection of genetic structures through reproductive success. Human evolution is based on the social transmission of knowledge that is effective in tools or in the differentiation of work organisation. The possibility of 
alienating or objectifying information leads to this comparatively rapid social development.

Even if the human being cannot escape the effects of biological evolution, the latter is increasingly receding into the background as a determinant. Acclimatisation of humans to their environment is achieved not so much by changing the genetic make-up of humankind, but rather by changing the environment and redesigning it to suit human purposes. "With man", says Engels,

we enter history. Animals also have a history, that of their descent and gradual evolution to their present position. This history, however, is made for them, and in so far as they themselves take part in it, this occurs without their knowledge and desire. On the other hand, the more the human beings become removed from animals in the narrower sense of the word, the more they make their history themselves, consciously, the less becomes the influence of unforeseen effects and uncontrolled Introduction forces on this history, and the more accurately does the historical result correspond to the aim laid down in advance (Engels 1925, 330-331).

The qualitative change is achieved by a new degree of freedom. In place of the reflex actions and the automatic behaviour of animals, in human beings there is conscious decision-making and conscious self-control. Humans can also display behaviour similar to that of automatons through practiced conditional reflexes or rules imposed from the outside. By conscious decisions and conscious self-control, they can overcome machine-like behaviour and behaviours that correspond to them more as animals than as social human beings.

\section{The Danger of Anti-Dialectical Thinking and of Modern Forms of Reductionism in Our Time}

\subsection{Against the Reification and the Degradation of the Living}

Living organisms and their usefulness are so impressive that many people see them as the expression of a planning and ordering force, proof of the existence of a first intelligent designer. Scientific method, however, has at is centre the assumption that nature existed before humans and humans before the natural sciences, and that there has been a development towards qualitatively higher forms of organisation of matter that are neither predestined nor foreplaned. This is where the natural differs fundamentally from the artificial. However, a theory of evolution is repeatedly distorted by predeterminism and teleological conceptions.

Engels writes in his work "Ludwig Feuerbach and the End of Classical German Philosophy" that

the materialism of the last century was predominantly mechanical [...] This application exclusively of the standards of mechanics to processes of a chemical and organic nature - in which processes the laws of mechanics are, indeed, also valid, but are pushed into the background by other, higher laws - constitutes one specific, but at that time inevitable, limitation of classical French materialism. The other specific limitation of this materialism lay in its inability to comprehend the world as a process, as matter undergoing uninterrupted historical development. This accorded with the state of the natural science of that time, and with the metaphysical, that is, anti-dialectical manner of philosophizing 
connected with it. Nature, so much was known, was in eternal motion. But according to the ideas of that time, this motion turned just as eternally in a circle and therefore never moved from the spot: it produced the same results over and over again. This conception was at that time inevitable (Engels 1888, 370).

Mechanistic, reductionist thinking, which disregards evolution and forgets the specific quality of life, becomes inhuman. This is especially an issue today, when digitalisation and the and use of computers and computer networks permeate all areas of our lives.

The reduction of human beings to animals, and the subsequent implied inferiority of certain human groups in biological and spiritual terms, was the key ideology behind both world wars. Humans reduced to a machine: the widespread postulate nowadays that automata can become superior beings contributed to the degradation of human beings and thus to racism and anti-Semitism, and today pose the threat of the next world war.

Life, with its unique, highly complex structure, is exposed to many dangers including, as many authors point out, changes in external conditions such as the greenhouse effect, but also and perhaps even more so a reductionist scientific and technical view of living and creativity. It is important to stress that it is not the discovery of nuclear fission and DNA, nor decoding of the human genome, nor the development of computers and now global digital networks - the Internet and the Internet of Things - that constitute this threat to our world. Rather, it is the degradation of the living, regarding everything and everyone as a usable resource to be treated accordingly. This ruthless urge to exploit, by which every new scientific hypothesis is immediately tested for its application and potential for profit, broadly characterises the current zeitgeist.

It is a legitimate aim of bio-medical research to uncover the causes of diseases which are still incurable today, such as Alzheimer's disease, cancer and Parkinson's disease, and to seek ways of curing them. Interventions in these complex life events are not hubristic. However, overambitious or misleading promulgation of scientific theory or intent as fact (e.g. untested COVID drugs), or the hasty introduction of new products driven by corporate greed, are violations of human rights, exploitative and display contempt for humanity.

It is the responsibility of science and scientists to ensure that important scientifictechnical developments, currently and especially in computer science and biology, are not misused and neither underestimate nor disregard the complexity and individuality of human beings.

The philosophy of mechanistic materialism, one outcome in the name of the great successes in modern science in biology and computer science, has also fed religious fundamentalist movements. If one defines the mind only as an information processor, reduced to signal processing or syntactic information processing, where science is distorted to show that humans and the computer are identical, and the mind is only hardware or wetware, neuronal connections (Crick 1994) or connections of small robots (Dennett 2005), we should not be surprised that a wish for an "intelligent designer" or a charismatic, authoritarian leader emerges in poor countries with few human prospects and even in rich countries where prospects for many decrease. The result is the wish for an "intelligent designer" (Numbers 2006). Even in Europe we now have mass movements based on fundamentalist, racist, fascist ideas. These movements despise rational thought and propagate acting based on feelings and ideology.

The reduction of humans to the machine, the currently widespread postulate that automata could even become better humans and a post-biological age could dawn, that human society could be replaced by an automated society, as argued by MIT robot 
developer Hans Moravec in his book Mind Children (Moravec 1990), can lead to the complete destruction of humanity. Even false ideas have power, as Joseph Weizenbaum (1976; 2001) and Benno Müller-Hill (1981) never tired of reminding us.

\subsection{Information Creation: An Essential Category for Model and Theory Development and as a General Guiding Principle of Methodology}

Reductionism in science as an ideological attitude can effectively be countered by working out the specifics of the living, especially the living in relation to the dead and the human being in relation to the technical automaton or autonomous robot. Weizenbaum asked Moravec whether he really thought that he could transfer the truly human, e.g. a smile of a young mother to her child, to robots. (Fuchs-Kittowski and Wenzlaff 1987, 502-511).

The learning automaton, such as the vehicle robot for so-called autonomous driving, receives its information and value system from the outside. As Eigen (1972, 171223), showed in his Darwin-based theory of the origin of life, the information and value systems must originate internally (Fuchs-Kittowski and Rosenthal 1972, 308-313).

The category of information creation proved essential in model and theory formation towards understanding the origin of life in the border area between physics, chemistry, and biology. Wherever functions need to be newly created and organised, new information and evaluations are required. Therefore, the category of information creation is as essential for the understanding of phylogenesis and ontogenesis, as well as for model and theory formation in the border area between computers (software) and the human mind, as well as between automaton-supported information systems (application systems) and creative learning social organisations. It is part of the responsibility of science, especially in biology and computer science theory, to bring this specificity of the living and humanity to bear, because this is the only way to guard against the degradation of humans through the automaton as well as to prevent further forms of discrimination.

There ae scientific-theoretical and methodological implications of the concept of creativity. The creation of information has gained in importance for almost all areas of scientific interest (Fuchs-Kittowski 2014; Hofkirchner 2011). In particular, there is methodological evidence for safer navigation between the Scylla of gross reductionism, inspired by $19^{\text {th }}$ century physics and $20^{\text {th }}$ century neurophilosophy and connectionist $\mathrm{Al}$ research that propagate a mind-brain identity, and the Charybdis of dualism, inspired by the vitalism of $19^{\text {th }}$ century Romanticism and the $20^{\text {th }}$ century functionalist bodymind or hardware-software duality of cognitivist Al research.

The basis for post-humanistic and other anti-humanistic concepts is the reduction of the human being to an information system and the reduction of information to its syntactic structure. This accords with the information processing approach of classical Al research. The central role of creativity, the origin of information in the living, in innovative thought and the develop of social organisations, helps us understand humancomputer interaction as a coupling of machine (syntactic) information processing with the creatively active human being that is capable of semantic information processing. In this way the goal of automation is not super automation, i.e. the complete replacement of humans. Humanity requires the meaningful coupling of the specific abilities of computers and humans so that anti-human ideas lose theoretical and practical ground (Fuchs-Kittowski 1981, 275-285; Fuchs-Kittowski 2006, 431-444; Fuchs-Kittowski 2016, 10-2). 


\section{The Evolution of Society}

\subsection{Stronger Determination of Social Processes Through the Conscious Organisation of Social Production}

Only the conscious organisation of production enables the human to be a human being. Friedrich Engels writes in his work Dialectics of Nature that

only conscious organisation of social production, in which production and distribution are carried on in a planned way, can lift mankind above the rest of the animal world as regards the social aspect, in the same way that production in general has done this for mankind in the specifically biological aspect. Historical development makes such an organisation daily more indispensable, but also with every day more possible (Engels 1925, 331).

This resonates with us today. One reason is that software development accelerates the objectification of mind. The objectification of mind in software by means of machineprocessable syntactic structures leads to the socialisation of knowledge. For example, the knowledge worker has the skills of the previous typist at his or her disposal and the skills of a translator, and the experimental physicist has the physical theory at his or her disposal. The more mental expression or objectification increases, the less intellectual follow-up of the objectified, social processes is necessary and feasible, the more human individuality is set free and can become an essential factor in human development.

When the intellectual and practical follow-up of human activities is less and less necessary or feasible, however, there is also the danger of a decline of abilities and that humans are left behind (Carr 2014). In capitalist society, the socialisation of knowledge through its objectification in software also increases the contradiction between societal production and private appropriation (Fuchs 2014, 2020).

Right now, therefore, the aim must be to counteract the monopoly power of the large digital platform providers, whose business models build behavioural profiles over large parts of the world's population. This new capitalism, called "surveillance capitalism" by Shoshana Zuboff (2019), works by providing free services that are happily used by billions of people. It can enable providers of these services to change the behaviour of these users in astonishing and often very precise ways, often without their explicit consent. Behavioural predictions secretly derived from user monitoring are exploited (Landwehr, Borning and Wulf 2019).

As Die Welt am Sonntag (19 April 2020, 32) recently reported, we are today in a "near-total dependence on Amazon's cloud". Legal regulations are needed to counter the power of such super monopolies, the dominance of their platforms and the associated social models. In addition, Europe needs to create its own software-orgware system and IT infrastructures that are keeping up and advancing the tradition of European work culture. Real social transformation is necessary today (Fuchs-Kittowski 2020, 83113)

For Marx, the decisive factor of automation as a social process is not the oftenquoted withdrawal of humans from the immediate production process. This is only the external site of the automation process. For Marx, the essence of automation as a social process consists in "the free development of individuality" (Marx 1857/1858, 706), based on "the appropriation of his [the individual's] own general productive power" (Marx 1857/1858, 705).

Marx (1857/1858, 705) wrote: 
In this transformation, it is neither the direct human labour he himself performs, nor the time during which he works, but rather the appropriation of his own general productive power, his understanding of nature and his mastery over it by virtue of his presence as a social body - it is, in a word, the development of the social individual which appears as the great foundation-stone of production and of wealth.

The insight that captures the essence of the process of digitalisation and automation is therefore that through the integration of machine operations into the individual activity of the human being a directly productive appropriation of all those objectified creative forces of human society takes place, leading to these automated operations. For this appropriation one needs of course more free time, which requires the full development of the individual, but also the individual's possibility of becoming the owner and determiner of his or her own general productive force.

\subsection{Human Emancipation}

According to our thesis that every transition to a higher form of movement of matter is based on a stronger inner determination, rooted in the nature of the carriers of the relevant form of movement, the transition to the social form of movement of matter and its further development is increasingly determined by the nature of the human being, to be a human being among human beings. As with the emergence of life through the dialectical relationship between the biological whole and its parts, a further determining factor occurs here. Conscious decision-making and conscious self-control are all the more effective the more comprehensive the knowledge of the laws of nature and society, and the deeper the understanding of fellow humans and the self as social being.

People can behave like animals but do not have to. People can behave like computers but do not have to. The free will and inner determination of human beings can be powerfu. (Fuchs-Kittowski 2013, 41-42).

The humanist and critical spirit of the Enlightenment, carried forward to our humanism of today, means that human progress consists not only in a growing mastery of the forces of nature and society, but also in achieving new levels of self-understanding and thus new dimensions of human freedom.

Insight into the necessity of the external conditions that a person must understand in order to transform them according to their own needs and desires provides the means to fulfil needs and desires, but not the deeper goal of this effort. The deeper goal is the awareness that we all are human beings among other human beings. The insight into the inner necessity as a human being enables working for the creation of a society humans deserve. It can, like the brave antifascists in the concentration camps set up by the Nazis, provide the strength not to break down in the face of external adversities. That is true autonomy!

In his work "On the Jewish Question", Marx writes that it is wrong to reduce human emancipation to no more than the political objective of the French Revolution - the "free state" rather than free humanity. He says:

All emancipation is a reduction of the human world and relationships to man himself. [...] Only when the real, individual man re-absorbs in himself the abstract citizen, and as an individual human being has become a species-being in his everyday life, in his particular work, and in his particular situation, only when man has recognized and organized his 'forces propers' [own powers] as social powers, and, consequently, no longer separates social power from himself in 
the shape of political power, only then will human emancipation have been accomplished (Marx 1844, 168).

Marx and Engels' argument that all emancipation is the return of the human world to the human being itself extends Hegel's concept of Becoming Subject. This concept requires not just a theoretical understanding but is about the design of social production. Only thus is human emancipation achieved.

In this conception of society, concrete humans, united subjects in their consciously designed frameworks, will not be angels. Internal contradictions will drive further developments. But there is always the hope that the contradictions of a society driven by profit will be overcome. It is therefore necessary that humans actively and consciously shape social processes and do so self-confidently and with purpose. This could transform still largely unreasonable social practices into a rational way of living together that realises concrete humanism.

\subsection{A World Without War Is and Must Be Possible!}

The fundamental vision connected with the development of cybernetics and now with the development of global, digital networks is that of a world of people communicating with each other (as Norbert Wiener and J.C.R. Licklider pointed out), as a basis for a "world without war" (see Hauben and Hauben 1997; Hauben 2004, 267-281). Today, however, we experience the opposite. Digital networks have become the basis for cyberwars. It is important to remember how important the end of the Cold War was, and how dangerous it is that humans are already talking about the beginning of a new Cold War or, as Horst Teltschik, Helmut Kohl's foreign policy advisor, puts it, to slide "From the Cold War to the Cold Peace" (Teltschik 2019). A key perception in Teltschik's book is that during the Cold War there was always a diplomatic connection to a wider world, in the then shape of the Soviet Union. Today our increasingly fragmented world and growing nationalism in various countries brings with it greater and greater isolation.

This situation is an example of how in evolution and also in the history of humankind, opportunities that arise are missed. After the end of the Cold War there was a real possibility of disarmament. The vision of the "common house of Europe" seemed to be generally accepted. This great opportunity appears so far to have vanished.

Such developments should serve as a reminder to us that there is not only continuous development, but also regression. As Engels wrote, "according to Hegel, infinite progress is a barren waste because it appears only as eternal repetition of the same thing: $1+1+1$, etc. In reality, however, it is no repetition, but a development, an advance or regression, and thereby it becomes a necessary form of motion." (Engels 1925,517 )

There is the real possibility of creating a better society, but also the real possibility of cyberwar and nuclear war. Therefore, it is necessary to recall the historical experience of the small steps in understanding that were crucial in ending the Cold War. In the nuclear age it is irrational to regard war as a suitable means of restoring violated rights. In view of the danger of the annihilation of humanity, there is no just war or just revolution that would justify the use of such weapons. Social injustices should be overcome by peaceful means.

There were always people who thought ahead, who had their own thoughts and values. I am convinced that this will also characterise the future generations of humans who will question the given and seek change and who will try to improve the society in which we live. A world without war is and must be possible and also a world will come, 
where the contradictions of past society will be overcome and the free development of the individual becomes the precondition of the free development of all.

\section{References}

Carr, N., Nicolas. 2014. Abgehängt - Wo bleibt der Mensch, wenn Computer entscheiden? Hanser: München.

Crick, Francis. 1994. What the Soul Really Is: The Scientific Investigation of Consciousness. Munich: Artemis \& Winkler.

Dennett, C. Daniel. 2005. Sweet Dreams: The Exploration of Consciousness and the Sleep of Philosophy. Cambridge, MA: The MIT Press.

Ebeling, Werner. 2016. Physik, Biologie, Technik und Selbstorganisation der Information. In Informatik und Gesellschaft - Festschrift zum 80. Geburtstag von Klaus Fuchs-Kittowski, edited by Frank Fuchs-Kittowski, Werner Kriesel. Frankfurt am Main: Peter Lang.

Ebeling, Werner and Rainer Feistel. 2014. Selforganisation of Symbols and Information. In Chaos, Information Processing and Paradoxial Games: To the Memory of John S. Nicolis, edited by Gregoire Nicolis and Vasileios Basios, 141-184. Singapore: World Scientific.

Eigen, Manfred. 1972. Molecular Self-Organization and Evolution. In Informatik, Nova Acta Leopoldine, edited by Joachim-Hermann Scharf, 171-223. Leipzig: Johann Ambrosius Barth.

Eigen, Manfred. 1971. Selforganization of Matter and the Evolution of Biological Macromolecules. Die Naturwissenschaften 58 (10): 465-523.

Engels, Friedrich. 1925. Dialectics of Nature. In Marx \& Engels Collected Works (MECW) Volume 25, 311-588. London: Lawrence \& Wishart.

Engels, Friedrich. 1888. Ludwig Feuerbach and the End of Classical German Philosophy. In Marx \& Engels Collected Works (MECW) Volume 26, 353-398. London: Lawrence \& Wishart.

Engels, Friedrich. 1878. Anti-Dühring. Herr Eugen Dühring's Revolution in Science. In Marx \& Engels Collected Works (MECW) Volume 25, 5-309. London: Lawrence \& Wishart.

Fuchs, Christian. 2020. Marxism: Karl Marx's Fifteen Key Concepts for Cultural and Communication Studies. New York: Routledge.

Fuchs, Christian. 2014. Digital Labour and Karl Marx. New York: Routledge.

Fuchs, Klaus. 1972. Über die Kategorie der Möglichkeit und die Entwicklungsstufen der Materie. Deutsche Zeitschrift für Philosophie 20 (4): 410-417

Fuchs-Kittowski, Klaus. 2020. Zur Verantwortung der Wissenschaft für die Gewährleistung der Menschenrechte - Im Kampf gegen die Degradierung des Menschen, Rassismus und Antisemitismus. In Wissenschaftsforschung, Jahrbuch 2019, edited by Harald Mieg, Hans Lenk, Heinrich Parthey, 112-147. Berlin: Wissenschaftlicher Verlag Berlin.

Fuchs-Kittowski, Klaus. 2018. Zur Entstehung und Erhaltung von Information in lebendiger Organisation - Grundkategorien einer Theorie der Biologie und der Informatik, Vortrag auf dem Kolloquium „Emergente Systeme. Information und Gesellschaft“ am 10.12.2015. Leibniz Online 32 (2018) Zeitschrift der Leibniz-Sozietät e. V. https://leibnizsozietaet.de/wp-content/uploads/2018/03/Fuchs-Kittowski.pdf

Fuchs-Kittowski, Klaus. 2016. Stellung und Verantwortung des Menschen in komplexen informationstechnologischen Systemen in Organisationen, Informationsmanagement, Wirtschaftsinformatik \& Management 8 (2): 10-21.

Fuchs-Kittowski. Klaus. 2014. The Influence of Philosophy on the Understanding of Computing and Information. In Philosophy's Relevance in Information Science, edited by Ruth Hagengruber and Uwe V. Riss, 45-56. London: Pickering \& Chatto.

Fuchs-Kittowski, Klaus. 2013. Ethik und Informatik - Moralität und Historizität - Zur notwendigen Solidarität mit den Whistleblowern, Weltweite Datenausspähung. FlfF-Kommunikation 3: 41-42.

Fuchs-Kittowski, Klaus. 2006. Strategies for an Effective Integration of ICT into Social Organization - Organization of Information Processing and the Necessity of Social Informatics. 
In Social Informatics: And Information Society for ALL? - In Remembrance of Rob Kling, edited by Jacques Berleur, Markku I. Nurminen, John Impagliazzo, 431-444. Heiderlberg: Springer.

Fuchs-Kittowski, Klaus. 1997. Information-Neither Matter nor Mind - On the Essence and on the Evolutionary Conception of Information. World Futures. 50 (1-4): 551-570.

Fuchs-Kittowski, Klaus. 1992. Reflections on the Essence of Information. In Software Development and Reality Construction, edited by Christiane Floyd, Heinz Züllighoven, Reinhard Budde und Reinhard Keil-Slawik, 416-432. New York: Springer Verlag.

Fuchs-Kittowski, Klaus. 1976. Probleme des Determinismus und der Kybernetik in der molekularen Biologie, Tatsachen und Hypothesen über das Verhältnis des technischen Automaten zum lebenden Organismus. Jena: VEB Gustav Fischer Verlag. http://www.max-stirner-archiv-leipzig.de/dokumente/Fuchs-Kittowski-Determinismus.pdf

Fuchs-Kittowki, Klaus and Hans A. Rosenthal. 1972. Self-organisation and Evolution. Wissenschaft und Fortschritt 22 (7): 308-313.

Fuchs-Kittowski, Klaus, Hans A. Rosenthal, and André Rosenthal. 2005. Die Entschlüsselung des Humangenoms - anbivalente Auswirkungen auf Gesellschaft und Wissenschaft. \& Replik: Geistes- und Naturwissenschaften im Dialog Erwägen, Wissen, Ethik (Deliberation-Knowledge - Ethics) Streitforum für Erwägungskultur 16 (2): 149-162, 219-234.

Fuchs-Kittowski, Klaus, Ursula Schuster and Bodo Wenzlaff. 1981. Working Environment Organizational, Technological and Social Problems of Computerization. Sotac'79 (Part I): Computers in Industry 2 (4): 275-285.

Fuchs-Kittowski, Klaus and Bodo Wenzlaff. 1987. Probleme der theoretischen und praktischen Beherrschung der modernen Informations- und Kommunikationstechnologien. Deutsche Zeitschrift für Philosophie 35 (6): 502-511.

Glansdorf, Peter and Ilya Prigogine. 1971. Thermodynamics Theory of Structure, Stability and Fluctuations. London: Wiley-Interscience.

Hartmann, Nikolai. 1935-1950. Ontologie. 4 Bände. Berlin: Walter de Gruyter.

Hauben, Ronda. 2004. Creating the Vision for the Internet, From the Wiener Circles to Licklider and ARPA's Information Processing Techniques Office (IPTO). In Kybernetik und Interdisziplinarität - Georg Klaus zum 90. Geburtstag, Abhandlungen der Leibniz-Sozietät, edited by Klaus Fuchs-Kittowski and Siegfried Piotrowski, 267-281. Berlin: trafo Verlag.

Hauben, Michael and Ronda Hauben. 1997. Netizens: On the History and Impact of Usenet and the Internet. Los Alamitos, NM: IEEE Computer Society Press.

Hofkirchner, Wolfgang. 2011. Emergent Information - A Unified Theory of Information Framework. Singapore: World Scientific.

Landwehr, Marvin, Alan Borning, and Volker Wulf. 2019. The High Cost of Free Services: Problem with Surveillance Capitalism and Possible Alternatives for IT Infrastructure. In LIMITS '19: Proceeding of the Fifth Workshop on Computing Within Limits, article 3. New York: ACM. https://doi.org/10.1145/3338103.3338106

Marx, Karl. 1857-1858. Grundrisse: Foundation of the Critique of Political Economy. London: Penguin.

Marx, Karl. 1844. On the Jewish Question. In Marx \& Engels Collected Works (MECW) Volume 3, 146-174. London: Lawrence \& Wishart.

Moravec, Hans. 1990. Mind Children: The Future of Robot and Human Intelligence. Cambridge, MA: Harvard University Press.

Müller-Hill, Benno. 1981. Die Philosophen und das Lebendige. Frankfurt am Main: Campus.

Numbers, L. Ronald. 2006. The Creationists: From Scientific Creationism to Intelligent Design. Berkeley: University of California Press.

Prigogine, llya and Isabelle Stengers. 1984. Order out of Chaos: Man's New Dialogue With Nature. Toronto: Bantam.

Teltschik, Horst. 2019. Russisches Roulette: Vom Kalten Krieg zum Kalten Frieden. München: C.H. Beck. 
Wahl, Dietrich. 2012. Sein und Selbst: Aus dem wissenschaftlichen Nachlass. Mit einem Essay von Klaus Fuchs-Kittowski: "Information und Selbstorganisation - Erkenntnis und Selbsterkenntnis". Berlin: Rosa-Luxemburg-Stiftung.

Weizenbaum, Joseph. 2001. Computermacht und Gesellschaft. Frankfurt am Main: Suhrkamp.

Weizenbaum, Joseph. 1976. Computer Power and Human Reason: From Judgement to Calculation. San Francisco: W.H. Freeman.

Zuboff, Shoshana. 2019. The Age of Surveillance Capitalism: The Fight for a Human Future at the New Frontier of Power. New York: Public Affairs Books.

\begin{abstract}
About the Author
Klaus Fuchs-Kittowski

Prof. Dr. Phil. Habil. Klaus Fuchs-Kittowski was a Professor of Information Processing at Humboldt University in Berlin. He was born December 31st 1934 in Berlin. He studied philosophy in Leipzig and undertook postgraduate training in biochemistry, biology, the mathematical foundations of cybernetics and philosophy of science at Humboldt University. He earned a PhD in philosophy on the problem of determinism and cybernetics in molecular biology. In 1964 he was among the founders of the University's Computer Center and, in 1968, of its Department of Economical Cybernetics and Operation Research, which later became the Department for Theory and Organization of Science. He was vice Director of the Department and Head of the Division of Information System Design and Automated Information Processing. In 1972, he was awarded the Rudolf Virchow Prize for medical research. He collaborated with the IIASAgroup on Modelling of Healthcare Systems and on Data-Communication. He became a member of IFIP/TC9 (International Federation of Information Processing, Technical Committee 9 Interaction of Computer and Society). For six years he was Chairman of the "Computer and Work" Working Group 1 of the IFIP/TC9. For this work, he received the IFIP Silver Core. In 1989, Fuchs-Kittowski had the opportunity of working on a project on Evolution of Information Structures led by Peter Fleissner at the Vienna University of Technology. Fuchs-Kittowski was Visiting Professor at the Department of Informatics at the University of Hamburg and Visiting Professor at the Department of Economical Informatics of the Johannes Kepler University in Linz. He currently teaches at the University of Applied Sciences (HTW) Berlin in the field of Environmental Informatics and Society.
\end{abstract}




\title{
Freedom, Distribution and Work from Home: Rereading Engels in the Time of the COVID-19-Pandemic
}

\author{
Saayan Chattopadhyay* and Sushmita Pandit** \\ *Baruipur College, Kolkata, India, saayanchattopadhyay@gmail.com \\ **Future Media School, Kolkata, India, sushmitapandit@gmail.com
}

\begin{abstract}
The aim of this paper is to understand the emerging practices of work from home drawing from the works of Friedrich Engels. Situating the rising debate on work from home, particularly in the context of the COVID-19 pandemic, this article revisits some of the texts by Friedrich Engels to understand the issues of distribution, freedom, necessity and work. The idea of work from home becomes especially critical in the context of a developing country like India, with its limited access to digital infrastructure, inadequate work-space at home, and precarious work conditions. However, the digital network and devices play a pivotal role under these conditions and often offer a promise of "new freedom" and flexibility. It is not just the middle-class professionals, but several other dimensions of work and labour are implicated within the idea of work from home under sudden economic and social disruption. The new organisation of production, assisted by capitalism, forges new relations of production, and new predicaments and Engels's thoughts on freedom, work and the condition of the working class become increasingly relevant to understand these shifts, particularly in neoliberal, developing country like India under nationwide lockdown.
\end{abstract}

Keywords: pandemic, work from home, Friedrich Engels, Karl Marx, freedom, migration, distribution, COVID-19, coronavirus

\section{Introduction}

The novel coronavirus or COVID-19 pandemic has created an unprecedented situation in almost every sphere. From the initial days of the pandemic, both developed and developing nations appeared to be particularly vulnerable and often inadequate in the fight against the virus. The impact has been considerably more complex and multifaceted in developing countries like India, Bangladesh, and Africa. The virus, explain Jean-Luc Nancy and Jean-François Bouthors (2020), by its novelty, its speed of transmission, the surprises it holds in store for us in terms of its modes of action on the organism, and above all, because many of the people it infects are asymptomatic carriers - places us in a situation of extreme uncertainty. It also demands a certain degree of interdependence that no country, however large and powerful, can save itself by its own efforts alone.

The virus seems to have an inherent class identity, as it was initially spread by individuals who have travelled internationally. Moreover, the first confirmed cases are largely in urban areas, among the affluent classes, and slowly spreading towards the rural territories and poor people. A news report mentions, "When it arrived in the unforgiving industrial towns of central Mexico, the sand-swept sprawl of northern Nigeria and the mazes of metal shanties in India's commercial capital, Mumbai, COVID-19 went by 
another name. People called it a 'rich man's disease'" (Bengali et al. 2020). Moreover, as Fuchs (2020) explains, in the coronavirus crisis, "the home has become the supra-locale of everyday life". The social spaces and locales of work, education, the public sphere, the private sphere all converge in in the locale of the home. Consequently, the allocation of time and the organization of everyday life has become exceedingly difficult for the overburdened individual juggling "multiple social roles at the same time in one locale" (379). Therefore, the pandemic problematises a number of issues under capitalism and the time seems ripe to look at how the deep-rooted problems of labour, value, class divisions, relations of production change with the mutations of capitalism. This article, however, limits its scope within the discussion of work from home during the pandemic and revisits some of the texts written by Friedrich Engels to understand how the notions of work, home, freedom and necessity reconfigure within a larger framework of understanding power and resistance in the Marxian tradition.

The analysis that follows starts from the assumption that "digital communication technologies have not transformed our society in a way that changes its underlying capitalist nature. Hence, we can and should analyze contemporary capitalism with established analytical and theoretical categories. The other is that digital communication technologies are implicated in a radical transformation in capitalism, one which requires us to re-evaluate, re-formulate, and update our Marxist categories to account for these transmutations" (Fuchs and Fisher 2020, 3).

In the first section, the article focuses on the emerging practices of work from home and the salaried middleclass or upwardly middleclass. Although work from home seems to be a beneficial policy for working professionals, there are some tenacious and entrenched questions that need to be addressed to critically understand what the conditions of the working class look like in the pandemic situation. Drawing from Engels's conceptualisation of distribution and the material conditions of existence, we argue that the primary problematic of work from home is the crisis of uneven distribution. The second section deals with the triumphant rhetoric of work from home that foregrounds the ideas of greater freedom and flexibility. Re-reading sections from Engels's Anti-Dühring (1878), the article questions freedom from what and freedom for whom. The paper shows that the employees working from home for information technology services or software firms, like any other workers, are not free, but being controlled "by the very object it should itself control" (Engels 1878, 106). Hence, the freedom that the software or IT professionals working from home enjoy is evidently negative freedom. The third section addresses the crisis of migrant workers and underlines the problem of the opposition between work and home for these labourers. We identify parallells with the antithesis between town and country that Engels was talking about in his series of articles on The Housing Question in 1872.

\section{Work from Home and the Precarious Salaried Middleclass}

The idea of work from home is largely discussed around the specific community of salaried middleclass or upwardly middleclass ${ }^{1}$. The prolonged lockdown and stay at home

1 Since these employees do not produce commodities but are largely engaged in managing, servicing and distributing on behalf of the owners of the businesses, they can be termed petty- 
mandate initiated varied types of work from home practices that continued for months. One of the first large companies to declare the provision of work from home until the middle of 2021 for its employees was Google. The parent company, Alphabet Inc. did not only extend the work from home (WFH) provision for its US employees but also extended the offer for its employees working in Google India, Brazil and UK (Copeland and Grant 2020). Twitter on the other hand, announced that their employees might consider working from home "forever". Similarly, Facebook also adopted WFH and claimed that they are planning to allow half of all employees to work from home by 2030 (Sandler 2020).

In India, which is considered to be one of the most sought-after countries for setting up an offshore development centre because of its cost-effectiveness and it holds around sixty-five percent of the outsourced IT jobs, most of the large information technology companies declared work from home policies with the spread of the pandemic. From April 2020 onwards, most of the information technology companies based in India started announcing their work from home policies (PTI 2020). Tata Consultancy Services (TCS) was one of the first Indian companies to announce work from home for its employees and claimed that within the next five years, seventy-five percent of its global employees would be permanently working from home (Khetrapal 2020). Subsequently, Infosys an Indian multinational corporation that offers information technology and outsourcing services announced that more than thirty percent of its employees would be permanently working from home even in post-COVID situation (ET 2020). As per newspaper reports, the top five IT companies in India, TCS, Infosys, HCL Tech, Wipro and Tech Mahindra together have over 1.1 million employees on their payrolls for the quarter ended June and a ninetyfive percent average would mean more than one million employees working from home (Srikanth 2020).

The IT sector is also witnessing some significant structural changes as well in response to the pandemic induced work from home. According to Hyderabad Software Enterprises Association (HYSEA) a number of start-ups and small and medium enterprises are already cancelling their lease contracts of office premises, as they are thinking about alternative modes of operations after the introduction of almost mandatory work from home during the COVID-19 pandemic. Since for most of the IT companies, thirty percent of the cost is establishment or office space, this new arrangement is supposed to be beneficial both ways (Maitreyi 2020). Similarly, the young IT professionals from other states who were staying in the city in shared accommodation are now terminating their rental contracts as they are continuing work from home from their home state (Aravind 2020).

While work from home sounds like a favourable option for a number of working professionals, there are some pressing and deep-rooted issues that need to be underlined to better understand the condition foregrounded by the pandemic situation. Fuchs (2014, chapter 8) in his case study of digital labour in India shows that the strategies of virtual migration and body shopping organise space in a racist manner for exploiting Indian labour in such a way that "it is highly exploited, individualized, dispersed, isolated, precarious, non-unionized and for cheapening labour-power so that the wage costs are low and profits can be maximized" (2014, 205). Moreover, since most of the IT companies are engaged in outsourced projects, the value produced by these companies

bourgeois. They may not always relate to the working-class consciousness since they are supposed to have some degree of control over the bourgeois apparatus. 
are ultimately "appropriated and owned by Western capital, which accumulates capital by selling software based on the dispossession of the value created by Indian software engineers in such a way that high exploitation rates are given" (211). While a number of studies have focused on this macro level exploitative structure of Indian software companies, let us now focus on the specific case of work from home.

\section{Distribution and the Material Conditions of Work from Home}

One of the major problems of working from home, especially in a developing country like India is the unequal access or distribution of equipment and services necessary for conducting work from home. It is important to mention that unequal access to or distribution of equipment and services does not only entail personal computers, webcams and smartphones but also such basic infrastructures such as uninterrupted electricity, access to clean water, separate room or space for a work-set up, availability of broadband connection". Friedrich Engels reminds us that "[...] with the differences in distribution, class differences emerge" and the division between the privileged and the dispossessed, the exploiters and the exploited, the rulers and the ruled are maintained so that the conditions of domination of the ruling class against the subjected class are perpetuated (Engels 1878, 136-137). Distribution, Engels emphasises, however, is not merely a passive result of production and exchange; it in its turn reacts upon both of these (Engels $1878,137)$. The primary problematic of work from home, we would argue, is the problem of unequal distribution, even among the salaried, urban middle class.

While at the beginning, there was an acute shortage of work from home equipment, soon rising consumption of such accessories, including furniture witnessed an exponential increase, mainly in the urban areas (Mishra 2020) ${ }^{3}$. However, it is pertinent to ask, who are able to buy these products and services? As pointed out by many reports, there are wide differences in the salary and other financial benefits among the salaried employees in India (GOI 2019). Excluding a few multinational companies, none of the organisations provided a separate laptop or other accessories and did not offer separate allowances for buying the appropriate furniture or for installing Internet routers. The claims for additional allowance to make up for the added electricity and Internet bills are often disused by the corporations, even in developed countries (Collinson 2020).

The sphere of the home itself posits difficulties for the software or IT worker. Following work from home policies, to a certain extent, the use-value of the "home" is enhanced as it becomes the site of production since use-value is generated only through use or consumption. However, a significant number of middleclass employees do not have a separate workspace. In fact, reports published during the pandemic point out that about forty-one percent of households in India have just one room or don't have a separate

${ }^{2}$ Distribution to a certain extent appears to be almost as a pre-economic component that precedes production. An individuals' position in the society is determined by distribution.

3 During the pandemic period, Amazon India's sale was marked as the single biggest two-day promotional event this year. Although initially online sales were down but soon sales of online retailers have exceeded pre-COVID-19 levels in terms of volume, mainly due to purchase of grocery and essential items. Personal computing, large appliances, and smartphones were the top-selling categories. Even at the highest number of infected populations, in US Amazon recorded biggest profit ever. The company said revenue increased forty percent from last year. Amazon's shares have increased by more than sixty percent in 2020. 
living room and often about five people share such accommodations (Jadhav 2020). About thirty-two percent of households, according to reports, have two room household, however, only forty-seven percent of households have access to water within the building premises and forty-two percent do not have the provision to take a shower inside their house (Jadhav 2020). These facts came into light not in the context of work from home, rather in reference to the Union Ministry of Health and Family Welfare, Government of India's guideline on home quarantine, which stated that one should "[s]tay in a wellventilated single-room preferably with an attached/separate toilet" (GOI 2020) Therefore, it becomes evident that when a substantial percentage of even the urban population in India is not in a position to follow the guideline on home quarantine, then how can we expect to have a suitable work from home facility for the majority of IT employees. Hence, this is a problem of distribution, not only distribution of goods and services, but also about the distribution of wealth, property, basic amenities, and household services ${ }^{5}$.

Distribution, explains Marx $(1857 / 1858,96)$ in Grundrisse, in general, means the distribution of products; it is thus "further removed from and made quasi-independent of production". However, he is quick to point out, before distribution becomes the distribution of products, it is firstly, the distribution of the means of production, and second, the distribution of particular individuals among specific types of productions, in other words, "the subsuming of the individuals under definite relations of production" (Marx 1857/1858, 96). Since production must proceed from a specific distribution of the means of production, distribution is to this extent antecedent to and a prerequisite of production. It is evident that those "distribution which is initially a factor of production" further invests in increased consumption, particularly in the context of work from home that in turn, provides impetus to the capitalist structure of production.

4 The idea of home quarantine was exceedingly difficult since a large number of people do not have essential amenities in the premise. Even in urban areas, thirty-six percent household do not have clean water source within 100 meters radius and in rural territory it increases to 500 meters.

${ }^{5}$ While all these elements seem economic, it is useful to remember what Engels wrote on the importance of economic element in the historical struggles in his letter to Joseph Bloch in 1895: "According to the materialist view of history, the determining factor in history is, in the final analysis, the production and reproduction of actual life. More than that was never maintained either by Marx or my- self. Now if someone distorts this by declaring the economic moment to be the only determining factor, he changes that proposition into a mean- ingless, abstract, ridiculous piece of jargon. The economic situation is the basis, but the various factors of the superstructure - political forms of the class struggle and its consequences, namely constitutions set up by the ruling class after a victorious battle, etc., forms of law and, the reflections of all these real struggles in the minds of the participants, i. e. political, philosophical and legal theories, religious views and the expansion of the same into dogmatic systems - all these factors also have a bearing on the course of the historical struggles of which, in many cases, they largely determine the form. It is in the interaction of all these factors and amidst an unending multitude of fortuities (i. e. of things and events whose intrinsic interconnections are so remote or so incapable of proof that we can regard them as non-existent and ignore them) that the economic trend ultimately asserts itself as something inevitable. Otherwise the application of the theory to any particular period of history would, after all, be easier than solving a simple equation of the first degree" (Engels 1890, 34-35). 


\section{Negative Freedom and The Mechanisms of Control}

Let us now come to the idea of freedom. The celebratory rhetoric of work from home often employs the ideas of greater freedom and flexibility. But it might be useful to question freedom from what and freedom for whom? Even in the context of the developed nationstates, a passing glance at the journalistic articles points to the inevitable struggles associated with working from home. One such article mentions,

An executive at JPMorgan Chase \& Co. gets unapologetic messages from colleagues on nights and weekends, including a notably demanding one on Easter Sunday. A web designer whose bedroom doubles as an office has to set the alarm to remind himself to eat during his non-stop workday. At Intel Corp., a vice president with four kids logs 13-hour days while attempting to juggle her parenting duties and her job[...] whatever boundaries remained between work and life have almost entirely disappeared (Davis and Green 2020).

A global survey conducted by one of the personal virtual private network service providers indicated that during the work from home period employees are working longer hours than usual. While the US increased their average workday by almost forty percent, Canada, France, Spain and the UK witnessed two hours increase each day (Meakin 2020) ${ }^{6}$.

In the context of developing nations, like India, where labour rules are historically lenient and often goes unreported and unmonitored, the picture is even grimmer.

At a top strategy consulting firm, a partner says he logs in for calls at 8am, and that continues till $10 \mathrm{pm}$ and sometimes beyond, as people schedule meetings irrespective of time zones and holidays. Another senior executive working out of a guest house in Bengaluru routinely ends up missing lunch during his non-stop workdays. Employees, some of whom are working till the wee hours of the morning, aren't getting me-time or family time; there are complaints of headaches and body aches, which again is leading to anxiety and depression because, given the current job situation, they feel they have no choice [...] Most are working much more despite salary deductions (Philip and Basu 2020) ${ }^{7}$.

${ }^{6}$ The human resource $(\mathrm{HR})$ departments of the corporations are also divided on this issue. While some of the think that employers need to draw a line. "They can't intrude into employee privacy and personal time", others believe that it is the employees' responsibility to be self-disciplined and create boundaries for working hours (Lijee and Basu 2020).

7 A few of the recognized entrepreneurs voiced their opinion to increase the work hours to compensate for the economic loss during COVID-19. For instance, Narayana Murthy, cofounder of Infosys in India said Indians must work for sixty hours a week for the coming twothree years to compensate for the coronavirus lockdown. Similarly, Jack Ma co-founder of Alibaba Group claimed that Chinese workers should work for twelve hours daily. However, none of them addressed the issue of improving working condition, over-time compensation and the complex impact of working hours increase on economy. 
The precarity of such work conditions was already existing and the COVID-19 pandemic has only augmented its impact. The conditions produced by the COVID-19 pandemic have foregrounded some of the basic questions posed by Engels and Marx.

While work from home often promises freedom for the individual, this freedom consists of a "dreamt-of independence" from the idea of being present in the office. As Engels explains in Anti-Dühring,

Freedom does not consist in any dreamt-of independence from natural laws, but in the knowledge of these laws, and in the possibility this gives of systematically making them work towards definite ends. This holds good in relation both to the laws of external nature and to those which govern the bodily and mental existence of men themselves - two classes of laws which we can separate from each other at most only in thought but not in reality (Engels 1878, 105).

Thus, the majority of the individuals being uncertain and more importantly ignorant of the oppressive structure seem to make an arbitrary choice among many different and conflicting possible decisions. This shows that "it [the individual] is not free, that it is controlled by the very object it should itself control" (Engels 1878, 106).

It is important to reiterate here that "freedom, therefore, consists in the control over ourselves and over external nature, a control founded on knowledge of natural necessity; it is therefore necessarily a product of historical development" (Engels 1878, 106). With this insight from Engels, we may move into the more established Marxist categories and state that the freedom that the software or IT professionals working from home enjoys is negative freedom.

Marx and Engels state that the history of bourgeois society shows an inclination towards offering abundant negative freedom. For instance, wage-labour, free trade lifts the various constraints on freedom of action and mark the characteristic bourgeois freedoms. However, both wage-labour and free trade expands the scope of profit for the capitalist and hence, "this negative bourgeois freedom is a kind of freedom which is real only for those who own the means of production" (MIA 2018). In contrast, positive freedom is gained historically through working-class struggle. Freedom gained through prolonged movements and protests, such as limiting labour time, public health systems, free compulsory education and right to unionise that in fact may pose constraints on the scope of profit for the capitalists. In that sense, bourgeois democracy, by its own structure does not allow, at least voluntarily, any positive freedom that the wage-workers may benefit from.

Then how do we understand this "new freedom"? Distinguishing disciplinary societies in the eighteenth and nineteenth centuries from the societies of control, Gilles Deleuze (1992) mentions in his short yet polemical essay that in disciplinary societies, the "individual never ceases passing from one closed environment to another"; individuals are trained or punished at various times in their by systems such as schools, the factory, the prison, or the family (Deleuze 1992, 3). On the contrary, societies of control - which emerged after World War II, are continuous in form and mark the present conditions of life. If the dominant model in disciplinary society was the factory, then in control societies, the dominant model is that of the "market". "Enclosures are molds, distinct castings, but controls are a modulation, like a self-deforming cast that will continuously change from one moment to the other, or like a sieve whose mesh will transmute from point to point" 
(Deleuze 1992, 5). Thus, the IT employee, who is working from home may find a "new freedom, but they could participate as well in mechanisms of control that are equal to the harshest of confinements" (Deleuze 1992, 4). While he is "free" to work from home, he is bound by a number of digital communication technologies that not only eat into his leisure time but also encroach his privacy and demands longer hours of engagement.

\section{The Antithesis Between Home and Work: Migration and The Social Question}

The idea of a safe home is not only confined to middleclass, salaried individuals. During the pandemic, a significant number of people from different occupations required the shelter of home. Here, it may be interesting to point out the massive migrant workers crisis in India that became the point of national debate and received much international attention.

In India, large and small companies, businesses and industries are significantly dependent on migrant workers. Unlike the developed nations, where migrant workers travel across national borders, in India, it is mainly internal migration, where labourers migrate from one state to another within the nation for work. These migrant workers are engaged in a number of different jobs, from construction work of new office buildings, cleaning and maintenance, to food supply, housekeeping and security. While workers engaged in software and IT companies usually means the white-collar worker, a large number of migrant workers are also part of digital capitalism, albeit almost invisibly. More visible counterparts are engaged in factories and particular production and manufacturing facilities.

On 24 March, 2020, the Government of India under Prime Minister Narendra Modi ordered a nationwide lockdown for 21 days, with four hours' notice. The declaration mandated a stay at home order for India's population of 1.3 billion: This was "the most severe step taken anywhere in the war against the coronavirus" (Gettleman and Schultz 2020). Several arrests across the states were made for violating norms of lockdown. The nationwide lockdown was extended thrice and continued till the end of May with conditional relaxations. ${ }^{8}$

During the nationwide lockdown, most of the migrant workers engaged in informal contract work were out of work since the offices, cafeterias, restaurants, and factories were closed for an indefinite period. A substantial number were evicted from their rented homes in which the labourers stayed in the city, as they were unable to pay the rent. With the rising COVID 19 cases, a number of state governments drove anxious, unemployed migrants into shelter homes. The unpreparedness of the state to tackle the sudden problem of large-scale homelessness because of the lack of work came to the forefront. First of all, there were very few shelters in response to more than 40 to 60 million stranded migrant workers. Second, most of the shelters or "safe homes" for the migrant workers are, in fact, "porta cabins: rectangular, non-sturdy, cargo-container-like structures. Most of them are designed to accommodate around 50 people to sleep comfortably. They are

${ }^{8}$ Since June 2020 onwards The MHA issued new guidelines stating that the phases of reopening would be targeted towards improving the economy. Lockdown restrictions were limited within the containment zones, and some other activities were gradually permitted in a phased manner. 
on average $800 \mathrm{sq} \mathrm{ft}$, which means each person gets about $15 \mathrm{sq} \mathrm{ft}$, about the area of a train berth" (Imaan 2020) ${ }^{9}$.

This dreadful combination of pandemic, unemployment, homelessness and hunger forced the workers to embark on homeward journeys of thousands of miles as all modes of transport were closed down due to lockdown. India had not witnessed anything like this mass migration across the plains of the country without food or a night's place of stay for sleep since the days of the Partition of the subcontinent (Samaddar 2020, II). While there is a lack of data but according to some estimates, more than three hundred migrant workers died on their way home. "Some died on the way due to illness, while others died in road accidents. Some died of exhaustion after walking home in the scorching heat" (Scroll 2020).

This incident foregrounds the idea of home or a "safe home" once again, particularly in relation to work in the context of COVID-19 pandemic in developing nations. It may be useful here to revisit the series of three articles by Engels originally published in Leipziger Volksstaat. These articles address an important debate articulated in Germany's democratic press, centred around the problem of housing shortage for the workers in major industrial centres. Now it is important to understand how the "housing question" is connected to "the social question". Engels posits the "kernel of the problem" as the antithesis of town and country. "The housing question can be solved only when society has been sufficiently transformed for a start to be made towards abolishing the antithesis between town and country, which has been brought to its extreme point by present-day capitalist society" (Engels 1872, 347). He asserts that the housing question cannot be solved without the abolition of the big cities, which is a corollary to the abolition of the capitalist mode of production. While he is aware of the utopian tone of such a statement but he states that it is "no more and no less utopian than the abolition of the antithesis between capitalists and wage workers" (Engels 1872, 384).

More than 2.5 million migrant workers who have come to Mumbai from other states like Uttar Pradesh, Bihar, Madhya Pradesh, West Bengal, Jharkhand and even far off states like Manipur, Assam and Mizoram craved to return home on Shramik Special trains (Workers' Special trains). The crisis brought forward the otherwise-invisible migrant workers' crisis and underlined the unavailability of the shelter for the migrant workers, the grim condition of the houses where they live in cramped up conditions and the unpreparedness of the state. However, as Engels explains in response to the housing question and the idea of "supplying each worker with a little house for his own possession":

Let us assume that in a given industrial area it has become the rule that each worker owns his own little house. In this case the working class of that area lives rent free; expenses for rent no longer enter into the value of its labor power. Every reduction in the cost of production of labor power, that is to say, every permanent price reduction in the worker's necessities of life is equivalent 'on the basis of the iron laws of political economy' to a reduction in the value of labor power and will therefore finally result in a corresponding fall in wages. Wages would fall on an

${ }^{9}$ One of the major missteps was to conflate the homeless and the migrant workers. As news reports mentioned many of the stranded migrants had never lived in homeless shelters, simply because they are not homeless. 
average corresponding to the average sum saved on rent, that is, the worker would pay rent for his own house, but not, as formerly, in money to the house owner, but in unpaid labor to the factory owner for whom he works. In this way, the savings of the worker invested in his little house would certainly become capital to some extent, but not capital for him, but for the capitalist employing him (Engels 1872, 345).

In today's context, Engels's quote underlines in what way the hue and cry about the shortage of labour shelter in Mumbai offsets the more pressing concern of why, for example, a worker from Mizoram needs to travel thousands of miles to Mumbai for finding work. And the same is also applicable for the software and IT professional working in Bangalore, Gurgaon or Noida, who has to rent a place thousand miles away from home. Hence, what Engels was trying to emphasise is that reforms policies cannot be the solution to problems that require revolutionary class politics in order to be solved. The widening gap between small towns and urban areas in India has witnessed a rising number of migrations from rural areas to the city. This reminds us the antithesis between town and country that Engels was talking about in 1872. "The abolition of the antithesis between town and country", Engels wrote, "from day to day it is becoming more and more a practical demand of both industrial and agricultural production" (Engels 1872, 384).

This antithesis becomes even more apparent as the migrant laborers, upon returning "home", are neither finding work nor adequate financial support from the government. As a substantial number of reports and articles reveal, a large number of migrants who have gone back to their home states are experiencing an acute shortage of work. For example, groups like Ghar Bachao, Ghar Banao Andolan (Save Home, Construct Home Movement) continuously received desperate calls from migrant workers, who are finding it hard to get any kind of employment in their home town and now desperately wants their job back in Mumbai or Delhi. "They have mortgaged their family's jewelry" a news report mentions, "and if they fail to find work, whatever little land they have, will be sold. Those who have returned are unable to even get access to universal PDS [Indian food security system], as their ration cards are back home" (Modak 2020).

While the government has increased funding for social security measures to ₹ 1 trillion, the highest ever since its inception in 2006, such measures cannot be a long-term solution, since with the increasing number of rural households applying for such schemes to make ends meet, "a household is unlikely to get more than fifty days of work on average, despite the higher funding" (Bera 2020).

Coming back to the antithesis that Engels pointed out: the problem, crudely put, is that where there is "home" there is no work and where there is work there is no "home". Interestingly, the agricultural sector, which is supposed to provide "work" in the rural areas has witnessed a steady "feminisation" over the years (Jiggins 1998). According to the Economic Survey 2017-18, with the increase in migration of men from rural to urban areas, the number of women in multiple roles such as cultivators, entrepreneurs and labourers is increasing, resulting in the "feminisation" of the agricultural sector (GOI 2018). As per the survey, women increasingly dominate all levels of the agricultural value chain, including pre-harvest, production, post-harvest processing, packaging, and 
marketing (Vasudeva 2018) ${ }^{10}$. Men who migrated to urban areas now consider agricultural work as "women's work" and find it difficult to adapt to the structural changes, even though the Indian economy remains predominantly an agricultural economy ${ }^{11}$.

\section{Conclusion}

Capitalist rule cannot allow itself the pleasure of creating epidemic diseases among the working class with impunity; the consequences fall back on it and the angel of death rages in its ranks as ruthlessly as in the ranks of the workers.

Engels $(1872,337)$ wrote these lines 148 years ago and now it becomes particularly relevant in understanding such categories of work, home and freedom and distribution in the context of the COVID-19 pandemic. As the novel Corona virus continues to make us confront unprecedented challenges, it is already reconfiguring our relationships to the nation-state, corporations, government, even to each other. Engels reminds us that the established structures of oppression and subjugation continue to exist, if not in a more aggressive manner, in most of the sectors during the pandemic. What the COVID-19 crisis has taught in the light of Friedrich Engels's thought is that it is necessary to consider the pandemic as a social question and not only as reforms related to health, economy and governance. The invisibility of certain kinds of labour and the everyday struggles associated with it has now come to the forefront. The pandemic also offered an entry point into the class politics of urban salaried middleclass, often employed within the networks of digital capitalism, and Engels's distinctively working-class outlook and political theory can be a valuable lens to explore it further.

\section{References}

Aravind, Indulekha. 2020. COVID impact: Professionals who can work from home are ditching the uncongenial cities. The Economic Times, July 13. Accessed August 25, 2020. https://economictimes.indiatimes.com/news/company/corporate-trends/safe-houseprofessionals-who-can-work-from-home-are-ditching-the-uncongenialcities/articleshow/76912728.cms

Bengali, Shashank, Kate Linthicum and Victoria Kim. 2020. How coronavirus - a 'rich man's disease' - infected the poor. Los Angeles Times, May 8. Accessed September 20, 2020. https://www.latimes.com/world-nation/story/2020-05-08/how-the-coronavirus-began-as-adisease-of-the-rich

10 Notably, as per Census 2011, out of total female main workers, fifty-five percent were agricultural labourers and twenty-four percent cultivators. However, little more than twelve percent of the operational holdings were owned by women, which revealed the gender inequality in ownership of landholdings in agriculture.

${ }^{11}$ However, we are not suggesting that migrant workers must revert back to being agricultural labourers. Since, Engels would not agree on maintaining the peasant as such. "Only as uniform a distribution as possible of the population over the whole country, only an integral connection between industrial and agricultural production together with the thereby necessary extension of the means of communication - presupposing the abolition of the capitalist mode of production - would be able to save the rural population from the isolation and stupor in which it has vegetated almost unchanged for thousands of years" (Engels 1872, 384). 
Bera, Sayantan. 2020. Citing lack of jobs back home, migrants eye a return to cities. Mint, 9 June. Accessed September 11, 2020. https://www.livemint.com/news/india/citing-lack-ofjobs-back-home-migrants-eye-a-return-to-cities-11591645708141.html

Collinson, Patrick. 2020. Should your employer pay your bills if you work from home? The Guardian, January 17. Accessed August 21, 2020.

https://www.theguardian.com/money/2020/jan/17/should-employer-pay-broadband-workinghome-cqc

Copeland, Rob and Peter Grant. 2020. Google to Keep Employees Home Until Summer 2021 Amid Coronavirus Pandemic. Wall Street Journal. July 27. Accessed August 4, 2020. https://www.wsj.com/articles/google-to-keep-employees-home-until-summer-2021-amidcoronavirus-pandemic-11595854201

Davis, Michelle F. and Jeff Green. 2020. Three Hours Longer, the Pandemic Workday Has Obliterated Work-Life Balance. Bloomberg, April 23. Accessed September 10, 2020. https://www.bloomberg.com/news/articles/2020-04-23/working-from-home-in-COVID-erameans-three-more-hours-on-the-job

Deleuze, Gilles. 1992. Postscript on the Societies of Control. October 59 (1992): 3-7. http://www.jstor.org/stable/778828

Engels, Friedrich. 1890. Engels to Joeph Bloch, 21/22 September. In Marx \& Engels Collected Works (MECW) Volume 49, 33-37. London: Lawrence \& Wishart.

Engels, Friedrich. 1878. Anti-Dühring. Herr Eugen Dühring's Revolution in Science. In Marx \& Engels Collected Works (MECW) Volume 25, 5-309. London: Lawrence \& Wishart.

Engels, Friedrich. 1872. The Housing Question. In Marx \& Engels Collected Works (MECW) Volume 23, 317-391. London: Lawrence \& Wishart.

ET. 2020. Keep Calm and Work from Home! Tech \& IT Giants That Are on WFH Mode till July 2021. The Economic Times, 25 August. Accessed September 17, 2020.

https://economictimes.indiatimes.com/magazines/panache/keep-calm-and-work-from-hometech-it-giants-that-are-on-wfh-mode-till-july-2021/embracing-the-newnormal/slideshow/77740411.cms

Fuchs, Christian. 2020. Everyday Life and Everyday Communication in Coronavirus Capitalism. tripleC: Communication, Capitalism and Critique 18 (1): 375-399.

https://doi.org/10.31269/triplec.v18i1.1167

Fuchs, Christian. 2014. Digital Labor and Karl Marx. New York: Routledge.

Fuchs, Christian and Eran Fisher. 2020. Reconsidering Value and Labour in the Digital Age. New York: Palgrave Macmillan.

Gettleman, Jeffrey and Kai Schultz. 2020. Modi Orders 3-Week Total Lockdown for All 1.3 Billion Indians. The New York Times, 24 March. Accessed September 9, 2020. https://www.nytimes.com/2020/03/24/world/asia/india-coronavirus-lockdown.html

GOI [Government of India]. 2020. Guidelines for home quarantine. Ministry of Health \& Family Welfare. Accessed September 9, 2020. https://www.mohfw.gov.in/pdf/Guidelinesforhomequarantine.pdf

GOI [Government of India]. 2019. Periodic Labour Force Survey (PLFS) 2017-2018. Ministry of Statistics and Programme Implementation. Accessed October 15, 2020. http://www.mospi.gov.in/sites/default/files/publication reports/Annual\%20Report\%2C\%20PL FS\%202017-18 31052019.pdf

GOI [Government of India]. 2018. Economic Survey 2017-2018. Ministry of Finance. Accessed September 9, 2020. http://mofapp.nic.in:8080/economicsurvey/

Imaan, Anhad. 2020. India's Migrant Crisis Pointed to Another Problem - Its lack of Shelter Homes. Scroll, 31 July. Accessed September 11, 2020. https://scroll.in/article/968374/indiasmigrant-crisis-pointed-to-another-problem-its-lack-of-shelter-homes 
Jadhav, Radheshyam. 2020. COVID-19: On Why Home Quarantine is Impossible for the Majority of Indians. The Hindu Business Line, 5 August. Accessed September 12, 2020. https://www.thehindubusinessline.com/news/COVID-19-on-why-home-quarantine-isimpossible-for-the-majority-of-indians/article32275067.ece

Jiggins, Janice. 1998. The Feminization of Agriculture. The Brown Journal of World Affairs 5 (2): 251-62. http://www.jstor.org/stable/24590325

Khetrapal, Sonal. 2020. Post-COVID, 75\% of 4.5 Lakh TCS Employees to Permanently Work From Home by '25; from 20\%. Business Today. 30 April 2020. Accessed August 13. https://www.businesstoday.in/current/corporate/post-coronavirus-75-percent-of-3-5-lakh-tcsemployees-permanently-work-from-home-up-from-20-percent/story/401981.html

Maitreyi, M.L. Melly. 2020. With WFH, New Dynamics at Play in IT ector. The Hindu, 14 June. Accessed August 25, 2020. https://www.thehindu.com/news/cities/Hyderabad/with-wfh-newdynamics-at-play-in-it-sector/article31828380.ece

Marx, Karl. 1867. Capital. Volume I. London: Penguin.

Marx, Karl. 1857/1858. Grundrisse: Foundations of the Critique of Political Economy. London: Penguin.

Meakin, Lucy. 2020. Working From Home Means Working Longer Hours for Many. Bloomberg, 23 March. Accessed September 9, 2020. https://www.bloomberg.com/news/articles/2020-0323/working-from-home-means-working-longer-hours-for-many-chart

MIA [Marxists Internet Archive]. 2018. Freedom. Marxists Internet Archive Encyclopedia. Accessed September 9, 2020. https://www.marxists.org/glossary/terms/f/r.htm

Mishra, Smriti. 2020. How \#wfh Has Benefitted Offline and Online Furniture Firms. Financial Express, 8 September. Accessed September 23, 2020.

https://www.financialexpress.com/brandwagon/how-wfh-has-benefitted-offline-and-onlinefurniture-firms/2077548/

Modak, Sadaf. 2020. Maharashtra: Migrant Workers Return to Scarce Jobs, Low Salaries. The Indian Express, 13 August. Accessed September 11, 2020. https://indianexpress.com/article/cities/mumbai/migrant-workers-return-to-scarce-jobs-lowsalaries-6552377/

Nancy, Jean-Luc and Jean-François Bouthors. 2020. Only Democracy Can Allow Us to Accept the Lack of Control Over Our History. Verso Blog. Accessed September 15, 2020.

https://www.versobooks.com/blogs/4772-only-democracy-can-allow-us-to-accept-the-lack-ofcontrol-over-our-history

Philip, Lijee and Sreeradha D Basu. 2020. Excessive Weight Gain, Longer Work Hours, Intrusion Into Weekends \& Holidays: Remote Working Comes With Side-Effects. The Economic Times, Jun 24. Accessed September 11, 2020.

https://economictimes.indiatimes.com/magazines/panache/excessive-weight-gain-longerwork-hours-intrusion-into-weekends-holidays-remote-working-comes-with-sideeffects/articleshow/76543675.cms

PTI. 2020. Government Extends Work From Home Norms for IT, ITes Companies till December 31. The Hindu, 22 July. Accessed August 13, 2020. https://www.thehindu.com/business/lndustry/government-extends-work-from-home-normsfor-it-ites-companies-till-december-31/article32155206.ece

Samaddar, Ranabir. 2020. Borders of an Epidemic: COVID-19 and Migrant Workers. Kolkata: Mahanirban Calcutta Research Group.

Sandler, Rachel. 2020. Half of Facebook's Employees May Permanently Work from Home By 2030, Zuckerberg Says. Forbes, 21 May. Accessed August 10, 2020. https://www.forbes.com/sites/rachelsandler/2020/05/21/half-of-facebooks-employees-maypermanently-work-from-home-by-2030-zuckerberg-says/ 
Scroll. 2020. Migrant Crisis: No Data on Deaths of Workers During Lockdown, 10.4 Crore Returned Home, Says Centre. Scroll, 31 July. Accessed September 10, 2020. https://scroll.in/latest/973074/migrant-crisis-no-data-on-deaths-of-workers-during-lockdown10-4-crore-returned-home-says-centre

Srikanth, Chandra R. 2020. More Than 10 Lakh Employees at TCS, Infosys, HCL, Wipro, Tech Mahindra Continue to Work From Home. Times Now, 28 July. Accessed August 25, 2020. https://www.timesnownews.com/business-economy/industry/article/more-than-10-lakhemployees-at-tcs-infosys-hcl-wipro-tech-mahindra-continue-to-work-from-home/628184

Vasudeva, Vikas. 2018. Farm sector sees 'feminisation', says Survey. The Hindu, 12 February. Accessed September 11, 2020. https://www.thehindu.com/business/farm-sector-seesfeminisation/article22564340.ece

\section{About the Authors}

Saayan Chattopadhyay

Saayan Chattopadhyay is an Assistant Professor and Head of the Department of Journalism and Mass Communication at Baruipur College, affiliated to the University of Calcutta, India. After a stint as a journalist, he is currently engaged in research involving digital media and society in India. He has published articles in Journalism Practice, Media Asia, South Asia Research, Studies in South Asian Film and Media, Journal of Boyhood Studies. He has also contributed chapters in books on media, gender and technology published from Oxford University Press, Palgrave Macmillan, Springer, Routledge, Lexington Books, Sussex Academic Press, among others. His research interests include media philosophy, cultures of mobility, South Asian masculinities, and techno-culture in developing countries.

\section{Sushmita Pandit}

Sushmita Pandit is an Assistant Professor of Media Studies at Future Media School, Maulana Abul Kalam Azad University of Technology, India. She also works as a radio presenter at All India Radio, Kolkata. She has published her works in journals such as Journalism Practice, Media Asia, Journal of Digital Media and Policy and Global Media Journal, among others. Her research interest includes digital humanities, television studies and media policy. 


\title{
The Conditions of the Global Digital Working Class: The Con- tinuing Relevance of Friedrich Engels to Theorising Platform Labour
}

\author{
Shahram Azhar \\ Bucknell University, Lewisburg, Pennsylvania, United States, \\ Shahram.azhar@Bucknell.edu
}

\begin{abstract}
This paper examines the conditions of the global digital class of platform labourers by drawing on the theoretical paradigm proposed by Engels in his pioneering contribution, The Conditions of the Working Class in England (CWC). Using a host of empirical sources surveys, oral narrations, medical and legal journals, and journalistic accounts - the paper develops a political-economic understanding of the working conditions of contemporary crowdworkers while paying close attention to the national and gendered disparities within them. Following Engels's dialectical mode of presentation in the CWC, the paper proposes a framework that contextualizes the lived experiences of crowdworkers in relation to: 1) the technological infrastructure of platforms, 2) emerging contractual and managerial modes of exploitation, 3) the gendered and racial articulation of labour extraction via Engels's notion of inter-worker competition, and 4) the macro dynamics of "surplus population" that push workers into precarious employment. The paper argues that the four qualitative attributes of capitalist labour identified in the CWC have experienced quantitative transformation under digital capitalism and at the core remain fundamental to a theoretical appreciation of the impact of digital capital on the lived experiences of the global digital working-class.
\end{abstract}

Keywords: digital labour, Friedrich Engels, political economy of the media and communication

\section{Introduction}

In a chilling investigative account of what he aptly terms the "The Trauma Floor", Newton (2019) describes terrifying details of the secret lives of Facebook content moderators. As a part of their daily labour regimen, they review hours of murder, hate speech, rape, and other forms of violent content for the leading social media website. In sharp divergence with the congenial imagery celebrated by the mainstream as making "Facebook the best place to work at" for its regular employees (Gillett 2017, 2 ), interviews with crowdworkers reveal a distinctly contrasting picture. These workers refer to their work as "mind-numbing", "stressful", "alienating", "precarious", and "micro-managed" and themselves as "bodies in seats" (Newton 2019, 24). Facebook's regular employees, on average, make $\$ 240,000$ per annum, enjoy premium health insurance, desirable retirement plans, and other perks. Crowdworkers for the same company, in contrast, survive on $\$ 28,800$ a year without any benefits. They are part of a concealed global workforce that is unable to meet "elementary subsistence requirements", is "constantly in search of work", and works at "odd hours of the day" (Berg et al. 2018, 13). They are, as Roberts $(2019,201)$ persuasively argues, the miserable others of "digital humanity".

Facebook is not the only global corporation benefitting from the misery of these workers. As a growing body of evidence from critical journalistic accounts, scholarly 
reports published by mental health professionals (Bourke and Craun 2014), legal experts (Cherry 2016), and labour surveys (Berg et al. 2018) reveal, digital giants such as Alphabet (Google and YouTube), Amazon, and numerous others are complicit in the exploitation of a concealed global workforce that experiences exploitation, jobinsecurity, unemployment, and severe mental health issues due to the precariousness of their contracts on the one hand, and the repulsive nature of their work on the other. In oral narratives, workers describe "telling dark jokes about committing suicide", "smoking weed during breaks to numb their emotions", and "having sex inside stairwells" in what one worker describes as "trauma bonding" (Newton 2019, 68).

Despite the 175 years that separate them, an analysis of these oral accounts reveals a haunting resonance with the debilitating working conditions chronicled by Friedrich Engels in his seminal work The Conditions of the Working-Class in England $(C W C)$ :

They are exposed to exciting changes of mental condition, the most violent vibrations between hope and fear; they are deprived of all enjoyments except that of sexual indulgence and drunkenness, are worked every day to the point of complete exhaustion of their mental and physical energies. And if they surmount all this, they fall victims to the want of work in a crisis (Engels 1845, 396).

In recent years, a number of scholarly contributions have posited digital labour as a new historical form of human activity (Fuchs and Sandoval 2014; Burston, DyerWitheford and Hearn 2010, Fuchs and Dyer-Witherford 2013, Fuchs and Sevignani 2013, Scholz 2012, Azhar 2020). In a series of contributions, Christian Fuchs (2007, 2013a, 2013b, 2014, 2015, 2017a, 2017b) elaborates concrete mechanisms via which the mode of capital accumulation on Internet-based platforms is premised, much like their industrial predecessors, on the exploitation of human labour. Scholars also point to the broader structural characteristics of the neoliberal economy - decades of austerity, inequality, and wage-repression - leading up to, and in the aftermath of, the Great Recession of 2007 that diminished the bargaining power of workers, pushed them to accept precarious forms of labour, and enabled new contractual forms of global accumulation (and its corollary, worker's exploitation) to emerge (Van Doorn 2017; Hill 2017; Mahmud 2012; Peck and Theodore 2012; Peck and Tickell 2002).

This paper lies in the same research trajectory and seeks to contribute to explorations in digital capitalism by proposing a political-economic framework that draws on the pioneering work of Engels to understand the working conditions of platform laborers. I rely on a host of sources including quantitative/qualitative surveys conducted by the ILO and other organizations across multiple countries, scholarly work published in medical and legal journals, and oral narrations of workers recorded in journalistic accounts. The paper argues that four qualitative attributes of working conditions identified in the CWC are crucial for a theoretical appreciation of the lived experiences of contemporary digital labourers:

1) the link between enabling technologies and emerging forms of contractual, managerial, and social relations of production;

2) the upscaling of global competition within the working-class; what Engels describes as inter-worker competition; 
3) a gendered and racial articulation of labour extraction that preys on the most helpless segments of the globe;

4) the broader attributes of the capitalist economy in the aftermath of the Great Recession that expanded the "surplus population", its ties with the bargaining power of labour, and how it facilitated the birth of new forms of control and command structures.

The CWC refers to these dimensions as "the characteristic features of the development of the capitalist mode of production" and its "inevitable consequences" for workers (Engels 1845, 372). Following the dialectical methodology proposed in Engels (1878), I argue that the aforementioned dimensions can be seen as qualitative attributes that have witnessed quantitative transformation since Engels's time. Thus, despite the spatial-temporal distance that separates industrial England from contemporary digital labour, the core features and outcomes remain strikingly similar to the framework proposed in the CWC.

The paper focuses on a narrow set of digital workers, specifically, the class of "crowdworkers": contingent workers that perform contractual "on-demand" labour on digital platforms such as Amazon Mechanical Turk (AMT), Clickworker, CrowdFlower, Microworkers etc. Crowdworkers are large groups of workers that are peculiar in a number of ways. They find and perform labour online, span multiple time zones, and essentially work on piece-rates; that is, they do not have contracts beyond the single task at hand. Their exploitation is concealed behind the legal facade of "selfemployment".

A focus on a subset of digital workers is justified on two grounds. First, as Fuchs and Sandoval (2014) point out, there is a multiplicity of possible forms of digital labour. To complicate comparative analyses further, the supply chains within which these differential forms are embedded may coexist alongside non-capitalist relations (Fuchs 2017a). Consequently, which forms fulfil the key characteristics of digitality is itself an open empirical/theoretical question, an answer to which depends on "various dimensions of work, such as the way people look for jobs and employment, employer's search for labour power, the relations of production, the technological means of production, the used resources, the created products, forms of distribution, and forms of consumption" (Fuchs and Sandoval 2014, 514). By focusing on a subset, we can fix the dimensions of employment-search, the managerial model (algorithmic management), the technological infrastructure, and the contractual relations within which the labour process occurs.

Second, focusing on a subset of digital labourers allows an analysis of both the similarities as well as the diversity within working conditions along gendered and national lines. A key concern for Engels in the CWC, an aspect to which he devotes an entire section of the book, is to unearth mechanisms via which fractures and competition within the working-class impacts general working conditions. Seen from this light, platforms are the "closest proxy to the idea of a global labour market where everyone competes for jobs regardless of location" (Beererpoot and Lambregts 2015, 236) and provide us with an ideal setting to re-examine Engels's key predictions.

The rest of the paper is structured as follows: section 2 briefly revisits four key theses from the CWC. Section 3 utilises this theoretical scheme to examine workingconditions on crowdplatforms using a host of empirical sources. Section 4 concludes with a discussion of the implications of revisiting the CWC for critical theory and praxis in the digital world. 


\section{Theoretical: CWC as a General Theory of Capitalist Working Conditions}

I am up to my eyebrows in English newspapers and books upon which I am drawing for my book on the condition of the English proletarians. I shall be presenting the English with a fine bill of indictment; I accuse the English bourgeoisie before the entire world of murder, robbery, and other crimes on a massive scale $[\ldots]$ That'll give those fellows something to remember me by (Engels 1844,10$)$

This section briefly revisits the CWC as a theory of working conditions under capitalist relations of production; specifically, as a framework that ties the technological infrastructure in any capitalist setting to a theory of the lived experiences of the working population that sustains it. Engels connects technical innovations to specific contractual and managerial modes of exploitation, delineates the gendered and racial articulation of labour extraction via the concept of inter-worker competition, and also examines the dynamics of "surplus population" that propel workers to participate in precarious labour. In the next section, we will use this framework along with recent extensions by Fuchs and Sandoval (2014) to contextualise empirical accounts of crowdworkers.

\subsection{Technology, Competition, and Social Relations}

The consequences of improvements in machinery under our present social conditions are, for the workingman, solely injurious, and often in the highest degree oppressive (Engels 1845, 433)

The CWC presents distinct channels via which technological developments, fettered by capitalist social relations, adversely impact the conditions of a given working population by:

1) expanding inter-worker competition, that is, by transforming the scale at which workers compete against one another;

2) giving birth to unique contractual and managerial bonds that disguise the dichotomy between paid/unpaid labour via the facade of legality;

3 ) deskilling workers due to task monotony and the constant threat of being pushed into the ranks of the unemployed, what Engels terms a "surplus population" (Engels 1845,566 ). Each of these factors will be clearly observed in the oral narrations of crowdworkers in section 3.

\subsubsection{Inter-Worker Competition}

A key prediction in the CWC is that an expansion in the global labour market will exert a downward pressure on wages by enhancing inter-worker competition. "Competition", Engels argues, "is the completest expression of the battle of all against all which rules in modern civil society" (Engels 1845, 375). It as a "battle for life" that is "fought not only between different classes of society alone but also within the individual members of these classes" (375). Thus, the scale of inter-worker competition determines the "minimum of wages" and the concept is central to any account of working conditions (375). 


\subsubsection{Labour Contracts and Managerial Relations}

Another qualitative attribute of the CWC is to theorise the technological apparatus in any capitalist setting in relation to the contractual and managerial relations that it engenders. Engels argues that these juridical relations are pivotal to an understanding of working-conditions as they determine the precise manner "in which the bourgeoisie holds the proletariat chained" (467). The domain of the contract, he argues, is where "ends all freedom in law and in fact" (467). This will be an important theme when trying to understand the legal underpinnings of crowdworkers' struggles against digital capitalists in the next section. As we will see, the platform-owner is akin to "the "absolute law-giver"; he makes "regulations at will, changes and adds to his codex at pleasure, and even, if he inserts the craziest stuff, the courts say to the working-man: "You were your own master, no one forced you to agree to such a contract!" (467).

\subsubsection{Surplus-Population and Worker's Bargaining Power}

Engels also pays close attention to the role of technological change in determining the unemployment rate and the bargaining power of labour. His analysis points to the structural attributes of the capitalist economy at any given point and how these, in turn, propel workers to pursue precarious labour: "anarchy of production", "period crises", "deepening of class antagonisms", and "the formation and growth of a reserve army of labour and chronic unemployment" (Engels 1845, 444-452).

\subsection{Nationality and Gender}

In addition to theorising the technological infrastructure in relation to working conditions, the CWC is one of the first scholarly attempts to theorize the disparities within the conditions of the working class along the lines of nationality and gender. This includes an analysis of identity-based sectoral employment and the net impact of these differences, in turn, on aggregate working-conditions.

Technical innovations of the industrial era had already begun to incorporate "the vast masses who now fill the whole of the British Empire" (Engels 1845, 351). Prior to this, the "crushing power of competition that came later with the conquest of foreign markets and the extension of trade did not yet press upon wages" (351). At the global scale therefore, Engels argues, the internal transformations in Western capitalism and their impact on the working-class need to be seen in their interconnectivity with the periphery, the broader colonization movement at the time (Magubane 1985).

Engels devotes a section to "Irish immigration" to understand variations in relative depravity across nationalities. "The Irish", Engels argues, "had nothing to lose at home, and much to gain in England" (Engels 1845, 388). They were willing to accept the "minimum of the necessities of life" (390). British capitalists benefitted enormously from the "impoverished population of Ireland", which acted as "a reserve army at their command" (389). Engels's prediction is that the scale of international interworker competition is inversely related to working conditions, as it allows capitalists to extract maximum surpluses by targeting the most helpless sections. A befitting confirmation of this prediction will be seen in the next section when considering how crowdplatforms use programmed filters to target particular sections of the global working-class. This will be crucial to appreciating wage-differentials between crowdworkers in the global North versus third-world countries.

Finally, a consistent theme in the CWC is the gendered articulation of capitalist exploitation. Engels points out that the wage-differential along gendered lines is also intricately tied to the concept of inter-worker competition. On the one hand, techno- 
logical changes allow capitalists to replace male workers with female workers. But the exploitation of women, Engels points out, takes an even more "inhumane form" owing to the additional burden of child-care. The exploitation of both parents "at once breaks up the family"; the children "grow like wild weeds" (Engels 1845, 436) bringing the most "demoralizing consequences for parents as well as children" (437). As we will see, many female crowdworkers will point to their care responsibilities as a dominating factor effecting their working conditions.

\section{The "Others" of Digital Labour: Class, Gender, and National Exploitation on Crowdwork Platforms}

We now turn our attention to contemporary crowdworkers and ask whether or not, and to what extent, their experiences bear "the characteristic features of capitalism" and its "inevitable consequences" (Engels 1845, 355). Following Engels's mode of presentation in the CWC, I begin by describing the technological infrastructure (crowd-platforms) and how it enables a new managerial and contractual labourextraction model. We then turn to the dichotomy of paid and unpaid work on platform technologies, the national and gendered variation across the experiences of crowdworkers, and finally the conceptual framework of "surplus population" as an explanatory tool for why workers engage in crowdlabour despite the precariousness that it offers. At each stage, worker's oral narratives are carved into the theory to demonstrate the experiential validity of Engels's predictions. To do this, we will rely on two broad sources of information:

1. Survey data collected by the ILO and other organisations across multiple countries in two recent surveys (2017 and 2015)

2. Qualitative information from oral narrations of workers and scholarly accounts published in legal and medical studies.

\subsection{Crowdplatforms: Algorithmic Management and Concealed Exploitation}

"It's a precarious employment situation as you're entirely at the mercy of the crowdwork platform" - Worker on the platform CrowdFlower, United Kingdom (Berg et al. 2018, 73)

"This is obviously a way of working that will likely explode in the future" Worker on the platform Amazon Mechanical Turk, United States (Berg et al. 2018, 1)

The birth of the Internet led to the emergence of a unique labour process that could be performed on a new technological infrastructure, the crowd-platform, via which capitalists engage in a transitory, piecewise, and anonymous relationship with a geographically segregated global workforce that is, quite revealingly, referred to as the "crowd". Value creation revolves around a platform-mediated online interaction between crowdworkers and service-requestors, where the latter "advertise tasks to large numbers of potential workers" and then use the platform to "retrieve and evaluate the results of completed tasks" (Berg et al. 2018, 11). The anonymity and transitory nature of the relationship offers capitalists the ability to control a contingent workforce with the additional facility of disguising exploitation using layers of contractual legalities. Mainstream theorists describe a platform as a "business that connects external producers and consumers and enables value-creating interactions between them" (Choudary 2018, 1). Seen from this light, the platform is nothing more than an 
intermediary between a producer and a consumer, rather than a power arrangement between a capitalist and an employee.

But a more nuanced political-economic understanding of the links between the mode of accumulation, corresponding relations of production, and working-conditions can be developed by paying closer attention to the labour-control mechanism. As the CWC explains, technological developments are fettered by capitalist relations and must be seen as institutions of monitoring and control. The unique attribute of crowdplatforms, from the capitalist standpoint, is not their ability to facilitate interactions but rather to create a governance model where capital can control workers while concealing labour exploitation.

Fuchs and Sandoval (2014) extend Engels's framework by presenting a convenient classification scheme that can be used to analyse working conditions under any capitalist production process. Using Marx's circuits of capital approach (Marx 1867), they present a model that delineates five distinct factors jointly shaping working conditions throughout any capital accumulation process.

$$
M<\underset{L P}{M O P} \cdots P-\mathrm{C}^{\prime}-\mathrm{M}^{\prime}
$$

The circuit describes the different "moments" of capital accumulation; at the first stage, the initial $M$ is spent on the commodities necessary for production: means of production (MOP) and labour-power (L). In the second stage, it enters the sphere of production $(P)$ where these commodities are productively consumed, giving birth to a new commodity ( $\left.C^{\prime}\right)$ that is pregnant with surplus-value. In the final phase, this surplus-value is realized with the sale of the commodity and its reconversion to the money form (M').

Seen from this light, the platform is the institutional and infrastructural arrangement that sets the conditions for production, exchange, and the remuneration of labour-power. It is at once the site of productive labour processes (the moment $P$ ), the mode via which workers exchange their labour-power for money $(L-M)$, and the unique managerial model that adjudicates whether the output $\left(C^{\prime}\right)$ is acceptable to the service-requestor or not.

A key attribute of the technology is the manner in which it arbitrates disputes between the task-requestor and the worker: "algorithmic management". In essence, workers are supervised by an algorithm that controls the labour process, the worker's output, and the piece-rate remuneration. In contrast to the claims by corporations that the method ensures "neutrality", the algorithm is actually designed to punish the slightest of errors on the part of workers.

This fact is borne out clearly in worker's accounts. For example, McInnis et al. (2016) who study the platform used by Amazon - Amazon Mechanical Turk - find that the number one complaint by crowdworkers is "work rejection" (Mclnnis et al. 2016, 2271). "Unfair rejections", workers explain, "can result from poorly designated tasks, unclear instructions, technical errors, and malicious requestors" (2271). Algorithmic management implies that "dispute resolution between workers and employers becomes intractable" (Irani 2013, 614) since there is no way workers can dispute the decision of the algorithm.

The algorithm is pre-programmed in a way that the service-requestor has the final word in every dispute. As Irani $(2015,228)$ explains, "Amazon does not require requestors to respond and many do not". Consequently, workers never know the rea- 
son why their work has been rejected. This explains why 90 percent of workers in ILO surveys "have had work rejected or have had payment refused" without recourse or right to appeal (Berg et al. 2018, 74). As a worker aptly explains, "if a requestor decides to reject your work, there is no way to contest this and have them make a fair ruling" (76). Another crowdworker for the platform Prolific explained that "you can be fired without notice, reason, or appeal" (82).

Engels's notion of the contractual bond, as a force that legalises misery, is vividly observed in workers' accounts. Before accepting a task, workers must agree to certain terms and conditions. As a rule, most platform owners make workers accept the status of an "independent contractor". For example, the conditions set by Amazon clearly state that "workers perform tasks for requesters in their personal capacity as an independent contractor and not as an employee of a requestor or Amazon Mechanical Turk" (Amazon Mechanical Turk 2017). Inequality is coded into law; the terms make it absolutely clear that crowdworkers "are not entitled to any of the benefits that a Requestor or Amazon may make available to its employees, such as vacation pay, sick leave, and insurance programs". Most crucially, workers are not "eligible to recover worker's compensation benefits in the event of injury" (Amazon Mechanical Turk 2017). Other platforms, such as Prolific, do not even classify them as workers of any kind, instead describing them as "participants" in research projects who receive "rewards" rather than payment for work performed (Prolific 2020).

As Engels would expect, the managerial and contractual model has been the subject of intense legal battles between workers and capitalists. Cherry (2016) conducts a comprehensive survey of recent disputes and their implications for labour regulations in the digital age. As her analysis reveals, disputes largely revolve around the contractual misclassification of workers. Despite the optimistic claims of celebrants, who brush aside the issue beneath the ideological facade of the "sharing economy", these legal battles reveal a close proximity to Engels's predictions. As Cherry (2016, $570)$ argues, "the new crowdwork seems a throwback to the de-skilled industrial processes" but "without the loyalty and job security". For example, in one class action lawsuit, Otey vs CrowdFlower, platform owners contended that since workers had contractually agreed to the terms of "self-employment", they did not have the right to demand a minimum wage (Cherry 2016). In another lawsuit, filed against Microsoft by Soto and Blauert, workers complained that the terms and conditions "did not prepare them for the stress of the job, nor did it offer adequate counselling and other measures to mitigate the psychological harm" (Cherry 2016, 566).

\subsection{Paid, Unpaid Labour, and the Delusion of Flexibility}

Crowdwork platforms advertise their tasks by promising flexibility and autonomy with regard to the "amount of work, the work schedule, and the location" (Berg et al. 2018, 49). An alternative reality, however, is revealed in worker's narrations who complain that their work is micromanaged, underpaid, monotonous, and alienating. As one Serbian worker for the platform CrowdFlower put it "a worker doesn't have much rights; very little if any worker protection, because everything is organized for the interest of the people that are hiring us" (Berg et al. 2018, 59).

Crowd-platforms allow capitalists to undercut domestic minimum wage regulations and prey on the most helpless sections of any country. This fact is borne out most visibly in ILO surveys, which distinguish between time spent doing paid work (i.e. actual work tasks that the crowdworker was paid for) versus the time spent doing unpaid work (i.e. looking for tasks, earning qualifications, unpaid/rejected tasks). The data reveals that a crowdworker spends " 24.5 hours doing crowdwork, of which 18.6 
hours are paid work and 6.2 hours unpaid" (Berg et al. 2018, 67). In other words, every hour of paid work implies that a third of additional time must be spent performing unpaid tasks. On average, "a worker earned $\$ 4.43$ per hour when only paid work is considered, and if total paid and unpaid hours are considered, then the average earnings drop to $\$ 3.31 "$ (Berg et al. 2018, 49). In another quantitative study, Hara et al. (2018) conduct a task-level analysis of 2676 workers performing 3.8 million tasks for Amazon and find that on average their crowdworkers earn approximately $\$ 2 /$ hour and only a tiny proportion, roughly $4 \%$, earn the minimum wage $\$ 7.25 /$ hour.

Moreover, across all 75 countries surveyed by the ILO, an overwhelming number of workers earn below their national minimum wage. For example, in 2017 on Amazon Mechanical Turk, roughly 48 percent of American workers earned less than the federal minimum wage (\$7.25) when only paid work is considered, and these proportions increase to 64 percent when unpaid work is taken into account (Ibid; 50). As one worker for AMT aptly pointed out: "a bare minimum of 10 cents a minute is barely acceptable, but anything under that is just greed" (Berg et al. 2018, 56).

As Engels would expect, the subhuman remuneration of these workers is intricately tied to their poverty. On average, $20 \%$ of crowdworkers surveyed by the ILO live in a household that cannot meet its basic subsistence requirements. The percentage of workers from a household that has insufficient savings to cover an emergency equal to one months' income is even larger, at 42 percent (Berg et al. 2018, 59). 44 percent of households "have debts such as student loans, car payments, medical or legal bills, or loans from relatives" (59). Moreover, the illusion of "flexibility" immediately appears as a facade when considering that a fifth of the workers surveyed by the ILO in 2017 reported that "they had current physical or mental health conditions lasting 12 months or more" (39). Quite significantly, 54 percent of these workers reported that their health problems affect the "kind of paid work they might do" (39).

Yet, unless covered by another job, most crowdworkers surveyed by the ILO did not have access to social security benefits: barely 40 percent had access to health insurance, less than "35 percent had a pension or retirement plan, merely 37 percent benefitted from some form of social insurance", and less than a third of the workers received government assistance (Berg et al. 2018, 60). As Engels's notion of the inverse link between a worker's bargaining power and remuneration would predict, Table 1 reveals that social protection coverage is inversely related to an individual's dependence on crowdwork; only 16 percent of the workers for whom "crowdwork is the main source of income were covered by a retirement plan, compared to $44 \%$ of those for whom crowdwork was not the main source of income" (60).

\begin{tabular}{|l|l|l|}
\hline Type of Social Protection & $\begin{array}{l}\text { \% when crowdwork is the } \\
\text { primary income source }\end{array}$ & $\begin{array}{l}\text { \% when crowdwork is the } \\
\text { secondary income source }\end{array}$ \\
\hline Health Insurance & 52.1 & 65.6 \\
\hline Pension/Retirement plan & 15.6 & 44.2 \\
\hline Unemployment & 9.7 & 19.1 \\
\hline Employment injury & 15.5 & 23.1 \\
\hline Disability Benefits & 11.2 & 14.5 \\
\hline
\end{tabular}

Table 1: Social Protection and Reliance on Crowdwork (Source: Berg et al. 2018) 


\subsection{National and Gendered Differences}

"Work should not be racial. It should be distributed equally in all the places rather than distributing it on the basis of country" - Worker on Microworkers, Nepal (Berg et al. 2018, 64)

"I have three children and don't have the means for a babysitter" - Worker on Microworkers, United States (Berg et al. 2018, 69)

Mainstream accounts often posit crowd labour as a unique opportunity for third-world economies and housewives to make money in otherwise stagnant economies (Nickerson 2014; Schriner and Oerther 2014); as a "silver bullet" for development that provides the "best hope for providing employment" that "leverages the natural, inherent incentives embodied in capitalism" (Schriner and Oerther 2014, 224). Yet, the experiential reality of the global digital working-class reveals a sharply contrasting picture.

As pointed out earlier, a key attribute of the platform is the creation of a global online labour market (Beerepoot and Lambregts 2014). This offers capitalists the unique opportunity of accessing the most helpless sections of the global workforce through the use of filters. Most platforms allow "clients to choose whether the tasks will be done by the global pool of labour or by a specific population based on certain characteristics, such as geographic location, earned qualifications, or other filtering criteria" (Berg et al. 2018, 63). Table 2, which compares the average compensation of workers in the USA and India across the same platform, Amazon Mechanical Turk (AMT), reveals that the average compensation for an AMT USA worker is two and a half times that of an Indian worker.

\begin{tabular}{|l|l|l|l|}
\hline Platform & Survey Year & $\begin{array}{l}\text { Compensation } \\
(\$ / \text { hour of paid } \\
\text { work) }\end{array}$ & $\begin{array}{l}\text { Compensation } \text { (\$/hour of } \\
\text { paid and unpaid work) }\end{array}$ \\
\hline AMT USA & 2017 & 8.51 & 6.54 \\
\hline AMT India & 2017 & 3.40 & 2.53 \\
\hline AMT USA & 2015 & 7.56 & 5.56 \\
\hline AMT India & 2015 & 3.95 & 2.95 \\
\hline
\end{tabular}

Table 2: Compensation across Nationalities (Source: Berg et al. 2018)

As Engels argued in the CWC, the greater the scale at which workers compete against one another, the lower will be the standard of overall wages and the differential within the working-class. The ILO survey befittingly confirms this prediction when it finds that in the "global competition for tasks on online platforms, the rivalry between American or European workers and workers in developing countries for the same tasks leads to a lowering of the equilibrium price for tasks" (Berg et al. 2018, 52). Workers in North America (US \$4.7) and Europe (\$3) earned significantly more than workers in Africa (US \$1.33) and Asia Pacific (US \$2.22). The share of crowdworkers living in poverty is "particularly high among crowdworkers in Africa (42 per cent), Asia (24 percent), and Latin America (23 percent)" (58) and lower in North America and Europe (17 per cent). Barely a fifth of crowdworkers from Africa and a third of workers from Asia had access to social benefits. The weakness of public social protection in these regions, in turn, implies that platform operators have "an additional incentive to undertake tasks using the pool of labour from these countries" as 
they face "less pressure from workers and governments to ensure social protection for platform workers" (61).

Moreover, national differences not only explain wage disparities but also the sectoral spread of the tasks assigned to workers from different nationalities. The tendency of increasing inter-worker competition identified by Engels is "reinforced by platforms that allow tasks to be targeted to specific groups of workers according to specific criteria, including country of residence" (Berg et al. 2018, 54). The tasks that are best-paid, such as "content-creation, editing, and content writing are often available only to American workers" (54). As Martin et al. $(2014,225)$ demonstrate in their ethnomethodological study of AMT workers, the crowd-platform labour market is akin to a "dual-banded labour marketplace" with national wage differentials programmed into the logic of the relation of production. Understandably, workers in the periphery have an acute awareness of this systemic bias. As a crowdworker for the platform Prolific in India pointed out, "just because someone is desperate enough to do these jobs doesn't mean that you will literally pay them peanuts" (Berg et al. 2018, 56).

Quantitative studies also reveal sharp discrimination along the lines of gender. As Engels would expect, there are major differences between the care-giving responsibilities between men and women and this directly impacts the working-conditions of female crowdworkers. In the ILO surveys, women were thrice as likely as men to report that the primary reason why they engaged in this work was because they could "only work from home" (Berg et al. 2018, 38). As one female worker narrates, "traditional workplaces are not compatible with my current needs" (39). A fifth of the female workers surveyed by the ILO had small children (69). These women spend "on average about 19.7 hours working on platforms in a week"; 36 percent of these work at night (10 p.m. to 5 a.m.) due to child-care responsibilities, and 65 percent during the evening (6 p.m. to 10 p.m.). Yet, "accounting for unpaid work, women's average pay was between 18 and 35 percent less than that of men" (52).

\subsection{Deskilling, Alienation, and Monotony}

"In the beginning, I had hoped that I would also get some higher quality type of work [...] But that doesn't happen. It is usually very simple, basic work. It is not really what I expected" - Worker for the platform Clickworker (Berg et al. 2018, 97).

"Crowdwork kept me from being homeless, but it's also a curse" - Worker for AMT India (Berg et al. 2018, 83)

In the CWC, Engels posits an intricate tie between capitalist accumulation and worker's alienation due to the deskilling effect of task-monotony. As far as capital is concerned, Engels argued, "if the monotony of an occupation makes you better suited for that occupation, then monotony is a productive force" (Engels 1845, 285). Consequently, "the worker's activity is reduced to some paltry, purely mechanical manipulation, repeated minute after minute" (415). Oral narrations of crowdworkers provide a befitting confirmation of this prediction as well. Across a range of quantitative and qualitative studies, crowdworkers describe their work as "frequently repetitive", "boring", and "mind-numbing". As one CrowdFlower worker put it, "It's not the type of job that requires many skills [...] besides knowing English" (Berg et al. 2018, 82). Another crowdworker from Germany, when asked for the reasons for her dissatisfaction, responded that "the work in itself is boring and physically tiring" (45). 
While crowdworkers are generally well-educated, the repetitive and mundane nature of the tasks that they perform leads to severe underemployment and deskilling. The ILO found "no relation between the educational level and the type of task performed" (83). The most common tasks performed by workers were content access (46 percent), data collection (35 percent), responding to surveys and experiments (65 percent), and transcription (32 percent). These tasks "include creating fake user accounts on websites, clicking through pictures, or watching and liking/sharing a video" (85). As one AMT worker put it, "it's a mind-numbing form of work" (96).

Content moderation, a major category of work, is particularly important for social media websites such as Facebook and YouTube that allow users to upload content. These tasks are often outsourced to crowdworkers, particularly in developing countries such as India and Philippines, who suffer from severe psychological trauma as a result of moderating repulsive content on repeat. Despite being well-educated, content moderators typically spend their days looking at content "” (Roberts 2016). As one former Facebook moderator succinctly explains: "Think like that there is a sewer channel and all of the dirt/waste/s*** of the world flows towards you and you have to clean it" (Chen 2017, 8).

The quantum of work performed is also quite significant, "as many as 8000 posts a day, rife with hate speech, videos of sexual exploitation, and violence" (Chen 2017, 8). As Engels would expect, the traumatic labour process takes a vicious toll on the mental health of crowdworkers. A study conducted by medical experts of the U.S Marshals Service, reported that a quarter of people in their sample "displayed symptoms of traumatic stress disorder" with frequent symptoms such as "insomnia, nightmares, anxiety, or hallucinations" (Bourke and Craun 2014, 587).

\section{5. "Surplus Population": Macro Reasons for Undertaking Crowdwork}

As Engels reminds us in the CWC, the individual experiences of workers are embedded within the overall state of the capitalist economy at any point in time, specifically the unemployment rate. True, digital technologies made it feasible to organize labour processes of business models around crowdwork. But it is equally crucial to appreciate the reasons workers give in oral narrations for why they undertake crowdwork, despite the precariousness and volatility that it offers.

The "on-demand" business model would be inconceivable without the large "surplus population" that was released in the labour market via under- and unemployment in the aftermath of the global collapse of capitalism, that is, the Great Recession in 2007/08. (Hill 2017; Van Doorn 2017). The crisis itself, however, was a product of the decades of neoliberalism that preceded it. The historical stage was set by a host of reforms that resulted in a rapid decline in the organizational power of labour. As Peck and Theodore $(2012,742)$ point out, this allowed "temporary staffing agencies" to emerge as an industry in its own right, restructure "workforce systems and rewrite the social contract" governing employment so that employers could "download the risks inherent in a volatile economy and to offload the responsibilities that historically have been associated with the standard employment relationship" (742).

Engels's notion of "surplus population" is aptly reflected in oral narrations. In an overwhelming number of cases, unemployment immediately precedes crowdwork. As the figure below reveals, prior to working as crowdworkers $55 \%$ of workers had been working as regular employees and over $30 \%$ were unemployed. 


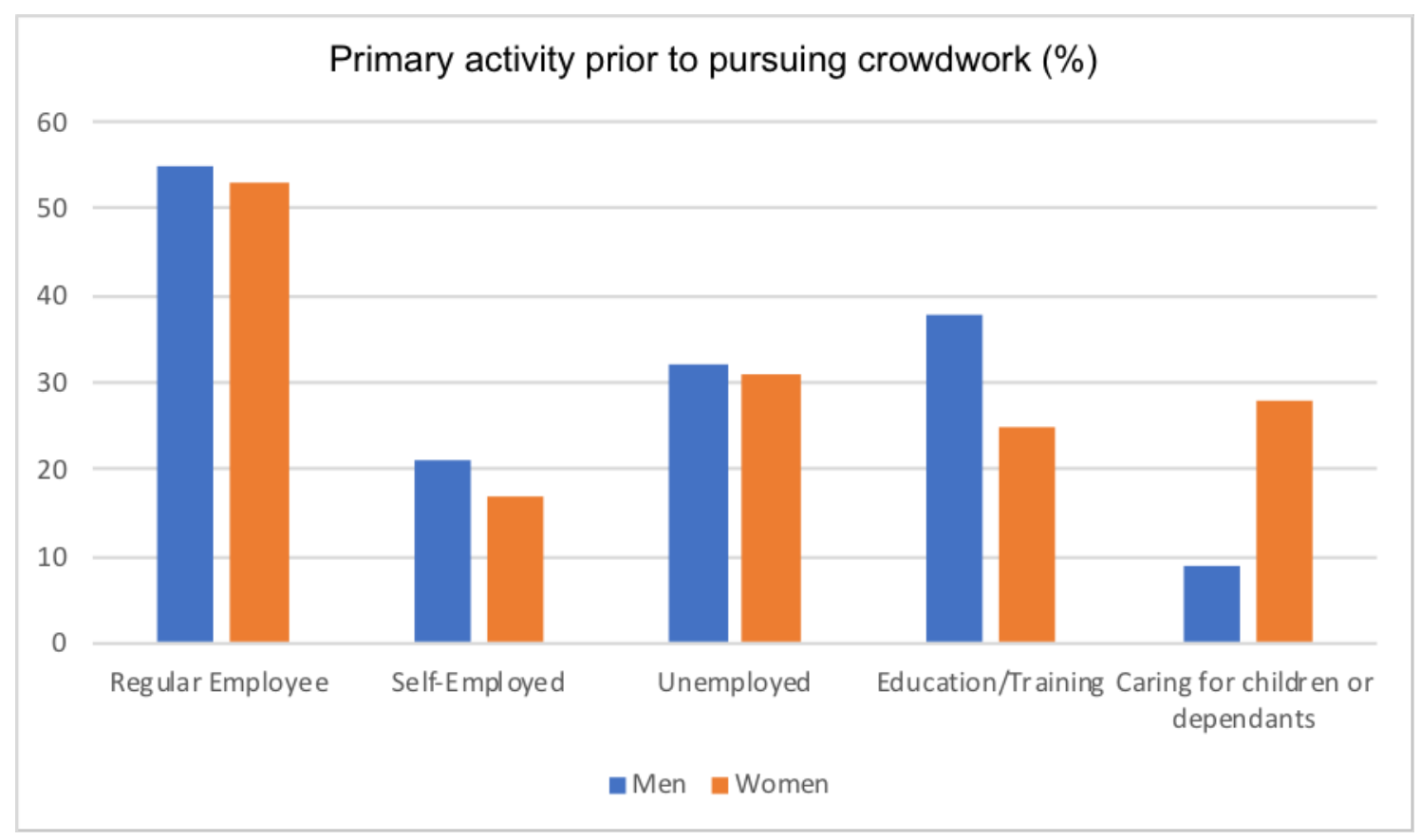

Figure 1: Activity prior to pursuing crowdwork (own image based on data source: Berg et al. 2018)

In mainstream narratives, crowdwork is generally posited as a source of secondary income. But this is true for only about a third of the workers, for whom the most important reason for performing crowdwork was to "complement pay from other jobs" (Berg et al. 2018, 37).Yet, as the ILO survey revealed "dependence on crowdwork was much higher than what was reported" (41). About 48 percent of the workers "were not engaged in any other type of employment" while an "additional 8 percent had another job but earned more from crowdwork than in the other job", implying that "for 56 percent of the respondents the main income source was crowdwork" (41). Overall, $80 \%$ of workers surveyed reported that their wages were a substantial portion of their household income and roughly two thirds said, "it was necessary for meeting their basic needs" (41).

Finally, as the CWC explains, a perpetual feature of the lives of workers under capitalist relations is the element of obtaining the work itself. In the Industrial era, Engels points to the "hundreds of poor men" who could "be seen before daybreak in the hope of obtaining a day's work" (Engels 1845, 385). Similarly, roughly nine out of ten workers surveyed by the ILO in 2017 responded that "they would like to do more work" (Berg et al. 2018, 39). Moreover, this experience had marked regional variations; 98 percent of workers in Africa, 91 percent in Asia, and 90 percent in Europe and Central Asia expressed this sentiment compared to 80 percent in North America. Overall, four in ten crowdworkers were "actively looking for paid work other than crowdwork" (66). A worker on the platform, Clickworker, pointed out that "the most frustrating part of crowdwork is waiting for work" itself (62). As Engels would expect, fettered by capitalist relations this aspect of working conditions also remains unhinged by the promise of digitality.

\section{Conclusion}

A class which bears all the disadvantages of the social order without enjoying its advances, one to which the social system appears in purely hostile aspects 
- who can demand that such a class respect this social order? Verily, that is asking much! But the workers cannot escape the present arrangement of society so long as it exists, and when the individual worker resists it, the greatest injury falls upon himself (Engels 1845, 424).

The paper sought to reorient contemporary discussions of digital labour to Engels's persuasive critique of working conditions under capitalism. It argued that an appreciation of the CWC is vital to our understanding of the lived experiences of contemporary crowdsourced labour. However, in addition to its theoretical relevance, revisiting the CWC also has crucial implications for political praxis on the Internet. It is worth recalling that many socialist thinkers, who Engels would later call "utopian Socialists", had already written about the miserable conditions of the working classes. Engels's distinction was to present the working classes not merely as a "suffering mass" but as a "revolutionary force" (Engels 1845, 433). As Lenin would note, the CWC was the first text to explicitly state that the "the disgraceful economic condition" of the worker propels "it irresistibly forward and compels it to fight for its ultimate emancipation" (Lenin 1895, 22).

However, a number of aspects will have to be adequately addressed before a global struggle of digital laborers becomes the political force that Engels envisioned. Contemporary critics of digital capitalism will have to pay closer attention, as Engels indeed did, to the differences within the digital working-classes by focusing on the diversity of social relations and economic circumstances that propel digital labour. Given Engels's commitment to internationalism, theorists will have to zoom-into the demographic, gendered, class, and national specificities of digital labour processes. As digital surplus-value appropriation differentially impacts those that it exploits, a transnational exploitative regime calls for a multi-tiered collective praxis beyond national borders.

Moreover, revisiting the CWC to critically understand digital working conditions can also point towards a systematic rethinking of concrete forms of post-capitalist transformation in the digital era. In particular, platform cooperativism can "foster social change by creating a People's Internet and replacing corporate-owned platforms with user-owned co-operatives" (Sandoval 2020, 801). These alternatives, in turn, could provide a befitting challenge to the exploitative regimes of the corporate sharing economy (Scholz 2016).

A return to Engels's CWC will also be crucial in responding to critics who argue that Marxian critiques are tied to the industrial world. Revisiting the CWC will allow us to thoroughly debunk this myth and appreciate that while the appearance of labour processes has drastically transformed during the past two centuries, its content in terms of capital-labour relations, the exploitative micromanagement of worker's lives, the gendered and racial dimensions of this exploitation, the helplessness that propels the worker, and the surplus-value enrichment of digital companies at the expense of workers remains inherently unchanged at its core. As in industrial England, long underpaid hours leave digital workers seeking refuge in drugs. Much like their industrial predecessors, the working conditions faced by digital proletarians are monotonous, misogynistic, and mentally debilitating and a return to Engels's work remains crucial in carving a global collective response against it.

\section{References}

Amazon Mechanical Turk. 2017. Participation Agreement. Accessed October 1, 2020. https://www.mturk.com/participation-agreement 
Azhar, Shahram. 2020. Consumption, Capital, and Class in Digital Space: The Political Economy of the Pay-per-Click Business Models. Rethinking Marxism. Accessed October 3, 2020. DOI: https://doi.org/10.1080/08935696.2020.1750196

Beerepoot, Niels and Bart Lambregts. 2014. Competition in Online Job Marketplaces: Towards a Global Labour Market for Outsourcing Services? Global Networks: A Journal of Transnational Affairs 15 (2): 236-255.

Berg, Janine, Marianne Furrer, Ellie Harmon, Uma Rani and M. Six Silberman. 2018. Digital Labour Platforms and the Future of Work. International Labour Organization. Geneva: International Labour Office.

Bourke, Michael and Sarah Craun. 2014. Secondary Traumatic Stress Among Internet Crimes Against Children Task Force Personnel: Impact, Risk Factors, and Coping Strategies. Sexual Abuse 26 (6): 586-609.

Burston, Jonathan, Nick Dyer-Witheford and Alison Hearn, eds. 2010. Digital Labour: Workers, Authors, Citizens. Ephemera: Theory \& Politics in Organization 10 (3).

Cherry, Miriam. 2016. Beyond Misclassification: The Digital Transformation of Work. Comparative Labour Law and Policy Journal 37 (3): 544-577.

Chen, Adrian. 2017. The Human Toll of Protecting the Internet from the Worst of Humanity. The New Yorker, January 28, 6

Choudary, Sangeet Paul. 2018. The Architecture of Digital Labour Platforms: Policy Recommendations on Platform Design for Worker Well-being. Geneva: International Labour Office. Accessed October 1, 2020. https://www.ilo.org/wcmsp5/groups/public/---dgreports/--cabinet/documents/publication/wcms 630603.pdf

Engels, Friedrich. 1878. Anti-Dühring. Herr Eugen Dühring's Revolution in Science. In Marx \& Engels Collected Works (MECW) Volume 25, 5-309. London: Lawrence \& Wishart.

Engels, Friedrich. 1845. The Condition of the Working-Class in England. In Marx \& Engels Collected Works (MECW) Volume 4, 297-596. London: Lawrence \& Wishart.

Engels, Friedrich. 1844. Letter to Marx November 19, 1844. In Marx \& Engels Collected Works (MECW) Volume 38, 9-14. London: Lawrence \& Wishart

Fuchs, Christian. 2017a. Capitalism, Patriarchy, Slavery, and Racism in the Age of Digital Capitalism and Digital Labour. Critical Sociology 44 (4-5): 677-702.

Fuchs, Christian. 2017b. The Information Economy and the Labour Theory of Value. International Journal of Political Economy 46 (1): 65-89.

Fuchs, Christian. 2015. Culture and Economy in the Age of Social Media. New York: Routledge.

Fuchs, Christian. 2014. Digital Labour and Karl Marx. New York: Routledge.

Fuchs, Christian. 2013a. Class and Exploitation on the Internet. In Digital Labour: The Internet as Playground and Factory, edited by Trebor Scholz, 211-224. New York: Routledge.

Fuchs, Christian. 2013b. Theorizing and Analysing Digital Labour: From Global Value Chains to Modes of Production. The Political Economy of Communication 2 (1)Ö 3-27.

Fuchs, Christian. 2007. Transnational Space and the "Network Society". Twenty-First Century Society 2 (1): 49-78.

Fuchs, Christian and Nick Dyer-Witheford. 2013. Karl @ Internet Studies. New Media and Society 15 (5): 782-796.

Fuchs, Christian and Marisol Sandoval. 2014. Digital Workers of the World Unite! A Framework for Critically Theorising and Analysing Digital Labour. tripleC: Communication, Capitalism \& Critique 12 (2): 486-563. Accessed October 1, 2020. https://www.triplec.at/index.php/tripleC/article/view/549

Fuchs, Christian and Sebastian Sevignani. 2013. What Is Digital Labour? What Is Digital Work? What's their Difference? And Why Do These Questions Matter for Understanding Social Media? tripleC: Communication, Capitalism \& Critique 11(2): 237-293. Accessed October 1, 2020. https://www.triple-c.at/index.php/tripleC/article/view/461 
Gillett, Rachel. 2017. Why Facebook is the Best Place to Work in America. Business Insider, December 7. Accessed October 1, 2020. www.businessinsider.com/facebook-best-placeto-work-in-america-2017-12

Hara, Kotaro, Abigail Adams and Kristy Milland. 2018. A Data-Driven Analysis of Workers' Earning on Amazon Mechanical Turk. In Proceedings of the 2018 Conference on Human Factors in Computing Systems, edited by Regan Mandryk and Mark Hancock, 1-14. New York: Association for Computing Machinery.

Hill, Steven. 2017. Raw Deal: How the "Uber Economy" and Runaway Capitalism Are Screwing American Workers. London: Macmillan.

Irani, Lilly. 2015. Difference and Dependence Among Digital Workers: The Case of Amazon Mechanical Turk. South Atlantic Quarterly 114 (1): 225-234.

Irani, Lilly. 2013. Turkopticon: Interrupting Worker Invisibility in Amazon Mechanical Turk. In Proceedings of CHI '2013 SIGCHI Conference on Human Factors in Computing Systems, edited by Wendy Mackray and Stephen Brewster, 611-620. New York: Association for Computing Machinery.

Lenin, Vladimir llyich. 1895. Frederick Engels. In Collected Works of Lenin Volume 2, 15-28. Moscow: Progress Publishers.

Magubane, Bernard. 1985. Engels: The Condition of the Working Class in England Revisited; Relevance for Urban Anthropology. Dialectical Anthropology 10 (1): 45-68.

Mahmud, Tayyab. 2012. Debt and Discipline. American Quarterly 64 (3): 469-494.

Marx, Karl. 1867. Capital Volume I. London: Penguin.

Martin, David, Benjamin Hanrahan and Neha Gupta. 2014. Being a Turker. In Proceedings of the $17^{\text {th }}$ ACM Conference on Computer Supported Cooperative Work and Social Computing, 224-235. Baltimore: Association for Computing Machinery.

McInnis, Brian, Dan Cosley, Nam Chaebong, and Gilly Leshed. 2016. Taking a HIT: Designing Around Rejection, Mistrust, Risk, and Worker's Experience in Amazon Mechanical Turk. In Proceedings of the $2016 \mathrm{CHI}$ Conference on Human Factors in Computing Systems, edited by Jofish Kaye and Allison Druing, 2271-2282. New York: Association for Computing Machinery.

Newton, Casey. 2019. The Trauma Floor: The Secret Lives of Facebook Moderators in America. The Verge, February 25. Accessed August 10, 2020. www.theverge.com/2019/25/18229714/cognizant-facebook-content-moderator-interviewstrauma-working-conditions-arizona

Nickerson, Jeffrey. 2014. Crowd Work and Collective Learning. In Technology-Enhanced Professional Learning: Processes, Practices, and Tools, edited by Allison Littlejohn and Anoush Margaryan, 39-49 New York: Routledge.

Peck, Jamie and Adam Tickell. 2002. Neoliberalizing Space. Antipode 34 (3): 380-404.

Peck, Jamie and Nik Theodore. 2012. Politicizing Contingent Work: Countering Neoliberal Labour Market Regulation from the Bottom Up? South Atlantic Quarterly 111 (4): 741-761.

Prolific. 2020. Prolific Terms of Service. Accessed October 1, 2020. https://www.prolific.co/assets/docs/Researcher Terms.pdf

Roberts, Sarah. 2019. Behind the Screen: Content Moderation in the Shadows of Social Media. New Haven, CT: Yale University Press.

Roberts, Sarah. 2016. Commercial Content Moderation: Digital Labourer's Dirty Work. In The Intersectional Internet: Race, Sex, Class, and Culture Online, edited by Safiya Umoja Noble and Brendesha Tynes, 146-158. New York: Peter Lang Publishing.

Sandoval, Marisol. 2020. Entrepreneurial Activism? Platform Co-Operativism Between Subversion and Co-Optation. Critical Sociology 46 (6): 801-817.

Scholz, Trebor. 2016. Platform Cooperativism: Challenging the Corporate Sharing Economy. New York: Rosa Luxemburg Stiftung New York Office.

Scholz, Trebor, ed. 2012. Digital Labour. The Internet as Playground and Factory. New York: Routledge. 
Schriner, Andrew, and Daniel Oerther. 2014. No Really, (Crowd) Work is the Silver Bullet. Procedia Engineering 78: 224-228.

Van Doorn, Niels. 2017. Platform Labour: On the Gendered and Racialized Exploitation of Low-Income Service Work in the 'On-Demand' Economy. Information, Communication \& Society 20 (6): 898-914.

\section{About the Author}

Shahram Azhar

Shahram Azhar is an Assistant Professor of Economics at Bucknell University. Research interests include political economy of digital capitalism and development economics. 


\title{
The Political Economy of Working-Class Social Media Com- merce: Digital Capitalism and the Engelsian Concept of Work- ing-Class "Property"
}

\author{
Suddhabrata Deb Roy \\ University of Otago, Aotearoa New Zealand, debsu680@student.otago.ac.nz
}

\begin{abstract}
Social Media platforms, from being simply a mode of communication, have, recently, evolved into digital "marketplaces", which have been facilitating the exchange of commodities within the working-class. In addition to the digitalisation of the medium of exchange value creation, which gives the worker a certain amount of regulated autonomy, this has also reinvigorated the debate about owning property and its utilisation for credit and profit generation by the working-class. The term, 'Property' in the paper, is not restricted to only real estate property but encompasses everything which has the potential to generate an exchange value for its owner. The paper generalises Engels's ideas about property owned by the workers from two of his major works, "The Housing Question" and "The Condition of the Working-Class in England" and uses the same to analyse the political economy and growing popularity of social media- based commerce among the working-class. Through data collected from the university town of Dunedin in Aotearoa New Zealand, a town with an extensive and established system of social media-based commerce, the paper puts forward the relevance of the Engelsian critique of the idea of uplifting the working-class simply by giving them control over the possession of property, in the age of digital capitalism. In doing so, the present paper talks about how digital capitalism utilises social media and its associated platforms for commercial exchange to keep the cycle of accumulation in the capitalist social system intact by further exploiting the working-class.
\end{abstract}

Keywords: Friedrich Engels, digital capitalism, housing question, property, social media, working-class

Acknowledgement: The author would like to thank the editor for his comments and suggestions. The author also thanks Associate Professor Marcelle C. Dawson and Associate Professor Annabel C. Cooper of the University of Otago for their insightful comments, along with Ms. Laura Starling for her help in conducting the study. Finally, the author thanks the interviewees who participated in this project.

\section{Introduction}

Friedrich Engels has been one of the most controversial yet influential figures of Marxist theory since the death of Marx in 1883 (Mavroudeas 2020). Two of his most famous works, namely, "The Condition of the Working-Class in England" (1845) and "The Housing Question" (1872) have long been seen as classics within urban sociology and anthropology. However, in both these works, Engels brings forward certain very important points related to political economy and the ownership of property by the working-class, which almost always get overshadowed by his brilliant depictions and analysis of the terrible conditions of the working-class lives. Engels speaking from a perspective informed by industrial capitalism, approaches the term "property" through a paradigmatic lens of housing and land. Property, however, is a contested term within the contemporary information and post-industrial society because of the complexities 
which have arisen within the information society, especially in terms of non-physical but material entities like information and knowledge themselves becoming properties with significant exchange and rentier values (Fuchs 2019a). However, the significance of the term "property", be it psychological or physiological, is immense within Marxist theory as, "[c]ommunists [...] bring to the front, as the leading question [...] the property question, no matter what its degree of development at the time" (Marx and Engels 1848, 519).

To Engels (1892), private property is primarily a tool of social domination which serves to keep the social status quo intact. His ideas surrounding the properties owned by the working-class clearly lay out the methods through which the capitalist social system uses the working-class owned properties for its own benefits (Engels 1872). Engels (1892) mentions that capitalism utilises the fact that the working-class owns properties and is thus hypothetically placed in a position to extract monetary value out of the same, to reduce the general wage levels in the society. It does so, so as to provide the exploiter and purchaser of the labour-power of the working-class, capitalism, the complete surplus value (Engels 1892). Engels (1878) also realised that this surplus value cannot be appropriated unless there is a distributive mechanism which actively aids this purpose. This realisation made him progress from his ideas of property and talk about the method of distribution within capitalism and its impact on the creation of class differences (Engels 1892). He brings forward how new means and modes of production are initially resisted by the old mode of distribution (Engels 1892). Within contemporary capitalism, both these ideas find relevance because not only is there a valorisation of working-class property directly in terms of exchange value and accumulation of profits, but it is the mode of distribution and circulation itself, highly communicative in nature, which becomes an active facilitator of the new source of profit-accumulation.

Communication has always been the foundation upon which the socio-economic fabric of the society is constructed, and social media is an important component of the same within the information society of the twenty-first century where it is not only a technology but rather a techno-social system (Fuchs 2014c). Burston, Dyer-Witheford and Hearn (2010) also associated this digitalisation of the society with the actually existing socio-political realities, and opined, "the term 'digital' does not simply refer to digital machines and processes but to the entire political, social and economic context and infrastructure within which they have emerged. This is how we now live in the "digital age" (Burston, Dyer-Witheford and Hearn 2010, 215). While the previous centuries were dominated by industrial and finance capitalism, contemporary society has witnessed a gradual evolution towards the primacy of information (Castells 2009), where information has become a major aspect of the capitalist production and circulation process. This alteration of the capitalist production and circulation process was done through an emphasis on the utilisation of information and communication technologies (ICTs) such as computers and televisions, which function digitally and not mechanically. Castells (1996/2010) rightly extends this by saying that though "information" has been central to human societies since a long time, the peculiarity of the contemporary usage of ICTs is that communication and information have evolved into being a raw material for the production of surplus value.

The present paper focuses on one of the most recent, yet most dynamic, innovation in the domain of digital communication - social media, more precisely Facebook. Within the large domain of functions, which Facebook performs along with its primary functionality of aiding communication between the users, the emphasis of the paper is on the element of working-class commercial activities within Facebook. 
Technology does not operate within a vacuum. Since Facebook draws a huge share of its revenue from advertisements (Fuchs 2008; 2014c), it has an implicit interest in keeping its advertisers afloat and thus also has a stake in avoiding the economic crash be it through an accumulation crisis (O'Connor 1984) or through an overproduction crisis (Mandel 1978) or through any other forms of crisis. This again calls for an understanding of communication that can analyse social media use as a material practice itself (Fuchs 2020; Mosco 2009) and social media's utilisation as a facilitator of capital accumulation. The integration of the digital ecosystem with the physical "brick and mortar" framework of profit-accumulation is essential because, as Fuchs (2019a) rightly mentions, digital capitalism today, co-exists with "finance capitalism, hyper-industrial capitalism, crisis capitalism, authoritarian capitalism, neoliberal capitalism, mobility capitalism, global capitalism, etc." (Fuchs 2019a, 3).

Communication is fundamentally important to human society because it is the process through which individuals construct their sociality and become parts of social groups, relations and other collective social institutions (Fuchs 2020), either voluntarily or involuntarily. Capitalism uses this sociality of the human beings as a weapon for domination. Rosa Luxemburg (1913/2003) in her seminal work The Accumulation of Capital stated, "[t]he process of production is based on the continuation of two different, though closely connected factors, the technical and social conditions - on the precise relationship between men and nature and that between men and men" (Luxemburg 1913/2003, 4).

The relation between "men and men", referring to the importance of communication in the society, is in no way inferior as an analytical tool in theorising the contemporary modes of capitalist exploitation. The overcoming of the marginalisation of communication within Marxist theory (Fuchs and Mosco 2016) is critical if one is to analyse contemporary social relationships, which are products of the enclosures enforced upon society by digital capitalism (Hall and Stahl 2012). Such an analytical perspective is especially important when certain forms of technology have become so normalised that they have become an integral part of human sustenance itself. It should be noted here that most of the technological innovations that have been normalised in the daily lives of people are communicative in nature.

The idea that communication has always been an important factor in the generation and sustenance of class inequalities (Fuchs and Mosco 2016), is further accentuated when these normalised communicative technological advancements are used for the accumulation of profits, as is the case of the subject that is the focus of the present paper - social media commerce in the context of working-class property. The digital means of value creation use the relationship between labour and digital technologies along with the existing modes of social organisation within capitalism to continue alienating the workers from the means and products of their own production (Fuchs and Sevignani 2013, 204). Keeping up with this evolution, social science has also brought in new techniques and conceptual paradigms to analyse the new form of society such as "free labour" (Terranova 2000) , "immaterial labour" (Hardt and Negri 2000), "digital labour" (Fuchs and Sevignani 2013), and the like. One of the primary aspects of almost all these various understandings of labour within contemporary society is the emphasis on how labour as a conceptual element intersects with the political economy of ICTs (Briziarelli 2014) in digital capitalism.

The present paper attempts to argue that digital capitalism has brought forward a method of profit-accumulation and reproduction of capital by converting the personal property of the working-classes, be it in the form of housing or other artefacts, into commodities with exchange value and coercing the working-class into, as Engels 
(1843) says, utilise them for the fulfilment of reciprocal needs and requirements, especially through trade and commercial activities. It has done so by bringing forward digital modes that encourage such commercial practices and subsume the working-class in within these modes of circulation.

The central questions that the current paper attempts to answer are the following ones: What is the relevance of working-class social media commerce in sustaining the capitalist system? How does this form of digital commerce utilise existing networks of digital communication?

First, the paper engages with the processes through which social media commerce is aiding the transformation of the personal properties of workers into commodities of commercial trade. Second, taking cue from that, the paper analyses the conditions and causes under which workers engages in social media commerce with other members of society who, more often than not, are also from the working-class. Finally, based on the two problematised analytical situations mentioned above, the paper goes into bringing forward an attempt to understand how social media commerce is changing the fabric of social reality. It argues that the rapid growth of social media commerce is emerging as a tool, aided by the crisis of neoliberal capitalism, that is converting society into a society of customers. All the three aspects mentioned above contribute to an understanding of how social media commerce supports capitalist profit accumulation, both digitally and physically, either directly or indirectly by exploiting the perennial social crisis and rampant consumerism already existing within society.

\section{Working-Class Social Media Commerce: A New Paradigm Within the Capitalist System}

Social media, one of the most recent advancement in technology, bases itself on communication and uses communication to extract further profits and surplus value from the working-class. Primarily, it does so through targeted advertisements and encouraging the users to spend time on the platform (Fuchs 2019; 2015; 2014c). This encouragement occurs through masking its capital accumulation model (Fuchs 2017) by making platforms free to use. It also attains a high level of participation because it provides the users a brief respite from capitalism's mass scale alienation (Fuchs 2017). Social media commerce, especially within the working-classes, capitalises on this very element of respite by using digital communities and spaces created by the users for promoting commercial activities between them and thus again pushing the working-class into an alienated existence dominated by capital.

Social media commerce, in the context of the current paper, refers to commercial activities on social media platforms such as Facebook and to certain extent, Instagram. The focus of the paper is on Facebook because the commercial aspect of social media on Instagram is still not as developed as it is on Facebook ${ }^{1}$. It must be mentioned at the onset that social media commerce, in the current context, does not refer to ways in which Facebook earns its revenue directly, but rather encapsulates the processes where users engage in commercial activities on social media that aid larger capitalist firms to make profits both within and outside the digital ecosystem. It is the analysis of this relationship that this paper attempts to bring forward.

\footnotetext{
${ }^{1}$ However, Facebook has been attempting relentlessly to initiate the process on Instagram as well through Instagram Shops https://about.fb.com/news/2020/05/introducing-facebookshops/
} 
Social media commerce helps capitalism in the development and scattering of networks, which as Banaji (2020) describes, is one of most important properties of capitalist accumulation strategies. Marxist terminology terms this very quality, as Banaji (2020) mentions, the moment of circulation within the capitalist cycle of accumulation. The development of these networks also emphasises the shift from industrial capitalism to newer forms of capitalism. In the contemporary society dominated by digital capitalism, social media takes up the task of generating these networks of circulation, which were previously dominated by merchants and traders (Banaji 2020). This functionality also makes social media a typical case of the techno-social model (Fuchs 2021 , chapter 2) that emphasises the social character of technological innovations under capitalism. Facebook brought forward FM (Facebook Marketplace) in the year 2016 as an extension of its already well-established technological framework. The official declaration from Facebook regarding the ushering in of Marketplace on the social media platform stated,

Facebook is where people connect, and in recent years more people have been using Facebook to connect in another way: buying and selling with each other. This activity started in Facebook Groups and has grown substantially. More than 450 million people visit buy and sell groups each month - from families in a local neighborhood to collectors around the world. To help people make more of these connections, today we're introducing Marketplace, a convenient destination to discover, buy and sell items with people in your community. Marketplace makes it easy to find new things you'll love, and find a new home for the things you're ready to part with. We'll continue to build new options and features to make this the best experience for people ${ }^{2}$.

As is evident from the statement itself, Marketplace or FM, was designed so as to exploit the relations of communication that users had built up on the social media platform. "Marketplace makes it easy to find new and used items such as clothes, furniture, cars and even your next home to rent" 3 . FM encourages the usage of social media as a means of intra-working class or intra-user commerce. FM, in some ways, capitalised upon the practices of "Buy and Sell" groups on Facebook. These "Buy and Sell" groups, however, operated more as normal groups, where the user had to describe manually the details of the product listed. FM did away with all of these lengthy procedures and made it easy to list commodities for sale with a full-fledged user interface integrated within Facebook to aid in listing the commodities and accurately describing the state of usage they are in, which points towards, in Marxian terms, the unused use-value of the commodity on sale.

${ }^{2}$ See https://about.fb.com/news/2016/10/introducing-marketplace-buy-and-sell-with-your-local-community/

${ }^{3}$ See https://www.facebook.com/marketplace/learn-more/buying 


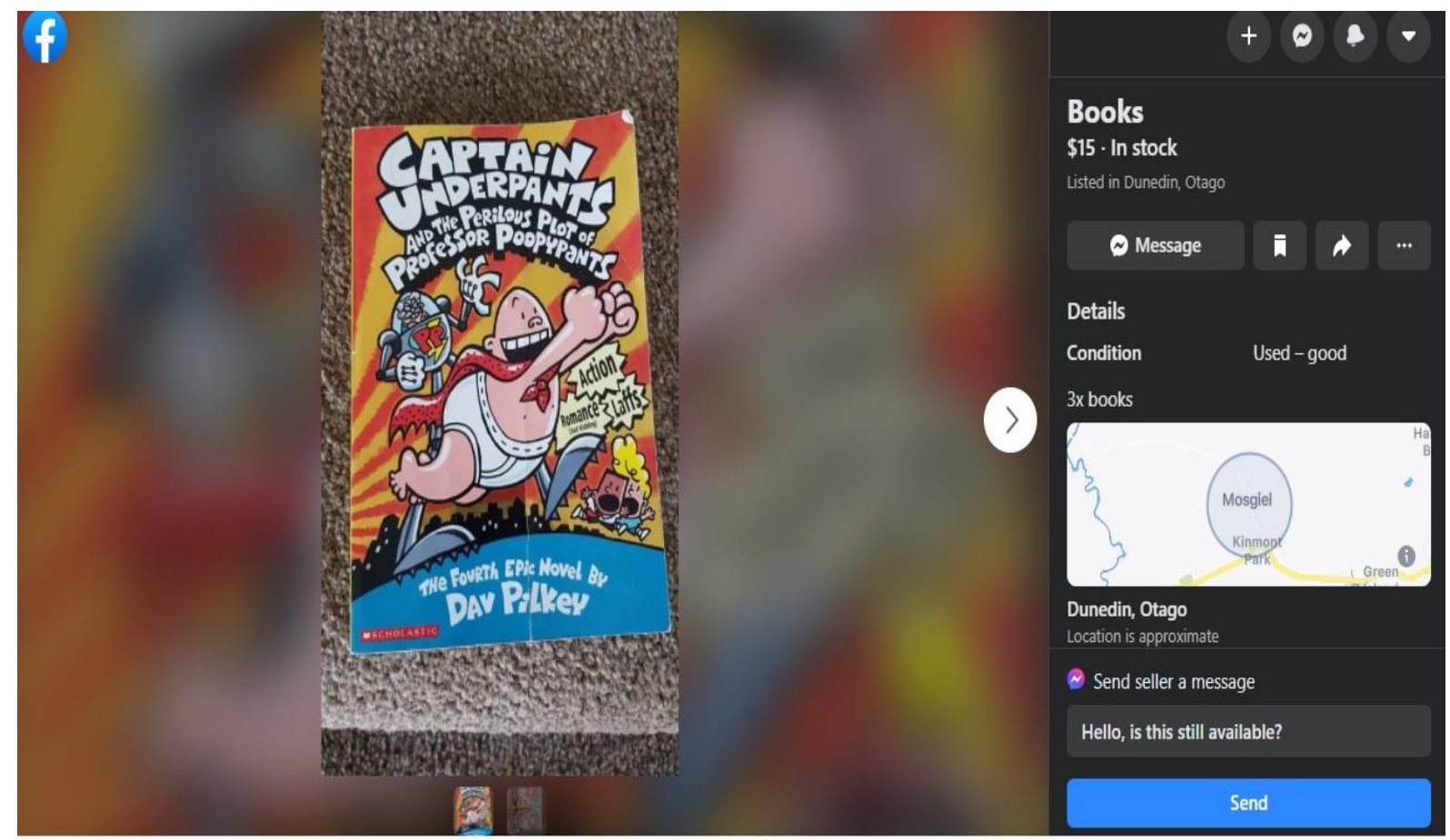

Figure 1: A book on sale on Facebook. Facebook makes it easier to describe the condition and location of the commodity. (Source: Facebook Marketplace)

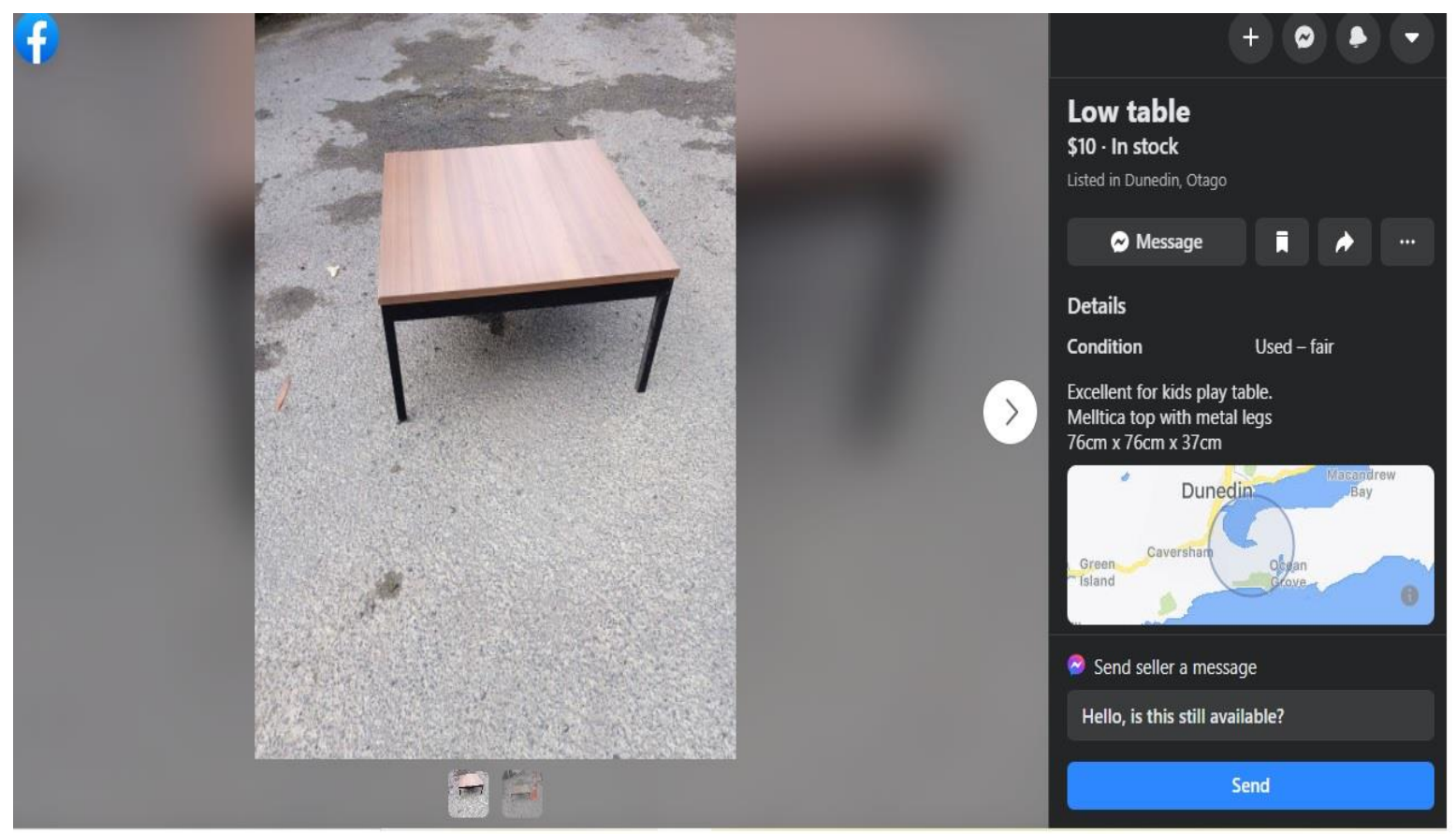

Figure 2: A table listed on Facebook with an elaborate description. It can be noticed how Facebook provides an instant option to get in contact with the seller with preconfigured messages. (Source: Facebook Marketplace)

The introduction of FM, or rather the institutionalisation of social media e-commerce, has furthered the practice of "buy and sell" and has made buying and selling more mobile, institutionalised and popular. The increase in mobility was achieved through the integration of a designated FM tab in the Facebook app that allows the user to access the Marketplace option more easily in comparison with commercial FB groups, 
for which a considerable amount of Internet data had to be used in addition to the complexities raised by the user interface itself.

The current study is based in Dunedin, a city located in the south of Aotearoa New Zealand with a population of approximately $125,000^{4}$. It has five well established networks of social media commerce on Facebook Marketplace, namely, "Otago Flatting Goods", "Otago Flatting Goods II", "Second Hand Books Otago Uni", "Dunedin Buy/Sell/Trade", and "Otago Flatting Goods for Students" 5 . The 5 groups combined on average had around 29 listings every day over the last six months. The users in these groups mostly focus on the buying and selling of used products ${ }^{6}$. Some of the most commonly listed or sold items on the groups are clothes, books, household amenities, etc. In addition, there are also occasional listings of flats and other accommodation related products. There are almost no centralised listings i.e., the number of listings coming from companies or agencies focused on pure commercial trading. Occasionally new products are listed ${ }^{7}$ but mostly sales are focused on used goods.

Through volunteer sampling, a total of ten respondents were selected for participation in this pilot study. Following selection, in-depth interviews were conducted with each of the respondents where a variety of questions were asked including the reason of their usage of social media for commercial activities like buying and selling instead of established websites like eBay or TradeMe, their usage of the money they received through selling of their personal products, etc. These respondents were selected based on the number of items which they have listed on Facebook for sale over the last 6 months. Out of the total interviewees, three (3) were engaged in doing manual labour where the rest were engaged in either academic or other forms of intellectual or digital labour.

\section{Social Media Commerce as a Site of Exploitation}

Jenkins (2008) describes social media to be an expression of the culture of participation, where "consumers are invited to actively participate in the creation and circulation of new content" (Jenkins 2008, 331). His ideas focus on social media's capacity to be the foundation of an alternate media which can destroy the monopolistic control over media following which, media can become democratised. However, as Fuchs (2014b; 2014c) shows, social media is not a completely democratised space but rather is an extension of the authoritarian social system. This relation between technology and society has tremendous influence over the everyday lives of people as technological advancements, in every era, have come to define what Gardiner (2000) calls the style of life. For instance, Qui, Gregg and Crawford (2014) described the iPhone to be a watershed moment in the history of techno-cultural advancement because it represented a paradigmatic shift in the manner in which social practices within and outside the industries was organised and conceptualised. Crawford previously had described the iPhone to be "a key moment of metastasis when an already intimate, popularized technology expanded to encompass a host of media forms" (Crawford 2012, 219).

Social media commerce, similar to the iPhone, is also one such moment because it has fundamentally transformed the ways in which the non-capitalist classes engage in the circulation and distribution process. It has significantly altered the dynamics of

\footnotetext{
${ }^{4}$ Refer to https://www.stats.govt.nz/tools/2018-census-place-summaries/dunedin-city

5 These are public groups that can be easily found on Facebook.

${ }^{6}$ There are other commercial FB groups that focus on small and independent producers' direct sales.

${ }^{7}$ Products that have been bought but not used at all.
} 
ownership by ensuring a constant circulation of both commodities and money within the capitalist society which allows it to further accumulate profits. In the entire process, it must be remembered that both the "producer" and the "consumer" of the commodity, understood in the classical Marxist sense as anything which satisfies the needs of the individual (Marx 1867), within social media commerce almost always come from the same social class. This exchange within the working-class of the personal properties of the working-class, which is itself entrenched within a crisis ridden system, ensure that the class mobility of the working-class remains stagnant. Taking cue from Engels (1845) on this process, one can also say that the entire cycle of social media commerce ensures that nobody has the potential of "rising above their class" (Engels 1845, 321) because the exchange value "temporarily accumulated" by the working-class again gets formally accumulated either as direct profit or rent by the capitalist class.

Social media commerce within this socio-political milieu, can be said to be one of the most important aspects of social media today where there is a direct overlap between the existing economic system and the manner in which people use social media. The expansion of the term "digital" can also be used to put into perspective in relation to the capitalist strategy to allow people to sell physical "items" to other people directly, in the process turning them into commodities, without any intermediary except the digitalised medium facilitating the exchange. This exchange can be looked at either through a simplistically optimistic or through a critically informed paradigm. There are significant voices which have argued, from the former perspective, that with a massscale social level digitalisation of everything, capitalism will eventually come to an end because it will lose its ability to draw surplus value from most of the commodities (Mason 2016). However, this view does not take into account the power of capitalism to restructure itself with the changing dynamics of society.

Engaging in commercial activities through social media is significantly different than other digital e-commerce platforms like Amazon or eBay because social media commerce is a site of the direct exploitation of communicative and social media labour where the combined labour of users is exploited in creating the symbolism associated with the technology (Fuchs 2015; Hardt and Negri 2000). While for Amazon or eBay operated marketplaces, the communication follows the actual exchange, for FM, it is communication itself which facilitates the exchange. Communication here, as Fuchs (2015) has highlighted, becomes a material force of exploitation within society. The desire to use communication as a material tool of accumulation has contributed to FM emerging as a popular tool for digital commerce among common people. Most of the people interviewed for the study responded in affirmative to the growing popularity of FM as a viable alternative to other e-commerce websites especially those selling used goods:

- "It depends on the item, but I generally look for second hand first, via Facebook".

- "If I get a good deal, I would be happy to buy from the marketplace. It is faster than others".

- "Always Facebook for used".

Another major difference is that while in the case of e-commerce sites like Amazon, it is the economic structure in its entirety which more often than not determines the price of the product or the commodity on sale, but in the case of FM, price is determined by a coalition of various factors such as the state of social crisis and the personal need of the seller. Needs, as Marx (1857/1858) pointed out, can be both natural and socially produced. Capitalism depends on the latter more than the former to produce surplus 
value. It is within the paradigm of the latter where it can produce consumerism which hinges upon an everlasting state of continuously evolving needs, which is a significant driving force behind the proliferation of commercial activities through social media in the hope of generating some individual monetary capital, even if temporarily. These needs are crucial for capitalism because as O'Connor (1984) argues, the needs of the working-class determine the demand for consumer goods, and if the demand for consumer goods increases, also the value composition of capital itself increases (O'Connor 1984,157$)$. Social media commerce caters to the process of satisfying this growing demand for consumer goods by temporarily allowing the working-class to control some amount of the exchange value of the commodity. The challenge for social science today is thus to come out with a holistic understanding of the term accumulation itself and the process in which it is being performed in the information society. It is something, which cannot be done unless one takes into account communication within the larger gambit of social processes, especially communication through digital means and the relationship which this form of communication shares with its non-digital predecessors.

Contemporary capitalism is "profoundly ideological" (Fuchs 2019a, 4) because it works through creating a universal consumerism and an all-encompassing commodification, which in turn, keeps on replenishing the old needs while at the same time, creating new needs within the society, which can only be satisfied by monetary capital. This entire process of the creation of new needs within society leads to the analysis of the production of new modes of consumption (Harvey 2006, 8) and takes one back to Marx's statement about money being the alien essence that dominates and subsumes human existence (Marx 1844, 172). As Marx $(1857 / 1858,408)$ mentions, the production of new consumption can only be produced through three distinct methods, "firstly quantitative expansion of existing consumption; secondly: creation of new needs by propagating the existing ones in a wide circle; thirdly: production of new needs and discovery and creation of new use values" (Marx 1857/1858, 408, quoted in Harvey 2006, 8)

Social media commerce allows capitalism to give vent to the above-mentioned processes. It gives the working-class access to a certain amount of capital, the usage of which depends upon external factors beyond their own control. The constant creation of new needs, either out of crisis or out of the consumerist nature of capitalist society, enables social media commerce to be a vital aspect of capitalist accumulation because it temporarily counters low wages in the economy, which cannot be mediated through normal e-commerce websites like Amazon where the relations between the value and the price of a commodity are more rigidly established.

The uniqueness of Facebook Marketplace or in general any other potential social media commerce platform is that these platforms work as a model that is based on communication and accumulation through indirect sales. They are also different from other models such as the one used by Airbnb and Uber because Facebook use for commercial activities is gratis. But Facebook is potentially more exploitative than other platforms because even though it does not charge a fee, it encompasses within its platform a diverse range of accumulation strategies, especially advertising that feeds on the user's cognitive instincts and commerce, which involves direct physical exchange. While other e-commerce websites work on a model based on the primacy of accumulation through direct sale, Facebook works through encouraging users to GET involved in resales so as to increase the direct sales of others, which are the platform's potential advertisement and financial sources. 
Fuchs $(2017,293)$ argues that Airbnb builds its capital accumulation model on individuals' alienation from the community in order to promise community experiences via Airbnb and commodify community. Community as ideology helps masking Airbnb and other capitalist platforms to their "for-profit capitalist businesses aiming at making monetary profits" (Fuchs 2017, 293), but also helps them in gaining a high level of social acceptability. Thus, although the exchange of commodities for money within the working-class is not entirely new with websites like TradeMe and eBay doing it for years, the new medium through which this exchange is being propagated within the society certainly demands academic attention because of its uniqueness in comparison to other established modes of this form of exchange. Coupled with cybernetic domination (Wiener 1961), it creates a scenario where every click and every message become a part and parcel of the profit-making mechanism of capitalism. Under this current mode, it does not matter if one is merely browsing or scrolling through social media. The entire digital ecosystem works in a manner that encourages and enables every activity into becoming a potential source of capital accumulation. A political economic analysis of social media commerce that proliferates through Facebook and the groups therein reveals the integration of social media commerce into the broader contours of the general structure of the capitalist economy that revolves around profit generation.

Facebook groups created for the purpose of commercial activities do not earn any revenue for the users or its facilitators. In an indirect fashion, they help keeping Facebook a gratis platform by diverting profits to its financiers by exploiting the constantly changing working-class composition that results in a constantly varying pool of needs and requirements within society (Hardt and Negri 2004) as well as the existing culture of consumerism at a mass scale (Fuchs 2019a). This culture of consumerism works through the conversion of human beings into nothing but profit-making machines (Engels 1845). The conversion of individuals into appendages of the broader system of profit-accumulation is one of the most important effects of the rampant consumerisation of the society where each individual witnesses another individual as consumer and not a fellow human being. In other words, individuals become, as Engels (1845) says, a source of capital for further accumulation.

\section{The Information Society and Social Media Commerce}

Bell (1974) characterised contemporary society by two interrelated processes, the change from a goods based economic structure to a service and information based one, along with the increasing importance within the social structure being placed upon workers in the professional and technical sectors. While theorising social media commerce, this argument has to be extended and modified, because through the proliferation of platforms like FM, what one witnesses is a physical mode of commodity circulation within the working-class being promoted by a digital platform. The primacy of the information-based economy still holds but it is characterised, in certain cases like the present one, by a complicated web of social capital circulation based upon the exchange of physical commodities. Without the physical circulation of capital through exchange of commodities, the digital platforms cannot sustain themselves as the latter can only remain free and counter its own lower marginal costs by an economics of scale if the former keeps on accumulating profits and diverting those in the form of investments to the latter. So, while the "new men" like the mathematician and the scientist (Neilson 2018, 885) still hold a dominant position in the society, they cannot, on their own, be the controllers of the society since the reproductive value of the commodity produced by them is extremely low (Marx 1867). There, thus, arises the requirement of a physical circulation model, which can concurrently exploit, the materialistic needs 
of the people as well the digital labour of the people entwined within the alienated production process in the society.

Social media commerce facilitates the process of creation of capital of a new kind in the information society, where the relation between the price of the commodity and its value is different than what it had been under pure industrial capitalism. The value of a commodity, according to Marx (1867) is determined by an addition of three factors - constant capital, variable capital and surplus value while the price is fixed, as Rigi (2014) summarises, through a process which takes note of the supply and demand existing in the market. The price often exceeds the value, thereby paving the way forward for the creation of profits. The realisation of this surplus value and profit occurs in different forms such as interest, rent or through profits drawn from the market or by reducing the variable capital involved in the production process (Marx 1894). In the current age, along with these forms of accumulation, there is an additional accumulation of digital rent on information and advertising (Rigi 2014) as well, which has become a vital aspect of the sustenance of digital monopolies like Google and Facebook.

The free access to social media platforms like Facebook and Twitter as opposed to platforms like Airbnb where for the final product one has to pay a fee (Fuchs 2017) can be explained through two interrelated theoretical arguments. At first, one needs to acknowledge the relevance of Marx's (1867) insight that products of science, which are primarily products of mental labour, are almost always priced lower than its value because the labour-power required to reproduce the same is often significantly lower than the original labour-power invested. Taking cue from that, one can then refer to Staab and Nachtwey (2016) who take this further by saying that digital capitalism attempts to tackle this particular problem by reducing the market price of the products of science so that lower profits can be nullified by an economy of scale (Staab and Nachtwey 2016).

So, in spite of the fact that a huge amount of investment goes into, both in terms of constant and variable capital, creating an algorithmic platform like Facebook Marketplace, which can facilitate commercial activities on social media, charging a rent or a fee for access would simply encourage other platforms to invade the niche space that platforms like Facebook have carved out for themselves. This becomes especially relevant in the case of Third World economies like India where sites like Airbnb and Uber have been facing tough competition from local platforms like Oyo Rooms and OLA. The free access to Facebook has not generated such competition. Additionally, the press releases made by Facebook regarding its free access to users establishes a public consciousness that helps retaining its tremendous user base ${ }^{8}$.

Facebook's economy of scale makes it easy for the platform to popularise any new development that it introduces. Facebook's task, in popularising parts of its framework like Marketplace, becomes easier because it is already a part of the digital eco-system in the domain of communication and advertising, with the latter constituting the bulk of its revenue model (Fuchs 2015; 2014c). The only thing which Facebook had to do to make Marketplace a dominant mode of distribution and circulation was to encourage its 2.45 billion $^{9}$ users to start using it to sell their personal property. For achieving this aim, Facebook made FM more accessible and doing away with any trading fees, which

\footnotetext{
${ }^{8}$ Facebook has made many such statements over the years. In 2018, it said, https://www.dailymail.co.uk/sciencetech/article-5600803/Facebook-WONT-charge-users-subscription-feeopt-targeted-ads-completely.html. Again, in 2019, https://www.businessinsider.com/facebook-changes-free-and-always-will-be-slogan-on-homepage-2019-8?r=AU\&IR=T

9 See https://www.businessofapps.com/data/facebook-statistics/
} 
most other domains charge. These combined and interrelated processes contributed towards Facebook's monopolisation of social media commerce.

A significant aspect of these monopolies is the rise of mobile applications (apps), and the purposes for which these apps are used which is again dependent to a large extent on communication and participatory culture. Facebook utilised this participatory culture already existing within its communicative platform to promote and expand FM. Engaging in commercial activities through Facebook nullifies some important factors which previously acted as hindrances within sites like eBay or TradeMe such as, initial investment, time and ease of access. With eBay or TradeMe, one needs to go through a certain process while listing the commodity, which is both time consuming, at times expensive and a bit complicated. Facebook, on the other hand, allows one to sell, "on the go" for free and with no success fees ${ }^{10}$. In other words, while on eBay, the listing process is more mechanical in nature, the listing process on Facebook is in a way organic in nature, which enables the user to make use of their spontaneous will and freedom. This fact can be verified to a certain extent, from the field data itself as three of the interviewees put it:

- "Facebook as a medium, as opposed to something like TradeMe, has the advantage of not requiring an investment to sell an item. So, I can get more out of the sale, as opposed to when I have to sell on TradeMe".

- "It's an excellent platform, free and easy to use. I stopped using TradeMe completely because the fees got too high".

- "I reckon it's an easy platform to sell things and better than TradeMe because TradeMe has the extra cost that goes to them whenever you sell any item. Facebook encourages me to sell more".

Theories about social media have often talked about the element of communication and its usage for digital profit generation by using communication as a production process in itself (Fuchs 2020; Williams 1980). While for the workers, it is the exploitation of variable capital by the capitalist in the form of wages which increase the profits of the capitalist, for the capitalist however it is the entirety of the social capital which produces the surplus value and in turn helps in increasing the rate of profit (Rigi 2014). By using the power of communication, the entire structure attempts to remain at an equilibrium by providing the capitalist with enough social capital to invest in producer goods by increasing the circulation of consumer goods through social media. The consumer goods produced from the producer goods, would again be out in the market with exchange values and the cycle of profit-accumulation, thus, continues.

\section{The State of Permanent Social Crisis}

Crisis, of any form, has a huge impact on the social fabric of any society. With every crisis, there occurs certain alterations within the society which become characteristic of societies as history moves forward. The present crisis, which has slowly but definitely become a permanent feature of lives under contemporary capitalism has somehow forced the working-classes to transform its personal properties into commodities. Personal properties are different from private property as they do not naturally, without a market to appropriate it, have the ability to generate profits. Social media commerce provides this market to encompass of all use value within the accumulative capitalist

${ }^{10}$ The fee payable to the website if the product gets sold. 
circuit thus promoting contemporary capitalism from being an agency of formal subsumption to an agency of real subsumption (Negri 2003). This process where the productivity of labour somehow becomes redundant because the production process itself becomes a commodity through a complete reorganisation of work through the application of communication technology, constitutes what Negri (1989) based on Marx (1867) calls real subsumption, the unequivocal and complete realisation of the law of value (Negri 2003; 1989). When users use Facebook to "sell on the go", they are not only being exploited on the basis of unpaid digital labour (Fuchs 2014a) but also on the basis of the fact that their productive forces no longer determine the value of their labour-power (Negri 2003). The relationship between the value of the commodity and labour-power become further complicated when the same kind of product is continuously used for profit-accumulation.

The act of resale does not generate profit for the capitalist directly but rather, it creates the conditions that make capital accumulation possible. So, while for the seller, it is true, that there is no profit because the resale usually gathers a lower price than the original one, the point that has to be studied is the direction of investment or expenditure of the generated price in the case of a resale. Harvey (2006) correctly argues that under a system that depends on commodity production, it is the exchange that determines the relationship or separates the aspects of production and consumption. Drawing from Marx (1867) that, Harvey argues that the concept of use value is the determining factor in establishing the relationship between commodities and human needs. However, use value is almost always related to the qualitative aspect of economic relationships while exchange value is related to the quantitative dimension. Under real subsumption, it is this relationship between the use value and exchange value that gets blurred because all use values, already utilised or hitherto unutilised, become potential avenues for the generation of exchange values.

Social media commerce aids the working-class to make use of the unutilised use value of the commodity. Hence, even though the resale of the used goods on social media does not make any profits for the working-class, it does allow the working-class to invest that money back into the market. If the resale had not taken place, and social media would not have accelerated or facilitated the process, this investment would not have taken place. Additionally, the person buying the commodity also pays for a certain amount of use value that the commodity can still offer, as a part of the same has already been used, and inevitably finds himself/herself again in need of the very same commodity in the future.

Mandel $(1975,525-526)$ characterises the primary sustaining factor of the socioeconomic fabric of the capitalist mode of production as the generalisation of commodity production. Social media commerce aids to sustaining generalised commodity production by temporarily enabling the working-class to satisfy its needs for consumer goods by consuming the commodities that have already been produced so that new commodities of the same kind can be produced for more consumption at a rapid pace. This new paced cycle of production requires investment from the working-class at regular intervals. As many as eight interviewees affirmed that they do in fact, buy or have to buy, the same kind of consumer goods, with the money they earn by selling their personal property. This temporary monetary capital or financial stability generated by the sale, thus, again gets accumulated as new profit for the capitalist who produces consumer goods.

According to Kowalik (2014), the Austro-Marxist Otto Bauer argued that capitalists who engage with the production of consumer goods constantly accumulate a portion of profits attributed to the production of producer goods, which then allow "for a more 
rapid production growth of the means of production" (Kowalik 2014, 62) can be a useful analytical argument to make in this regard. However, the current's assumption that there existed no problems of surplus value realisation (Kowalik 2014), can be critiqued based on the fact that it is precisely the problem of realisation during economic crisis, which makes capitalism invent these new methods to realise the already existing surplus value available for consumption in the market. This realisation, however, does not and cannot happen through the conventional methods because under the aegis of contemporary capitalism, the working-class is always surviving under the conditions of economic and socio-psychological crises. The economic crisis inevitably results in lowering the capacities of the working-class to consume commodities, which can call forth an overproduction crisis. The result of an overproduction crisis, again, is the failure of the capitalist infrastructure to realise the existing surplus value in the market because with the dwindling wages, the system simply does not allow the working-class to consume the commodities already available in the market. We are here reminded of Luxemburg's (1913/2003) idea that the absence of any regulatory mechanism on private production is a fundamental problem of capitalism (Luxemburg 1913/2003, 6). It is the absence of this regulation that subsequently leads towards overproduction and economic crisis. In other words, as long as capitalism evades the problem of realisation, the chances for it to avoid the crisis increase.

In the contemporary times, capitalism has reacted to this crisis of realisation by creating a mechanism that ensures that capital does not remain fallow (Mandel 1978; Engels 1843) but keeps on getting invested and circulated. In this regard, for the capitalist, the personal property of the working-class is a hindrance because in an overproduction crisis, it is temporarily blocking the worker to consume more commodities that have already been produced. Social media commerce ensures the mobility of capital in society in a manner that allows capitalism to counter this very problem. It uses the state of crisis to create a situation where working-class property is sold on social media, which enables the working-class to make a temporary gain out of the commodity as response to the state of crisis or to fulfil their consumerist needs. During the course of the present study, not many respondents talked about being able to save their money or even wanting to do that. In other words, except the exception of one respondent, who talked about saving money to repay a loan, which is also a form of capital accumulation, all the others affirmed to investing the money back into the market directly or indirectly, sometimes through rent payments or by buying the same kind of consumer goods that they had sold.

The digitalisation of the mode of exchange has facilitated a wide variety of commodities, which previously had limited exchange values to become significant aspects of further accumulation of profit. Capital has become financial money capital, a form where it becomes absolute and does not distinguish between producer and consumer goods during accumulation (Luxemburg 1915). Overproduction and its associated economic crisis (Mandel 1978) have also contributed to this popularisation of social media commerce. The existence of a huge inflow of consumer goods within the market with the majority of the population unable to buy those creates exactly the kind of problem that Bauer had rejected as Kowalik (2014) elaborates. In spite of the fact that FM allows the users to fix prices of their own, these prices are mediated by a complex web of social crisis and the resulting natural or social needs. The prices of these existing range of commodities determine the value which the working-classes put on their personal properties for sale in social media.

The freedom and accessibility provided by Facebook in listing the commodities can be seen in light of the argument made by Fuchs $(2016,37-42)$ that within capitalist 
structures, there is always a provision of relative freedom, which the system provides to the working-class to express themselves but within certain limits. Social media commerce enables the sellers to generate exchange value out of items which were only of use value previously and it does so by hinging on the continuous state of crisis and ever-increasing need within capitalism, both of which are dialectically related to each other.

One of the interviewees responded to be living on the streets due to eviction and thus had to resort to selling off personal goods to survive. The respondent admitted having been forced to keep the price low so as to facilitate quick sale, thus bringing in a new dimension to the procedure in which capitalism utilises the element of "time" for domination (Shippen 2014). In the case of social media commerce, this domination is performed through a continuous easing of the process of subsumption of the workingclass within the capitalist circulation process by exploiting the state of crisis and immediate needs of the working-class. This is also reminiscent of Engels's (1872) arguments about the housing properties owned by the working-classes whose prices vary significantly due to other associated processes which are outside their own control:

The growth of the big modern cities gives the land in certain areas, particularly in those which are centrally situated, an artificial and often colossally increasing value; the buildings erected on these areas depress this value, instead of increasing it, because they no longer correspond to the changed circumstances. They are pulled down and replaced by others. This takes place above all with workers' houses which are situated centrally and whose rents, even with the greatest overcrowding, can never, or only very slowly, increase above a certain maximum. They are pulled down and in their stead shops, warehouses and public buildings are erected (Engels 1872, 319).

The autonomy of the working-class, in a manner that reminds us of Engels's (1872, 319) description of housing, is at the mercy of capitalism in spite of the ownership of property. The sustenance of social media commerce depends on the sustenance of the crisis within the society, both materialistically and psychologically. Taking note of some of the answers which were revealed during the field work by the interviewees, the relation between needs, crisis and the act of selling become explicitly established:

- "I lost my job, so selling the items was the only way to go ahead".

- "I had just been forced to move to a new property, along with moving costs, on the first day I had to pay for other associated services, I had no money for food, I am unable to work and so selling was the only option left".

- "I had bills due so, I needed to make money fast, so I sold a few items".

Engels $(1872 ; 1845)$ was able to bring forward the conditions within which the workingclass could be coerced by the system into doing away with their properties. His emphasis that mere owning of properties cannot alter the exploitative relationship between the capitalists and the wage earner (Engels 1872) can be witnessed even today. The basic philosophy of capitalism which is to extract surplus value from the workingclasses, as Engels (1878) said, stands correct within the entire process of social media commerce. Facebook, it is widely known, generates a high amount of profits through the targeted advertisements listed on its user interface (Fuchs 2014c). It works through encouraging the people into using Facebook for a variety of different purposes through which it can redirect those users to the advertisers, the main source of sustenance of 
Facebook itself. Through the proliferation of social media commerce, capitalism attempts to maintain the delicate balance between the need-satisfaction of the workingclasses and the profit-accumulation of the capitalists by rendering the oppression of the working-classes invisible within digital capitalism so as to delay the socio-economic crisis or any form of social revolutionary movement.

\section{A Society of "Customers"}

The French Marxist Henri Lefebvre (1991) talked about the utilisation of social space, an all-encompassing element of the human society created by human beings themselves, as a means of production within capitalism. Space is an important concept in the present discussion because this is where the exchange gets facilitated. Engels's (1845) emphasis on the living conditions of the working-class and the dialectical relationship between those living conditions, their own properties such as housing and land, and the effect of those property holdings on their wages play a crucial part in explaining and analysing the social space which capitalism creates and utilises, as Lefebvre (1991) says, as a means of production. The contemporary social space is being increasingly mediated by communicative technologies, where social relations themselves have become digitalised in nature. This digitalised social space constitutes the social relations without which it is impossible for anything to find its way to the market (Marx 1867).

Marx, however, designated the factory to be the place where the process of surplus value creation is located in. Marx argued that the contract which formally bounded the employment relationship between the capitalist and the worker actually constitutes the basis of the production of surplus value. Contemporary capitalism has transgressed the limits imposed upon it by Marx in terms of "place" and has, through the utilisation of social space and communication, informalised the nature of contracts. This informalisation, driven by capitalism's desire to convert everything into profit generating commodities, has enabled it to commercialise the social relations formed by human beings and makes them see other human beings within the society as the possessors of private property or customers, at times both.

This is also similar to Bauman's (1999) concept of modernity where he states that the foundational ideology of the contemporary society is to place each human being as a commodity and a consumer (Bauman 2005). This, on its own, shapes the dialectical relationship between use and exchange values constituted by the fact that a commodity always has a certain, as Marx says, non-use value for those who own the commodity and a use value for those who do not own it. And the sustenance of capitalism as an economic system, depends on the sustenance of the capitalist society, a major aspect of which is to generate this exchange between the possessors and the nonpossessors on financial terms.

Bauman (2010) argues that technological innovations that affect dominant social practices are not entirely new aspects of society but rather are manifestations of already existing needs and processes. Taking cue from Bauman (2010) and relating it to O'Connor's (1984) analysis of individualism being the most powerful weapon in dominating the working-class, one can argue that social relations, even under digital capitalism, that are not only structured by communities but also by organisational forms that are technologically mediated and created (Hall and Stahl 2012), are working examples of capitalism's drive to separate the individual from its class or community while still retaining the power to exploit the social relations established within the communities by the working-class. As Engels (1845) says, it is to the benefit of capitalism that human beings treat other human beings as objects of exploitation so that: 
[p]eople regard each other only as useful objects; each exploits the other, and the end of it all is that the stronger treads the weaker under foot; and that the powerful few, the capitalists, seize everything for themselves, while to the weak many, the poor, scarcely a bare existence remains (Engels 1845, 329).

By manipulating the digital means of communication, the dominant medium today, within which new social relations get formed and the existing ones get mediated, capitalism creates digital spaces of alienation (Fuchs 2019b, 148), where capital still dominates but only in a more indirect fashion by utilising the participatory culture of the social media users. This allows capitalism to convert human beings into customers. Engels's (1845) theory regarding the entrapment of the individuals within their narrow private interests through capitalist manoeuvrings also sheds light on the process in which an already existing communicative framework makes it not only easier but also attractive to the working-classes to engage in social media commerce, and not focus on cooperative living.

The brutal indifference, the unfeeling isolation of each in his private interest, becomes the more repellent and offensive, the more these individuals are crowded together, within a limited space. And, however much one may be aware that this isolation of the individual, this narrow self-seeking, is the fundamental principle of our society everywhere, it is nowhere so shamelessly barefaced, so self-conscious as just here in the crowding of the great city. The dissolution of mankind into monads, of which each one has a separate principle, the world of atoms, is here carried out to its utmost extreme. Hence it comes, too, that the social war, the war of each against all, is here openly declared (Engels 1845, 329).

Social media commerce makes "selling", as an activity of one exploiting the other, a normal routinised activity as some of the responses which were received during the course of the present study exhibit:

- "It makes it easier and encourages me to sell more. I probably would not sell the items if I did not have Facebook".

- "If Facebook did not exist, I would have donated my stuff. Facebook definitely makes things easier especially for someone like me with a busy schedule".

This normalisation also has a relationship with the labour process theory as elaborated upon by Braverman (1998), who talked about how the reduction in the cost of production can only be done through an extreme control over labour. Subsequently, O'Connor (1998) writing about capitalism and its production process, spoke about how advanced capitalism always harbours an interest in commercialising not only the produced commodities but also the production process itself. In other words, in a drive to accumulate more profits, capitalism inevitably attempts to control the dynamics of the relationship existing between labour-power, labour control, the production process and the market. Taking cue from Castells's (2010) argument about the increasing utilisation of ICTs by global monopolies in both production and circulation, it can be said that capitalism has performed both the above-mentioned processes identified by Braverman (1998) and O'Connor (1998) through the application of communication. The commercialisation of the means of communication has not only enabled capitalism to control the labour outside the formal production process but has also successfully allowed it to exploit people with a limited social life by getting them being involved with the society through making 
it easy for them to engage in commercial practices on social media platforms, as one of the interviewees put it,

I think it would be much harder to sell items if FM were removed, as I do not have a large social circle. I'd still be inclined to sell things but would have to find another way, as I find the physical stores very daunting.

Capitalism, by emphasising on social media commerce, in certain ways, has used the power of socialisation to accumulate further profits. It not only aids in transforming people into customers, even from the perspective of other people who are customers themselves but also helps in sustaining the system by temporarily delaying the crisis. It does so by creating a mechanism which ensures that capital does not remain fallow (Mandel 1978; Engels 1843) but keeps on getting invested and circulated. There is a transformation of the entire society into a customer pool, where each individual is a potential customer of not only the monopoly capitalist but also of every other individual, who is again a customer of the same monopoly capitalist. This digitally connected social pool of customers, aided by a rising consumerism (Bauman 2005) transforms human beings into profit bearing machines (Engels 1845), which makes the exchange process smoother and faster. Some of the responses of the interviewees, which can be quoted to be a testimony to the argument, are:

- "People usually just focus on the items and not the seller".

- "It helps that I am invisible and do not have to personally interact with the customer. The entire focus is on the price and negotiation".

The utopian post-capitalist advocacy that digitalisation will lead to an end of capitalism (Mason 2016) do not hold good, when capitalism moves towards extracting surplus value and profits from each and every stage and level of the production process, including the digital components (Staab and Nachtwey 2016). Capitalism as a system recognises, if not explicitly then implicitly, that unless and until, there is a continuous circulation of valorised capital, it is impossible for capital to sustain itself. All societies are spaces that are constructed out of certain shared meanings (Bauman 2001). Because most of the individuals interpret society, both as a space and as an organisation, in a certain manner, there is a shared and dominant understanding of society. Capitalism, through its promotion of social media commerce, attempts to alter this very social understanding of the social space to satisfy its need for the circulation of capital which ultimately increases the value of capital. The only way to achieve this, while keeping the wages down and maintaining the class distinctions brought forward by distribution (Engels 1878), is by encouraging and/or coercing the working-classes to start putting a value on their properties as Engels (1887) had described to be the case of Germany in the preface to the second edition of his "The Housing Question" (1872):

For "[b]ourgeois and petty-bourgeois socialism [...] strongly represented in Germany[...] wish[es] to turn the workers into owners of their dwellings [...] this is a point which has been shown in a very peculiar light by the industrial development of Germany during the past twenty years. In no other country do there exist so many wage workers who own not only their own dwellings but also a garden or field as well [...] With the introduction of machinery all this was altered. Prices were now determined by the machine-made product, and the wage of the domestic industrial worker fell with this price. However, the worker had to accept it or look for other work, and he could not do that without becoming a 
proletarian, that is without giving up his little house garden and field, whether his own property or held by him as tenant. Only in the rarest cases was he ready to do this (Engels 1887, 427-430).

This process ensured that the social mobility of the working-class remains restricted (Engels 1845) because of its restricted exchange relations with its own class, the value generated by which can be accumulated as profits wholly by the capitalists again. The exchange value on the working-class properties, thus, only serve as mere temporal anomalies, which are necessary to facilitate further accumulation. Digitalisation, in this regard, makes it easier for capitalism to initiate further exchange within the society, and make the working-classes see their counterparts as objects to be exploited, as customers, rather than their fellow workers (Engels 1872).

\section{Conclusion}

Engels (1843), like Mandel (1978), noted that stagnant capital cannot generate any surplus value. It was only the capital in circulation which allows capital to continuously valorise itself, in the process generating profits. Under digital capitalism, technological advancements serve the purpose of further valorising the already existing value (Hall and Stahl 2012), and social media commerce plays an important part in this process because it allows capitalism to exploit the rising productive capacities of the workingclass, which had made it possible to produce enough for the society (Engels 1872). The primary aim of the capitalist system, however, is not mere production, but rather the generation of profits and surplus value through production. It aims to do that by altering the relation between living and dead labour in such a way that the latter dominates the former (Tronti 2019; Marx 1867). Social media commerce allows capitalism to create a system of successive consumption, which through the successive and continuous exploitation of dead labour, creates the basis for further accumulation within contemporary capitalism. The valorisation of capital within social media commerce, however, does not only occur through the exploitation of dead labour but also by exploiting the digital and living labour performed by social media users in communicating and circulating the commodity within the society. This continuous valorisation under digital capitalism occurs through an exploitation of communicative technological systems and constitutes, in Negri's (2003) words, a real subsumption of the entire society by capitalism. With the coming of this real subsumption, there has occurred, a possibility of complete blurring of the differences between personal and private properties, which has in turn, resulted in the conversion of all use values to exchange values explicitly and universally.

Although independent property has been historically analysed as being the foundation upon which socio-political stability is built on, under capitalism the individual property of the working-class is the mere ownership of the means of consumption (O'Connor 1984, 17-19). The preceding sections have described how the digital ecosystem is integrally related with the overall capitalist accumulation processes outside digital spaces. This relation is mediated by a web dominated by economic crisis, consumerism, and the constant need of capitalism to produce for production's sake. It has been shown in this paper that the Internet and the activities which occur therein are not something that is completely alienated from the physical world (Jurgenson 2012), but rather are informed and influenced by the wider society.

The relationship between production and exchange is such that without exchange, production can happen but not vice versa (Engels 1878). Capitalism, infested with the 
desire to produce in order to accumulate profits, thus, is in a continuous need for generating improved means of exchange and distribution within the society. These new means of distribution, again, as Engels rightly notes, usually face a strong resistance from the established ones. By initiating commerce through popular social media platforms, digital capitalism countered the resistance from the old modes of distribution through the immense participation of the people and by devising a process in which even the old modes keep on accumulating profits, partially at least, as well. In commercialising communication technologies and using them as a means of production (Fuchs 2020), capitalism has transformed communication into a medium to generate profits (Grohmann 2016).

Utilising the argument from Staab and Nachtwey (2016) against those of Mason (2016), Facebook, a free service (Fuchs 2019a), can be said to have demonstrated that the element of lower marginal costs is only a temporary hindrance to the monopolies and they can still accumulate profits, digitally, physically or through a combination of both, by maintaining the circulation cycle of capital. Social media commerce exhibits that the petty bourgeois utopia of turning every worker into a small capitalist by providing property rights, which Engels (1872) had critiqued, still stands as an unrealistic utopia. Engels's $(1892 ; 1872 ; 1845)$ arguments that private property can never be the basis of liberation but only of domination find relevance when one analyses the reasons for which the working-class get engaged within social media commerce, which are almost always related to the existing social crisis, either materialistically or physiologically. The ownership and circulation of personal properties as commodities through social media commerce today constitute an important part of the exploitative structure of capitalism, the analysis of which is highly important within digital capitalism (Fuchs 2018). In this regard, Engels (1887) remains highly relevant as he had noted long ago:

[t] he ownership of the house, garden and field, and security of tenure in the dwelling-place is becoming today, [...] not only the worst hindrance to the worker, but the greatest misfortune of the whole working class; the basis for an unexampled depression of wages below their normal level (Engels 1887, 431).

The socio-economic crisis does not allow the working-class to utilise the full use value of their properties and put it back into the market thus allowing the commodity to keep on generating exchange value. The temporary monetary gains, when invested again, in the purchase of commodities, leads to an accumulation of capital which becomes the living embodiment of the dead labour infused within not only the commodity itself but also of the many "hands" which circulated it. This scenario also bears testimony to Engels's (1872) point that the ownership of property by the working-class, on its own, neither improves the conditions of the working-class nor automatically results in class mobility. Engels $(1872 ; 1845)$ directs one to think that it is the entire social whole which determines whether the ownership of any property can be indeed progressive in nature. In other words, as long as capital dominates the working class as an alien force (Marx 1867), the potential of the working-class ownership of properties as an emancipatory force remains abysmally low.

Social media commerce utilises the participatory culture within social media, controlled by the monopolies (Fuchs 2014c), for profit-accumulation and valorisation of already existing capital within the society. Since social media is an important part of that communicative paradigm within digital capitalism, Fuchs (2014c) argument about the necessity of rethinking the simplistic models of participation which almost always place social media as a liberatory force within contemporary capitalism stand as an 
important and vital point. Fuchs (2014c) rightly states that true participation enables human beings "to be part of the decisions and to govern and control the structures that affect them" (Fuchs 2014c, 57). Ownership of personal property by the working-class as Engels $(1872 ; 1845)$ had mentioned, does not hold any revolutionary potential as long as capitalism successfully initiates the commercial exchange of those properties by controlling the social dynamics, both economically and culturally, as a whole. Social media commerce functions through converting working-class property into commodities, the commercial exchange of which leads to further profit-accumulation for the capitalist class because the monetary inflow of capital generated by the working-class seller through social media commerce gets diverted to either the consumption of further commodities or, as a response to crisis, towards production and circulation. In this context, social media makes the capital accumulation process smoother by aiding the working-class in generating monetary income so that capitalism can continue to realise the full surplus value and exploit the complete labour-power available in society. This exploitative cycle of capitalism can only be resisted by rupturing the alienated digital spaces (Fuchs 2019b) through a socio-political struggle against the entire capitalist system itself, which, in turn, can re-establish a humane society, free from the consumerism and commodification, which digital capitalism, or capitalism in general, establishes in the society. This humane society can finally be an antidote to the crisis that capitalism generates.

I assert that thousands of industrious and worthy people - far worthier and more to be respected than the rich [...] do find themselves in a condition unworthy of human beings; and that every proletarian, everyone, without exception, is exposed to a similar fate without any fault of his own and in spite of every possible effort (Engels 1845, 335).

\section{References}

Bauman, Zygmunt. 2010. 44 Letters from a Liquid Modern World. Cambridge: Polity.

Bauman, Zygmunt. 2005. Liquid Life. Cambridge: Polity.

Bauman, Zygmunt. 2001. The Individualized Society. Cambridge. Polity.

Bauman, Zygmunt. 1999. Liquid Modernity. Cambridge: Polity.

Banaji, Jairus. 2020. A Brief History of Commercial Capitalism. Chicago: Haymarket.

Bell, Daniel. 1974. The Coming of Post-Industrial Society: A Venture in Social Forecasting. London: Heinemann.

Braverman, Harry. 1998. Labor and Monopoly capital: The Degradation of Work in the Twentieth Century. New York: Monthly Review Press.

Briziarelli, Marco. 2014. The Ideological Reproduction: (Free) Labouring and (Social) Working within Digital Landscapes. tripleC: Communication, Capitalism \& Critique. Open Access Journal for a Global Sustainable Information Society 12 (2): 620-631.

Burston, Jonathan, Nick Dyer-Witheford, and Alison Hearn. 2010. Digital Labour: Workers, Authors, Citizens. Ephemera: Special issue 10 (3-4): 214-539.

Castells, Manuel. 2009. Communication Power. New York: Oxford University Press.

Castells, Manuel. 1996/2010. The Rise of Network Society. Oxford: Blackwell.

Crawford, Kate. 2012. Four Ways of Listening with an iPhone. In Studying Mobile Media: Cultural Technologies, Mobile Communication, and the iPhone, edited by Larissa Hjorth, Jean Burgess, and Ingrid Richardson, 213-228. London: Routledge.

Engels, Friedrich. 1892. The Origin of the Family, Private Property and the State. In the Light of the Researches by Lewis H. Morgan. In Marx \& Engels Collected Works (MECW) Volume 26, 129-276. London: Lawrence \& Wishart. 
Engels, Friedrich. 1887. Preface to the Second Edition of The Housing Question. In Marx \& Engels Collected Works (MECW) Volume 26, 424-433. London: Lawrence \& Wishart.

Engels, Friedrich. 1878. Anti-Dühring. Herr Eugen Dühring's Revolution in Science. In Marx \& Engels Collected Works (MECW) Volume 25, 5-309. London: Lawrence \& Wishart.

Engels, Friedrich. 1872. The Housing Question. In Marx \& Engels Collected Works (MECW) Volume 23, 317-391. London: Lawrence \& Wishart.

Engels, Friedrich. 1845. The Condition of the Working-class in England. Oxford: In Marx \& Engels Collected Works (MECW) Volume 4, 295-596. London: Lawrence \& Wishart.

Engels, Friedrich. 1843. Outlines of a Critique of Political Economy. In Marx \& Engels Collected Works (MECW) Volume 3, 418-443. London: Lawrence \& Wishart.

Fuchs, Christian. 2021. Social Media: A Critical Introduction. London: Sage. Third edition.

Fuchs, Christian. 2020. Towards a Critical Theory of Communication as Renewal and Update of Marxist Humanism in the Age of Digital Capitalism. Journal for the Theory of Social Behaviour 50 (3): 335-356.

Fuchs, Christian. 2019a. Re-Reading Marx in the Age of Digital Capitalism. London: Pluto Press.

Fuchs, Christian. 2019b. Henri Lefebvre's Theory of the Production of Space and the Critical Theory of Communication. Communication Theory 29 (2): 129-150.

Fuchs, Christian. 2018. Universal Alienation, Formal and Real Subsumption of Society under Capital, Ongoing Primitive Accumulation by Dispossession: Reflections on the

Marx@200-Contributions by David Harvey and Michael Hardt/Toni Negri. tripleC: Communication, Capitalism \& Critique. Open Access Journal for a Global Sustainable Information Society 16 (2): 454-467.

Fuchs, Christian. 2017. Social Media: A Critical Introduction [2nd edition]. London: Sage.

Fuchs, Christian. 2016. Towards Marxian Internet Studies. In Marx in the Age of Digital Capitalism, edited by Christian Fuchs and Vincent Mosco, 22-67. Leiden: Brill.

Fuchs, Christian. 2015. The Digital Labour Theory of Value and Karl Marx in the Age of Facebook, YouTube, Twitter and Weibo. In Reconsidering Value and Labour in the Digital Age, edited by Christian Fuchs and Eran Fisher, 26-41. Basingstoke: Palgrave Macmillan.

Fuchs, Christian. 2014a. Digital Labour and Karl Marx. London: Routledge.

Fuchs, Christian. 2014b. Occupy Media! The Occupy Movement and Social media in Crisis Capitalism. Winchester: Zero Books.

Fuchs, Christian. 2014c. Social Media: A Critical Introduction. London: Sage.

Fuchs, Christian and Vincent Mosco, eds. 2016. Marx in the Age of Digital Capitalism. Leiden: Brill.

Fuchs, Christian and Vincent Mosco. 2012. Introduction: Marx is Back - The Importance of Marxist Theory and Research for Critical Communication Studies Today. tripleC: Communication, Capitalism \& Critique 10 (2): 127-140.

Fuchs, Christian. 2008. Internet and Society: Social Theory in the Information Age. New York: Routledge.

Fuchs, Christian and Sebastian Sevignani. 2013. What Is Digital Labour? What Is Digital Work? What's Their Difference? And Why Do These Questions Matter for Understanding Social Media? tripleC: Communication, Capitalism \& Critique 11 (2): 237-293.

Gardiner, Michael. 2000. Critiques of Everyday Life. London: Routledge.

Grohmann, Rafael. 2016. Humanist and Materialist Perspectives on Communication: The Work of Alvaro Vieira Pinto. tripleC: Communication, Capitalism \& Critique 14 (2): 438450.

Hall, Richard and Bernd Stahl. 2012. Against Commodification: The University, Cognitive Capitalism and Emergent Technologies. tripleC: Communication, Capitalism \& Critique 10 (2): 184-202.

Hardt, Michael and Antonio Negri. 2009. Commonwealth. London: Penguin.

Hardt, Michael and Antonio Negri. 2004. Multitude. New York: Penguin.

Hardt, Michael and Antonio Negri. 2000. Empire. Cambridge: Harvard University Press. 
Harvey, David. 2006. The Limits to Capital. London: Verso.

Jenkins, Henry. 2008. Convergence Culture. New York: NYU Press.

Jurgenson, Nathan. 2012. When Atoms Meets Bits: Social Media, the Mobile Web and Augmented Revolution. Future Internet 4 (1): 83-99.

Kowalik, Tadeusz. 2014. Rosa Luxemburg: Theory of Accumulation and Imperialism. London: Palgrave.

Lefebvre, Henri. 1991. The Production of Space. London: Basil Blackwell.

Luxemburg, Rosa. 1915. The Accumulation of Capital: An Anti-Critique. Retrieved from https://www.marxists.org/archive/luxemburg/1915/anti-critique/index.htm

Luxemburg, Rosa.1913/2003. The Accumulation of Capital. London: Routledge.

Mandel, Ernest. 1978. The Second Slump. London: New Left Books.

Mandel, Ernest. 1975. Late Capitalism. London: New Left Books.

Marx, Karl. 1894. Capital. Volume III. Marx \& Engels Collected Works (MECW) Volume 37. London: Lawrence \& Wishart.

Marx, Karl. 1867. Capital. Volume I. London: Penguin.

Marx, Karl. 1857/1858. Grundrisse: Foundations of the Critique of Political Economy. London: Penguin.

Marx, Karl. 1844. On the Jewish Question. In Marx \& Engels Collected Works (MECW) Volume 3, 146-174. London: Lawrence \& Wishart.

Marx, Karl and Friedrich Engels. 1848. The Manifesto of the Communist Party. In Marx \& Engels Collected Works (MECW) Volume 6, 477-519. London: Lawrence \& Wishart.

Mason, Paul. 2016. Post Capitalism: A Guide to Our Future. London: Penguin Books.

Mavroudeas, Stavros. 2020. Friedrich Engels and his Contribution to Marxism. Human Geography 13 (2): 187-190.

Mosco, Vincent. 2009. The Political Economy of Communication. 2nd Ed. Los Angeles: SAGE Publications.

Negri, Antonio. 2003. Time for Revolution. London: Bloomsbury Academic.

Negri, Antonio. 1989. The Politics of Subversion. Cambridge: Polity.

Neilson, Tai. 2018. Unions in Digital Labour Studies: A Review of Information Society and Marxist Autonomist Approaches. tripleC: Communication, Capitalism \& Critique 16 (2): 882-900.

O'Connor, James. 1998. Natural Causes. New York: Guilford Press.

O'Connor, James. 1984. Accumulation Crisis. London: Basil Blackwell.

Qiu, Jack Linchuan, Melissa Greg and Kate Crawford. 2014. Circuits of Labour: A Labour Theory of the iPhone Era. tripleC: Communication, Capitalism \& Critique 12 (2): 564-581.

Rigi, Jacob. 2014. Foundations of a Marxist Theory of the Political Economy of Information: Trade Secrets and Intellectual Property, and the Production of Relative Surplus Value and the Extraction of Rent-Tribute. tripleC: Communication, Capitalism \& Critique 12 (2): 909936.

Shippen, Nichole Marie. 2014. Decolonizing Time: Work, Leisure and Freedom. London: Palgrave.

Staab, Philipp and Oliver Nachtwey. 2016. Market and Labour Control in Digital Capitalism. tripleC: Communication, Capitalism \& Critique 14 (2): 457-474.

Terranova, Tiziana. 2000. Free Labour: Producing Culture for the Digital Economy. Social Text 18 (2): 33-58.

Tronti, Mario. 2019. Workers and Capital. London: Verso.

Wiener, Norbert. 1961/1948. Cybernetics or Communication and Control in the Animal and the Machine. Cambridge: MIT Press.

Williams, Raymond. 1980. Culture and Materialism. London: Verso. 


\section{About the Author}

Suddhabrata Deb Roy

Suddhabrata Deb Roy is a PhD Candidate in the Department of Sociology, Gender Studies and Criminology in the University of Otago. He primarily works on Critical Marxist Theory and Feminism. 